RONALDO BARROS DE FREITAS

\title{
CARACTERIZAÇÃO MOLECULAR DE ERITROVÍRUS HUMANO B19 ISOLADOS NA REGIÃO AMAZÔNICA
}

Tese apresentada ao Instituto de Ciências Biomédicas da Universidade de São Paulo, para obtenção do Título de Doutor em Ciências (Microbiologia). 
RONALDO BARROS DE FREITAS

\section{CARACTERIZAÇÃO MOLECULAR DE ERITROVÍRUS HUMANO B19 ISOLADOS NA REGIÃO AMAZÔNICA}

Tese (Doutorado) apresentada ao Instituto de Ciências Biomédicas da Universidade de São Paulo, para obtenção do Título de Doutor em Ciências (Microbiologia).

Área de concentração:

Microbiologia

Orientador: Prof. Dr.

Edison Luiz Durigon 
Serviço de Biblioteca e Informação Biomédica do Instituto de Ciências Biomédicas da Universidade de São Paulo

(c) reprodução total

\begin{abstract}
Freitas-Barros, Ronaldo.
Caracterização Molecular de Eritrovírus Humano B19 Isolados na Região Amazônica / Ronaldo Barros de Freitas. -- São Paulo, 2008.
\end{abstract}

Orientador: Edison Luiz Durigon.

Tese (Doutorado) - Universidade de São Paulo. Instituto de Ciências Biomédicas. Departamento de Microbiologia. Área de concentração: Microbiologia. Linha de pesquisa: Virologia Clínica e Molecular.

Versão do título para o inglês: Molecular characterization of the human erythrovirus B19 in the Amazon region.

Descritores: 1. Eritrovirus B19 2. Manifestações clínicas 3. Análise filogenética 4. Genótipos 1e 3 5. Evolução de eritrovírus 6. Seleção natural I. Durigon, Edison Luiz II. Universidade de São Paulo. Instituto de Ciências Biomédicas. Programa de Pós-Graduação em Microbiologia. III. Título. 


\section{UNIVERSIDADE DE SÃO PAULO \\ INSTITUTO DE CIÊNCIAS BIOMÉDICAS}

Candidato(a)

Titulo da Tese:
Ronaldo Barros de Freitas

Caracterização Molecular de Eritrovírus Humano B19 Isolados na Região Amazônica .

Orientador(a):

Edison Luiz Durigon.

A Comissão Julgadora dos trabalhos de Defesa d : - .. - to Doutorado, em sessão pública realizada a ....? 9 ............................., considerou

(x) Aprovado(a) ( ) Reprovado(a)

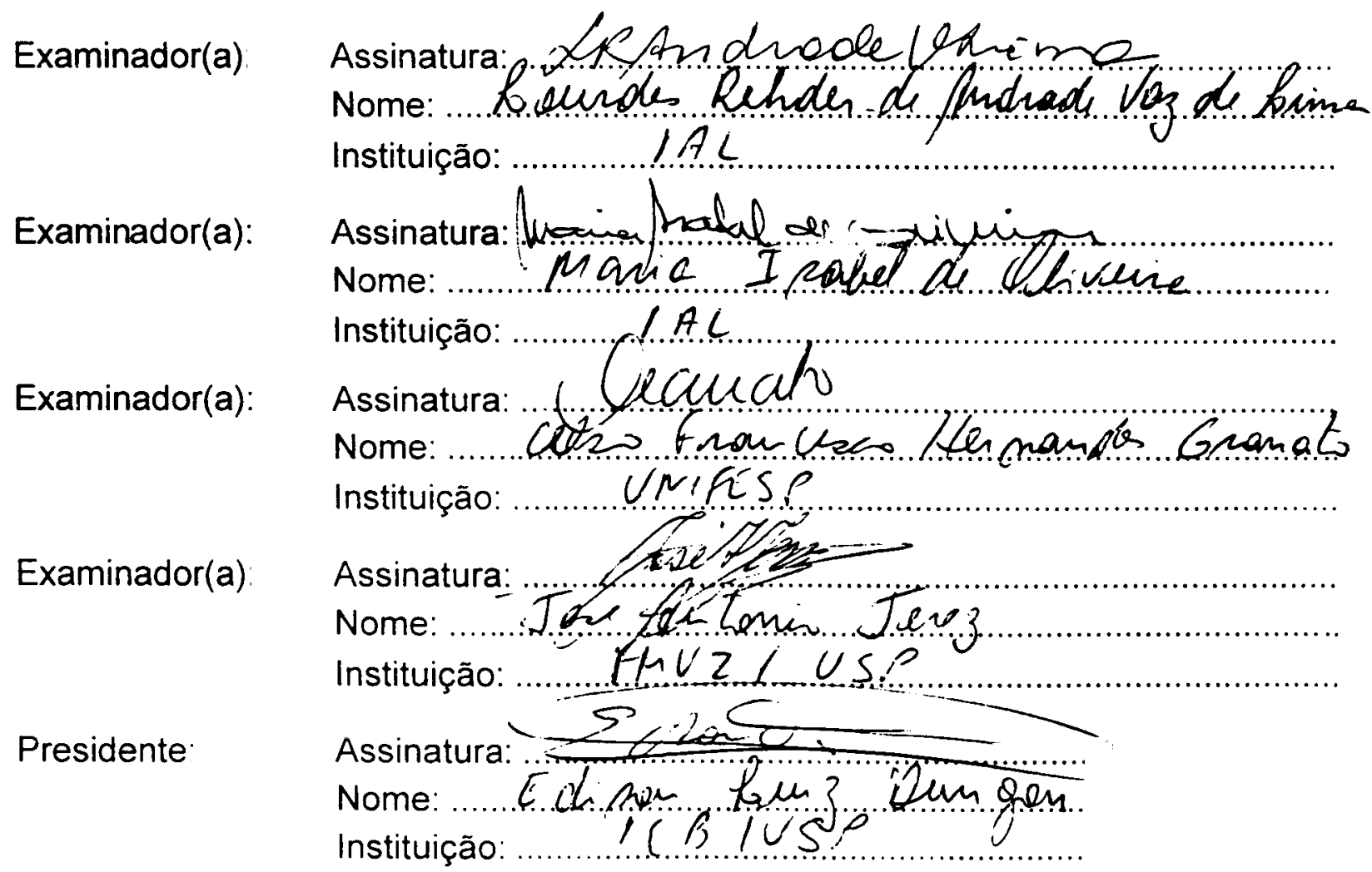


São Paulo, 21 de setembro de 2005.

\section{PARECER 668 / CEP}

Prezado Senhor,

Atendendo sua solicitação, a Comissão de Ética em Pesquisa com Seres Humanos do ICB, em sua qüinquagésima oitava reunião, analisou o projeto de sua responsabilidade intitulado: 'Caracterização molecular de eritrovírus humano isolados na região amazônica".

Informo a V.Sa. que, após análise e discussão, o referido projeto foi aprovado por esta Comissão.

Esclareço a V.Sa. que dentro de 12 meses, relatório do referido projeto deverá ser encaminhado à Secretaria deste CEP.

Atenciosamente,

Prof. Dr. Luiz Vicente Rizzo

Coordenador da Comissão de Ética em

Pesquisas com Seres Humanos - ICB / USP

Ilmo. Sr.

RONALDO BARROS DE FREITAS

Departamento de Microbiologia

Instituto de Ciências Biomédicas 


\section{DEDICATÓRIA}

À minha querida esposa Rute e meus filhos Thaís e Helder pelo amor que demonstraram a minha pessoa. Traduzidos na compreensão, incentivo, dedicação, carinho e pelas inúmeras orações ao nosso Deus ao longo desta jornada.

À meus pais Emanuel e Ana Freitas pelo apoio na minha formação pessoal e profissional à luz de sua fé em Deus e, sobretudo pelos maravilhosos exemplos de humanidade e honestidade. 


\section{AGRADECIMENTOS}

Ao Deus onipotente e onipresente pelo dom da vida, pela manutenção de minha saúde, equilíbrio, serenidade, e, sobretudo, pela dedicação inabalável, fatores essenciais para que pudesse concluir todas as tarefas que envolveram este trabalho.

Ao Prof. Dr. Edison Luiz Durigon, orientador, amigo e mestre pela confiança e constante incentivo, pelas muitas oportunidades geradas ao longo deste trabalho, solução conjunta de inúmeros problemas, pelas informações valiosas e sugestões dadas, e, sobretudo pelo carinho recebido no convívio com seus familiares.

Ao Prof. Dr. Paolo Marinho de Andrade Zanotto e aos colegas da pós-graduação Fernando Lucas Melo e Camila Malta Romano do Instituto de Ciências Biomédicas II (ICB II), Laboratório de Evolução Molecular e Bioinformática da Universidade de São Paulo (USP) por sua valiosa contribuição na análise filogenética.

Aos professores Dr. José Antonio Jerez (USP), Maria Luisa Barbosa (Instituto Adolfo Lutz- IAL), Maria Isabel de Oliveira (IAL), Lourdes Rezder de Andrade Vaz de Lima (IAL) e Eurico de Arruda Neto (USP) por suas sugestões e discussão ao trabalho relacionado à minha qualificação.

Aos colegas de pós-graduação do Laboratório de Virologia Molecular do ICB II da USP pela amizade e apoio constante em todos os momentos que convivemos juntos.

Aos técnicos do Departamento de Microbiologia e particularmente ao do Laboratório de Virologia Molecular ICB II USP pela ajuda no preparo de soluções e reagentes.

Às bibliotecárias do ICB I da USP, em especial a Maria José de Jesus Carvalho, pelo auxilio prestado, pela dedicação e cuidado com o acervo.

Às secretárias do Departamento de Microbiologia do ICB II, Naíde Rodrigues Farripas, Anamaria França Amaral e especialmente à secretaria da pós-graduação, Alice Mitsue Shimabuku pela simpatia e atenção em todos os momentos.

A todos os colegas e docentes do Departamento de Microbiologia do ICB da USP, pela solidariedade e pelo auxilio prestados.

Ao ICB da USP, nas pessoas do Coordenador da pós-graduação Prof. Dr. Mario Julio Ávila Campos e do Chefe do Departamento de Microbiologia Prof. Dr. Luis Carlos de Souza Ferreira. 
Aos doutores Alexandre da Costa Linhares, Maria de Lourdes Contente Gomes, Wyller Alencar de Mello, Yvone Gabbay Mendes, Joana D’Arc Mascarenhas, Olinda Macêdo, Talita Monteiro e Darleise de Sousa Oliveira, pesquisadores da Seção de Virologia do Instituto Evandro Chagas (IEC) por suas valiosas sugestões e ajuda na conclusão do trabalho.

Às secretárias, técnicos e auxiliares de pesquisa, estagiários e consultores que compõe a Seção de Virologia do IEC pela colaboração e suporte técnico durante a execução deste trabalho.

Aos colegas da Biblioteca do IEC e particularmente a Dra. Vânia Barbosa da Cunha Araújo, Nilton César Mendes Pereira e Isabella Maria Almeida Mateus pela normalização e revisão das referências bibliográficas.

Ao IEC, na pessoa da doutora Elisabeth C. de Oliveira Santos, pesquisadora e Diretora, pelo valioso incentivo profissional e apoio constante.

Agradeço a todos que direta ou indiretamente colaboraram para a realização deste trabalho. 


\section{RESUMO}

FREITAS R. B. Caracterização molecular de eritrovírus humano B19 isolados na região amazônica. 2008. 148 f. Tese (Doutorado em Microbiologia) - Instituto de Ciências Biomédicas, Universidade de São Paulo, 2008.

Para avaliar a circulação e freqüência dos genótipos de eritrovírus na região amazônica, foi analisado um total de 487 amostras de soros/plasmas colhidas de pacientes apresentando sintomas e sinais clínicos sugestivos de infecção pelos eritrovírus. O ensaio imunoenzimático (ELISA) foi utilizado para detecção de anticorpos específicos para B19, das classes IgM e IgG, e a reação em cadeia da polimerase/semi-nested PCR; esta empregada na detecção do DNA viral. Das 487 amostras examinadas, 117 (24\%) mostraram a presença do DNA dos eritrovírus, sendo que todas as 117 foram posteriormente seqüenciadas e genotipadas, considerando para análise um fragmento de 476 pb das regiões VP1 e VP2 dos eritrovírus. A maioria dos isolamentos foi classificada como genótipo 1 (91\% das amostras) e 3b (9\% ). Também observamos três diferentes grupos dentro do genótipo 1 (A1, A2, B), bem como a não-associação destas linhagens com manifestação clínica especifica, contudo, inerente ao hospedeiro. Para entender a dinâmica evolucionária do parvovírus humano B19, procuramos analisar a região dos genes VP1 e VP2 em seqüências de Belém (Amazônia), bem como da cidade de São Paulo, Brasil, e globalmente. Nossa análise revelou um padrão notavelmente diferente de mudança evolutiva para estas linhagens introduzidas em Belém, que exibiram uma alta taxa de substituições não-sinônimas, comparadas com as amostras de outras localidades. Assim sendo, propomos que esta diferença está relacionada com a alta prevalência observada em Belém (até 85\%), comparada com a de outras localidades (aproximadamente 50\%), o que impõe uma intensa pressão seletiva. Conseqüentemente, estas linhagens de B19 introduzidas em Belém apresentaram uma elevada taxa de mudanças dos aminoácidos, decorrência da pessão seletiva, gerando reinfecções consecutivas em uma pequena rede de transmissão, metaforicamente comparada a uma "panela de pressão evolutiva". Um estudo adicional tem que ser realizado para monitorar a circulação de eritrovírus na região amazônica, incluindo a possível emergência do genótipo 2.

Palavras-chaves: Eritrovírus B19; Manifestações clínicas; Análise filogenética; Genótipos 1 e 3; Evolução de eritrovírus; Seleção natural 


\begin{abstract}
FREITAS R. B. Molecular characterization of the human erythrovirus B19 isolated in the Amazon region 2008. 148 f. Ph.D thesis (Microbiology) - Instituto de Ciências Biomédicas, Universidade de São Paulo, São Paulo, 2008.
\end{abstract}

To assess the circulation and relative frequency of erythrovirus genotypes in clinical samples from patients living in the Amazon region we screened a total of 487 samples from patients suffering from different clinical manifestations suggestive of erythrovirus infections. An enzyme-linked immunosorbent assay (ELISA) was used to detect B19-specific IgM and IgG antibodies and polymerase chain reaction/ semi-nested PCR for viral DNA detection. Of the 487 samples 117 (24\%) were positive for the erythrovirus DNA and all 117 isolates were sequenced and genotyped analyzing a fragment of 476 bp of VP1 and VP2 gene sequences of the erythrovirus. The majority of isolates was classified as genotype 1 (91\% of the samples) and $3 \mathrm{~b}$ (9\% of the samples). We also reported three different clusters (A1, A2, B) within genotype 1 and no association of these B19 lineages with specific clinical illnesses but seemed inherent to the host. To understand the evolutionary dynamics of human parvovirus B19 we analyzed VP1 and VP2 gene sequences of B19 from Belém (Amazon), the city of São Paulo, Brazil and globally. Our analysis revealed a strikingly different pattern of evolutionary change for those viral lineages introduced into Belém, which exhibited a higher rate of nonsynonymous substitutions compared to those viruses sampled from other locations. We propose that such a difference is due to the high prevalence of B19 in Belém (up to 85\%), as compared to other locations (prevalence of approximately 50\%), which imposes a more intense selection pressure. Hence, those B19 lineages introduced into Belém experienced an elevated rate of amino acid change, driven by positive selection, in order to generate serial reinfections in a small web of transmission, which can metaphorically be thought of as an evolutionary "pressure pan". A further study has to be done to monitor the occurrence of erythrovirus genotypes in the Amazon region, including the possible emergence of genotype 2.

Key-words: Erythrovirus B19; Clinical manifestations; Phylogenetic analysis; Genotypes 1 and 3; Erythrovirus evolution; Natural selection. 


\section{LISTA DE ILUSTRAÇÕES}

Figura 1. Imunomicroscopia eletrônica do parvovírus humano B19 a partir de amostra clínica originada do IEC-SVS, 1988 (foto gentilmente cedida por Mrs. Mary Jenkins, Regional Vírus Laboratory, Inglaterra)........................................... 26

Figura 2. Organização genômica e mapa de transcrição do parvovírus humano B19. A proteína não estrutural NS1 é gerada a partir de um transcrito obtido do lado esquerdo do genoma viral. As proteínas estruturais VP1 e VP2 são provenientes de transcritos localizados no lado direito do genoma, onde se sobrepõem em uma mesma "ORF” (Reproduzido a partir da fonte: Astell et al., 1997)

Figura 3. Representação esquemaática do ciclo biológico do parvovírus B19 com replicação viral dentro da célula hospedeira (fase $\mathrm{S}$ de mitose celular). Fonte: adaptado a partir de Young, N. S. Fields Virology, 1996

Figura 4. Representação esquemática dos eventos virológicos, hematológicos e clínicos da infecção pelo B19 em voluntários humanos sadios. (Fonte: Heegaard e Brown, 2002)

Figura 5. Esquema do genoma viral, emparelhamento dos primers. Os genes estão identificados de acordo com a proteína que codificam e estão listados logo abaixo do esquema do genoma viral.

Figura 6. Arranjo filogenético mostrando a distribuição de genótipos (G1 e G3) em três diferentes grupos, de acordo com o tipo de manifestação clínica, a partir de amostras de DNA positivas, detectadas em pacientes da Amazônia no período de 1995 - 2005.

Figura 7. Árvore Maximum a posteriori (MAP) para 133 sequências da região comum parcial VP1/VP2 (476pb) do parvovírus humano B19.

Figura 8. Comparação da distância genética nas $1^{\mathrm{a}}, 2^{\mathrm{a}}$ e $3^{\mathrm{a}}$ posições do códon versus a distância genética total, entre regiões comuns VP1/VP2 de parvovírus humanos B19. As linhas de regressão indicam que as sequências de Belém.... 


\section{LISTA DE TABELAS}

Tabela 1. Descrição dos primers utilizados para as reações de PCR e Nested-PCR, locação de cada um na sequência de DNA, região e tamanho do produto amplificado (Erdman et al., 1996)

Tabela 2. Detecção do "status" sorológico e detecção de ácido nucléico viral em amostras de pacientes da região amazônica infectados pelos eritrovírus, distribuídos por grupo clínico e faixa etária, no período de 1995 - 2005.

Tabela 3. Distribuição de genótipos (G1 e G3) de acordo com o grupo clínico e faixa etária, a partir de amostras DNA positivas de pacientes da região amazônica infectados pelos eritrovírus no período de 1995 - 2005

Tabela 4. Estimativa Bayesiana da dinâmica de população e parâmetros evolucionários para B19 em amostras do mundo (Cosmopolitas), Belém (Amazônia) e da cidade de São Paulo.

Tabela 5. Estimativa Bayesiana da dinâmica de população e parâmetros evolucionários para a variante D91.1 em amostras do mundo e Belém 


\section{LISTA DE ABREVIATURAS, SIGLAS E SÍMBOLOS}

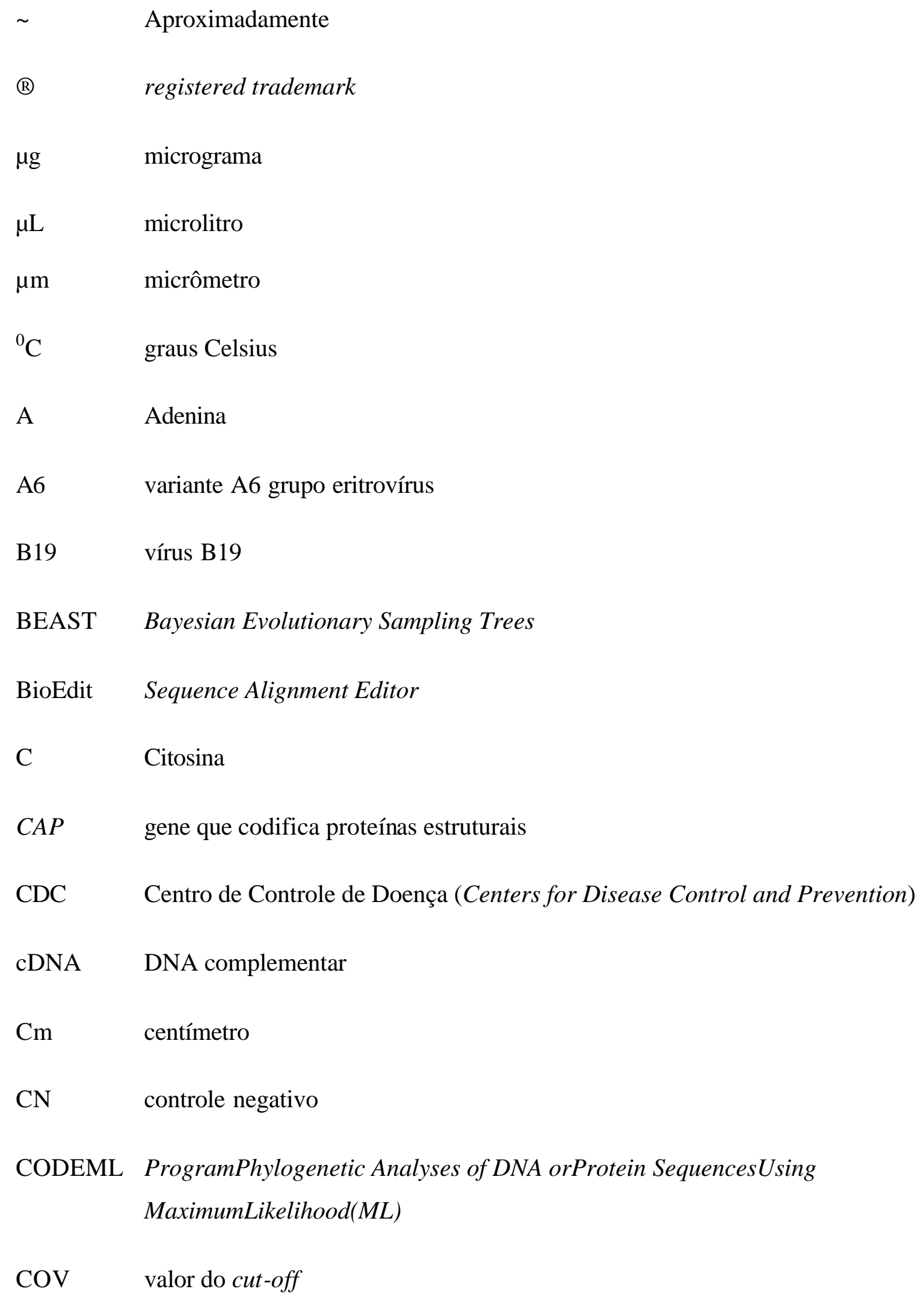


$\mathrm{CP} \quad$ controle positivo

CTL Linfócito T citotóxico

Cut-off valor limite

D91.1 variante D91.1 grupo eritrovírus

dN Substituições não-sinônimas

DNA ácido desoxirribonucléico

DNAse desoxirribonuclease

dNTP desoxinucleotídeo trifosfato (desoxynucleoside triphosphates)

DO densidade ótica

dS Substituições sinônimas

EDTA ácido etilenodiaminotetra acético

EI eritema infeccioso

ELISA ensaio imunoenzimático (enzyme linked immunosorbent assay)

Epi-Info Programa estatístico de análise epidemiológica

g grama

g gravidade

G Guanina

G1 Genótipo 1

G2 Genótipo 2

$\mathrm{H}_{2} \mathrm{SO} 4$ ácido sulfúrico

HCL ácido clorídrico 


\begin{tabular}{|c|c|}
\hline HIV & vírus da imunodeficiência humana (human immunodeficiency virus) \\
\hline HPD & High ProbabilityDensity \\
\hline HyPhy & Hypothesis Testing Using Phylogenies \\
\hline ICB & Instituto de Ciências Biomédicas \\
\hline IEC & Instituto Evandro Chagas \\
\hline $\operatorname{IgG}$ & imunoglobulina $\mathrm{G}$ \\
\hline $\operatorname{IgM}$ & imunoglobulina $\mathrm{M}$ \\
\hline $\mathrm{kDa}$ & kilodalton \\
\hline $\mathrm{L}$ & litro \\
\hline LACEN & Laboratório Central \\
\hline LSC & constante específica do lote \\
\hline M & molar \\
\hline MAP & Maximum a posteriori \\
\hline MCRA & Most Recent Common Ancestor \\
\hline MEGA & Molecular Evolutionary Genetics Analysis \\
\hline $\min$ & minuto \\
\hline $\mathrm{mL}$ & mililitro \\
\hline $\mathrm{mM}$ & milimolar \\
\hline MPRs & Reconstruções mais parcimoniosas \\
\hline mRNA & RNA mensageiro \\
\hline MV & máxima virossimilhança \\
\hline
\end{tabular}




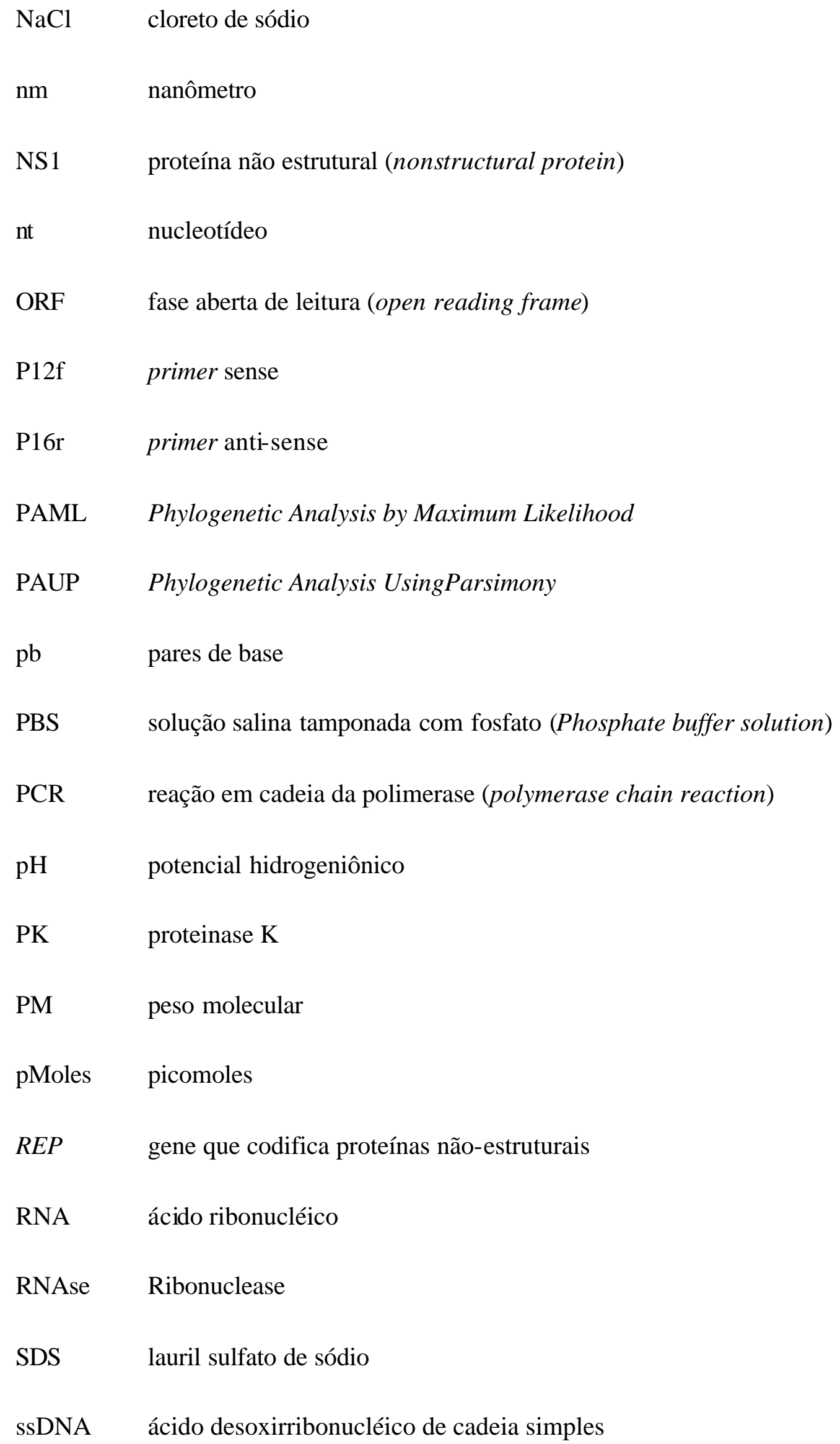


TAC crise aplástica transitória (transient aplastic crisis)

TBE tris-boreto-EDTA

TMB tetrametilbenzidina

TNE tris-sódio-EDTA

Tris hidroximetilaminometano

Tris-HCL tris - ácido clorídrico

U unidade

USP Universidade de São Paulo

UV Ultravioleta

V9 variante V9 grupo eritrovírus

VP1 proteína estrutural de capsídeo (viral protein)

VP2 proteína estrutural de capsídeo (viral protein)

$\lambda \quad L a m b d a$

$\chi^{2} \quad$ qui-quadrado 


\section{SUMÁRIO}

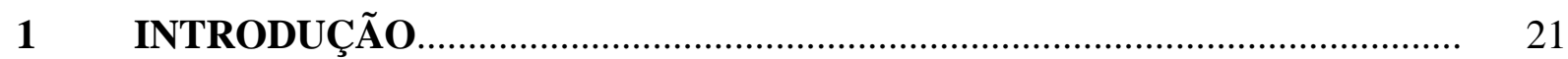

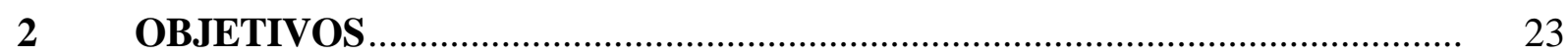

$2.1 \quad$ Objetivo geral............................................................................................ 23

$2.2 \quad$ Objetivos específicos.................................................................................... 23

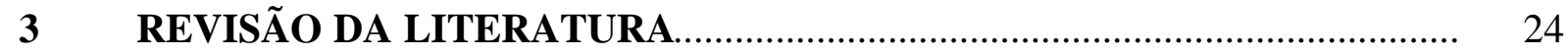

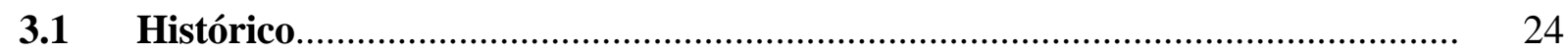

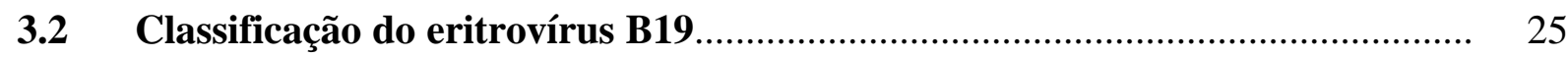

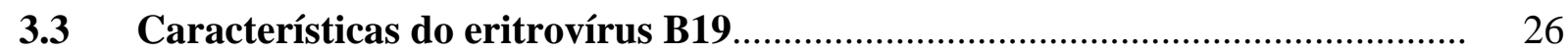

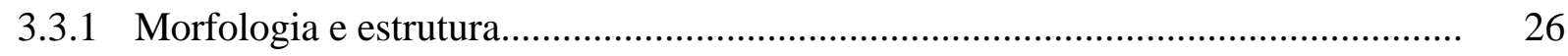

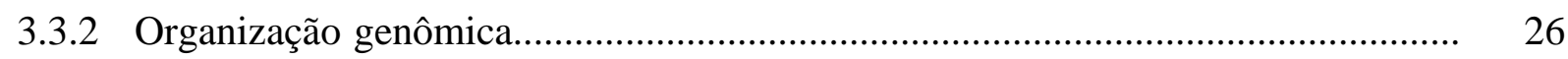

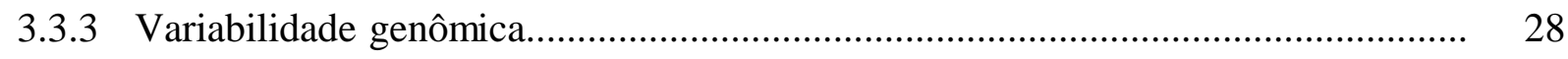

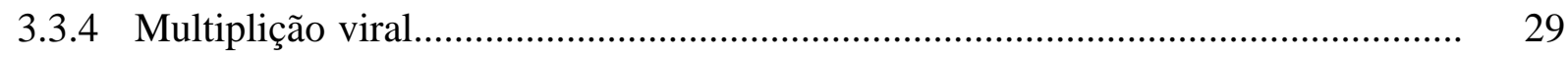

3.3.5 Propagação em cultura celular..................................................................... 31

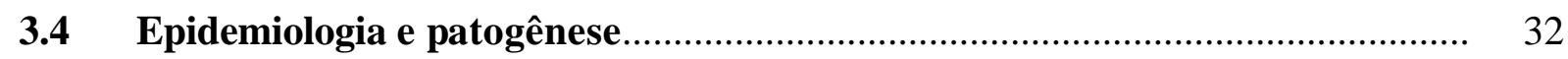

3.4.1 Modelo de transmissão experimental............................................................. 36

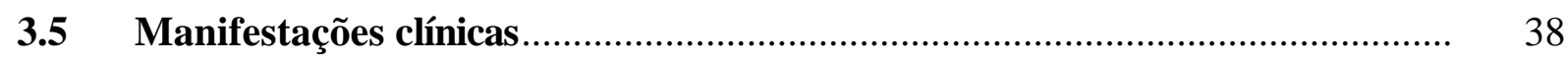

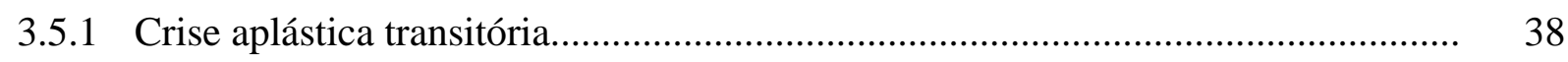

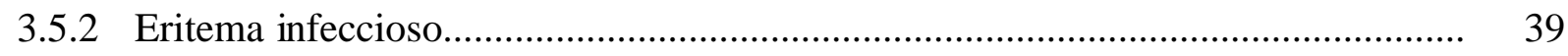

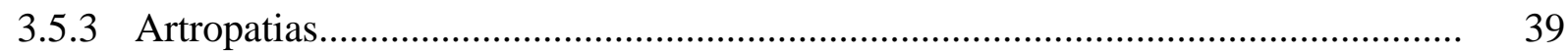

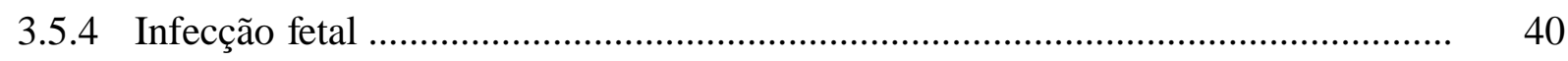

3.5.5 Outras condições clínicas associadas ao eritrovírus B19.................................... 41

3.5.6 Infecção em pacientes imunodeprimidos........................................................... 42

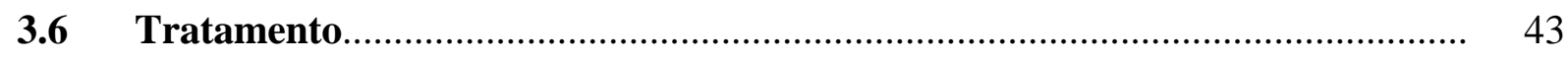

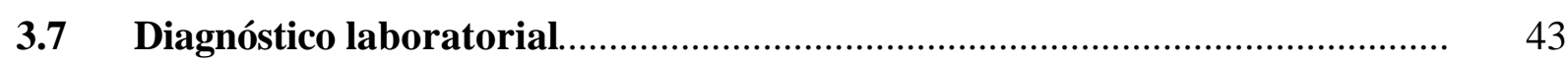

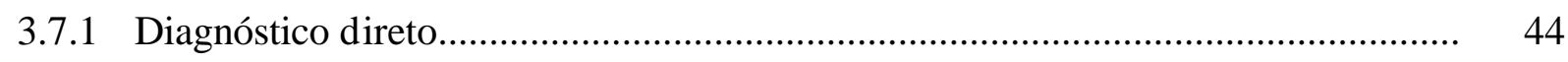




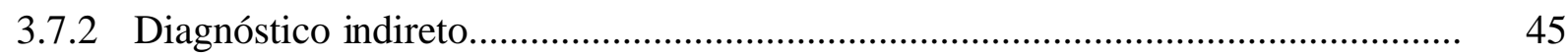

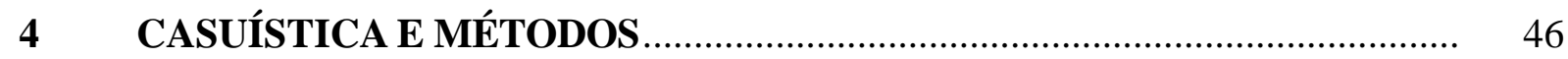

4.1 Pacientes e espécimes biológicos .................................................................... 46

4.2 Teste imunoenzimático para a detecção de anticorpos IgM anti-eritovírus B19 em soro e plasma humano .................................................................... 47

4.2.1 Componentes do kit ................................................................................. 47

4.2.2 Equipamentos utilizados....................................................................... 47

4.2.3 Preparação das amostras............................................................................. 48

4.2.4 Preparação dos reagentes............................................................................ 48

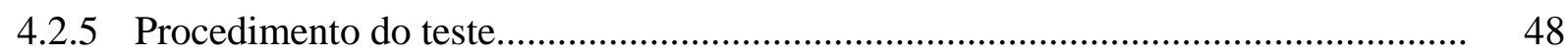

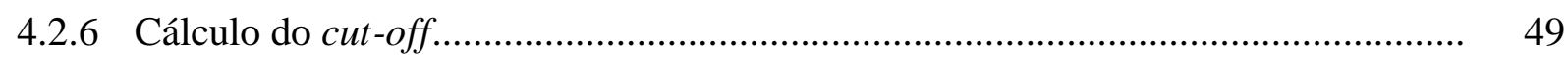

4.2.7 Interpretação dos resultados........................................................................ 49

4.3 Teste imunoenzimático para a detecção de anticorpos IgG anti-eritrovírus B19 em soro e plasma humano .................................................................. 49

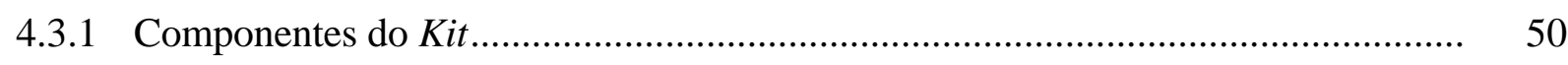

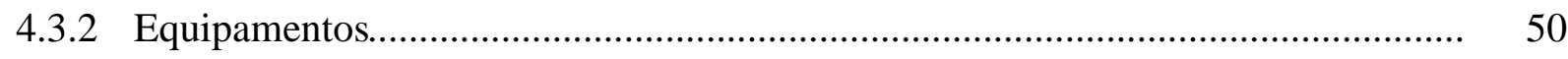

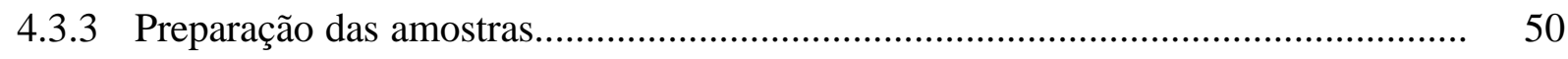

4.3.4 Preparação dos reagentes.......................................................................... 50

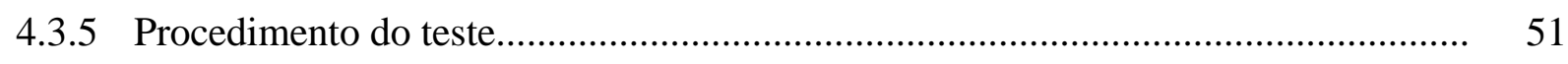

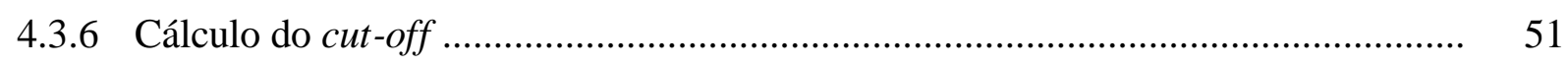

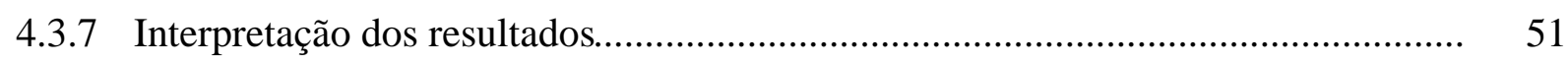

4.4 Extração de DNA utilizando a técnica de fenol-clorofórmio............................. 52

4.4.1 Digestão das amostras de soro e plasma ........................................................ 52

4.4.2 Extração do DNA das amostras de soro............................................................. 52

4.5 Detecção de DNA do eritrovírus B19 pela técnica da reação em cadeia da polimerase (PCR) ............................................................................... 53

4.5.1 Descrição dos oligonucleotídeos (primers) .................................................... 53

4.5.2 Reação de PCR e semi-nested PCR............................................................... 54 
4.5.3 Detecção do produto amplificado por eletroforese............................................ 54

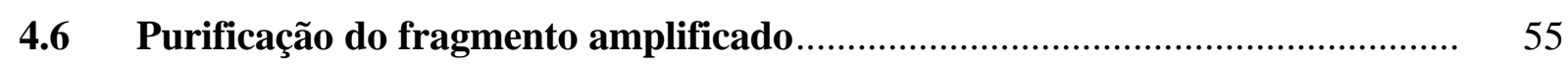

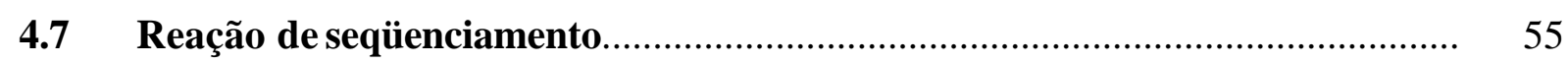

4.8 Precipitação do produto amplificado e sequenciamento................................... 56

4.9 Edição e alinhamento das seqüências da região VP1/VP2 do eritrovírus

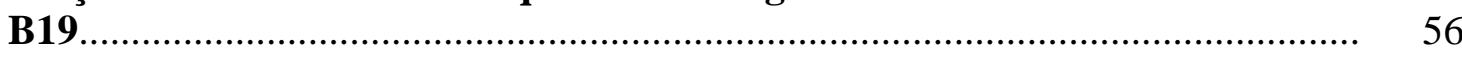

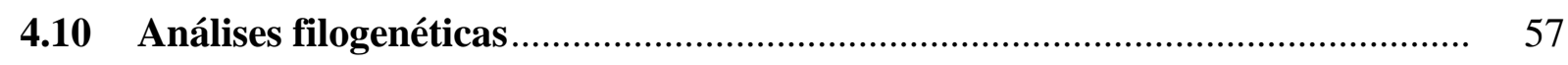

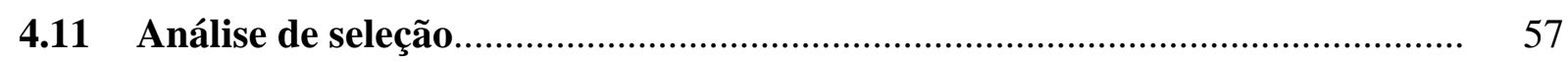

4.12 Reconstrução das mudanças de aminoácidos ............................................... 58

4.13 Análise demográfica relativa ao B19 e D91.1............................................ 58

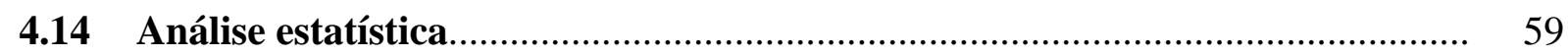

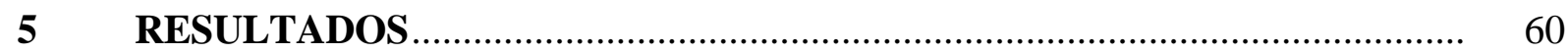

5.1 Detecção do "status” sorológico e do ácido nucléico viral.................................. 60

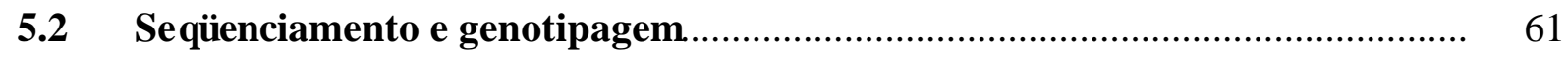

5.3 Relaciona mento filogenético do eritrovírus B19 e variante D91.1................... 61

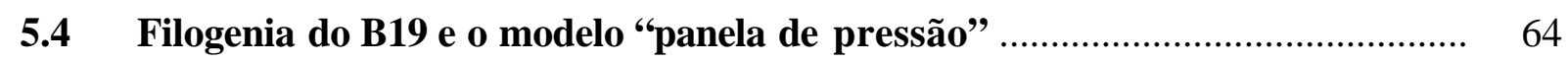

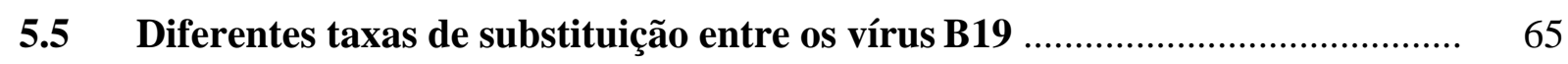

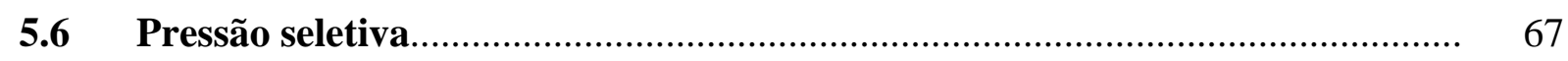

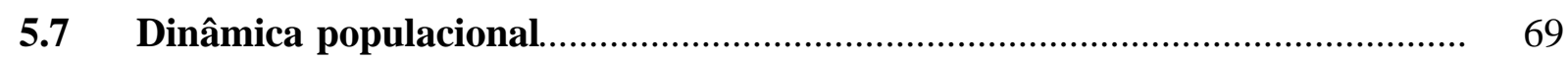

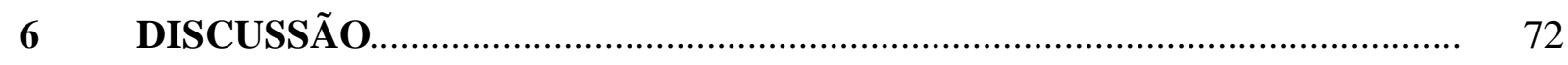

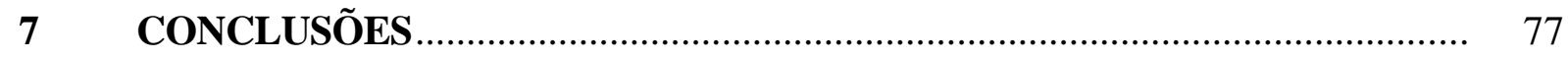

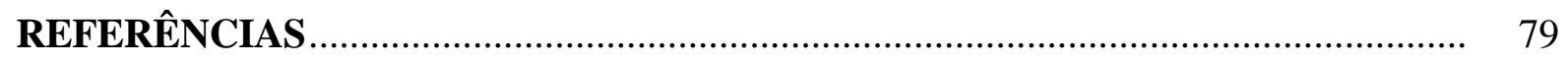

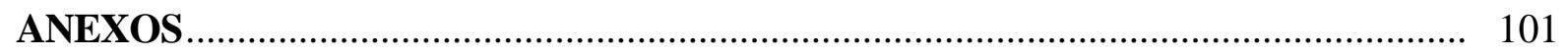




\section{INTRODUÇÃO}

A importância crescente do eritrovírus B19 em relação à patologia humana tem sido traduzida nos inúmeros trabalhos publicados na literatura mundial (ANDERSON M. J. et al., 1987a, 1987b; ANDERSON L. J. et al., 1987; COSSART et al., 1975; CUBEL et al., 1996; OLIVEIRA et al., 1996; PATTISON et al., 1981; WHITE et al., 1985). Apesar da descoberta recente de outros membros do gênero eritrovírus (NGUYEN et al., 1999, 2002), família Parvoviridae, o eritrovírus B19 (antes denominado parvovírus B19) é o único vírus reconhecidamente causador de doença no homem (BERNS; PARRISH, 2007).

No Brasil, a infecção pelo B19 associada ao eritema infeccioso foi primeiramente detectada em bases clínico-laboratoriais na cidade de Belém, Pará (FREITAS et al., 1988; MIRANDA et al., 1989). Posteriormente o vírus foi encontrado em plasma de doador assintomático na cidade do Rio de Janeiro (CRUZ et al., 1989). Estudos pioneiros conduzidos na região Sudeste e Norte do Brasil demonstraram expressiva soropositividade para o B19 em diversos segmentos da população, principalmente entre adolescentes e adultos jovens (FREITAS et al., 1990; NASCIMENTO et al., 1990).

Investigações clínico-epidemiológicas conduzidas na região Norte demonstram que o B19 se configura como um problema emergente de saúde pública. Neste contexto destaca-se o registro de atividade viral expressiva em períodos epidêmicos (1988-1989), intercalados por intervalos (3-4 anos) de reduzida atividade desse agente viral. Esse fato denota um padrão de ocorrência temporal cíclico, postulado por Freitas et al. (1993) na área urbana de Belém. Estudo desenvolvido em comunidades indígenas isoladas da Amazônia mostrou um perfil epidemiológico distinto do observado na área urbana: registrou-se que a maioria dos indígenas dessas comunidades ainda não havia mantido contato com o citado agente viral (FREITAS et al., 1990). Tal situação poderia acarretar a eclosão de surtos epidêmicos nessas comunidades. Estudos realizados na região Sudeste do Brasil demonstraram a presença do B19 em diversos tecidos fetais (NASCIMENTO et al., 1991) e complicações decorrentes da infecção materna como a hidropisia fetal que acomete o concepto principalmente no segundo trimestre da gestação (CUBEL et al., 1996). Investigação realizada em um grupo de gestantes residentes na área urbana de Belém assinala uma baixa incidência (2\%) de infecções recentes pelo B19 na coorte de mulheres grávidas examinadas. Esse fato pode estar relacionado ao período interepidêmico em que foi realizada a investigação, situação em que se observou reduzida atividade viral na área sob investigação 
(FREITAS et al., 1999). Estudo realizado em uma população de doadores de sangue da região Sudeste do Brasil (LISBOA, 1997) encontrou a seguinte proporção: 1/4.325 doadores assintomáticos que no momento da doação estavam infectados, tendo sido encontrado um maior número de doadores assintomáticos com infecção pelo B19 durante primavera. Investigação realizada em um grupo de indivíduos portadores de manifestações articulares (artralgias/artrites) mostrou que a maior incidência ocorre no grupo de mulheres jovens em idade fértil. Tal situação se configura como importante indicador de infecção recente pelo B19 em mulheres gestantes (FREITAS et al., 2002).

Conquanto já seja expressiva a contribuição dessas investigações no tocante às manifestações clínicas e aspectos epidemiológicos relativos às infecções pelo B19 no Brasil, persistem aspectos de relevância inquestionável. Nesse sentido se configuram como imperativos estudos orientados à detecção e caracterização em bases moleculares, do eritrovírus B19, das suas variantes V9/D91.1 e A6/LAli (HOKYNAR et al., 2002; NGUYEN et al., 1999, 2002; SERVANT et al., 2002). Na Amazônia são inexistentes informações oriundas de investigações no campo molecular, envolvendo os citados agentes virais. A possibilidade de detecção e caracterização de novas variantes do B19 na região amazônica permitirá sua classificação em um dos três genótipos propostos por Servant et al. (2002), bem como a realização de estudos filogenéticos e de evolução molecular com outros eritrovírus detectados em diferentes áreas geográficas, previamente cadastrados no banco de dados da Internet "GenBank". 


\section{OBJETIVOS}

\subsection{Objetivo geral}

Caracterização molecular de eritrovírus humano na região amazônica.

\subsection{Objetivos específicos}

a) Detecção de anticorpos específicos para o eritovírus B19 na população sob estudo;

b) Detecção do DNA de eritrovírus humano B19 na população sob estudo;

c) Seqüenciamento dos fragmentos de DNA de eritrovírus B19 detectados;

d) Relacionar as amostras de eritrovírus detectados às diversas condições mórbidas;

e) Análisar do ponto de vista filogenético os eritrovírus detectados na região amazônica. 


\section{REVISÃO DA LITERATURA}

\subsection{Histórico}

O eritrovírus B19 (antes denominado parvovírus) foi descoberto na Inglaterra por Cossart et al. (1975) durante o curso de procedimentos laboratoriais que visavam, primariamente, ao diagnóstico da infecção do vírus da hepatite B. A visualização de partículas virais apresentando morfologia típica ao microscópio eletrônico revelou tratar-se de um vírus da família Parvoviridae (FIELD et al., 1991; SHNEERSON et al., 1980). Posteriormente, estudos de biologia molecular identificaram no vírus a presença de DNA de fita simples com sequiências palindrômicas características desta família (BERNS, 1996). A designação B19, universalmente conhecida, se refere ao rótulo utilizado no frasco que continha a amostra de plasma a partir da qual o vírus foi isolado (ANDERSON, L. J. 1987; YOUNG, 1996).

A primeira associação entre o eritrovírus B19 e doença humana foi registrada por Shneerson et al. (1980). A microscopia eletrônica mostrou partículas virais identificadas morfologicamente como pertencentes à familia Parvoviridae em amostras de soro de dois pacientes com doença febril. A seguir, vários relatos foram publicados na literatura mundial (PATTISON et al., 1981; SERJEANT et al., 1981), relacionando este vírus às chamadas crises aplásticas transitórias (TAC) envolvendo principalmente pacientes portadores de anemia hemolítica crônica. Na Inglaterra, estudos experimentais realizados por Anderson M. J. et al. (1985) comprovaram que o eritrovírus B19 é o agente etiológico do eritema infeccioso (EI). Quadros clínicos de artropatia aguda e crônica foram observados por Reid et al. (1985) e White et al. (1985), bem como de anemia crônica persistente em indivíduos imunocomprometidos (KURTZMAN et al., 1987). A infecção causada pelo eritrovírus B19 durante a gravidez já foi alvo de investigações conduzidas em períodos epidêmicos e não epidêmicos de EI (ANDERSON, L. J. et al., 1988; FREITAS et al., 1999), podendo resultar em hidropisia fetal com morte intra-uterina ou perinatal.

Estudos recentes publicados na literatura científica mundial mencionam outras doenças eventualmente associadas à infecção do eritrovírus B19, pendentes de maior comprovação, envolvendo doenças do miocárdio (MUNRO et al., 2003), lúpus eritematoso sistêmico (HSU et al., 2001; DIAZ et al., 2002), púrpura trombocitopênica idiopática (MARANON; MARTINEZ-MARTINEZ, 2000), doença neurológica (encefalite, meningite, 
neuropatia do plexo braquial) (BARAH et al., 2001; WATANABE et al., 1994) e insuficiência hepática fulminante (DIAZ; COLLAZOS, 2000).

\subsection{Classificação do eritrovírus B19}

Segundo o Comitê Internacional de Taxonomia dos vírus (BERNS; PARRISH, 2007; PRINGLE, 1993) a família Parvoviridae está dividida em duas subfamílias: Parvovirinae (vírus que infectam vertebrados) e Densovirinae (insetos). A Subfamilia Parvovirinae está por sua vez dividida em cinco gêneros: Parvovírus, incluindo os vírus autônomos que se replicam sem a presença de um vírus auxiliar, Dependovírus (ou Adeno Associados), requerendo a presença de um vírus auxiliar para produzir infecção, Eritrovírus, representado até recentemente pelo eritrovírus B19, Amdovírus (vírus identificado em pequeno vertebrado - Visom, um mamífero carnívoro semelhante ao furão) e Betaparvovírus, representado pelo bocavírus (vírus previamente identificados em bovinos e caninos). Esta classificação dos membros deste gênero fundamenta-se em características especiais, relativas à sua propagação e tropismo pelas células precursoras dos eritrócitos (MORTIMER et al., 1983) e seus aspectos moleculares, biológicos e estruturais (DEISS et al., 1990; OZAWA et al., 1986, 1987; ROSENFELD et al., 1992). Densovirinae, que infecta insetos e outros invertebrados, compreendendo quatro gêneros, a saber: densovírus, iteravírus, pefudensovírus e brevidensovírus (BERNS; PARRISH, 2007).

O eritrovírus B19 é o único vírus da família Parvoviridae reconhecidamente capaz de causar doença em seres humanos. No entanto, um crescente número de novos membros desta família tem sido isolado de pacientes com diferentes manifestações clínicas, como o Bocavírus (HBoV), que foi encontrado em células teciduais do trato respiratório (ALLANDER et al., 2005). A par disso, registre-se o denominado PARV4, isolado do plasma de um paciente com síndrome febril, co-infectado pelo vírus da hepatite B (FRYER et al., 2006). Neste particular, investigações de Cohen et al. (2006), Heegaard et al. (2001) e Nguyen et al. $(1999,2002)$ descreveram novas variantes detectadas em soros e amostras de medula óssea de pacientes portadores de anemia aplástica transitória. Estudo conduzido por Schneider et al. (2008) na Alemanha mostrou evidência de que indivíduos podem ser infectados por dois diferentes genótipos do gênero eritrovírus e que o DNA do vírus B19 pode persistir como uma população de distintos genomas. 


\subsection{Características do eritrovírus B19}

\subsubsection{Morfologia e estrutura}

A partícula do eritrovírus B19 possui forma esférica com diâmetro que varia de 18 a $26 \mathrm{~nm}$ (Figura 1) e ausência de envoltório lipoprotéico. O capsídeo apresenta simetria icosaédrica, sendo constituído por 60 capsômeros com 3 a 4 nm de diâmetro. A partícula completa ou virion possui peso molecular de 5,5 a 6,2 x $10^{6}$ Daltons (aproximadamente 50\% de massa viral é constituída de proteínas e o restante de DNA), massa específica em gradiente de cloreto de césio de 1,39 a $1,42 \mathrm{~g} / \mathrm{cm}^{3}$. A partícula vazia ou incompleta, considerada não infecciosa, apresenta peso molecular de 4,2 × $10^{6}$ Daltons, com massa especifica em cloreto de césio de $1,32 \mathrm{~g} / \mathrm{cm}^{3}$. A partícula completa é bastante resistente, mantendo-se estável na faixa de $\mathrm{pH}$ de 3 a 9. É inativada à temperatura de $56^{\circ} \mathrm{C}$ por 60 minutos e quando submetida a tratamento com solventes orgânicos, agentes oxidantes, formalina ou betapropionolactona e a irradiação com raios gama (BERNS, 1996; COHEN et al., 1992; SIEGL et al., 1985).

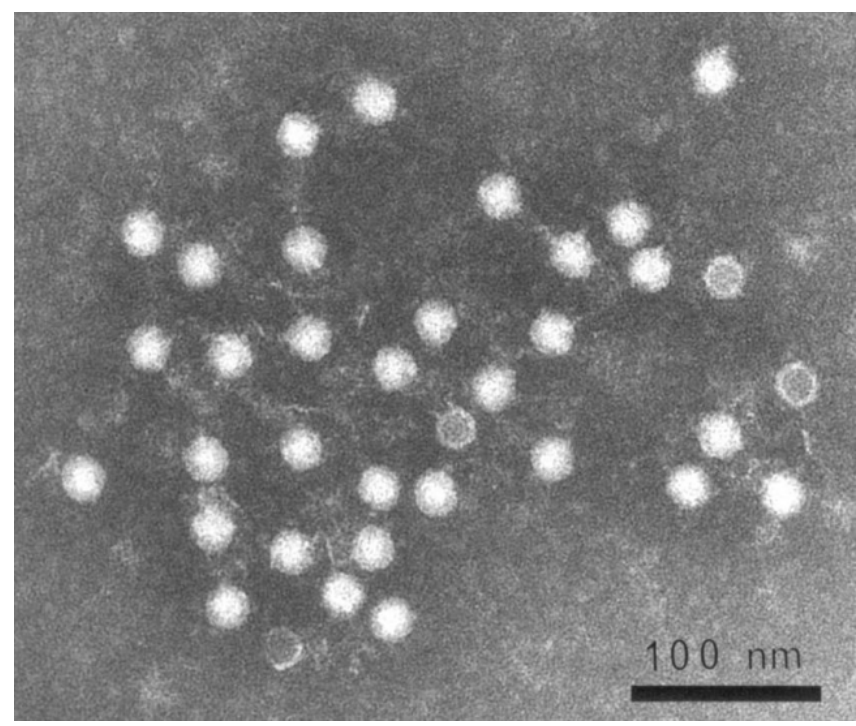

Figura 1 - Imunomicroscopia eletrônica do parvovírus humano B19 a partir de amostra clínica originada do IEC-SVS, 1988 (foto gentilmente cedida por Mrs. Mary Jenkins, Regional Vírus Laboratory, Inglaterra).

\subsubsection{Organização genômica}

O genoma do B19 é constituído por um filamento de DNA linear de fita simples (ssDNA) com polaridades positiva e negativa equivalentes na partícula viral, e peso molecular de 5,5 a 6,2 x $10^{6}$ Daltons. O DNA possui 5.596 nucleotídeos (nt); (44\% G+C) e extremidades com sequiências palindrômicas idênticas. O genoma do B19 apresenta duas regiões de leitura 
(ORFs). As da extremidade direita (ORF2, ORF3, ORF4) - gene CAP - codificam as proteínas estruturais VP1(84 kDa) e VP2 (58 kDa), esta última representando 95\% do capsídeo (ANDERSON L. J. et al., 1990a; COTMORE et al., 1986). A extremidade esquerda (ORF1) gene REP - codifica uma proteína não estrutural NS1. Foi identificada e caracterizada uma família de proteínas com 11-kDa sem função especifica estabelecida na estrutura do B19 (ST AMAND et al., 1993) (Figura 2).

O vírus apresenta um único promotor (p6) responsável pela transcrição em nove mRNAs, todos com início na extremidade 5' do genoma. O primeiro mRNA, único que não sofre processamento pós-transcrição, traduz a proteína NS1, importante na replicação e lise celular (ASTELL, 1990; BERNS, 1996; LUO et al., 1993). A citotoxicidade da NS1 está estritamente relacionada à apoptose, resultando na ativação da caspase 3, que por sua vez pode alterar e degradar proteínas celulares vitais, como enzimas de reparo de DNA, induzindo a morte celular (MOFFATT et al., 1998). A proteína VP1 é caracterizada por um domínio adicional de 227 aminoácidos, na região amino terminal, denominada região única de VPI (VP1u). Desta forma, as sequiências de VP1 e VP2 são idênticas, exceto pela adição dos aminoácidos na estrutura de VP1. A orientação da região VP1u na estrutura do capsídeo é
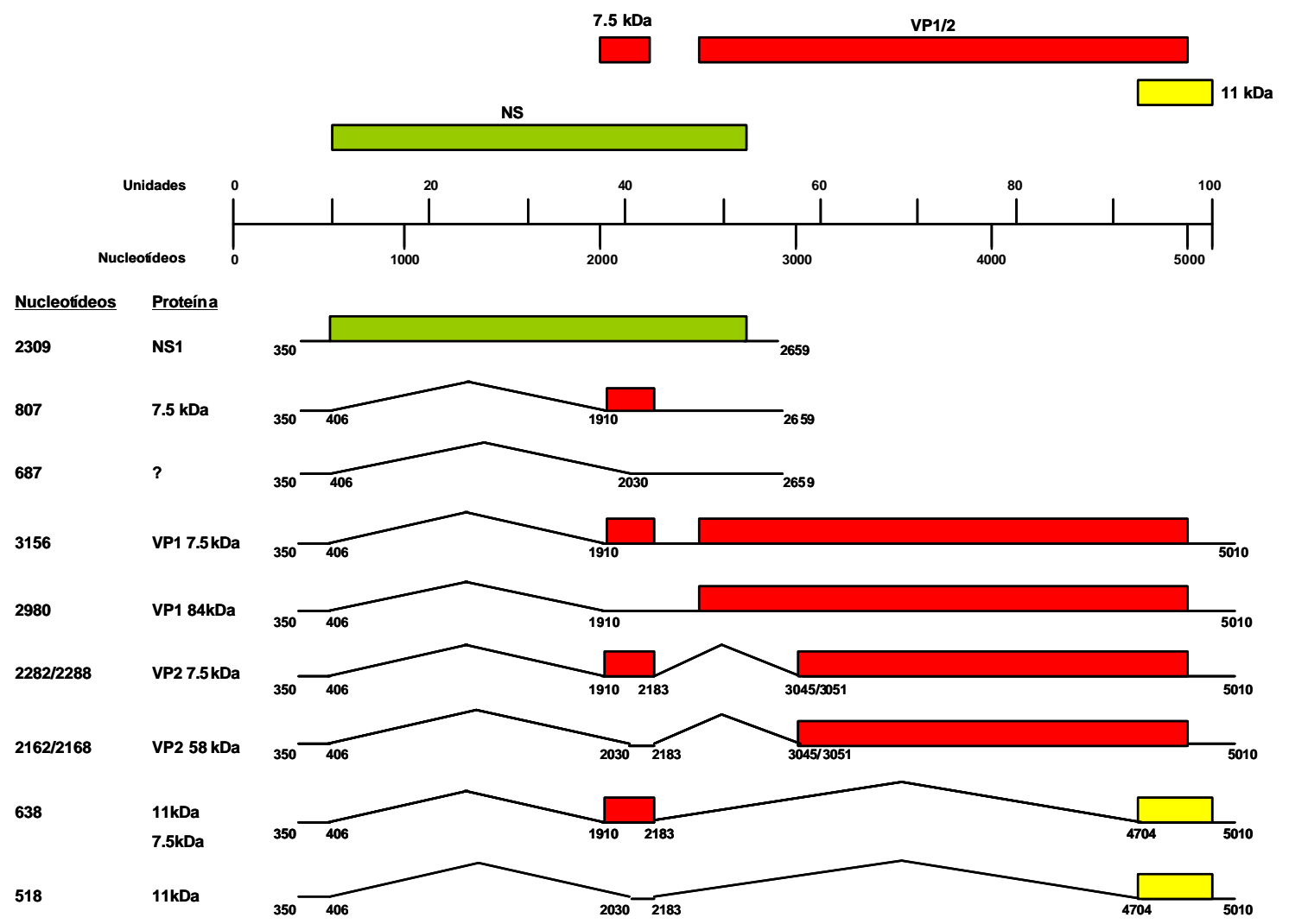

Figura 2- Organização genômica e mapa de transcrição do parvovírus humano B19. A proteína não estrutural NS1 é gerada a partir de um transcrito obtido do lado esquerdo do genoma viral. As proteínas estruturais VP1 e VP2 são provenientes de transcritos localizados no lado direito do genoma, onde se sobrepõem em uma mesma "ORF” (Reproduzido a partir da fonte: Astell et al., 1997). 
desconhecida. Considerando que os anticorpos neutralizantes IgM e IgG produzidos durante o curso da infecção são dirigidos contra epítopos deste domínio, presume-se que VP1u seja exposta na superfície do vírus (BASAL et al., 1993; ROSENFELD et al., 1994). Não obstante a região de VP1u mostrar um grau elevado de variabilidade genômica e de aminoácidos, a conformação deste domínio parece ser bastante estável (HEMAUER et al, 1996; HOKYNAR et al., 2000).

\subsubsection{Variabilidade genômica}

As diferenças nas seqüências nucleotídicas genômicas do eritrovírus B19 podem ser detectadas por técnicas de biologia molecular disponíveis tais como: mapeamento com enzimas de restrição e seqüenciamento de produtos da reação em cadeia da polimerase (PCR), possibilitando estudos sobre a sua evolução, forma de transmissão, distribuição, bem como pesquisas que permitem correlacionar o genótipo às diferentes patologias associadas a este agente viral.

Estudos relacionados ao alinhamento de seqüências nucleotídicas do B19 previamente identificadas, mostraram que estas amostras apresentavam uma baixa diversidade genética, cerca de $1 \%$ a $2 \%$ para toda estrutura genômica. Entretanto, a análise se restringiu a um número reduzido de amostras isoladas (BLUNDELL et al., 1987; SHADE et al., 1986). Os primeiros estudos demonstrando a existência de uma variabilidade genética foram realizados por meio do mapeamento com enzimas de restrição. Observações decorrentes dessas investigações denotam alguns padrões de restrição do B19 encontrados apenas em determinadas áreas geográficas e um mesmo tipo genômico persistindo durante vários anos também circunscritos a regiões específicas (MORI et al., 1987). No Japão, Umene et al. (1990) constataram a circulação de diferentes tipos genômicos em épocas distintas.

Na Itália, Gallinella et al. (1995, 2003) identificaram homologia de apenas 0,61\% entre as diferentes amostras coletadas no período de 1989 a 1994, indicando uma estabilidade genômica do B19. No estudo de Erdman et al. (1996), a análise de seqüências nucleotídicas da região do capsídeo viral (VP1 e VP2) em amostras de uma epidemia em Ohio, Estados Unidos da América, revelou uma diversidade nucleotídica de 0\% a 0,4\%. As amostras isoladas de diferentes áreas geográficas do mundo, em diferentes épocas, associadas com múltiplas manifestações clínicas produzidas pelo B19, mostraram uma variabilidade genética mais elevada (0,5 a 4,0\%), confirmando a existência de diferentes linhagens ou subpopulações 
do eritrovírus B19. Não foi encontrado qualquer padrão genotípico especificamente associado às diversas patologias envolvidas com o B19.

A seqüência gênica responsável pela tradução da proteína NS1 é bem conservada na maioria das amostras isoladas e, portanto, consistente com o papel que desempenha na propagação do vírus. No entanto, as regiões de VP1 e VP2 podem mostrar uma variabilidade gênica um pouco maior, da ordem de $2 \%$ a $3 \%$ (HEMAUER et al., 1996).

No estudo conduzido por Nguyen et al. (1999) foram registrados percentuais de 11-14\% relativos à diversidade genética de duas novas variantes, V9 e A6, com 24 amostras do grupo B19. Note-se que o percentual de divergência verificado nas 24 sequiências obtidas do grupo B19 foi $\leq 6,65 \%$. A variante A6 exibe $88 \%$ de similaridade com o B19 e $92 \%$ frente à V9, comparando-se com as 24 amostras do grupo B19, cuja correspondência dentro do grupo foi de $>98 \%$. Outra investigação conduzida por Heegaard et al. (2002) mostrou baixa prevalência do B19 e ausência da variante V9 em soros pré - e pós - infecção, em amostras de medula óssea colhidas de doadores sadios, utilizando a técnica da reação em cadeia da polimerase.

Estudo de Toan et al. (2006a) dividiu amostras vietnamitas do genótipo 1 em dois subgrupos, B19-1A e B19-1B, em decorrência de sua diversidade acima de 5\%. Além disso, Parsyan et al. (2007) formularam proposta da criação de dois subgrupos distintos, 3a (V9relacionados) e 3b (D91.1-relacionados), dentro do genótipo 3.

\subsubsection{Multiplicação viral}

$\mathrm{O}$ vírus é adsorvido pela célula com auxilio de um globosídeo (antígeno P) e da proteína VP2 (BROWN et al., 1993). O nível de expressão do antígeno P (globo-tetraosilceramida) não se correlaciona com a eficiência da ligação viral, oferecendo maior evidência quanto a existir um co-receptor celular alternativo para entrada do B19 nas células humanas (WEIGEL-KELLY et al., 2001). O antígeno P está presente na superfície das chamadas "células - alvo", como eritrócitos maduros e seus progenitores, megacariócitos, células endoteliais, placentárias, miocárdicas, fetais e hepáticas (BROWN et al., 1993). Nas células com ausência genética do antígeno $\mathrm{P}$ (fenótipo $\mathrm{P}$ ) não há susceptibilidade à infecção (BROWN et al., 1994). Células que se encontram constantemente na fase $\mathrm{S}$ da mitose, como as precursoras da linhagem eritrocitária, localizadas na medula óssea, e as células hepáticas, propiciam a replicação viral. 
A organização genômica, a replicação do DNA e a síntese das proteínas virais são muito similares entre os parvovírus de animais, mas o B19 difere dos demais quanto ao número de promotores, pois ao invés de dois ou três possui apenas um promotor (P6) localizado na extremidade 5' do genoma viral (BERNS, 1996).

A replicação do DNA viral ocorre no núcleo da célula infectada (Figura 3). O B19 necessita de uma ou mais funções geradas durante a fase tardia $S$ ou inicial $G$ do ciclo celular, como as DNA-polimerases (BERNS, 1996; GAREUS et al., 1998; KURTZMAN et al., 1988; MOREY et al., 1992, 1993; YAEGASHI et al., 1989). As seqüências palindrômicas terminais 5' e 3', contendo aproximadamente 330 nucleotídeos, dobram-se sobre si mesmas, formando uma estrutura similar a um grampo (hairpin) que funciona como "iniciador" da polimerização pela DNA-polimerase celular. Nestas regiões de dupla fita tem inicio a replicação, com o estabelecimento de uma cadeia complementar. Posteriormente, estas duplas fitas são clivadas por enzimas, gerando DNA de fita simples (BERNS, 1996; YOUNG, 1996).

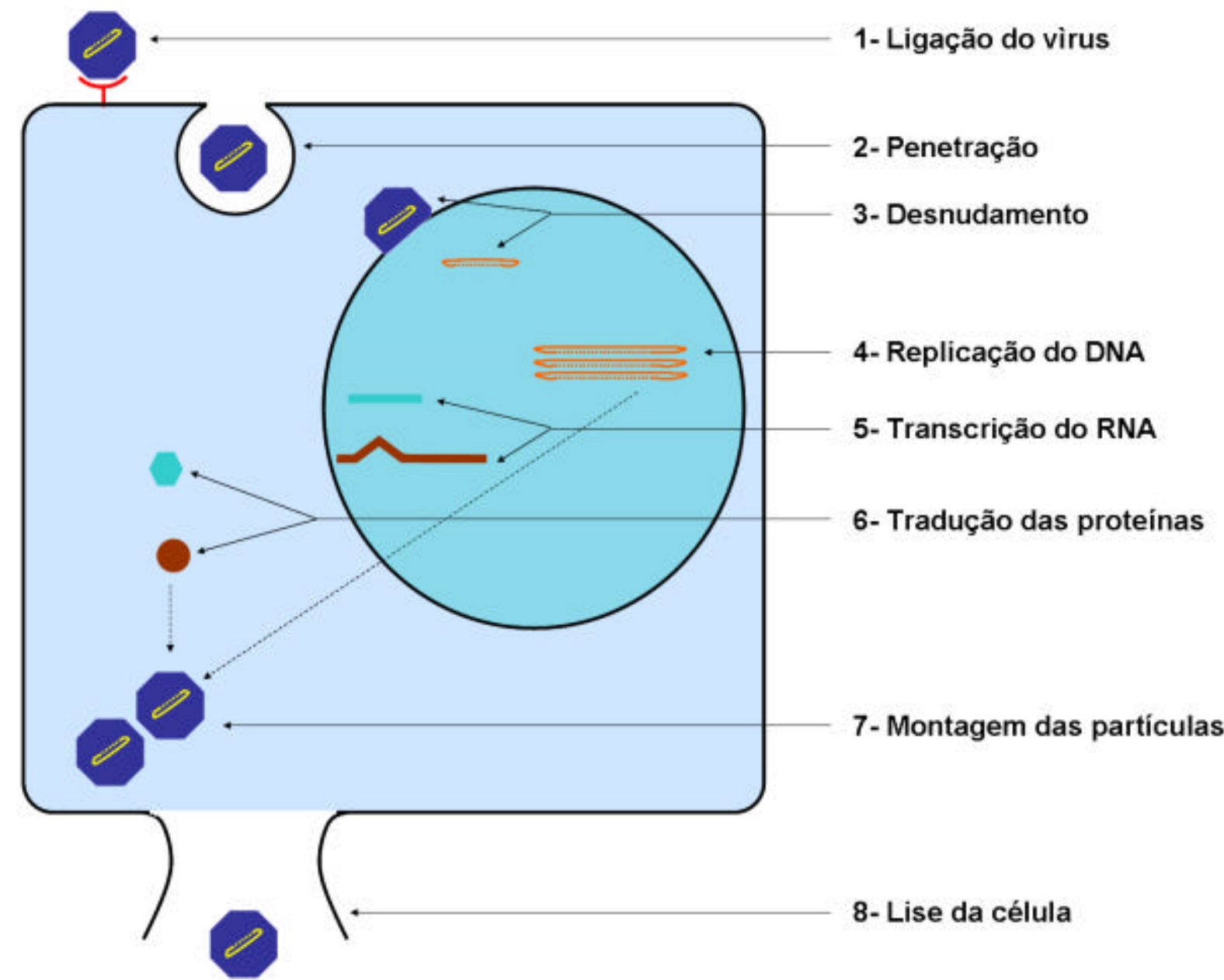

Figura 3 - Representação esquemática do ciclo biológico do parvovírus B19 com replicação viral dentro da célula hospedeira (fase $\mathrm{S}$ de mitose celular). Fonte: adaptado a partir de Young, N. S. Fields Virology, 1996. 
$\mathrm{O}$ processo de transcrição inicia-se no promotor (P6), presente na extremidade esquerda 5' da fita negativa. A partir deste promotor são transcritos 9 mRNAs (RNA mensageiros). Inicialmente ocorre a transcrição para a proteína não estrutural NS1, seguida pela transcrição tardia das proteínas estruturais VP1 e VP2 (BERNS, 1996; GAREUS et al., 1998). Três mRNAs terminam no meio do genoma e utilizam um sinal de poliadenilação não usual. Um mRNA da extremidade esquerda 5' (ORF1), codifica a proteína NS1 e os outros mRNAs da extremidade direita 3' (ORF2, ORF3, ORF4), codificam as proteínas estruturais VP1 e VP2. Os nucleotídeos de 2.444 a 4.786 e de 3.125 a 4.786 codificam respectivamente as proteínas VP1 e VP2. A síntese das proteínas estruturais VP1 e VP2 ocorre no citoplasma da célula e a montagem de novas partículas virais se processa dentro do núcleo com posterior liberação pela lise celular (ANDERSON, L. J. et al., 1987; YOUNG et al., 1984).

O processo de lise celular pode ser observado por microscopia eletrônica em culturas celulares infectadas, onde os principais efeitos observados foram vacuolização do citoplasma, marginação da cromatina nuclear e presença de corpúsculos de inclusão (OZAWA et al., 1986; YOUNG et al., 1984).

\subsubsection{Propagação em cultura celular}

O efeito citopático da infecção pelo B19 em progenitores eritróides se traduz na presença de pronormoblastos gigantes ou "células de lanterna", tanto em in vivo como in vitro. Os pronormoblastos gigantes são células eritróides imaturas com diâmetro de 25 a 32 $\mu \mathrm{m}$ que apresentam alterações associadas à toxidade do vírus tais como: vacuolização citoplasmática com formação de pseudópodes, marginalização da cromatina nuclear, e presença dos corpúsculos de inclusão intranucleares eosinofilicos (CAUL et al., 1988; KODURI et al., 1998; OZAWA et al., 1987; YOUNG et al., 1984).

Recentemente, duas linhagens de células não convencionais de leucemia megacarioblástica, MB-02 e UT-7/Epo têm sido utilizadas para propagar o B19, e podem eventualmente promover isolamento e caracterização biológica deste vírus (MUNSHI et al., 1993; SHIMOMURA et al., 1992), bem como duas linhagens de leucemia eritróide humana JK-1 (TAKAHASHI et al., 1993) e KU812Ep6 (MIYAGAWA et al., 1999).

Estudos de recombinação genética permitiram a inserção de antígenos capsulares do B19 (VP1 e VP2) no genoma de baculovírus, que são capazes de se multiplicar em células de insetos. A expressão destes antígenos VP1 e VP2 pelo genoma do Baculovírus em células 
de insetos propiciou uma renovada fonte de antígeno, comumente usada na concepção das técnicas para o diagnóstico sorológico (KAJIGAYA et al., 1991). Recentemente, uma linhagem celular não eritróide foi utilizada in vitro para propagar o B19. Esse estudo conduzido por Munakata et al. (2006) utilizaram linhagens celulares de monócitos humanos U937.

\subsection{Epidemiologia e patogênese}

As infecções associadas ao eritrovírus B19 têm sido registradas em diferentes países do mundo, tanto naqueles de clima temperado como tropical (ANDERSON, M. J. et al., 1984, 1987a; ADLER et al., 1993; CHORBA et al., 1986). Assinale-se, ne ste contexto, o relato de epidemias de EI em escolas, creches, asilos, hospitais e no âmbito familiar (ANDERSON, M. J. et al., 1984; EVANS et al., 1984; GILLESPIE et al., 1990). Nos países de clima temperado, a incidência de EI exibe nítida variação sazonal com ocorrência ao longo de meses que coincidem com o final do inverno e início da primavera, prolongando-se até o começo do verão. Outro aspecto singular da infecção B19 é representado pelo seu caráter cíclico, com períodos de 3-5 anos em que se denota maior atividade viral e conseqüente eclosão de epidemias de EI ou TAC (ANDERSON, M. J. et al., 1984; CHORBA et al., 1986; PILLAY et al., 1992).

Estudos epidemiológicos conduzidos na Inglaterra por Anderson M. J. et al. (1987a), na vigência de epidemias de El ou TAC associadas ao B19, revelaram que $10 \%$ dos casos ocorreram no grupo etário abaixo dos 5 anos, $70 \%$ em indivíduos entre 5 e 15 anos de idade, e $20 \%$ nos pacientes acima desta faixa etária. A soroprevalência de anticorpos IgG equivalente aos processos mórbidos variou de 2 a $15 \%, 15$ a $60 \%$ e 30 a $60 \%$ nos grupos etários de 1-5, 6-19 e acima de 19 anos, respectivamente.

A freqüência de anticorpos IgG para o B19 registrada em outros países como Estados Unidos, Japão, Chile e Nigéria, envolvendo indivíduos assintomáticos da população variou de $44 \%$ a $80 \%$, mostrando resultados significativamente variáveis (ABARCA et al., 2002; ANDERSON, L. J. et al., 1986; NONOUE et al., 1985).

Durante a fase aguda da doença (período de viremia) o vírus está presente no sangue, saliva e secreção da nasofaringe, podendo ser transmitido pelas vias respiratórias, a partir da administração parenteral de produtos derivados do sangue (SCHMIDT et al., 2001), bem como da mãe para o feto (CHISAKA et al., 2006). A transmissão pelas secreções 
respiratórias decorre do contato direto com o indivíduo que alberga o vírus. Trata-se do meio de transmissão mais eficaz para a propagação do B19 entre os indivíduos suscetíveis da população (SETUBAL et al., 2004; WOOLF et al., 1989). A chance de infecção pelas transfusões sanguíneas e hemoderivados oferece riscos acentuadamente menores, variando de 1 para cada 3.000 a 50.000 amostras. (LISBOA, 1997; McOMISH et al., 1993; TSUJIMURA et al., 1995; YOTO et al., 1995).

Estudo realizado por Foto et al. (1993) não detectou a presença de DNA do eritrovírus B19 em amostras de medula óssea de doadores assintomáticos. É importante ressaltar o número reduzido de espécimes biológicos investigados. Gestantes contaminadas pelo B19 podem eventualmente transmitir o vírus para o feto. O tropismo do vírus por células sanguíneas mitoticamente ativas pode ocasionar a passagem do vírus através do cordão umbilical, comprometendo o tecido fetal (MOREY et al., 1991; MORTIMER et al., 1985). Estudos desenvolvidos na Inglaterra, na vigência de epidemias de EI, estimaram a possibilidade de transmissão transplacentária do B19 em 33\% e, da ordem de $9 \%$ o risco de morte fetal. (ANDERSON, M. J. et al., 1987a, 1987b; HEEGAARD; HORNSLETH, 1995).

Destaque-se a importância epidemiológica da infecção do B19 nos indivíduos portadores de anemia hemolítica crônica apresentando quadro clínico de TAC e em pacientes imunodeprimidos, incapazes de neutralizar o vírus e, portanto, capazes de eliminar este agente viral por longo período. Consequentemente, disseminando-o entre os profissionais de saúde com propagação secundária para indivíduos soronegativos no âmbito familiar (ANDERSON, L. J. et al., 1990a; BELL et al., 1989; DOWELL et al., 1995; KERR et al., 1995).

A infecção assintomática pelo B19 é um achado relativamente comum tanto em crianças como nos adultos. Aproximadamente $25 \%$ das pessoas infectadas não se lembram de sintomas específicos (WOOLF et al., 1989) e menos da metade das mulheres IgM-positivas apresentaram manifestações cutâneas eruptivas ou artralgias (CARTTER et al., 1991). A presença de doadores de sangue assintomáticos que se encontravam na fase virêmica no momento da doação foi registrada por McOmish et al. (1993) durante um estudo realizado na Escócia.

No Brasil, o primeiro registro de EI associado à infecção do B19 foi estabelecido por Freitas et al. (1988) e Miranda et al. (1989) durante um surto epidêmico desta doença em Belém do Pará. Outro estudo pioneiro foi realizado por Cruz et al. (1989) que identificaram a presença do B19 em plasma oriundo de doadores assintomáticos de sangue na cidade do Rio de Janeiro. Estudo conduzido por Linhares et al. (1991) na área urbana de Belém indicou uma 
possível sazonalidade quanto à infecção do eritrovírus B19 em região de clima tropical. Essas observações, decorrentes de um período epidêmico (1988-1989), mostraram que significativa parcela $(75 \%)$ dos diagnósticos realizados em bases clínicas se concentrou no período de junho a outubro, portanto, ao longo dos meses de menor pluviosidade. A periodicidade das epidemias de EI relacionadas à infecção pelo eritrovírus B19 foi registrada por Freitas et al. (1993, 2002). Intervalos de maior ou menor atividade viral ( 3-5 anos) foram observados, o que denota uma circulação endêmica deste agente viral entre indivíduos susceptíveis da área urbana de Belém, Pará.

Estudos soroepidemiológicos realizados por Freitas et al. (1990) e Nascimento et al. (1990) nas áreas urbanas de Belém e Rio de Janeiro encontraram taxas de prevalência global da ordem de $43 \%$ e $72 \%$, respectivamente. Achados pertinentes às investigações soroepidemiológicas conduzidas por Freitas et al. (1990) em comunidades indígenas isoladas da região amazônica, mostraram uma freqüência de positividade quatro vezes menor (4,710,7\%) que a registrada para a zona urbana de Belém do Pará. Estudo desenvolvido por Freitas et al. (2002) confirmou essa atividade endêmica do eritrovírus B19 em amostragem mais ampla constituída por indivíduos portadores de manifestações articulares na cidade de Belém, caracterizada por períodos de alta e baixa atividade viral com intervalos que variaram de 3-5 anos. Este padrão epidemiológico se reflete na atual prevalência ( 85\%), que duplicou após 12 anos de circulação do mencionado agente viral.

Estudos clínico-laboratoriais relativos à infecção intra-uterina associada ao eritrovírus B19 foram realizados por Cubel et al. (1996) e Nascimento et al. (1991) que registraram a ocorrência de hidropisia fetal não imunológica em casos relacionados com morte intra-uterina. Estudo prospectivo conduzido por Freitas et al. (1999) em um grupo de gestantes residentes na área urbana de Belém encontrou uma baixa taxa de incidência (2\%) relativa às infecções maternas associadas ao B19, podendo tal fato estar relacionado ao período interepidêmico da investigação.

Outras investigações associando a infecção do B19 com manifestações clínicas do EI, TAC, anemia crônica em imunodeprimidos, portadores do HIV/AIDS, artropatia aguda e hepatite foram realizadas em diversas cidades brasileiras e compõem parte de um amplo espectro clínico ora relacionado ao B19 (CUBEL et al., 1992, 1996; FREITAS et al., 2002; KODURI et al., 2000; OLIVEIRA et al., 1996; PINHO et al., 2001; SETUBAL et al., 2003).

Funciona como receptor celular para parvovírus B19 o antígeno P do sistema P1 (003) de grupos sangüíneos (BROWN et al., 1993) presente na membrana celular externa de 
células sangüíneas da série vermelha, células miocárdicas e hepáticas fetais, células da placenta e células endoteliais (KERR et al., 1995), mas a replicação celular somente foi observada em precursores eritróides (células BFU-E, CFU-E, pronormoblastos e normoblastos) em divisão na medula óssea, que produz citólise e interrupção da eritropoiese (HOLM et al., 1995). Sobrevém quadro de aplasia eritróide com reticulocitopenia, por cerca de 10 dias, evoluindo subclinicamente em indivíduos normais. Esta reticulocitopenia faz-se acompanhar de leucopenia, linfocitopenia e trombocitopenia (MMWR, 1989). No caso de hospedeiros comprometidos, leva a uma anemia de duração e gravidade variáveis, conforme se enquadre em uma das seguintes duas situações: 1) nos pacientes previamente apresentando produção diminuida ou destruição aumentada de eritrócitos (anemias hemolíticas congênitas, outras afecções com hemólise associada, anemia ferropriva, hemorragias, etc.), a infecção pelo parvovírus B19 produz dramática redução no nível de hemoglobina, com sintomas de anemia grave, condição conhecida como TAC; 2) o outro grupo corresponde a indivíduos imunodeprimidos, incapazes portanto de produzir anticorpos $\operatorname{IgG}$, bloqueadores da infecção, que desenvolvem viremia e anemia persistentes (MMWR, 1989).

O feto, dada a sua condição de relativa imunodeficiência, hemácias de vida média curta e volume hemático rapidamente crescente, de certa forma sintetiza os grupos de risco e se constitui em outra vítima potencial de infecção B19 grave. Lise de precursores eritróides não neutralizada por anticorpos determina quadro de anemia grave e hipóxia de caráter crônico, com insuficiência cardíaca, edema e acúmulo de líquido nas cavidades corporais, com possível morte - hidropsia fetal não imunológica (HOLM et al., 1995). Considerando-se ainda o tropismo do vírus para mioblastos fetais, lesões cardíacas (miocardite) poderiam contribuir para o agravamento das condições hemodinâmicas nesses casos.

Anticorpos da classe IgM aparecem por volta do final da $2^{\mathrm{a}}$ semana de infecção, permanecendo até 3-5 meses. Os da classe IgG, na $3^{\text {a }}$ semana, persistindo literalmente pelo resto da vida (FREITAS et al., 1988) Portanto, hidropsia fetal, TAC e depressão persistente da medula óssea em imunocomprometidos são eventos da fase virêmica da doença, bem como ainda, ao que parece, a recentemente descrita síndrome pápulo-purpúrica em luvas e meias (PPGSS) (HEEGAARD; HORNSLETH, 1995) cujas manifestações clínicas surgem anteriormente à resposta anticorpogênica pelos doentes. EI e artropatia são considerados eventos tardios da infecção, surgindo a partir do $17^{\circ}-18^{\circ}$ dia, já quando o organismo estabeleceu uma resposta imune IgM-IgG definida (ANDERSON, L. J., 1990). DNA e proteinas do capsideo têm sido demonstrados em lesões cutâneas, tanto de EI como de 
PPGSS, nas seguintes estruturas: estrato basal da epiderme, ceratinócitos epidérmicos, células endoteliais dos vasos dérmicos e células epiteliais das glândulas e dutos sudoríparos écrinos. Ainda não foi possível determinar se ocorre replicação produtiva do B19 na pele ou se o DNA e proteinas presentes seriam simples conseqüência de depósito viral (ARACTINGI et al., 1996).

Em suma, as manifestações cutâneas e sistêmicas da infecção pelo parvovírus B19 parecem resultar, como em outras doenças viróticas, de uma série de interações entre o vírus e a resposta imune do hospedeiro. A diversidade de quadros clínicos hoje atribuidos a esse agente tem-se baseado tanto em resultados de provas sorológicas compatíveis com infecção primária como na detecção do ADN viral no soro e nos tecidos através do PCR. Haja vista a elevada sensibilidade deste último método, referida detecção poderia se fazer até 70 dias após o início da infecção, tornando fortuita uma possível relação causal com determinado quadro clínico. Ainda não foi comprovada a ocorrência de embriopatias relacionadas com a virose (FREITAS et al., 1988).

A resolução clínica da infecção aguda do B19 está associada com a emergência de anticorpos $\mathrm{IgG}$, principalmente direcionados às proteínas estruturais VP1 e VP2 do eritrovírus B19 (AZZI et al., 2004; ROSENFELD et al., 1994). Além disso, a infecção pelo B19 induz uma persistente ativação da resposta celular do linfócito T CD8+ (ISA et al., 2005). A presença de anticorpos $\mathrm{IgG}$, juntamente com uma forte resposta de linfócitos $\mathrm{T}$ citotóxicos (CTL), podem desempenhar um papel determinante em indivíduos imunocompetentes submetidos a reinfecção (NIKKARI et al., 1996; ZAKREZWSKA et al., 2001). O eritrovírus B19 tem se mostrado capaz de reinfectar e persistir em pacientes imunocomprometidos (FLUNKER et al., 1998).

\subsubsection{Modelo de transmissão experimental}

Estudos experimentais envolvendo inoculação intranasal do eritrovírus B19 em voluntários produziram manifestações clínicas, hematológicas e imunológicas (ANDERSON, M. J. et al., 1985). No trabalho realizado com voluntários, observou-se que após inoculação intranasal do vírus, o mesmo foi encontrado nas secreções respiratórias e sangue após 1-5 dias de realizada a inoculação. Em alguns voluntários foi registrada uma intensa viremia $\left(\sim 10^{11}\right.$ cópias do genoma por $\mathrm{mL}$ de soro), durante 4-5 dias. A seguir surgiram sintomas inespecíficos como febre, mal estar, mialgias, náuseas e cefaléia. Em alguns voluntários a infecção apresentou-se de forma assintomática. 
Análises hematológicas revelaram a presença de reticulocitopenia, e queda nos níveis de hemoglobina. Concomitantemente foram observadas reduções temporárias nos níveis de plaquetas, leucócitos e neutrófilos, bem como em precursores eritróides da medula óssea, sendo normalizada ao final da fase de viremia nos indivíduos imunocompetentes. Anticorpos IgM surgiram entre 9 a 10 dias depois da inoculação e os da classe IgG após 15 dias (Figura 4). Estes últimos com níveis elevados após o $14^{\circ}$ dia da inoculação. Exantema e artralgia, manifestações clínicas características da infecção pelo B19, apareceram 17 a 18 dias a partir do inicio da infecção. $\mathrm{O}$ aparecimento simultâneo de anticorpos com exantema e artralgia sugere que tais manifestações sejam desencadeadas por imunocomplexos. (COHEN, 1988).

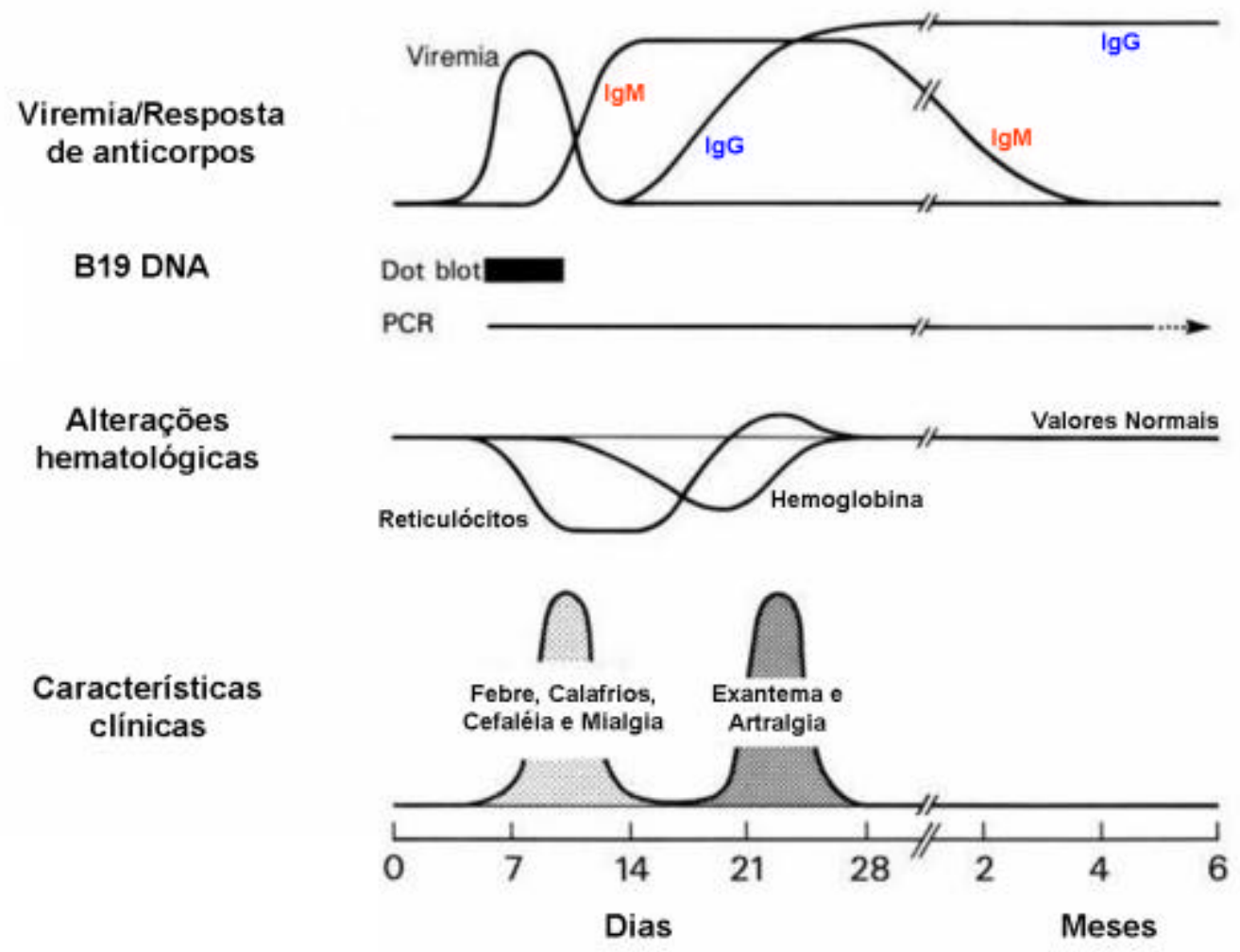

Figura 4- Representação esquemática dos eventos virológicos, hematológicos e clínicos da infecção pelo B19 em voluntários humanos sadios. (Fonte: Heegaard e Brown, 2002)

Estudo recentes mostraram que o parvovirus B19 pode infectar células de primatas não-humanos e consequentemente utilizá-los como modelos experimentais em potencial (GALLINELLA et al., 1995). 


\subsection{Manifestações clínicas}

\subsubsection{Crise aplástica transitória}

A TAC foi a primeira doença associada ao B19, sendo originalmente descrita em pacientes portadores de anemia hemolítica crônica, anemia falciforme, talassemia e esferocitose hereditária (KELLEHER et al., 1983; PATTISON et al., 1981; SERJEANT et al., 1981). Trata-se de aplasia de precursores eritróides na medula óssea, originando um quadro de anemia grave decorrente da infecção pelo B19 (CUBEL et al., 1992; KELLERMAYER et al., 2003; SANT'ANNA et al., 2002; SETUBAL et al., 2000). Nos indivíduos hematologicamente normais, com taxas de hemoglobina que variam de 110-140 g/l e hemácias com tempo de vida em torno de 120 dias; a infecção regride espontaneamente com desaparecimento dos distúrbios hematológicos (PATTISON et al., 1981) após aparecerem os anticorpos específicos.

Nos pacientes portadores de discrasias sanguíneas (anemia hemolítica crônica, talassemia, esferocitose hereditária, anemia falciforme) que apresentam baixas taxas de hemoglobina (70-100 g/l) e hemácias com período de vida curto ( 20 dias), o quadro clínico é grave, caracteriza-se pelo aparecimento de palidez, astenia e letargia, com eminente risco de vida face ao bloqueio medular versus a elevada demanda por hemácias (PATTISON et al., 1981). Nas situações mais graves requer-se o uso de transfusões sanguíneas (ANDERSON, M. J. et al., 1982; SERJEANT et al., 1981), bem como tratamento com imunoglobulina humana via intravenosa (FRICKHOFEN et al., 1990). Tais pacientes são altamente virêmicos e representam um risco elevado de transmissão para outros indivíduos (ANDERSON, M. J. et al., 1982). O eritrovírus B19 está associado a 95\% dos casos relacionados à crise aplástica, com maior ocorrência entre os indivíduos abaixo dos 15 anos de idade (KELLEHER et al., 1983; SMITH et al., 1988; YOUNG et al., 1984).

A infecção pelo B19 pode causar crise aplástica nos indivíduos que estejam com stress da linhagem eritrocitária, desencadeado por hemorragia, deficiência de ferro e após transplante de medula óssea (KOJIMA et al., 1988; NIITSU et al., 1990; WEILAND et al., 1989). 


\subsubsection{Eritema infeccioso}

O Eritema Infeccioso (EI) ou Quinta Doença da Infância foi registrado pela primeira vez na Inglaterra por Anderson M. J. et al. (1984). É uma doença bifásica que apresenta dois períodos distintos: virêmico (febre baixa, mialgia, mal estar geral e cefaléia) e pós-virêmico (erupção cutânea e artralgia); este último ocorre duas semanas após o inicio das manifestações clínicas iniciais. O EI representa uma doença freqüente em crianças (5 a 14 anos), porém pode ocorrer entre adultos (FIGUEIREDO et al., 2005; HOEBE et al., 2002; PEREIRA et al., 2001). Na infância apresenta-se de forma moderada, caracterizando-se por eritema na face (fácies "esbofeteada"), progredindo com exantema máculo-papular eritematoso para o tronco, membros superiores e inferiores. A erupção cutânea típica pode ser pruriginosa ou urticariforme (VUORINEN et al., 2002) e estar acompanhada de febre baixa. Após alguns dias o rash se torna esmaecido, exibe aspecto rendilhado ou circinado, com regressão em até três semanas. A intensidade e a duração do exantema podem variar com a exposição a estímulos não-específicos como estresse, luz solar, variação da temperatura ambiente e na vigência de corticoterapia sistêmica (ANDERSON, L. J. et al., 1987; LINHARES et al., 1991; NAIDES et al., 1999).

\subsubsection{Artropatias}

A artrite associada ao B19 foi descrita pela primeira vez em 1985 (REID et al., 1985; UENO et al., 1993; WHITE et al., 1985). Nas crianças com EI, é usualmente moderada e de curta duração, o acometimento das articulações foi estimado em 10\% (NOCTON et al., 1993; WOOLF et al., 1989; CASSINOTTI et al., 1995), enquanto que ultrapassa $50 \%$ em adultos (LENNEZ et al., 2003; OLIVEIRA \& al., 1999; WHITE et al., 1985). Artralgia e artrite são as manifestações clínicas mais freqüentes da infecção primária do B19 em adultos, afetando $60 \%$ das mulheres e $30 \%$ dos homens. Em contrapartida, a erupção cutânea se mostra menos frequiente nos indivíduos adultos (ANDERSON, M. J. et al., 1985; FREITAS et al., 2002; JOSEPH, 1986; WOOLF et al., 1989). A artralgia é geralmente simétrica, com envolvimento principalmente das articulações das mãos e pés, geralmente dura 1 a 3 semanas, entretanto, pode persistir por meses (FREITAS et al., 2002; WOOLF et al., 1989). O edema e a dor, causando considerável limitação de movimentos, geralmente ocorrem simultaneamente de forma mais pronunciada nas articulações metacárpicas falangianas, $75 \%$, joelhos, $65 \%$, pulsos, $55 \%$, e tornozelos, $40 \%$. Cabe assinalar que não ocorre qualquer erosão articular (WOOLF, 1990). 
A artropatia é presumivelmente mediada pelo sistema imunológico, já que a instalação das manifestações articulares coincide com o aparecimento de anticorpos anti-B19 (WOOLF, 1990). Na ausência de manifestações eruptivas, o quadro clínico pode ser confundido com artrite reumatóide aguda, especialmente porque a infecção pelo B19 pode estar associada com a produção de fatores reumatóides (LUZZI et al., 1985; RAY et al., 2001). O diagnóstico diferencial da infecção pelo B19 deve ser considerado em qualquer paciente que apresente artrite reumatóide juvenil. Em contraste com a artrite reumatóide, a infecção pelo B19 não tem sido relacionada à destruição de articulações em prazo mais longo.

\subsubsection{Infecção fetal}

Infecções fetais frequientes causadas pelos eritrovírus em diversos animais (ovinos, bovinos, caninos) levantaram a suspeita quanto a evidências similares entre os seres humanos. O primeiro relato comprovado registrou a detecção de IgM anti- B19 no sangue de um natimorto e da sua mãe (KNOTT et al., 1984). Numa segunda situação, Brown et al. (1984) detectaram a presença de DNA do eritrovírus em tecido fetal utilizando a técnica da hibridização.

Estudos subseqüentes assinalaram a ocorrência de abortos espontâneos em mulheres gestantes infectadas pelo B19, comprovados pela visualização de partículas virais e detecção do DNA em tecidos do feto no decurso da gestação e morte intrauterina (ANDERSON, L. J. et al., 1990b; CAUL et al., 1988; DOBEC et al., 2007; MORTIMER et al., 1985; NASCIMENTO et al., 1991; YAEGASHI et al., 2000). O feto representa uma síntese dos grupos de risco, haja vista a grande demanda por hemácias e sua relativa imunodeficiência. O mecanismo pelo qual o feto desenvolve a hidropisia fetal é similar ao que ocorre na chamada crise aplástica, em que a infecção viral determina anemia grave, precipitando a falência cardíaca, anasarca e morte (ERGAZ; ORNOY, 2006). Acresça-se que os eritroblastos presentes no fígado do feto, assim como a miocardite podem concorrer para os eventos patogenéticos que se traduzem nas condições clínicas em geral graves (SERVANT et al., 2002).

A maioria dos casos de hidropisia fetal não-imune associada ao B19 ocorre no $2^{\circ}$ trimestre da gestação, 4 a 5 semanas (máximo de 11 semanas) após se instalar a infecção materna (REDDY et al., 2005; CHISAKA et al., 2006). O aborto espontâneo e a morte intrauterina são mais freqüentes no $1^{\circ}$ e $3^{\circ}$ trimestres da gestação, respectivamente (NYMAN et al., 2002); entretanto, a infecção no feto pode ser resolvida espontaneamente, resultando em 
uma criança normal sem complicações posteriores (MOREY et al., 1991; XU et al., 2003). Anemia fetal pode ser corrigida pela ex-sanguíneotransfusão (SCHILD et al., 1999). Registrese que a infecção pelo B19 durante a gravidez é geralmente ignorada, simplesmente porque a maioria das gestantes infectadas é assintomática ou tem manifestações discretas (WONG et al., 2002). O eritema cutâneo e as queixas de artralgia e artrite são os sintomas mais comuns nas gestantes infectadas. A técnica de PCR tem sido sugerida nos testes pré-natais para prevenir infecções intrauterinas pelo B19 (KOCH et al., 1993). Importante ressaltar um caso de transmissão materna relacionada ao genótipo 3 dos eritrovírus humanos (CANDOTTI et al., 2006).

\subsubsection{Outras condições clínicas associadas ao eritrovírus B19}

A púrpura trombocitopênica idiopática acomete crianças e adultos, sendo freqüentemente precedida por uma infecção viral inespecífica (KAPLAN et al., 1992). A infecção pelo B19 pode esultar em trombocitopenia, sendo registrada em pacientes ou voluntários (ANDERSON, M. J. et al., 1985; MURRAY et al., 1994; YOTO et al., 1993). A trombocitopenia associada ao B19 parece ter dois componentes: um do tipo central e outro periférico (KAPLAN et al., 1992). A trombocitopenia de origem central é devida à supressão da eritropoeise na medula óssea e o seu possível efeito citopatoló gico estaria relacionado com a proteina NS1, capaz de inibir colônias de células megacariocíticas (OZAWA et al., 1988; SRIVASTAVA et al., 1990), demonstrando que proteínas virais podem ser tóxicas para populações celulares não-permissivas à replicação do DNA viral. A trombocitopenia destrutiva de origem periférica pode resultar na produção de anticorpos anti-plaquetários mediados imunologicamente, com subseqüente destruição das plaquetas no sistema reticuloendotelial (INOUE et al., 1991).

Casos de neutropenia crônica da infância e pancitopenia transitória foram associados ao eritrovírus B19, sendo verificada a presença de DNA desse agente viral na medula óssea de crianças com tais quadros clínicos (ISA et al., 2006; SCHEURLEN et al., 2001). As doenças neurológicas como encefalopatias (NIGRO et al., 1994; ZERBINI et al., 1992), neuropatias (FADEN et al., 1990), amiotrofia ne urálgica (DENNING et al., 1987) e meningite asséptica (CASSINOTTI et al., 1993; OKUMURA et al., 1993) foram associadas ao B19 em decorrência da detecção de anticorpos e/ou presença do DNA no sangue e líquido céfalo-raquidiano em casos fatais (HEEGAARD et al., 1995) e não fatais (NIGRO et al., 1994). O mecanismo pelo qual o vírus transpõe a barreira hemato-encefálica é ainda 
desconhecido. Casos de miocardite e pericardite foram associados à infecção pelo eritrovírus B19 (CHIA et al., 1996; HEEGAARD et al., 1995).

Achado histológico evidencia o DNA do vírus em núcleos de miócitos fetais, demonstrando o tropismo cardíaco do B19 (BERRY et al., 1992; BOCK et al., 2005). Casos de miocardite e pericardite associados à infecção pelo B19 são intrigantes, mas podem estar relacionados à presença do antígeno $\mathrm{P}$ (receptor celular do B19) em miócitos (O’MALLEY et al., 2003). Hepatites em pacientes com disfunção hepática com ou sem a co-infecção pelos vírus das hepatites B e C têm sido associados à infecção pelo eritrovírus B19 (LEE et al., 2002; ÖZÇAY et al., 2006; PINHO et al., 2001; POOLE et al., 2004; SOKAL et al., 1998; TOAN et al., 2006b). Casos de hepatite fulminante em pacientes que realizaram transplante renal (MARCHAND et al., 1999; WANG et al., 1999) ou administração de imunoglobulina intravenosa (HAYAKAWA et al., 2002) foram registrados, com detecção, nos espécimes sorológicos, de anticorpos IgM e a presença do DNA viral. A doença de Kawasaki (NIGRO et al., 1994), poliarterite nodosa (CORMAN et al., 1992), síndrome papular púrpurica de "luvas e meias" (PASSONI et al., 2001), dermatomiosite (CHEVREL et al., 2000), lúpus eritematoso sistêmico (MAGRO et al., 2000; TAKAHASHI et al., 1998), pneumonia grave (JANNER et al., 1994), glomerulonefrite aguda (DIAZ et al., 2000; NAKAZAWA et al., 2000), fibrose idiopática pulmonar (MAGRO et al., 2003), neuropatia do plexo-braquial, vasculites sistêmica necrotizante (FINKEL et al., 1994) também foram associados à infecção B19. Há necessidade, contudo, de estudos mais abrangentes para confirmar esta presuntiva relação causal. Os processos assintomáticos são estimados em $20 \%$ a $50 \%$ durante as epidemias de EI (HEEGAARD; HORNSLETH, 1995).

\subsubsection{Infecção em pacientes imunodeficientes}

Os pacientes imunocomprometidos são incapazes de produzir anticorpos IgG neutralizantes contra o B19. A infecção persistente desse vírus em precursores eritróides ao nível de medula óssea conduz a um quadro de anemia crônica (CHISAKA et al., 2003). Entre as condições predisponentes incluem-se a infecção pelo vírus HIV/AIDS (NOLAN et al., 2003; SETUBAL et al., 2003), síndrome de Nezelof (KURTZMAN et al., 1987), leucemias linfocítica aguda (KOCH et al., 1990), mielóide crônica e aguda linfoblástica (CORCORAN et al., 2006; FRICKHOFEN et al., 1992), síndrome mielodisplásica (HASLE et al., 1996), linfoma de Burkitt (COUROUCE et al., 1984), transplante de medula óssea (SCHLEUNING et al., 1999) e tratamento do câncer com quimioterápico (GRAEVE et al., 1989). Em certos 
casos, a terapia com imunossupressores deve ser reduzida e administrada a imunoglobulina hiperimune intravenosa (KURTZMAN et al., 1989a, 1989b).

Nesses pacientes imunodeficientes não é possível à formação de imunocomplexos para eliminar o vírus do organismo. Nestes casos, o diagnóstico laboratorial da infecção produzida pelo B19 é essencialmente possível através da detecção do DNA viral (CLEWLEY, 1989; DURIGON et al., 1993).

\subsection{Tratamento}

Medicações sintomáticas são eventualmente necessárias para as manifestações mediadas por imuno-complexos (EI e artropatias). As seguintes medidas são tomadas em situações especiais: 1) os quadros agudos, em regra dramáticos de TAC, exigem pronto diagnóstico e reposição globular adequada, para correção da anemia; 2) pacientes apresentando anemia crônica devem receber imunoglobulina endovenosa. Kurtzman et al. (1989a) a utilizaram na dose de 400mg/kg/dia, em ciclos de 10 dias, até a negativação do PCR no sangue e na medula óssea em paciente portador de aplasia das células vermelhas com dez anos de evolução. Esses autores obtiveram boa resposta reticulocitária e normalização dos níveis de hemoglobina. A dose recomendada pelo fabricante do produto comercializado no Brasil (Sandoglobulina ®, Novartis, São Paulo) para infecções virais, é de 0,4 a $1 \mathrm{~g} / \mathrm{kg} / \mathrm{dia}$, durante um a quatro dias. Ramage et al. (1994) associaram plasmaferese à imunoglobulina e obtiveram resolução da aplasia medular que apresentava mulher de 24 anos submetida a transplante de fígado e imunossupressão medicamentosa; 3) transfusão sangüínea intra- uterina é procedimento considerado de alto risco para casos de hidropisia fetal, haja vista a possibilidade, entre outras, de regressão espontânea do quadro (BOUSQUET et al., 2000; HEEGAARD; HORNSLETH, 1995). O feto hidrópico também se pode beneficiar do tratamento com imunoglobulina específica (HEEGAARD; HORNSLETH, 1995).

Futuras vacinas com vírus vivo modificado, inativado ou mesmo uma vacina recombinante serão utilizadas rotireiramente para conferir proteção contra a parvovirose humana (FARR; TATTERSALL, 2004; WALTERS et al., 2004).

\subsection{Diagnóstico laboratorial}

O diagnóstico da infecção produzida pelo eritrovírus B19 depende basicamente da fase aguda (virêmica) ou convalescente (pós-virêmica) em que o espécime clínico é colhido. 
No período virêmico o diagnóstico pode ser estabelecido pela identificação direta do vírus, presença dos antígenos virais ou do DNA viral. No período pós-virêmico o diagnóstico pode ser realizado pela detecção de anticorpos específicos das classes IgM e IgG produzidos pelo organismo do paciente infectado.

\subsubsection{Diagnóstico direto}

A replicação in vitro do B19 ocorre em sistemas de culturas primárias de medula óssea humana (OZAWA et al., 1986), fígado fetal (BROWN et al., 1991), células do cordão umbilical (SRIVASTAVA et al., 1992), bem como do sangue periférico (SERKE et al., 1991). Entretanto, esses sistemas primários não são adequados para culturas de longo prazo, além do freqüente registro de contaminação. Atualmente, outras linhagens celulares nãoconvencionais originárias de leucemia megacarioblásticas, MB-02 (MUNSHI et al., 1993) e UT-7/Epo (SHIMOMURA et al., 1992), bem como duas linhagens de leucemia eritróide humana JK-1 (TAKAHASHI et al., 1993) e KU812Ep6 (MIYAGAWA et al., 1999) foram consideradas adequadas à propagação do B19. Observações posteriores mostraram que tais sistemas celulares são pouco eficientes devido à produção de baixos títulos virais, além do alto custo desses métodos (KURTZMAN et al., 1988).

$\mathrm{Na}$ fase de viremia, partículas virais podem ser visualizadas diretamente no soro usando a microscopia eletrônica e/ou imunomicroscopia eletrônica (CAUL et al., 1988; CHRYSTIE et al., 1990; PILAVDZIC et al., 1994). Antígenos virais podem ser detectados em amostras de soro pelos métodos de radioimunoensaio (ANDERSON, M. J. et al., 1982) ou ensaio imunoenzimático (ANDERSON, L. J. et al., 1986; CUBEL et al., 1996). A utilização de sondas moleculares possibilitou a detecção direta do B19 em células sanguíneas e tecidos infectados (CLEWLEY et al., 1985). Na atualidade, o emprego de sondas com marcadores específicos conferiu maior sensibilidade à técnica de hibridização (ZERBINI et al., 2000, 2001).

A introdução dos métodos de amplificação do genoma viral fez com que a técnica da reação em cadeia da polimerase (PCR) se tornasse o método diagnóstico mais sensível para detecção do B19 em espécimes clínicos (CLEWLEY et al., 1989; DURIGON et al., 1993; ERDMAN et al., 1991). O emprego do nested-PCR, uma amplificação adicional contendo primers internos específicos que reconhecem seqüências nucleotídicas do produto previamente, amplificado conferiram maior sensibilidade ao método de PCR (CASSINOTTI et al., 1993; DURIGON et al., 1993; HEMAUER et al., 1996; ZERBINI et al., 1999). A 
padronização das técnicas imunoenzimáticas utilizando sondas não radioativas, o método da imuno-quimioluminescência para detecção do produto amplificado, tornou a reação da PCR ainda mais sensível e específica para o diagnóstico laboratorial da infecção pelo B19 (BOGGINO et al., 2000; DURIGON et al., 1994; ERDMAN et al., 1994; GRUBER et al., 2001; VIEIRA et al., 2001).

\subsubsection{Diagnóstico indireto}

$\mathrm{Na}$ fase de convalescença (pós-virêmica), o paciente imunocompetente desenvolve anticorpos específicos das classes $\operatorname{IgM}$ e IgG contra o eritrovírus B19, que podem ser detectados e quantificados pelos métodos de radioimunoensaio (ANDERSON, M. J. et al., 1982; COHEN et al., 1997), imunoenzimáticos e imunofluorescência (ANDERSON, L. J. et al., 1986; DOYLE et al., 2000; KERR et al., 1996; NASCIMENTO et al., 1998).

$\mathrm{Na}$ atualidade existem disponíveis no mercado kits para detecção de anticorpos IgM e IgG pelos métodos imunoenzimático e de imunofluorescência. Tais kits utilizam como antígeno proteínas estruturais (VP1 e VP2) do B19, expressas em células de insetos com baculovírus (KAJIGAYA et al., 1989). Es tudo realizado por Cohen et al. (1995) revelou a existência de diferentes sensibilidades e especificidades entre os kits usados para detecção de anticorpos específicos da classe $\operatorname{IgM}$, principalmente quando os mesmos são submetidos a painéis de soros provenientes de indivíduos com diferentes manifestações clínicas. Para ampliar a sensibilidade e especificidade foi sugerida a utilização de anticorpos monoclonais (BROWN et al., 1989; COHEN et al., 1983; FRIDEL et al., 1991; MORINET et al., 1991).

Estudos desenvolvidos por Cubel et al. (1994), usando antígenos capsulares recombinantes do B19 sem a presença de inibidores do soro humano, demonstraram que a reação de hemadsorção com hemácias de símios (Cinomolgus spp) pode ser uma alternativa à técnica imunoenzimática para captura de anticorpos específicos do mencionado agente viral. 


\section{CASUÍSTICA E MÉTODOS}

Neste estudo foram selecionados 487 espécimes biológicos (soro e plasma) procedentes da coleção de amostras clínicas da Seção de Virologia do Instituto Evandro Chagas (IEC), órgão da Secretaria de Vigilância em Saúde, Ministério da Saúde. O objetivo precípuo desse banco é possibilitar os estudos retrospectivos sobre agentes virais emergentes e re-emergentes responsáveis por problemas relacionados à saúde pública na Amazônia e no Brasil. O banco de amostras clínicas da Seção de Virologia recebe diariamente espécimes procedentes da área urbana de Belém e municípios do Estado do Pará, bem como de outros locais da Amazônia como Amazonas, Roraima e Amapá, enviados pelos órgãos das Secretarias Estaduais de Saúde, Laboratórios Centrais (LACENs), visando ao esclarecimento diagnóstico das doenças virais e particularmente aquelas relacionadas a quadros exantemáticos. As amostras foram selecionadas de pacientes apresentando sintomas e sinais sugestivos de infecção pelo eritrovírus B19, entre as quais as doenças exantemáticas [grupo I, $(n=207)]$, desordens hematológicas [grupo II, $(n=188)$ ], artropatias agudas [grupo III, $(n=67)$ ] e outras condições clínicas relacionadas ao eritrovírus B19 como encefalites, miocardiopatias, hepatites e lupus eritematoso sistêmico [grupo IV, $(\mathrm{n}=25)$ ]. O período de 10 anos (janeiro de 1995 a dezembro de 2005) corresponde a dois ciclos de maior e menor atividade viral do B19, considerando seu perfil epidemiológico na área urbana de Belém.

\subsection{Pacientes e espécimes biológicos}

O estudo foi realizado com amostras clínicas colhidas na Seção de Virologia do IEC, no período de janeiro de 1995 a dezembro de 2005. Foram selecionadas amostras de 487 pacientes de ambos os sexos e idades entre 1 mês e 80 anos (mediana, $18 \pm 11$ anos), com sintomas e sinais sugestivos de infecção pelo eritrovírus B19. As amostras de soro e plasma foram obtidas por punção venosa, via antecubital, com sistema de coleta a vácuo utilizando tubo com e sem anticoagulante, no qual o espécime foi separado após centrifugação a $2.000 \mathrm{~g}$ por 5 minutos a $4{ }^{\circ} \mathrm{C}$. Após a separação do soro e plasma, as amostras foram armazenadas em alíquotas, utilizando-se microtubos devidamente identificados. Os espécimes foram mantidos a temperatura de $-20{ }^{\circ} \mathrm{C}$ até a data de seu processamento. 


\subsection{Teste imunoenzimático para a detecção de anticorpos IgM anti- eritrovírus B19 em soro e plasma humano}

Aplica-se à detecção de anticorpos IgM para o eritrovírus B19 em casos de EI, artropatia aguda, TAC em portadores de desordens hematológicas e manifestações clínicas relacionadas à infecção pelo B19 durante a gestação (hidropisia fetal e aborto espontâneo). Os testes foram realizados de acordo com as especificações indicadas pelo fabricante (Biotrin ${ }^{\mathrm{TM}}$ Internacional, Dublin, Irlanda), sendo sua sensibilidade e especificidade de 100\%. Comparado ao radioimunoensaio que é considerado teste padrão-ouro.

\subsubsection{Componentes do kit}

- Microplacas - contendo 12 tiras reunindo 8 cavidades sensibilizadas com imunoglobulinas de coelho anti-IgM humanas;

- Controle IgM positivo - representado por 1 frasco com $2 \mathrm{~mL}$;

- Controle IgM negativo - consistindo de 2 frascos com $2 \mathrm{~mL}$;

- Conjugado enzimático concentrado (estreptavidina-peroxidase-HRP /timerosal), - 1 frasco com 1,4 mL;

- Diluente do conjugado enzimático - 1 frasco com 14 mL;

- Diluente da amostra (pronto para uso) - tampão PBS - 1 frasco com $110 \mathrm{~mL}$;

- Tampão de lavagem concentrado (25 x) - 1 frasco com 45 mL;

- VP2 biotinilado concentrado (10x) - 1 frasco com 1, $4 \mathrm{~mL}$;

- Diluente da VP2 - 1 frasco com $14 \mathrm{~mL}$;

- Substrato (tetrametilbenzidina- TMB) - 1 frasco com $11 \mathrm{~mL}$;

- Solução de bloqueio (ácido sulfúrico) - $\mathrm{H}_{2} \mathrm{SO}_{4}$ 0,5 mol/L - 1frasco com 11 $\mathrm{mL}$.

\subsubsection{Equipamentos utilizados}

Lavadora automática (ELP-40, Bio-Tek, Instruments, Vermont, USA); leitor de microplaca (Multiskan Ex. Labsystems) com filtro de $450 \mathrm{~nm}$; cabine de fluxo laminar tipo II; agitador de tubos (vórtex); geladeira e freezer a $-20{ }^{\circ} \mathrm{C}$. 


\subsubsection{Preparação das amostras}

Amostra de sangue foi colhida de maneira asséptica em tubo seco. Depois da coagulação do sangue o soro foi decantado e conservado à temperatura de $-20{ }^{\circ} \mathrm{C}$. Um mínimo de $100 \mu \mathrm{L}$ de soro foi necessário para realização do teste. A seguir foi distribuído em cada tubo $1 \mathrm{~mL}$ do diluente da amostra. Utilizando-se ponteiras descartáveis foram distribuídos $10 \mu \mathrm{L}$ de cada amostra nos tubos correspondentes, sobrevindo a homogeneização (Vórtex).

\subsubsection{Preparação dos reagentes}

- Solução de lavagem (solução salina concentrada (25x) com Tris, Tween 20 $(0,25 \%)$ e tiomersal $(0,01 \%)$ : para cada tira de 8 cavidades foram acrescentado 3,5 mL do tampão de lavagem concentrado para $84 \mathrm{~mL}$ de água Milli-Q;

- VP2 biotinilada: para cada tira de 8 cavidades foi acrescentado $100 \mu \mathrm{L}$ de VP2 biotinilado concentrado e $900 \mu \mathrm{L}$ de diluente para VP2;

- Conjugado enzimático: para cada tira de 8 cavidades foi acrescentado $100 \mu \mathrm{L}$ de conjugado enzimático concentrado e $900 \mu \mathrm{L}$ de diluente para conjugado.

\subsubsection{Procedimento do teste}

Todos os reativos foram colocados a temperatura ambiente antes do uso (20-25 $\left.{ }^{\circ} \mathrm{C}\right)$. Colocaram-se tiras no apoio, sendo posteriormente cobertas com um adesivo ou tampa plástica; a seguir preparoutse o tampão de lavagem e o de diluição (ver seção 4.2.4). Posteriormente foram diluidos os soros dos pacientes (ver seção 4.2.3) e distribuidos $100 \mu \mathrm{L}$ dos controles negativo e positivo e soros pré-diluidos nas cavidades, que foram cobertas com um adesivo ou tampa plástica e deixadas para incubar à temperatura ambiente por 60 minutos. Cada cavidade foi lavada 4 vezes com o tampão de lavagem (250-300 $\mu \mathrm{L}$ por orificio). A seguir realizou-se o procedimento de inversão da placa, seguido de batidas sobre papel absorvente. Após preparação da VP2 biotinilada (ver seção 4.2.4) foram acrescentados a cada cavidade $100 \mu \mathrm{L}$ do VP2 pré-diluido com posterior cobertura da cavidade com um adesivo ou tampa plástica e incubação à temperatura ambiente por 30 minutos. Seguiu-se lavagem 4 vezes com o tampão apropriado (250-300 $\mu \mathrm{L}$ por orificio) com inversão da placa seguida de batidas sobre papel absorvente. O conjugado enzimático diluido (ver seção 4.2.4) foi acrescentado a cada cavidade, no volume de $100 \mu \mathrm{L}$, cobrindo-se então as cavidades com um 
adesivo ou tampa plástica e incubação à temperatura ambiente por 30 minutos; cada cavidade foi a seguir lavada 4 vezes com o tampão de lavagem (250-300 $\mu \mathrm{L}$ por orificio), repetindo-se o procedimento de inversão da placa seguido de batidas sobre papel absorvente. Acrescentaram-se a cada cavidade $100 \mu \mathrm{L}$ do substrato, seguindo-se incubação à temperatura ambiente por 10 minutos; sem lavar acrescentaram-se imediatamente a cada cavidade $100 \mu \mathrm{L}$ da solução de bloqueio (ácido sulfúrico que foi adicionado a solução na mesma sequência da adição do substrato). A leitura da densidade óptica (D.O) de cada cavidade foi realizada em um espectrofotômetro (Multiskan Ex. Labsystems), utilizando-se comprimento de onda de $450 \mathrm{~nm}, 15$ minutos após a colocação da solução de bloqueio.

\subsubsection{Cálculo do cut-off}

Este valor é calculado multiplicando-se a média das D.O do controle positivo (C.P) por uma constante específica de cada lote (LSC- Lot Specific Constant) inscrita na face interna da tampa da caixa:

$$
\mathrm{COV}(\text { cut }- \text { off value })=\mathrm{CP} \times \mathrm{LSC}
$$

\subsubsection{Interpretação dos resultados}

Os resultados foram determinados por comparação da D.O. da amostra com um valor limite calculado (cut-off); 1) positivo: amostra cuja média da duplicata apresenta uma D.O. superior ou igual ao cut-off x 1,1;2) negativo: amostra cuja média da duplicata apresenta uma D.O inferior ou igual ao cut-off x 0,$9 ; 3)$ duvidoso: amostra cuja média da duplicata apresenta uma D.O compreendida entre (cut-off x 1,1) e (cut-off x 0,9). Toda amostra com resultado duvidoso foi retestada com uma nova diluição do soro. Na presença de novo resultado duvidoso foi realizado um novo teste com uma outra amostra colhida uma semana mais tarde.

\subsection{Teste imunoenzimático para a detecção de anticorpos IgG anti- eritrovírus B19 em soro e plasma humano}

Aplica-se à detecção de anticorpos IgG do eritrovírus B19 em casos EI, artropatia aguda, TAC, em portadores de desordens hematológicas, em manifestações clínicas relacionadas à infecção do B19 durante a gestação (hidropisia fetal e aborto espontâneo). Os testes foram realizados de acordo com as especificações recomendadas pelo fabricante (Biotrin ${ }^{\mathrm{TM}}$ Internacional, Dublin, Irlanda) sendo sua sensibilidade e especificidade de $100 \%$. 


\subsubsection{Componentes do Kit}

- Microplacas - 12 tiras com 8 cavidades sensibilizadas com proteína recombinante VP2;

- Controle IgG positivo - 1frasco com $2 \mathrm{~mL}$;

- Controle IgG negativo - 1 frascos com $2 \mathrm{~mL}$;

- Conjugado enzimático - anticorpos (de coelho) anti-IgG humana marcados com peroxidase - 1 frasco com $13 \mathrm{~mL}$;

- Diluente de amostra (pronto para uso) - 1 frasco com $110 \mathrm{~mL}$;

- Tampão de lavagem concentrado (25 x);

- Substrato (tetrametilbenzidina -TMB) - 1 frasco com $11 \mathrm{~mL}$;

- Solução de bloqueio (ácido sulfúrico) - $\mathrm{H}_{2} \mathrm{SO}_{4}$ 0, 5 mol/L - 1frasco com 11 $\mathrm{mL}$.

\subsubsection{Equipamentos}

Lavadora automática (ELP-40, Bio-Tek Instruments, Vermont, USA); leitor de microplaca (Multiskan Ex. Labsystems) com filtro de $450 \mathrm{~nm}$; cabine de fluxo laminar tipo II; agitador de tubos (vórtex); geladeira; freezer a $-20{ }^{\circ} \mathrm{C}$; agitador de microplaca.

\subsubsection{Preparação das amostras}

Foi colhida uma amostra de sangue, de maneiro asséptica, em tubo seco. Depois da coagulação do sangue o soro foi decantado e conservado à temperatura de $-20{ }^{\circ} \mathrm{C}$. Um mínimo de $100 \mu \mathrm{L}$ de soro são necessários para a realização do teste. A seguir foi distribuído em cada tubo, $1 \mathrm{~mL}$ do diluente da amostra. Utilizando-se ponteiras descartáveis foram distribuídos $10 \mu \mathrm{L}$ de cada amostra nos tubos correspondentes, com subseqüente homogeneização.

\subsubsection{Preparação dos reagentes}

Tampão de lavagem (solução salina concentrada (25x) com Tris, Tween 20 $(0,25 \%)$ e tiomersal $(0,01 \%)$ : para cada tira de 8 cavidades 6 ram acrescentados $4 \mathrm{~mL}$ de 
tampão de lavagem concentrado para $76 \mathrm{~mL}$ de água Milli-Q; todos os reagentes restantes se encontravam prontos para uso.

\subsubsection{Procedimento do teste}

Todos os reativos foram colocados à temperatura ambiente antes do uso (20-25 $\left.{ }^{\circ} \mathrm{C}\right)$. Colocaram-se tiras no apoio sendo posteriormente cobertas com um adesivo ou tampa plástica; a seguir preparou-se o tampão de lavagem (ver seção 4.3.4) sendo que o restante dos reagentes já estavam prontos para uso; os soros dos pacientes foram pré-diluidos (ver seção 4.3.3) e distribuidos $100 \mu \mathrm{L}$ do controle negativo, positivo e soros pré-diluidos nas cavidades; com posterior cobertura com um adesivo ou tampa plástica. Incubou-se à temperatura ambiente por 60 minutos. Cada cavidade foi lavada 4 vezes com o tampão de lavagem (250$300 \mu \mathrm{L}$ por orificio)com posterior inversão da placa, seguido de batidas sobre papel absorvente. Acrescentou-se a cada cavidade $100 \mu \mathrm{L}$ do conjugado, sendo a seguir cobertas as cavidades com um adesivo ou tampa plástica, com subsequente incubação à temperatura ambiente por 30 minutos. Cada cavidade foi lavada 4 vezes com o tampão de lavagem (250$300 \mu \mathrm{L}$ por orifício); sendo realizado procedimento de inversão da placa, seguido de batidas sobre papel absorvente. Acrescentou-se a cada cavidade $100 \mu \mathrm{L}$ do substrato com posterior incubação à temperatura ambiente por 10 minutos; sem lavar, acrescentou-se imediatamente a cada cavidade $100 \mu \mathrm{L}$ da solução de bloqueio (ácido súlfurico que foi adicionado a solução na mesma sequência da adição do substrato). A leitura da D.O de cada cavidade foi realizada em um espectrofotômetro (Multiskan Ex. Labsystems) utilizando comprimento de onda de 450nm, 15 minutos após a colocação da solução de bloqueio.

\subsubsection{Cálculo do cut-off}

Este valor foi calculado multiplicando-se a média das D.O do controle positivo (CP) por uma constante específica de cada lote (LSC-Lot Specific Constant) inscrita na face interna da tampa da caixa:

\section{$\operatorname{COV}($ Cut-off value $)=\mathrm{CP} \times \mathrm{LSC}$}

\subsubsection{Interpretação dos resultados}

Os resultados foram determinados por comparação da D.O da amostra com um valor limite calculado (cut-off); 1) positivo: amostra cuja média da duplicata apresenta uma D.O superior ou igual ao cut-off $\mathrm{x} 1,1$; 2) negativo: amostra cuja média da duplicata apresenta 
uma D.O inferior ou igual ao cut-off x 0,$9 ; 3$ ) duvidoso: amostra cuja média da duplicata apresenta uma D.O compreendida entre (cut-off x 1,1) e (cut-off x 0,9). Toda amostra com resultado duvidoso foi retestada com uma nova diluição fresca do soro. Na presença de novo resultado duvidoso foi realizado um novo teste com uma outra amostra colhida uma semana mais tarde.

\subsection{Extração de DNA utilizando a técnica de fenol-clorofórmio}

A extração de DNA viral utiliza a técnica de fenol - clorofórmio a partir dos espécimes clínicos obtidos de pacientes com sintomas e sinais sugestivos de infecção recente/ativa pelo eritrovírus B19.

\subsubsection{Digestão das amostras de soro e plasma}

Após o descongelamento das amostras, $20 \mu \mathrm{L}$ de cada soro ou plasma fram incubados a $56{ }^{\circ} \mathrm{C}$ por 30 minutos em $150 \mu \mathrm{L}$ de uma solução composta por $10 \mathrm{mM}$ de Tris$\mathrm{HCl}(\mathrm{pH}$ 8,0), $10 \mathrm{mM} \mathrm{NaCl}, 1 \mathrm{mM}$ EDTA (TNE), dodecil sulfato de sódio (SDS) a 10\% e 500 $\mu \mathrm{g}$ de proteinase $\mathrm{K}(\mathrm{PK})$.

\subsubsection{Extração do DNA das amostras de soro e plasma}

Para cada amostra utilizamos 3 microtubos de $1,5 \mathrm{~mL}$ e 1 de $0,5 \mathrm{~mL}$. Foi preparada uma mistura contendo, para cada amostra: $150 \mu \mathrm{l}$ de TNE, $20 \mu \mathrm{L}$ de SDS (10\%), 10 $\mu 1 \mathrm{PK}(10 \mathrm{mg} / \mathrm{mL})$; distribuiram-se $180 \mu \mathrm{L}$ da citada mistura em cada tubo e adicionaram-se $20 \mu \mathrm{L}$ de soro. A seguir foi realizada incubação em banho-maria a $56{ }^{\circ} \mathrm{C}$ por 30 minutos; posteriormente se adicionaram $200 \mu \mathrm{L}$ de fenol saturado; com subseqüente agitação (vórtex) por 1 minuto e centrifugação por 3 minutos (12.000g x). A seguir foram transferidos $150 \mu \mathrm{L}$ do sobrenadante para um microtubo contendo $150 \mu \mathrm{L}$ de fenol/clorofórmio/álcool isoamilico. Ocorreu então agitação (vórtex) por 1 minuto e centrifugação por 3 minutos $(12.000 \mathrm{~g}$ x); a seguir foram transferidos $100 \mu \mathrm{L}$ do sobrenadante para um microtubo contendo $100 \mu \mathrm{L}$ de clorofórmio. Nova agitação (vórtex) ocorreu por 1 minuto, centrifugação por 3 minutos $(12.000 \mathrm{~g}$ x) e, ao final, foram retirados $40 \mu \mathrm{L}$ do sobrenadante tomando cuidado para não aspirar clorofórmio, passando esta quantidade para um microtubo de $500 \mu \mathrm{L}$, sendo posteriormente armazenado à temperatura $-20^{\circ} \mathrm{C}$. 


\subsection{Detecção de DNA do eritrovírus B19 pela técnica da reação em cadeia da polimerase (PCR)}

A detecção do ácido nucléico viral pela técnica da reação em cadeia da polimerase (PCR) em soro e plasma humanos foi realizada segundo DURIGON et al., 1993, para diagnóstico de infecção recente/ativa pelo parvo vírus B19 a partir de espécimes biológicos humanos após extração do DNA viral.

\subsubsection{Descrição dos oligonucleotídeos (primers)}

Foram empregados primers P12 e P16 (externos) que amplificam, no genoma do parvovírus B19, a região estrutural (VP1/VP2), produzindo um fragmento com 563 pares de base (pb). Logo após procedeu-se a uma segunda amplificação (semi-nested PCR), utilizando primers (P13 e P16) que amplificam um fragmento interno ao já amplificado, com 476 pb (Figura 5).

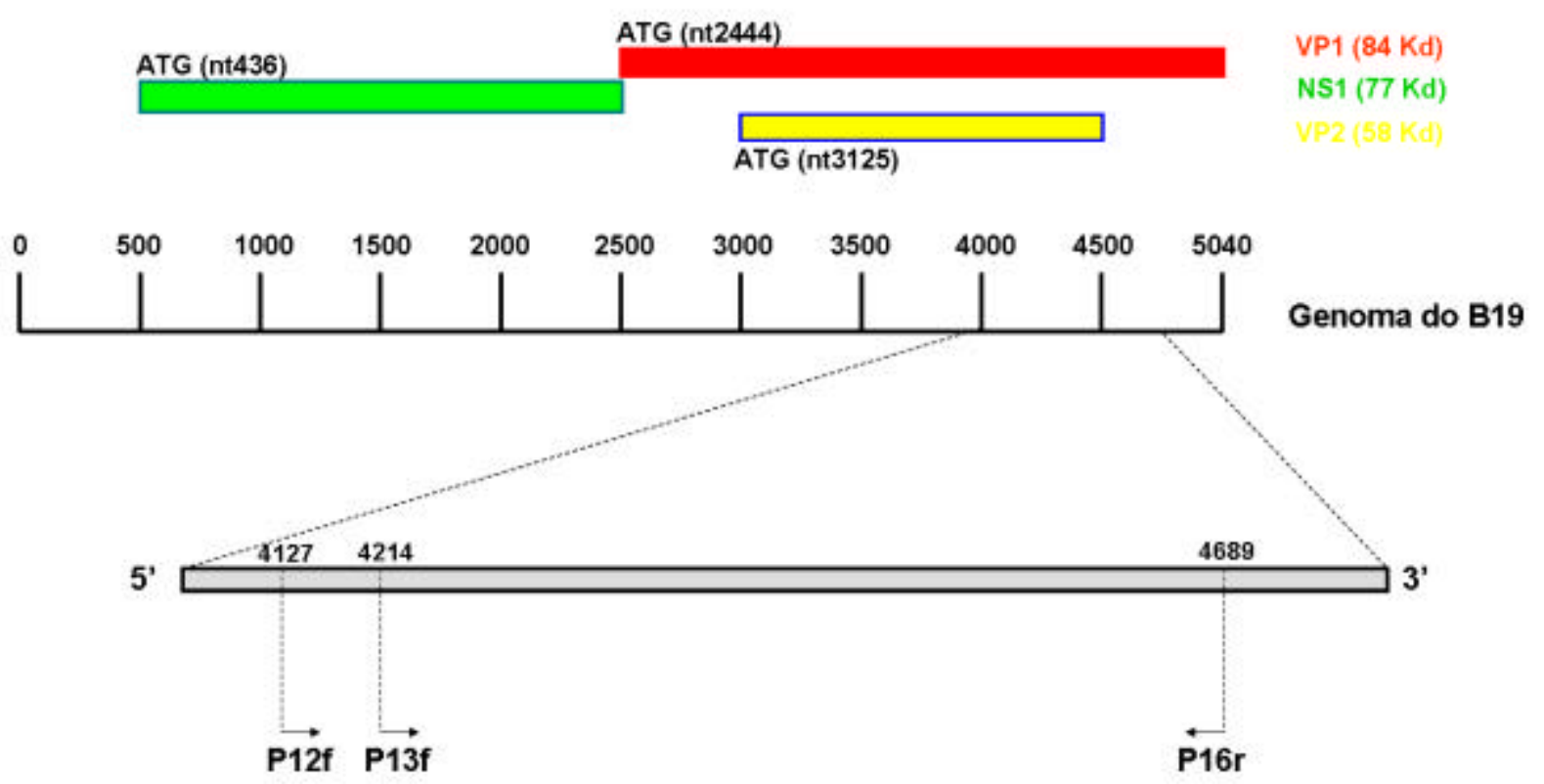

Figura 5 - Esquema do genoma viral, emparelhamento dos primers. Os genes estão identificados de acordo com a proteína que codificam e estão listados logo abaixo do esquema do genoma viral. (Reproduzido a partir da fonte: Astell et al., 1997).

Os primers (Tabela 1) foram preparados pelo método beta-cianoetil fosforamidite (SINHA et al., 1984). 
Tabela 1 - Descrição dos primers utilizados para as reações de PCR e Nested-PCR, locação de cada um na sequência de DNA, região e tamanho do produto amplificado (Erdman et al, 1996).

\begin{tabular}{|c|c|c|c|c|c|}
\hline & PRIMER & $\begin{array}{c}\text { LOCALIZAÇÅO } \\
\text { (DNA) }\end{array}$ & REGIÄO & SEQUENNCIA (5' - 3') & $\begin{array}{c}\text { PRODUTO } \\
\text { AMPLIFICADO }\end{array}$ \\
\hline $\begin{array}{l}P \\
C \\
R\end{array}$ & $\begin{array}{l}\text { P12f } \\
\text { P16r }\end{array}$ & $\begin{array}{l}4127-4148 \\
4689-4665\end{array}$ & $\mathrm{VP} 1 / \mathrm{VP} 2$ & $\begin{array}{l}\text { CAGCCATACCACCACTGGGACA } \\
\text { AGTACATATGGTAAATGACCTGCTG }\end{array}$ & $563 \mathrm{pb}$ \\
\hline $\begin{array}{ll}\mathrm{S} & \mathrm{N} \\
\mathrm{E} & \mathrm{E} \\
\mathrm{M} & \mathrm{S} \\
\mathrm{I} & \mathrm{T} \\
& \mathrm{E} \\
& \mathrm{D}\end{array}$ & $\begin{array}{l}\text { P13f } \\
\text { P16r }\end{array}$ & $\begin{array}{l}4214-4237 \\
4689-4665\end{array}$ & $\mathrm{VP} 1 / \mathrm{VP} 2$ & $\begin{array}{l}\text { GACAAAGAGTATCAGCAAGGAGTG } \\
\text { AGTACATATGGTAAATGACCTGCTG }\end{array}$ & $476 \mathrm{pb}$ \\
\hline
\end{tabular}

\subsubsection{Reação de PCR e semi-nested PCR}

A mistura, tanto para PCR quanto para semi-nested PCR consistiu para reação com volume final de $50 \mu \mathrm{L}$, assim composta:

- 25,25 $\mu \mathrm{L}$ de $\mathrm{H}_{2} \mathrm{O}$ DNAse e RNAse livre;

- $1,5 \mu \mathrm{L}$ de $\mathrm{MgCh}_{2}(50 \mathrm{mM})$;

- $8 \mu \mathrm{L}$ de dNTPs $(1,25 \mathrm{mM})$;

- $5 \mu \mathrm{L}$ de tampão (10 x) (Biotools®, São Paulo, Brasil);

- $2,5 \mu \mathrm{L}$ de primer foward (10 pmol);

- $2,5 \mu \mathrm{L}$ de primer reverse (10 pmol);

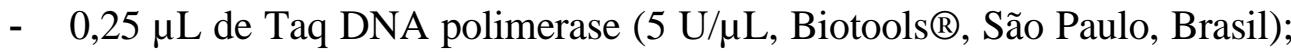

- $5 \mu \mathrm{L}$ do DNA extraído/amplificado.

As amostras foram submetidas ao termociclador (Eppendorf, modelo mastercycler® ep), aplicando o seguinte programa de amplificação: $94{ }^{\circ} \mathrm{C}$ por 5 minutos $(1$ ciclo), seguido de 40 ciclos: $94{ }^{\circ} \mathrm{C}$ por 45 segundos (desnaturação), $72{ }^{\circ} \mathrm{C}$ por 1 minuto e 30 segundos (extensão), $55{ }^{\circ} \mathrm{C}$ por 45 segundos (pareamento) e posteriormente de $72{ }^{\circ} \mathrm{C}$ por 10 minutos (1 ciclo).

\subsubsection{Detecção do produto amplificado por eletroforese}

Os produtos de PCR foram submetidos a uma corrida eletroforética em gel de agarose a $1,5 \%$, com Tris-Borato $(0,045 \mathrm{M})$, EDTA $(1 \mathrm{mM})(\mathrm{TBE} 1 \mathrm{x})$ sob uma voltagem de 100 volts por 30 minutos. A visualização e documentação do produto amplificado em gel de agarose foi feita pela coloração em brometo de etídio $(0,5 \mu \mathrm{g} / \mathrm{mL})$, utilizando um aparelho de 
foto documentação (Vilber Lourmat®, France) com luz ultravioleta (UV). Previamente descrita por SAMBROOK et al., 1989.

\subsection{Purificação do fragmento amplificado}

Completourse o volume de $40 \mu \mathrm{L}$ da solução contendo o fragmento do DNA-alvo para $50 \mu \mathrm{L}$ com $\mathrm{H}_{2} \mathrm{O}$ DNAse e RNAse livre; a seguir foram acrescentados $5 \mu \mathrm{L}(10 \%)$ de acetato de sódio (3M), pH- 5,2; adicionou-se aos $55 \mu \mathrm{L}$ da solução anterior, $110 \mu \mathrm{L}$ de etanol a 100\%; com posterior agitação (vórtex) por 15 segundos, deixando-se à temperatura de -20 ${ }^{\circ} \mathrm{C}$ overnight, centrifugação (Eppendorf®, modelo 5804-R)(19.000g x) por 30 minutos à temperatura de $4{ }^{\circ} \mathrm{C}$; subsequentemente descartou-se o sobrenadante, sendo esgotado o restante do líquido por inversão do microtubo em papel de filtro. Seguiu-se lavagem do sedimento com $150 \mu \mathrm{L}$ de etanol a $70 \%$ e centrifugação $(19.000 \mathrm{~g}$ x) por 10 minutos à temperatura de $4{ }^{\circ} \mathrm{C}$; a seguir foi novamente descartado o sobrenadante, sendo esgotado o restante do líquido por inversão do microtubo em papel de filtro. O microtubo (sedimento) foi seco em centrífuga tipo speed vacuum (Eppendorf®, Alemanha) por 20 minutos à temperatura de $60{ }^{\circ} \mathrm{C}$. O sedimento foi ressuspenso em $\mathrm{H}_{2} \mathrm{O}$ DNAse e RNAse livre e estocado à temperatura de $-20{ }^{\circ} \mathrm{C}$ até sua quantificação em gel de agarose a $1,5 \%$, usando padrão de massa (low mass ladder, invitrogen ${ }^{\circledR}$, USA). Previamente descrita no manual écnico de laboratório publicado por Sambrook et al. (1989).

\subsection{Reação de seqüenciamento}

Para a reação de sequenciamento automático foi utilizado o Kit comercial ABI PRISM BigDye TM Terminator Cycle Sequencing v 3.1 Ready Reaction (Applied Biosystems ${ }^{\circledR}$ ). O DNA obtido após reação de semi-nested PCR (seção 4.5.2), seguido da purificação (seção 4.6), foi utilizado para reação de seqüenciamento com um volume final de $10 \mu \mathrm{L}$, como segue:

- $2 \mu \mathrm{L}$ de BigDye Terminator cycle sequencing reaction (Applied Biosystems $\left.{ }^{\circledR}\right)$;

- $1 \mu \mathrm{L}$ de Tampão (5x) (Applied Biosystems $\left.{ }^{\circledR}\right)$;

- $2 \mu \mathrm{L}$ de Primer forward ou Primer reverse* (2,5 pmol);

- $5 \mu \mathrm{L}$ de DNA alvo.

\footnotetext{
* Para cada reação de sequenciamento foi utilizado um só primer conforme o sentido do sequenciamento.
} 
Após homogeneização a mistura foi levada ao termociclador (Eppendorf, modelo mastercycler ${ }^{\circledR}$ ep, Alemanha), onde foi aplicado o seguinte programa de amplificação: $96{ }^{\circ} \mathrm{C}$ por 2 minutos ( 1 ciclo), seguido de 35 ciclos: $96{ }^{\circ} \mathrm{C}$ por 20 segundos (desnaturação), $50{ }^{\circ} \mathrm{C}$ por 15 segundos (pareamento), $60{ }^{\circ} \mathrm{C}$ por 4 minutos extensão da nova fita de DNA.

\subsection{Precipitação do produto amplificado e seqüienciamento}

Os "terminadores" (prime dime) não incorporados foram removidos através de precipitação diferencial com isopropanol. Para cada $10 \mu \mathrm{L}$ do produto amplificado a partir da reação de seqüenciamento adicionaram-se $30 \mu \mathrm{L}$ de $\mathrm{H}_{2} \mathrm{O}$ DNAse e RNAse livre e mais $60 \mu \mathrm{L}$ de isopropanol a 100\%, com posterior agitação (vórtex) por 15 segundos e incubação à temperatura ambiente por 15 minutos. Seguiu-se centrifugação (Eppendorf®, modelo 5804$\mathrm{R})(19.000 \mathrm{~g} \mathrm{x})$ por 30 minutos à temperatura de $4{ }^{\circ} \mathrm{C}$. O sobrenadante foi descartado e o restante do líquido por inversão do microtubo em papel de filtro. Posteriormente foi ressuspenso o sedimento com $150 \mu \mathrm{L}$ de isopropanol a 70\%, seguido de agitação (vórtex) por 15 segundos e centrifugação $(19.000 \mathrm{~g} \mathrm{x})$ por 10 minutos à temperatura de $4{ }^{\circ} \mathrm{C}$. Descartou-se o sobrenadante sendo a seguir esgotado o restante do líquido por inversão do microtubo em papel de filtro; subsequentemente os microtubos (sedimento) foram secos em uma centrifuga tipo speed vacuum (Eppendorf®, Alemanha) por 20 minutos à temperatura de $60{ }^{\circ} \mathrm{C}$. Acondicionaram-se os microtubos com sedimento à temperatura de $-20{ }^{\circ} \mathrm{C}$ até seu processamento (SAMBROOK et al., 1989).

As amostras secas foram ressolubilizadas em $10 \mu \mathrm{L}$ de formamida $\mathrm{Hi}$-Di (Applied Biosystems, USA) e submetidas a vigorosa agitação (vórtex) por 30 segundos. Subseqüentemente as amostras foram colocadas em uma microplaca, sendo a seguir desnaturadas a $95{ }^{\circ} \mathrm{C}$ durante 5 minutos e aplicadas em um seqüenciador automático (16 capilares), modelo ABI-3100 (Applied Biosystems®, Inc., Foster City, CA, USA). Foram utilizados parâmetros padronizados para injeção, e a separação eletroforética foi realizada com o uso do polímero POP6.

\subsection{Edição e alinhamento das seqüências da região VP1/VP2 do eritrovírus B19}

Após determinar as seqüências de nucleotídeos dos fragmentos da região VP1/VP2 amplificados pela reação de PCR, utilizando a técnica de seqüenciamento (seção 4.8), as mesmas foram alinhadas automaticamente com o programa Clustal $\mathrm{W}$, versão 1.4 
(THOMPSON et al., 1994). Também foi realizado o alinhamento manual, empregando-se o editor de seqüências BioEdit, versão 7.0.5 (HALL, 1999). Para o alinhamento de 117 novas seqüências (número de acesso: EF089178-EF089196, EF089198-EF089232 e EU142742EU142804) foram usadas amostras de eritrovírus publicadas no GenBank e classificadas dentro dos três genótipos propostos por Servant et al. (2002). Com número de acesso obtido no "GenBank" : 1) U31358, U38506, U38507, U38509, U38510, U38511, U38512, U38513, U38514, U38515, U38516, U38517, U38518 , U38546 , U53600, AB030673, AB030693, AB030694, B126262, AB126263, AB126264, AB126265, AB126267, AB126268, AB126271, AF162273, F161223, AF161224, AF161225, AF161226, AY386330, AY028237, M24682, M13178, Z68146, Z70560, Z70528, Z70599, NC000883 (genótipo 1); 2) AY044266, AY044268, AY064475, AY064476 (genótipo 2); AY083234, AY582124, AY647977 (genótipo 3), e do parvovirus símio (U26342). Os alinhamentos foram inspecionados e editados manualmente usando o programa Se-A1, Sequence Alignment editor v2.0a.11 (RAMBAUT, 1996).

\subsection{Análises filogenéticas}

Para a escolha do melhor modelo evolutivo foi utilizado o programa Modeltest v.3 (POSADA; CRANDALL, 1998). Este programa é usado para comparar de forma hierárquica diferente modelos de substituição de nucleotídeos, testando um conjunto de 56 modelos evolucionários, onde matrizes de distância filogenética são construídas utilizando-se os modelos possíveis.

Uma vez determinado o melhor modelo evolucionário, as reconstruções foram realizadas pelo programa PAUP v4.0b10 (SWOFFORD, 2003) empregando-se o método de máxima verossimilhança (MV) como critério de optimização. A visualização das reconstruções foi feita usando-se o programa Tree View. Versão 3.1 (RODERIC, 2000).

\subsection{Análise de seleção}

Para determinar se o vírus B19 está sob alguma pressão seletiva, diferentes métodos foram utilizados. Matrizes de distâncias pareadas foram estimadas para as $1^{\mathrm{a}}$ e $2^{\mathrm{a}}$ posições (maioria não-sinônimas), para as $3^{\text {as }}$ posições (maioria sinônimas) e para todas as posições, utilizando se o programa PAUP. Esses dados foram então plotados em um gráfico para que se pudesse avaliar se tais seqüências estavam evoluindo sob algum tipo de pressão seletiva; (i) seleção neutra: todas as posições dos códons evoluem da mesma maneira; (ii) 
seleção negativa ou purificadora: se as terceiras posições dos códons evoluem mais do que as primeiras e segundas posições; (iii) seleção positiva: se as terceiras posições dos códons estavam evoluindo menos que às demais.

Posteriormente foram obtidas as estimativas pareadas dos valores do teste de Tajima (1989) (D de TAJIMA) para as taxas de substituição sinônimas (dS) e não sinôminas $(\mathrm{dN})$ e então calculadas a razão dN/dS, utilizando-se o programa MEGA v.3.1 (KUMAR et al., 2004). Para as análises de distância pareadas foi utilizado o método de Li-Wu-Luo et al. (1985), com bootstrap de 1.000 replicatas.

Além do método de distância pareada, utilizamos a análise de seleção por verossimilhança, implantados nos programas CODEML, do pacote PAML (YANG, 1997) e HyPhy (POND, 2005). O método de verossimilhança usa a correção filogenética para descrever o processo de evolução dos códons, assim proporcionando maior confiabilidade ao sistema. A vantagem de utilizar esses programas é que a detecção de seleção positiva pode ser feita individualmente para cada um dos sítios (códons). O CODEML utiliza vários modelos evolutivos que diferem entre si na distribuição de $\mathrm{dN} / \mathrm{dS}$ (w) entre os códons. Os modelos empregados foram M0 (invariante), M1 (neutro), M2 (seleção positiva), M7 (dez categorias de códons com valores de distribuição beta) e o M8 que incorpora uma décima-primeira categoria em relação ao modelo M7. A detecção de seleção positiva ocorre se o modelo escolhido assumir valores de $\mathrm{dN} / \mathrm{dS}$ maiores que $1,(\mathrm{w}>1)$. Além disso, com o modelo M3 pode-se estimar o parâmetro alfa da distribuição gama, o que possibilita a incorporação de taxas de heterogeneidade entre os sítios. Com o programa HyPhy foi utilizado o modelo MG94xHKY85x3_4x2_rates, permitindo uma heterogeneidade de taxas, e o emprego de quatro categorias por taxa por parâmetro.

\subsection{Reconstrução das mudanças de aminoácidos}

A reconstrução das mudanças de aminoácidos ao longo das árvores (MV e MAP) foi realizada com o programa de MacClade 4.08 (MADDISON, D. R.; MADDISON, W. P., 2001), por meio do método de máxima parcimonia.

\subsection{Análise demográfica relativa ao B19 e D91.1}

As taxas de evolução e parâmetros demográficos nas populações de B19 e D91.1 foram estimadas por metodologia bayesiana de Monte Carlo, via cadeia de Markov. Este 
método está implementado no programa BEAST v1.3 (DRUMMOND; RAMBAUT, 2003). As seqüências, previamente datadas de acordo com o ano de coleta foram analisadas sob o modelo de substituição $\mathrm{HKY}+\mathrm{G}$, assumindo parâmetros como relógio molecular relaxado, e uma variedade de diferentes modelos demográficos (exponencial, logístico, de expansão e constante). Este programa também foi utilizado para a construção de uma árvore com a Maximum a posteriori (MAP).

\subsection{Análise estatística}

Os dados foram analisados com recursos do software Epi-Info (versão 6.0), Centers For Disease Control and Prevention, Atlanta, Geórgia, EUA, através do teste do quiquadrado $\left(\chi^{2}\right)$, com correções de MantelHaenszel, Yates e teste de Fisher. 


\section{RESULTADOS}

\subsection{Detecção do "status" sorológico e do ácido nucléico viral}

Um total de 487 amostras de soro ou plasma foi analisado, 349 (72\%) de Belém e $138(28 \%)$ de outras localidades (Anexo 1), de acordo com quatro grupos de manifestações clínicas associados às infecções causadas pelos eritrovírus, considerando duas faixas etárias: individuos $\leq 15$ e $>15$ anos de idade (Tabela 2). No grupo I, 70 (14\%) soros apresentaram anticorpos da classe IgM, sendo que 23 (5\%) deles com a presença de DNA; no grupo II, em 179 (37\%) amostras foram encontrados anticorpos IgM/IgG e 84 (17\%) delas com a presença de DNA; no grupo III, 114 (23\%) soros analisados mostraram níveis altos de anticorpos IgG e em $3(0,6 \%)$ deles a presença de DNA; no grupo IV, 124 (26\%) soros apresentaram ausência de anticorpos $\operatorname{IgM} / \operatorname{IgG}$ e em 7 (1,4\%) soros foi confirmada a presença de DNA. Em 117 (24\%) amostras foi confirmada presença de DNA, sendo que em 107 (22\%) delas foram detectados anticorpos IgM específicos do grupo eritrovírus. No grupo I, 59 amostras DNApositivas foram coletadas de indivíduos na faixa etária $\leq 15$ anos e 9 delas de indivíduos no grupo > 15 anos; no grupo II, 17 delas foram colhidas de indivíduos $\leq 15$ anos e 16 delas de individuos > 15 anos; no grupo III, 4 amostras DNA positivas foram colhidas de indivíduos $\leq$ 15 anos e 10 delas de indivíduos no grupo > 15 anos; e no grupo IV, apenas 2 amostras DNA positivas foram confirmadas nos indivíduos com $\leq 15$ anos (Tabela 2).

Tabela 2 - Detecção do "status" sorológico e detecção de ácido nucléico viral em amostras de pacientes da região amazônica infectados pelos eritrovírus, distribuídos por grupo clínico e faixa etária, no período de 1995 - 2005.

\begin{tabular}{|c|c|c|c|c|c|c|c|}
\hline \multirow[b]{2}{*}{$\begin{array}{l}\text { Grupo } \\
\text { Clínico }\end{array}$} & \multirow[b]{2}{*}{$\begin{array}{c}\text { Faixa } \\
\text { Etária } \\
\text { (em anos) }\end{array}$} & \multirow[b]{2}{*}{$\begin{array}{c}\text { Amostras } \\
\text { Testadas }\end{array}$} & \multicolumn{4}{|c|}{ “Status" sorológico/DNA ${ }^{+}$} & \multirow[b]{2}{*}{$\begin{array}{c}\text { Total } \\
\text { DNA }^{+}\end{array}$} \\
\hline & & & $\operatorname{IgM}^{+}$ & $\operatorname{IgM}^{+} / \mathrm{IgG}^{+}$ & $\mathrm{IgG}^{+}$ & IgM/IgG & \\
\hline \multirow[t]{2}{*}{$\mathrm{I}$} & $\leq 15$ & 171 & $37 / 12$ & $76 / 42$ & $14 / 1$ & $44 / 4$ & 59 \\
\hline & $>15$ & 36 & $5 / 1$ & $21 / 7$ & $5 / 0$ & $5 / 1$ & 9 \\
\hline \multirow[t]{2}{*}{ II } & $\leq 15$ & 96 & $13 / 4$ & $25 / 9$ & $19 / 2$ & $39 / 2$ & 17 \\
\hline & $>15$ & 92 & $4 / 2$ & $27 / 14$ & $39 / 0$ & $22 / 0$ & 16 \\
\hline \multirow[t]{2}{*}{ III } & $\leq 15$ & 19 & $4 / 1$ & $9 / 3$ & $6 / 0$ & $0 / 0$ & 4 \\
\hline & $>15$ & 48 & $3 / 1$ & $18 / 9$ & $22 / 0$ & $5 / 0$ & 10 \\
\hline \multirow[t]{2}{*}{ IV } & $\leq 15$ & 12 & $3 / 2$ & $1 / 0$ & $2 / 0$ & $6 / 0$ & 2 \\
\hline & $>15$ & 13 & $1 / 0$ & $2 / 0$ & $7 / 0$ & $3 / 0$ & 0 \\
\hline \multirow[t]{2}{*}{ Subtotal } & $\leq 15$ & 298 & $57 / 19$ & $111 / 54$ & $41 / 3$ & $89 / 5$ & 81 \\
\hline & $>15$ & 189 & $13 / 4$ & $68 / 30$ & $73 / 0$ & $35 / 2$ & 36 \\
\hline Total (\%) & & 487 & $70(14) / 23(5)$ & $179(37) / 84(17)$ & $114(23) / 3(0,6)$ & $124(26) / 7(1,4)$ & $117(24)$ \\
\hline
\end{tabular}




\subsection{Seqüenciamento e genotipagem}

De 487 amostras examinadas, 117 (24\%) confirmaram a presença de DNA. Estas 117 amostras foram sequienciados e posteriomente genotipados, sendo que 106 (91\%) foram identificados como genótipo 1 (B19 clássico) e 11 (9\%) como genótipo 3 (variante D91.1). No grupo clínico I (doenças exantemáticas), $53(45,3 \%)^{\mathrm{a}}$ e $9(7,7 \%)^{\mathrm{b}}$ foram identificados como genótipo 1 na faixa etária $\leq 15$ e $>15$ anos, respectivamente (a $v s$, p $<0,0001$ ) e 6 (5\%) como genótipo 3 em indivíduos $\leq 15$ anos. No grupo clínico II (desordens hematológicas), $16(13,7 \%)$ e $15(12,8 \%)$ foram identificados como genótipo 1 nas faixas etárias de $\leq 15$ e $>15$ anos, respectivamente, e $1(0,8 \%)$ foi identificado como genótipo 3 para cada grupo etário. No grupo clínico III (artropatias), $2(1,7 \%)^{\mathrm{c}}$ e $10(8,5 \%)^{\mathrm{d}}$ amostras foram identificados como genótipo 1 nas faixas etárias de $\leq 15$ e $>15$ anos, respectivamente ( c $v s$ d, $\mathrm{p}<0,001)$ e $2(1,7 \%)$ como genótipo 3 em individuos $\leq 15$ anos. No grupo clínico IV (outras condições clínicas associadas ao B19), foi identificado 1 isolado para cada genótipo na faixa etária $\leq 15$ anos (Tabela 3). No total de amostras analisadas não se detectou o genótipo 2.

\subsection{Relacionamento filogenético do genótipo 1 (B19) e genótipo 3 (D91.1)}

Cento e seis amostras se agruparam com o genótipo 1 (bootstrap, 100\%), mostrando divergência nucleotídica de 0 a 3,5\% (média de 1,1\%). Dentro do genótipo 1 foram encontrados três grupos distintos (A1, A2 e B), relacionadas ao eritrovírus B19. Outras 11 amostras se agruparam no genótipo 3 (bootstrap, 100\%), com diversidade genética de 0 a 1,6 $\%$ (média de $0,8 \%$ ). A diversidade nucleotídica entre as amostras destes dois genótipos foi de 12,8\%. O grupo A1 reuniu as manifestações clínicas de doenças exantemática (37 casos ), desordens hematológicas (13 casos ) e artropatia (7 casos). No grupo A2, a distribuição das manifestações clínicas foram 19, 6 e 3 casos, respectivamente. No grupo B, além de doença exantemática (7 casos), desordens hematológicas (11 casos) e artropatia (2 casos), foi encontrado 1 caso de miocardite. Além disso, entre amostras que agruparam com o genótipo 3, foi assinalado 1 caso de lúpus eritematoso sistêmico, 6 casos de doença exantemática, 2 de desordens hematológicas e 2 de artropatia (Figura 6). No grupo B foi encontrada uma alta proporção de casos de desordens hematológicas, 52\% (11/21) em comparação a assinalada para o grupo A (A1 e A2), 22\% (19/85), $\left(\chi^{2}=7,48, \mathrm{p}<0,006\right)$. 
Tabela 3 - Distribuição de genótipos (G1 e G3) de acordo com o grupo clínico e faixa etária, a partir de amostras DNA positivas de pacientes da região amazônica infectados pelos eritrovírus no período de 1995 - 2005

\begin{tabular}{|c|c|c|c|c|c|c|c|c|c|c|c|c|c|}
\hline \multirow[b]{3}{*}{$\begin{array}{l}\text { Grupo } \\
\text { clínico }\end{array}$} & \multirow[b]{3}{*}{$\begin{array}{c}\text { Faixa etária } \\
\text { (em anos) }\end{array}$} & \multicolumn{9}{|c|}{ “status" sorológico/Detecção de DNA/Genótipo } & \multirow{3}{*}{$\begin{array}{c}\begin{array}{c}\text { Total } \\
(\mathrm{N}=487)\end{array} \\
\text { DNA }^{+}\end{array}$} & \multirow{2}{*}{\multicolumn{2}{|c|}{$\begin{array}{c}\text { Total } \\
(\mathrm{N}=\mathbf{1 1 7})\end{array}$}} \\
\hline & & \multicolumn{3}{|c|}{$\operatorname{IgM}^{+}$} & \multicolumn{3}{|c|}{ IgG $^{+}$somente } & \multicolumn{3}{|c|}{ IgM $^{-} / \operatorname{IgG}^{-}$} & & & \\
\hline & & DNA $^{+}$ & G1 & G3 & DNA $^{+}$ & G1 & G3 & DNA $^{+}$ & G1 & G3 & & G1 & G3 \\
\hline \multirow[t]{2}{*}{$\mathrm{I}$} & $\leq 15$ & 54 & 48 & 6 & 1 & 1 & 0 & 4 & 4 & 0 & 59 & $53(45.3 \%)^{\mathrm{a}}$ & $6(5 \%)$ \\
\hline & $>15$ & 8 & 8 & 0 & 0 & 0 & 0 & 1 & 1 & 0 & 9 & $9(7.7 \%)^{b}$ & $0(0 \%)$ \\
\hline \multirow[t]{2}{*}{ II } & $\leq 15$ & 13 & 13 & 0 & 2 & 2 & 0 & 2 & 1 & 1 & 17 & $16(13.7 \%)$ & $1(0.8 \%)$ \\
\hline & $>15$ & 16 & 15 & 1 & 0 & 0 & 0 & 0 & 0 & 0 & 16 & $15(12.8 \%)$ & $1(0.8 \%)$ \\
\hline \multirow[t]{2}{*}{ III } & $\leq 15$ & 4 & 2 & 2 & 0 & 0 & 0 & 0 & 0 & 0 & 4 & $2(1.7 \%)^{\mathrm{c}}$ & $2(1.7 \%)$ \\
\hline & $>15$ & 10 & 10 & 0 & 0 & 0 & 0 & 0 & 0 & 0 & 10 & $10(8.5 \%)^{\mathrm{d}}$ & $0(0 \%)$ \\
\hline \multirow[t]{2}{*}{ IV } & $\leq 15$ & 2 & 1 & 1 & 0 & 0 & 0 & 0 & 0 & 0 & 2 & $1(0.8 \%)$ & $1(0.8 \%)$ \\
\hline & $>15$ & 0 & 0 & 0 & 0 & 0 & 0 & 0 & 0 & 0 & 0 & $0(0 \%)$ & $0(0 \%)$ \\
\hline Total & & 107 & 97 & 10 & 3 & 3 & $\mathbf{0}$ & 7 & 6 & 1 & $117(24 \%)$ & $106(91 \%)$ & $11(9 \%)$ \\
\hline
\end{tabular}

Nota: $\mathrm{I}$ = doença exantemática; II = desordens hematológicas; III = artropatias; IV = outras condições clínicas; G1 = genótipo 1; G3 = genótipo 3; a $v s \mathrm{~b}=\mathrm{p}<0,0001 ; \mathrm{c} v s \mathrm{~d}=\mathrm{p}<0,001$. 


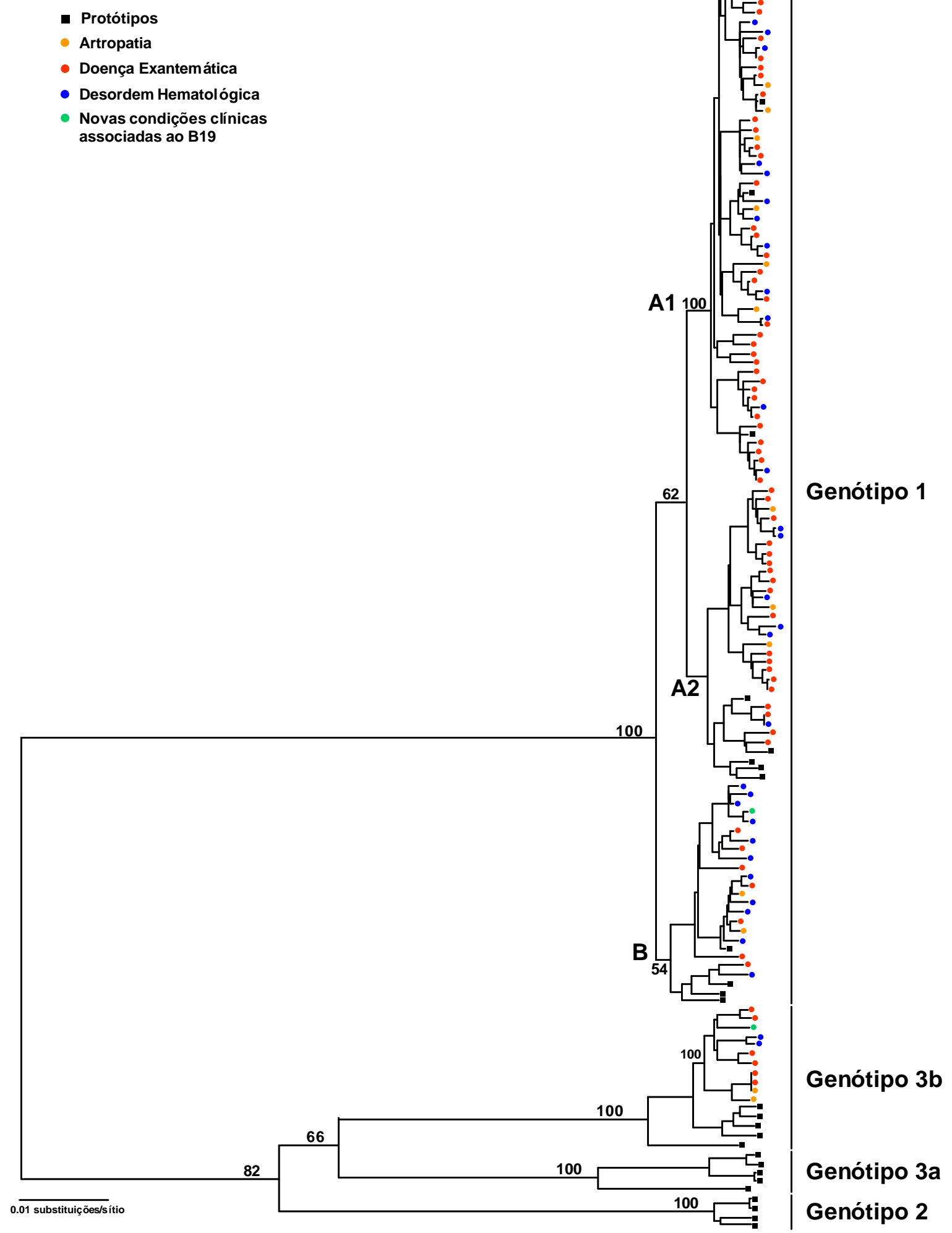

Figura 6 - Arranjo filogenético mostrando a distribuição de genótipos (G1 e G3) em três diferentes grupos, de acordo com o tipo de manifestação clínica, a partir de amostras de DNA positivas detectadas em pacientes da Amazônia, no período de 1995 - 2005. 


\subsection{Filogenia do B19 e o modelo "panela de pressão"}

No total foram sequienciados 476 pares de bases de 46 amostras de pacientes da Amazônia (maioria de Belém, Pará) coletadas entre 1995-2005. Além disso, analisaram-se mais 48 seqüências procedentes dos pacientes de São Paulo (1990-2003), bem como 39 seqüências procedentes do GenBank (1973-2003). A árvore MAP com comprimento de ramos corrigidos por tempo de isolamento é mostrada na Figura 7 (seqüências do grupo externo foram removidas para aumentar a resolução). Usando o método de MV foi obtida a mesma topologia (dados não mostrados). As seqüências de Belém (mostradas em cor magenta na Figura 7) estão distribuídas ao longo da árvore, sendo que a maioria agrupa-se em três linhagens principais (mostradas por números seguido do símbolo *). O grupo $1^{*}$ foi largamente composto de sequiências obtidas do Brasil (inclusive Belém), indicando uma permuta significante destes vírus dentro do território brasileiro, embora também contenha 4 sequiências oriundas de outros locais uma de 1994, dos Estados Unidos da América (U38515/US), outro de 2001 da Suécia (AY028237/SW), um da Alemanha (Z70528/GE) de 1994 e um isolado da Finlândia (AF161224/FI) de 1996. Em contraste, os grupos $2^{*}$ e $3 *$ são predominantemente constituídos por linhagens da Amazônia/Belém e sugerem introduções independentes de linhagens do hemisfério norte na Amazônia (embora o tamanho da amostragem não permita excluir que a introdução inicial pode ter sido oriunda da região Sudeste do Brasil). Não obstante, ambos os exemplos sugerem a introdução independente de linhagens de B19, genótipo 1, na região Amazônica. Para confirmar formalmente tais entradas independentes foi realizado o teste de Shimoidara-Hasegawa, que compara árvores com diferentes topologias. Na aplicação desse teste foram utilizadas duas árvores distintas, a primeira com diferentes introduções na região amazônica (log likelihood= -2721.907) e a segunda envolvendo amostras de Belém "forçadas" a se tornar monofiléticas (log likelihood= -2758.270), o que implicaria em um único evento de introdução. A diferença em probabilidade de 36.363 foi expressiva $(\mathrm{p}=0,045)$, apoiando a hipótese de múltiplas e independentes introduções de linhagens do genótipo 1 dentro da região Amazônica.

A Figura 7 descreve as reconstruções mais parcimoniosas (MPRs) na árvore do MAP, mostrando o excesso de mudanças não-sinônimas ao longo da radiação independente de linhagens de Belém. Os sítios 4, 27, 72 e 105 mudaram independentemente dentro dos agrupamentos, enquanto o sítio 155 foi compartilhado por um grupo de três seqüências, sugestivo de possível propagação entre a população humana. Um único sítio que codifica uma lisina no códon 19 (mostrado em amarelo na Figura 7) foi compartilhado por Belém (uma 
vez) e Cosmopolitas (duas vezes). Além do códon 19, nenhum outro sítio aparece mais de uma vez nas seqüências Cosmopolita.

\subsection{Diferentes taxas de substituição entre os vírus B19}

Considerando que a análise filogenética sugeriu introduções independentes do vírus B19 na região amazônica, nós dividimos as seqüências em 2 grupos - Amazônia/Belém e Cosmopolitas (ex. todas as seqüências procedentes de outros locais, inclusive São Paulo), com propósito de determinar se estas diferem em dinâmica evolucionária. Primeiro, para obter uma avaliação gráfica dos dados procuramos explorar padrões de divergência genética nas diferentes posições dos códons. Isto revelou distâncias mais elevadas nas $1^{\mathrm{a}}$ e $2^{\mathrm{a}}$ posições dos códons de B19 em Belém, quando comparados à população Cosmopolita, como indicado pelos declives de regressões na Figura 8. Em marcante contraste, as $3^{\mathrm{a}}$ posições dos códons de B19 isolados em Belém tinham níveis menores de diversidade genética que aqueles das seqüências Cosmopolitas (Figura 8). Este padrão altamente distintivo indica que o B19 na Amazônia/Belém apresenta uma taxa mais alta de substituições não-sinônimas que aqueles vírus isolados em outras localidades, além disso, pode-se observar que os níveis de diversidade genética em sítios sinônimos estão consistentemente reduzidos. 


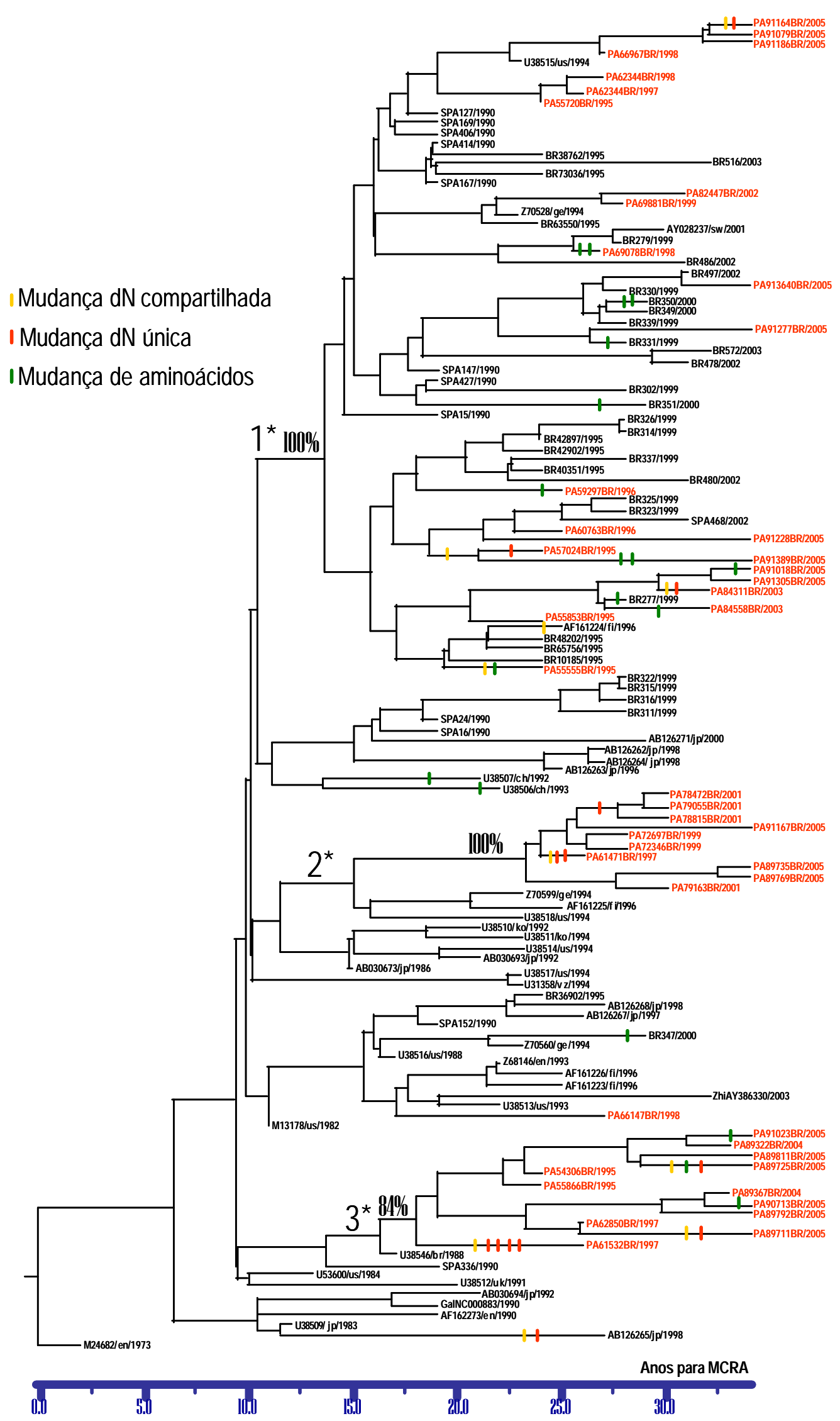

Figura 7 - Árvore Maximum a posteriori (MAP) para 133 sequências da região comum parcial VP1/VP2 (476pb) do parvovírus humano B19. 


\subsection{Pressão seletiva}

Para adicional avaliação dos processos evolucionários atuando sobre o B19 em Belém, foram calculados os valores estatísticos relativos ao D de Tajima (TAJIMA, 1989) o qual testa a hipótese nula de evolução neutra. Valores negativos relativos ao D de Tajima sugerem que uma seleção positiva possa estar atuando em uma população. Novamente, um padrão sobremaneira diferente foi observado entre Belém e as populações Cosmopolitas: (i). A Cosmopolita inclue seqüências de Erdman et al. (1996), bem como do Hospital Universitário da cidade de São Paulo; $\mathrm{D}=-0,8776$, S.E. $=-0,0455$ (87 seqüências, 10 segregando aminoácidos) e de (ii) isolados da Amazônia/Belém; D= -4,1684, S.E. = -1,6532 (46 seqüências, 24 sítios segregando aminoácidos). O valor fortemente negativo do $\mathrm{D}$ de Tajima obtido para seqüências de Belém suporta a idéia de que o aumento na diversidade genética nas $1^{\mathrm{a}}$ e $2^{\mathrm{a}}$ posições dos códons está relacionado com um desvio de evolução neutra. Resultados similares foram obtidos por meio de uma análise das taxas relativas de substituições por sítio sinônimos (dS) e não-sinônimos (dN). Neste caso, dN foi 3,9 vezes maior em Belém $(\mathrm{dN}=0,0043 \pm 0,0011)$ comparada com seqüências de outros locais $(\mathrm{dN}=$ 0,0011 \pm 0,003). Entretanto, não houve diferença significante em dS entre populações; Cosmopolitas, $\mathrm{dS}=0,0548 \pm 0,0105$ e Belém, $\mathrm{dS}=0,0490 \pm 0,0139$.

A investigação subseqüente determinou se a pressão seletiva agindo em diferentes sítios de códons poderia estar associada à diferença entre as populações de Belém e Cosmopolita. Utilizando o método CODEML não foram encontradas evidências de seleção positiva em nenhum códon individual nas seqüências de Belém ou Cosmopolita, visto que os modelos neutros de evolução de códons não puderam ser rejeitados pelos modelos mais complexos que apóiam seleção positiva. Entretanto, esta análise também indicou que 15 códons dos B19 isolados de Belém possuíam valores elevados de dN/dS, com uma razão média de 1,50. Mais adiante foram detectados 6 desses sítios não-sinônimos sujeitos a fraca seleção positiva no HyPhy (valores do fator de Bayes < 20) com uma razão média dN/dS de 1,70. Em contraste, o CODEML detectou 4 sítios no grupo Cosmopolita com uma elevada razão média de dN/dS de 2,25, três dos quais foram também observados no HyPhy, porém com baixa razão média dN/dS de 1,10. Considerados conjuntamente, os dados denotam uma elevação na taxa de sítios não-sinônimos entre as linhagens do B19 oriundas de Belém, sendo que várias destas podem possivelmente estar sob seleção positiva, embora esta última conclusão necessite de confirmação em uma amostra maior de seqüências. 


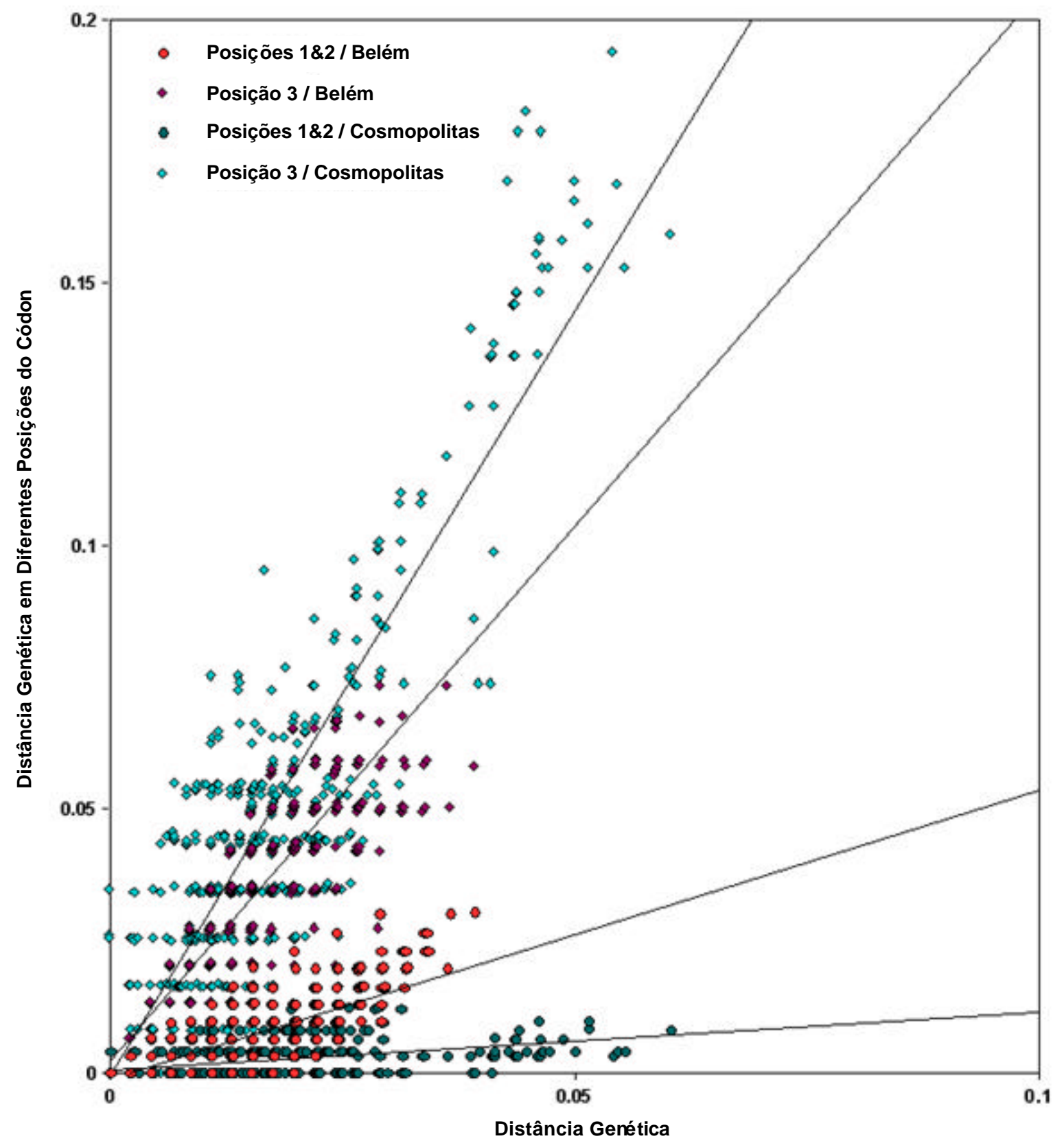

Figura 8 - Comparação da distância genética nas $1^{\mathrm{a}}, 2^{\mathrm{a}}$ e $3^{\mathrm{a}}$ posições do códon versus a distância genética total, entre regiões comuns VP1/VP2 de parvovírus humanos B19. As linhas de regressão indicam que as sequências de Belém têm uma alta taxa de substituição nas $1^{\mathrm{a}}$ e $2^{\mathrm{a}}$ posições, em comparação com sequências cosmopolitas (i.e. todas as outras sequências que não são de Belém), mas uma baixa taxa de substituição na $3^{\mathrm{a}}$ posição do códon. 


\subsection{Dinâmica populacional}

Para investigar outros aspectos na dinâmica de população do B19 na Amazônia e populações Cosmopolitas, nós estimamos vários parâmetros populacionais usando o método Bayesiano de coalescência disponível no pacote BEAST.

A Tabela 4 mostra que o B19 parece experimentar taxas evolucionárias equivalentes em todas as populações, apresentando no modelo logístico, taxas similares de crescimento e tempo de duplicação ( ). Para todos os grupos as taxas de substituição de nucleotídeos apresentaram valores de HPD sobrepostos, com uma taxa média para linhagens de Belém da ordem de 2,572 x $10^{-4}$ substituições/sítios/ano e para isolados Cosmopolitas de $1,9 \times 10^{-4}$ substituições/sítios/ano. Estes resultados são similares aos calculados por Shackelton e Holmes (2006). A datação de populações do B19 mostrou uma coalescência média de 45 anos para as três diferentes linhagens do genótipo 1 na Amazônia, e para São Paulo e Cosmopolitas, de 73 e 66 anos, respectivamente.

A Tabela 5 mostra a taxa evolucionária e datas de divergência relativas ao genótipo 3. O crescimento logístico foi empregado como melhor modelo de ajuste demográfico. A taxa média de substituições de nucleotídeos foi de 1,20 x 10 $0^{-3}$ (95\% HPD de $3,10 \times 10^{-4}$ a 2,32 $\times 10^{-3}$ ). Encontrou-se uma taxa média de idade (anos) de MRCA para todas as sequiências do genótipo 3 de 36 anos (95\% HPD de 14 a 52 anos) e, para os subtipos 3 a e 3 b foram de 21 anos (95\% HPD de 10 a 41 anos) e 28 anos (95\% HPD de 14 a 49 anos), respectivamente. A taxa média de idade de MRCA para o genótipo $3 b$ em sequências de Belém foi de 19 anos ( 95\% HPD de 9 a 38 anos). 
Tabela 4 - Estimativa Bayesiana da dinâmica de população e parâmetros evolucionários para B19 em amostras do mundo (Cosmopolitas), Belém (Amazônia) e da cidade de São Paulo.

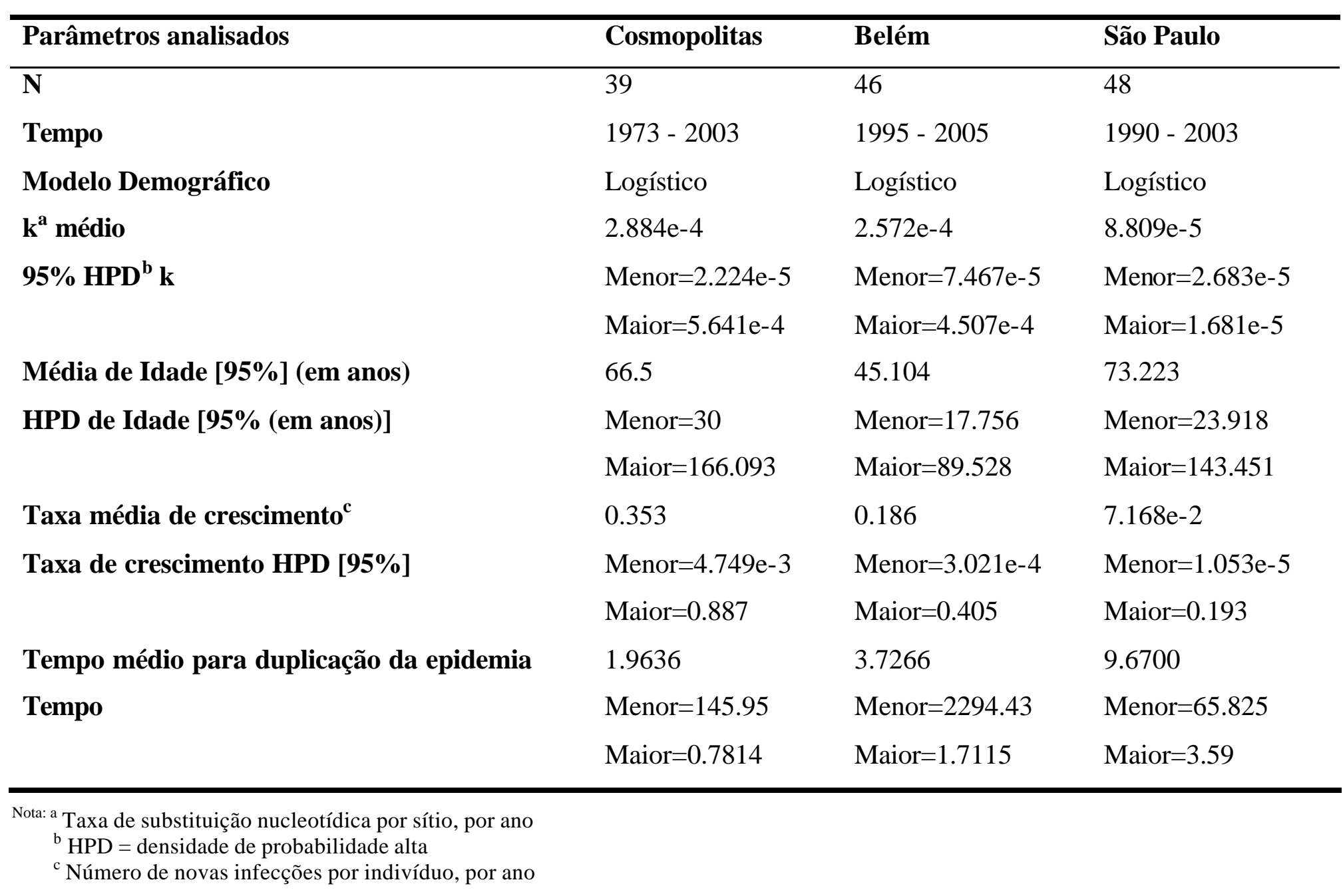


Tabela 5 - Estimativa Bayesiana da dinâmica de população e parâmetros evolucionários para a variante D91.1 em amostras do mundo e Belém

\begin{tabular}{|c|c|c|c|c|}
\hline \multirow[b]{2}{*}{ Parâmetros analisados } & \multicolumn{4}{|c|}{ Genótipo } \\
\hline & Tipo 3 & $\mathbf{3 a}$ & $\mathbf{3 b}$ & 3b Belém \\
\hline No. de amostras & 21 & 5 & 16 & 11 \\
\hline Período de coleta & $1991-2005$ & $1995-2005$ & $1991-2004$ & $1997-2003$ \\
\hline Modelo de Relógio Molecular & Relaxed & NA & NA & NA \\
\hline Melhor Modelo Demográfico & Logistic growth & NA & NA & NA \\
\hline Taxa de Substituiçãoo ${ }^{a}\left(95 \% H P D^{b}\right)$ & $\begin{array}{c}1.20 \times 10^{-3} \\
\left(3.10 \times 10^{-4} \text { to } 2.32 \times 10^{-3}\right)\end{array}$ & NA & NA & NA \\
\hline Média de idade (anos) de MRCA ${ }^{c}(95 \%$ HPD) & $36(14-52)$ & $21(10-41)$ & $28(14-49)$ & $19(9-38)$ \\
\hline $\begin{array}{l}\text { Taxa média de crescimento da população } \\
(95 \% \text { HPD) }\end{array}$ & $\begin{array}{c}3.89 \\
\left(1.034 \times 10^{-4} \text { to } 9.228\right)\end{array}$ & NA & NA & NA \\
\hline Média de tempo de duplicação epidêmica $(\lambda)^{e}($ anos $)$ & 5.44 & NA & NA & NA \\
\hline
\end{tabular}

Nota:

${ }^{a}$ Número médio de substituições nucletídicas per sítio, per ano.

${ }^{b}$ Densidade de probabilidade alta.

${ }^{c}$ MRCA (most recent common ancestor), ancestral comum mais recente.

${ }^{\mathrm{d}}$ Número médio de novas infecções per hospedeiro, per ano.

${ }^{\mathrm{e}}$ Tempo necessário para o número efetivo de infecções duplicar $(\lambda=\ln (2) / \mathrm{r}$, onde $\mathrm{r}=$ taxa de crescimento).

NA, Não Aplicável. 


\section{DISCUSSÃO}

Neste estudo foi analisado um fragmento de $476 \mathrm{pb}$ que codifica uma parte das regiões VP1 e VP2, o que possibilitou identificar os genótipos descritos para o gênero Eritovírus. De acordo com a recente reclassificação proposta (SERVANT et al., 2002), nossas amostras foram identificados dentro de dois genótipos: 1 (B19-relacionados) e 3 (D91.1relacionados), envolvendo quatro grupos distintos de manifestações clínicas. Até agora, somente um limitado número de estudos tem relatado a presença dos genótipo 1 (B19 clássico) e 3 (variante D91.1) em países de climas temperado e tropical (HEEGAARD et al., 2001; SANABANI et al., 2006; SERVANT et al., 2002; TOAN et al., 2006a). No Brasil, o primeiro estudo particularizando a identificação dos genótipos de eritrovírus foi conduzido por Sanabani et al. (2006), na cidade de São Paulo, região Sudeste. Na Amazônia, este é o primeiro relato que assinala a presença dos genótipos de eritovírus indicando a circulação conjunta da variante D91.1 e linhagens do vírus B19. Nossos resultados mostraram uma predominante circulação do genótipo 1 (91\%), comparada à baixa freqüência do genótipo 3 em nossa região. Coube a Toan et al. (2006) observar tal fato previamente para o genótipo 1 (97\%) e Servant et al. (2002) quanto ao 3 (11.4\%) no Vietnã e França, respectivamente. Essa alta freqüência do genótipo 1 pode estar relacionada a uma introdução mais antiga das linhagens do eritrovírus B19 na região amazônica, com média de 45 anos (FREITAS et al., 2007). Esta situação tem suporte na mais recente introdução da variante D91.1 (genótipo 3) em nossa região, há 19 anos em média, e, ao redor de 36 anos para outras localidades. Além disso, estudos realizados por Freitas et al. (1990; 1993) já haviam registrado a circulação do eritrovírus B19 em espécimes clínicos colhidos de comunidades indígenas isoladas da Amazônia (1975), bem como de áreas urbanas (1988, 1990, 1993). O genótipo 2 não foi encontrado entre as amostras analisadas no período entre 1995 e 2005. Nossos planos residem em determinar se o mesmo circula entre populações amazônicas, já que foi encontrado em parte da região sudeste do Brasil entre pacientes portadores de desordens hematológicas (SANABANI et al., 2006).

No tocante às manifestações clínicas, foi observada uma elevada freqüência do genótipo 1 no grupo de doenças exantemáticas, sendo mais expressiva entre crianças $(45,3 \%)$ que a encontrada em adultos $(7,7 \%)$. Por outro lado foi assinalada uma alta freqüência do genótipo 1 em pacientes portadores de manifestações articulares, mais expressiva em adultos $(8,5 \%)$ que nas crianças $(1,7 \%)$ do mesmo grupo clínico, mostrando nas duas situações uma diferença estatisticamente significativa com $\mathrm{p}<0,0001$ e $\mathrm{p}<0,001$, respectivamente. Em 
contraste, freqüências similares em crianças $(13,7 \%)$ e adultos $(12,8 \%)$ foram registradas no grupo clínico dos pacientes portadores de desordens hematológicas, configurando uma irregular distribuição do genótipo 1 (B19 clássico) nos três distintos grupos de manifestações clínicas mencionados. Tais características distintas, diga-se de passagem, previamente relatadas por Servant et al. (2002) quando examinaram grupos de pacientes com diferentes sintomas. Observamos ainda uma predominante freqüência do genótipo 1 em relação ao sexo feminino, em três dos quatro grupos clínicos analisados (dados não exibidos). Este fato já havia sido descrito por Freitas et al. (2002) em um estudo envolvendo mulheres portadoras de manifestações articulares associadas à infecção pelo B19 na região amazônica.

No caso do genótipo 3 foi observada maior diversidade clínica que a encontrada na literatura científica (SERVANT et al., 2002; SANABANI et al., 2006), bem como uma irregular distribuição nos grupos de manifestações clínicas, tal como previamente descrito por Servant et al. (2002), sendo que a mais expressiva frequiência foi encontrada em crianças com doença exantemática (5\%). Em contrapartida, observou-se uma baixa frequiência em adultos portadores de desordens hematológicas. Nesse caso existe uma aparente diferença entre nossos resultados e aqueles de prévios relatos que observaram uma alta frequiência do genótipo 3 em pacientes adultos do mencionado grupo clínico NGUYEN et al., 1999; SANABANI et al., 2006; SERVANT et al., 2002). Entre os casos associados à infecção pelo genótipo 3 (variante D91.1) identificou-se um paciente portador de lúpus eritematoso sistêmico, porém não foi possível estabelecer uma relação entre o citado genótipo e o tipo especifico de manifestação clínica, haja vista sua associação com diferentes apresentações clínicas.

A recente classificação do genótipo 3 em subtipos $3 \mathrm{a}$ e $3 \mathrm{~b}$, proposta por Parsyan et al. (2007), ensejou demonstrar-se uma elevada circulação do subtipo 3a nessa investigação, a qual envolveu pacientes de Gana. Nossos resultados mostraram uma situação inversa, com predominância do subtipo $3 \mathrm{~b}$ entre pacientes habitantes da região amazônica. Tal situação pode estar relacionada a uma particular distribuição destas linhagens em áreas geográficas distintas (SERVANT et al.; 2002; ERDMAN et al., 1996). A relevância clínica desses subtipos, sua distribuição mundial e diferenças na esfera molecular ainda estão por ser estabelecidas.

No presente estudo foram observados três grupos distintos (A1, A2 e B) entre as amostras do genótipo 1, sendo que todos os grupos apresentaram introduções independentes na região amazônica, como previamente descrito por Freitas et al. (2007). No caso particular 
do grupo B foi observada uma elevada proporção de pacientes portadores de desordens hematológicas (52\%), comparada a uma baixa freqüência (22\%) no grupo A (A1 e A2), $\left(\chi^{2}=\right.$ $7,48, \mathrm{p}<0.006$ ). Vale ressaltar que todas as amostras do grupo B envolvendo pacientes com desordens hematológicas procederam de banco de sangue, a maioria coletada entre 2004 e 2005. A análise conjunta desses resultados sugere a ocorrência de infecções recentes relacionadas à mesma linhagem de eritrovírus B19, provavelmente uma amostra de doador assintomático como a que agrupou com as nossas amostras do grupo $\mathrm{B}$, o protótipo U38546/BR/1988 identificado por Erdman et al., 1996. Como relevante cabe mencionar que não existe exame de rotina para o diagnóstico do eritrovírus B19 em bancos de sangue do Brasil, e que além da via respiratória de transmissão o eritrovírus B19 pode ser disseminado via uso.de produtos derivados do sangue (BEERSMA et al., 2005).

As sequiências do genótipo 1 e 3 b exibiram uma diversidade genética média de $1,1 \%$, e $0,8 \%$, com distância nucleotidica entre os dois genótipos de 12,8\%. Esses valores são consistentes com aqueles previamente descritos para estes genótipos quando se analisa a mesma região do gene VP1 e VP2 (PARSYAN et al., 2007; TOAN et al., 2006a; SERVANT et al., 2002). Registramos um baixo grau de variabilidade (0 a 1,6\%) entre nossas amostras pertencentes ao genótipo 3b, quando comparadas com base nos fragmentos das mesmas regiões VP1 e VP2 analisados por Parsyan et al. (2007). Esta aparente baixa variabilidade de nossas sequências pode estar relacionada a uma única introdução do genótipo $3 b$ na Amazônia, seguida por disseminação na população. Na realidade, o efeito fundador (conjunto de todos os genes presentes em uma população) é um evento muito freqüente dentro da evolução viral. A baixa diversidade genética apresentada pela variante D91.1 (média de 0,8\%) sugere sua recente introdução na região Amazônica.

A taxa média de $1,2 \times 10^{-3}$ substituição nucleotidica/sitio/ano para o total de sequências do genótipo 3 foi mais alta que a previamente descrita para o genótipo 1 (SHACKELTON, HOLMES, 2006; FREITAS et al., 2007) e 3a (PARSYAN et al., 2007). Esta taxa foi utilizada para o cálculo do tempo de evolução do genótipo 3 e o MRCA deste genótipo foi estimado em 36 anos (95\% HPD de 14 a 52 anos). Este resultado difere do MRCA previamente estimado por Parsyan et al. (2007), que encontrou um MRCA de 525 anos. Não obstante, existe sobreposição dessa estimativa à encontrada em nosso estudo, dado que os 95\% HPD abrangem entre 43,5 e 1993 anos e, portanto, a conciliação dessas estimativas. Entretanto, nossas estimativas sugerem uma mais recente introdução para o genótipo 3b na região amazônica, média de 19 anos (95\% HPD de 9 a 38 anos). A diversidade 
genética de nossas sequências do genótipo 3 b na Amazônia (média 0,8\%, de 0 a 1,6\%) foi consistente com a estimativa de introdução recente, já que é três vezes menor que a encontrada por Parsyanet al. (2007), média de 2,72 (de 0,84 a 4,26\%).

O mais notável desses resultados é que essas linhagens de B19 introduzidas independentemente na Amazônia tenham experimentado uma elevada taxa de substituições não-sinônimas. Como não encontramos qualquer característica na dinâmica epidemiológica viral consistente com este padrão, postulamos que a população hospedeira, particularmente em termos de pressão seletiva, represente o fator diferencial e denote uma explicação provável para estas elevadas taxas.

A prevalência do B19 na América do Sul encontra-se ao redor de 50\% (ABARCA et al., 2002; ANDERSON et al., 1986; COHEN; BURKLEY, 1988; GAY et al., 1994; LISBOA, 1997; NUNOUE et al., 1985), a qual condiz com valores obtidos globalmente. O eritrovírus B19 é endêmico na região Amazônica e pode sofrer flutuações na incidência a intervalos que variam de 3 a 5 anos (FREITAS et al., 1993). Com efeito, registrou-se um aumento na prevalência de 43\% para 85\% entre 1990 e 2002 em Belém (FREITAS et al., 2002). Atualmente, a prevalência na cidade de Belém é situa-se em aproximadamente $70 \%$ mais alta que outras regiões.

Das considerações acima formuladas um cenário evolutivo plausível para o B19 na região Amazônica seria a reintrodução de diferentes linhagens virais ao longo do tempo, as quais devem negociar, por meio de evolução adaptativa, com níveis altos de imunidade adquiridos pelo contato do hospedeiro com as linhagens pré-existentes. Sob este tipo de pressão seletiva, as linhagens do B19 presentes em Belém deveriam apresentar um aumento no número de substituições não-sinônimas por meio de evolução adaptativa, para facilitar reinfecções consecutivas. Além disso, uma vez que na Amazônia a densidade demográfica da população hospedeira é menor que a de outras regiões e das quais recebe novas linhagens, uma pequena rede de transmissão previne o acúmulo de diversidade genética nas posições sinônimas devido a constantes varreduras seletivas, refletidas nas mudanças de diversidade genética da $1^{\mathrm{a}}$ e $2^{\mathrm{a}}$ posição do códon. Consequentemente, propomos que a região amazônica atue como uma "panela de pressão" para a geração de diversidade do vírus B19, visto que mudanças não-sinônimas são muito mais freqüentes nesta região. É claramente importante determinar se o B19 encontra-se submetido à pressão similar em outras regiões do mundo, compartilhando condições semelhantes com Belém, ou se outros patógenos endêmicos na Amazônia exibem padrão evolutivo similar. 
Em síntese, identificamos dois genótipos, 1 e 3b, circulando na Amazônia brasileira e três grupos distintos relacionados ao genótipo 1, co-circulando ao longo de 10 anos. As análises filogenéticas levadas a efeito em nossos estudos reforçam que as linhagens do B19 não estão associadas com enfermidade clínica específica, mas inerentes ao hospedeiro como descrito previamente por Erdman et al. (1996). Em estudos adicionais pretendemos continuar o monitoramente da ocorrência dos eritrovírus na região amazônica, incluindo a possível emergência do genótipo 2. É importante introduzir rotina de detecção do eritrovírus B19 em bancos de sangue do sistema de saúde brasileiro. Nossos resultados indicam que além da via respiratória pode estar havendo transmissão continua pela administração de produtos derivados do sangue para pacientes susceptíveis. 


\section{CONCLUSÕES}

- A casuística selecionada foi fundamental para encontrarmos um número elevado de infecções recentes (presença de $\operatorname{IgM}^{+} / \operatorname{IgG}^{+}$) e recentes/ativas (presença de $\operatorname{IgM}^{+} / \mathrm{IgG}^{+}$mais DNA), o que possibilitou o desenvolvimento do estudo no âmbito da região amazônica (1995-2005);

- A caracterização molecular das amostras permitiu identificar a presença do genótipo $1 \mathrm{e}$ 3, sendo, no caso deste último, o primeiro registro na região amazônica, bem como ausência do genótipo 2 do grupo eritrovírus no período sob investigação;

- A datação das amostras denotou uma antiga circulação para o genótipo 1 e introdução mais recente no tocante ao genótipo 3 na região amazônica;

- A análise filogenética permitiu identificar três linhagens distintas dentro do genótipo 1 (A1, A2 e B), com introduções independentes na região amazônica;

- A análise da distribuição etária relativa ao genótipo 1 mostrou uma alta freqüência entre crianças e adultos em três dos quatros grupos clínicos investigados; para o genótipo 3 maior freqüência em crianças com doença exantemática que adultos portadores de desordens hematológicas, esta representando a associação clínica mais freqüentemente relatada na literatura científica;

- A análise filogenética relativa aos nossos genótipos 3 mostrou que os mesmos se classificam no grupo 3b, recentemente proposto e com introdução única em nossa região;

- Análise relativa aos pacientes portadores de desordens hematológicas dentro do grupo B sugere que os mesmos foram recentemente infectados pela mesma linhagem do B19, genótipo 1, e com provável trans missão via derivados do sangue;

- Nossa análise demonstrou mais ampla diversidade clínica para as amostras agrupadas no genótipo 3b, do que a previamente descrita na literatura mundial;

- Não foi possível comprovar o envolvimento das linhagens circulantes com um tipo específico de manifestação clínica nos quatro grupos clínicos investigados;

- As diversidades genéticas das sequiências referentes aos genótipos 1 e 3 foram similares às previamente descritas na literatura mundial para o fragmento da região VP1 e VP2 do grupo eritrovírus;

- A análise filogenética em amostras do genótipo 1 mostrou que as três linhagens, introduzidas independentemente na Amazônia, apresentaram uma elevada taxa de substituições não-sinônimas se comparadas àquelas encontradas nas regiões Cosmopolitas; 
- A análise relativa à dinâmica epidemiológica viral não mostrou um padrão consistente capaz de explicar a elevada taxa de substituições não-sinônimas;

- Para explicar a ocorrência mais freqüente de mudanças não-sinônimas nas sequiências gênicas da região amazônica, propôs-se o modelo da "panela de pressão" evolucionária, onde as linhagens têm que "negociar" por meio de evolução adaptativa, com níveis altos de imunidade, ou seja, a necessidade de infectar e reinfectar uma população numericamente limitada de susceptíveis. 


\section{REFERÊNCIAS}

ABARCA, K.; COHEN, B. J.; VIAL, P. A. Seroprevalence of Parvovirus B19 in urban chilean children and young adults, 1990 and 1996. Epidemiol. Infect., v. 128, n. 1, p. 59-62, 2002 .

ADLER, S. P.; MANGANELLO, A. M.; KOCH, W. C.; HEMPFLING, S. H.; BEST, A. M. Risk of human parvovirus B19 infections among school and hospital employees during endemic periods. J. Infect. Dis., v. 168, n. 2, p. 361-368, 1993.

ALLANDER, T.; TAMMI, M. T.; ERIKSSON, M.; BJERKNER, A.; TIVELJUNGLINDELL, A.; ANDERSON, B. Cloning of a human parvovirus by molecular screening of respiratory tract samples. Proc. Natl. Acad. Sci. USA., v. 102, n. 36, p. 12891-12896, 2005.

ANDERSON, L. J. Human parvovirus B19. Pediatr. Ann., v. 19, n. 9, p. 509-510, 512-513, 1990b.

ANDERSON, L. J. Role of parvovirus B19 in human disease. Pediatr. Infect. Dis. J., v. 6, n. 8, p. 711-718, 1987.

ANDERSON, L. J.; GILlESPIE, S. M.; TOROK, T. J.; HURWITZ, E. S.; TSOU, C. J.; GARY, G. W. Risk of infection following exposures to human parvovirus B19. Behring Inst. Mitt., v. 85, p. 60-63, 1990a.

ANDERSON, L. J.; HURWITZ, E. S. Human parvovirus B19 and pregnancy. Clin. Perinatol., v. 15, n. 2, p. 273-286, 1988.

ANDERSON, L. J.; TSO, C.; PARKER, R. A.; CHORBA, T. L.; WULFF, H.; TATTERSALL, P.; MORTIMER, P. P. Detection of antibodies and antigens of human parvovirus B19 by enzyme-linked immunosorbent assay. J. Clin. Microbiol., v. 24, n. 4, p. 522-526, 1986.

ANDERSON, M. J. Human parvovirus infection. J. Virol. Methods, v. 17, n. 1/2, p. 175$181,1987 b$.

ANDERSON, M. J. Parvoviruses as agents of human disease. Prog. Med. Virol., v. 34, p. 5569, 1987a.

ANDERSON, M. J.; DAVIS, L. R.; HODGSON, J.; JONES, E.; MURTAZA, L.; PATTISON, J. R.; STROUD, C. E.; WHITE, J. M. Occurrence of infection with a parvovirus-like agent in children with sickle-cell anaemia duringa two-year period. J. Clin. Pathol., v. 35, n. 7, p. 744-749, 1982.

ANDERSON, M. J.; HIGGINS, P. G.; DAVIS, L. R.; WILLMAN, J. S.; JONES, S. E.; KIDD, I. M.; PATTISON, J. R.; TYRRELL, D, A. Experimental parvoviral infection in humans. J. Infect. Dis., v. 152, n. 2, p. 257-265, 1985.

ANDERSON, M. J.; LEWIS, E.; KIDD, I. M.; HALL, S. M.; COHEN, B. J. An outbreak of erythema infectiosum associated with human parvovirus infection. J. Hyg., London, v. 93, n. 1, p. 85-93, 1984. 
ARACTINGI, S.; BAKHOS, D.; FLAGEUL, B.; VÉROLA, O.; BRUNET, M.; DUBERTRET, L.; MORINET, F. Immunohistochemical and virological study of skin in the papular-purpuric gloves and socks syndrome. Br. J. Dermatol., v. 135, n. 4, p. 599-602, 1996.

ASTELL, C. R. Structure of terminal hairpins and their role in replication of parvovirus genomes. In: TIJSSENS, P. (Ed.). Handbook of parvoviruses. Boca Raton: CRC Press, 1990. p. 59-79.

ASTELL, C. R.; LUO, W.; BRUNSTEIN, J.; ST. AMANDA, J. B19 parvovirus: biochemical and molecular features. In: PARKS, W. P. (Ed.). Human parvovirus B19. New York: Karger, 1997. v. 20, p. 16-37.

AZZI, A.; MANARESI, E.; ZAKRZEWSKA, K.; DE SANTIS, R.; MUSIANI,M.; ZERBINI, M. Antibody response to B19 parvovirusVP1 and VP2 linear epitopes in patients with haemophilic arthritis. J. Med. Virol., v. 72, n. 4, p. 679-682, 2004.

BANSAL, G. P.; HATFIELD, J. A.; DUNN, F. E.; KRAMER, A. A.; BRADY, F.; RIGGIN, C. H.; COLlETT, M. S.; YOSHIMOTO, K.; KAJIGAYA, S.; YOUNG, N. S. Candidate recombinant vaccine for human parvovirus B19. J. Infect. Dis., v. 167, n. 5, p. 1034-1044, 1993.

BARAH, F.; VALLERY, P. J.; CHISWICK, M. L.; ClEATOR, G. M.; KERR, J. R. Association of human parvovirus B19 infection with acute meningoencephalitis. Lancet, v. 358, n. 9283, p. 727-730, 2001.

BEERSMA, M, F.; CLAAS, E. C.; SOPAHELUAKAN, T.; KROOES, A. C. Parvovirus B19 viral loads in relation to VP1 and VP2 antibody responses in diagnostic blood samples. $\mathbf{J}$. Clin. Virol.. v. 34, n. 1, p. 71-75, 2005.

BELL, L. M.; NAIDES, S. J.; STOFFMAN, P.; HODINKA, R. L.; PLOTKIN, S. A. Human parvovirus B19 infection among hospital staff members after contact with infected patients. N. Engl. J. Med., v. 321, n. 8, p. 485-491, 1989.

BERNS, K. I. Parvoviridae: The viruses and their replication. In: FIELDS, B. N.; KNIPE, D. M.; HOWLEY, P. M. (Ed.). Fundamental virology. 3. ed. Philadelphia: Raven, 1996. p. 1017-1041.

BERNS, K.; PARRISH, C. R. Parvoviridae. In: KNIPE, D. M.; HOWLEY, P. M. (Ed.). Fields virology. $5^{\text {th }}$. Philadelphia: Lippincott-Raven, 2007. v. 2, p. 2437-2466.

BERRY, P. J.; GRAY. E. S.; PORTER. H. J.; BURTON, P. A. Parvovirus infection of the human fetus and newborn. Semin. Diag. Pathol., v. 9, n. 1, p. 4-12, 1992.

BLUNDELL, M. C.; BEARD, C.; ASTELL, C. R. In vitro identification of a B19 parvovirus promoter. Virology, v. 157, n. 2, p. 534-538, 1987. 
BOCK, C. T.; KLINGEL, K.; ABERLE, S.; DUECHTING, A.; LUPESCU, A.; LANG, F.; KANDOLF, R. Human parvovirus B19: a new emerging pathogen of inflammatory cardiomyopathy. J. Vet. Med. B. Infect. Dis. Vet Public Health., v. 52, n.7-8, p. 340-343, 2005 .

BOGGINO, H.; PAYNE, D. A. Quantitative direct, probe method for the detection of parvovirus B19. J. Clin. Lab. Anal., v. 14, n. 1, p. 38-41, 2000.

BOUSQUET, F.; SEGONDY, M.; FAURE, J. M.; DESCHAMPS, F.; BOULOT, P. B19 parvovirus-induced fetal hydrops: good outcome after intrauterine blood transfusion at 18 weeks of gestation. Fetal Diagn. Ther., v. 15, n. 3, p. 132-133, 2000.

BROWN, C. S.; VAN LENT, J. W.; VLAK, J. M.; SPAAN, W. J. Assemblyof empty capsids by using baculovirus recombinants expressing human parvovirus B19 structural proteins. J. Virol., v. 65, n. 5, p. 2702-2706, 1991.

BROWN, K. E.; ANDERSON, S. M.; YOUNG, N. S. Erythocyte P antigen: cellular receptor for B19 parvovirus. Science, v. 262, n. 5130, p. 114-117, 1993.

BROWN, K. E.; BUCKLEY, M. M.; COHEN, B. J.; SAMUEL, D. An amplified ELISA for the detection of parvovirus B19 IgM using monoclonal antibody to FITC. J. Virol. Methods, v. 26, n. 2, p. 189-198, 1989.

BROWN, K. E.; GREEN, S. W.; ANTUNEZ DE MAYOLO, J.; BELLANTI, J. A.; SMITH, S. D.; SMITH, T. J.; YOUNG, N. S. Congenital anaemia after transplacental B19 parvovirus infection. Lancet, v. 343, n. 8902, p. 895-896, 1994.

BROWN, T.; ANAND, A.; RITCHIE, L. D.; CLEWLEY, J. P.; REID, T. M. Intrauterine parvovirus infection associate with hydropes fetalis. Lancet, v. 2, n. 8410, p. 1033-1034, 1984.

CANDOTTI, D.; DANSO, K.; PARSYAN, A.; DOMPREH, A.; ALLAIN, J. P. Maternalfetal transmission of human parvovirus B19 genotype 3. J. Infect. Dis., v. 194, n. 5, p. 608$611,2006$.

CARTTER, M. L.; FARLEY, T. A.; ROSENGREN, S.; QUINN, D. L.; GILLESPIE, S. M.; GARY, G. W.; HADLER, J. L. Occupatioanal risk factors for infection with parvovirus B19 among pregnant women. J. Infect. Dis., v. 163, n. 2, p. 282-285, 1991.

CASSINOTTI, P.; BAS, S.; SIEGL, G.; VISCHER, T. L. Association between human parvovirus B19 infection and arthritis. Ann. Rheum. Dis., v. 54, n. 6, p. 498-500, 1995.

CASSINOTTI, P.; SCHULTZE, D.; SCHLAGETER, P.; CHEVILI, S.; SIEGL, G. Persistent human parvovirus B19 infection following an acute infection with meningitis in an immunocompetent patient. Eur. J. Clin. Microbiol. Infect. Dis., v. 12, n. 9, p. 701-704, 1993.

CAUL, E. O.; USHER, M. J.; BURTON, P. A. Intrauterine infection with human parvovirus B19: a light and electron microscopy study. J. Med. Virol., v. 24, n. 1, p. 55-66, 1988. 
CENTERS FOR DISEASE CONTROL (CDC). Risks associated with human parvovirus B19 infection. MMWR. Morb Mortal Wkly Rep., v. 38, n. 6, p. 81-88, 93-97, 1989.

CHEVREL, G.; CALVET, A.; BELIN, V.; MIOSSEC, P. Dermatomyositis associated with the presence of parvovirus B19 DNA in muscle. Rheumatology, Oxford, v. 39, n. 9, p. 1037$1039,2000$.

CHIA, J. K.; JACKSON, B. Myopericarditis due to parvovirus B19 in an adult. Clin. Infect. Dis., v. 23, n. 1, p. 200-201, 1996.

CHISAKA, H.; ITO, K.; NIIKURA, H.; SUGAWARA, J.; TAKANO, T.; MURAKAMI, Y.; TERADA, Y.; OKAMORA, K.; SHIROISHI, H.; SUGAMURA, K.; YAEGASHI, N. Clinical manifestations and outcomes of parvovirus B19 infection during pregnancy in Japan. Tohoku J. Exp. Med., v. 209, n. 4, p. 277-283, 2006.

CHISAKA, H.; MORITA, E.; YAEGASHI, N.; SUGAMURA, K. Parvovirus B19 and the pathogenesis of anaemia. Rev. Med. Virol., v. 13, n. 6, p. 347-359, 2003.

CHORBA, T.; COCCIA, P.; HOLMAN, R. C.; TATTERSALL, P.; ANDERSON, L. J.; SUDMAN, J.; YOUNG, N. S.; KURCZYNSKI, E.; SAARINEN, U. M.; MOIR, R.. The role of parvovirus B19 in aplastic crisis and erythema infectiosum (fifth disease). J. Infect. Dis., v. 154, n. 3, p. 383-393, 1986.

CHRYSTIE, I. L.; ALMEIDA, J. D.; WELCH, J. Electron microscopic detection of human parvovirus B19 in a patient with HIV infection. J. Med. Virol., v. 30, n.4, p. 249-252, 1990.

CLEWLEY, J. P. Detection of human parvovirus using a molecularly cloned probe. J. Med. Virol., v. 15, n.2, p.173-181, 1985.

CLEWLEY, J. P. Polymerase chain reaction assay of parvovirus B19 in clinical species. J. Clin. Microbiol., v. 27, n. 12, p. 2647-2651, 1989.

COHEN, B. J.; BATES. C. M. Evaluation of 4 commercial test kits for parvovirus B19specific IgM. J. Virol. Methods, v. 55, n. 1, p. 11-25, 1995.

COHEN, B. J.; BEARD, S.; KNOWLES, W. A.; ELLIS, J. S.; JOSKE, D.; GOLDMAN, J. M.; HEWITT, T.; WARD, K. N. Chronic anemia due to parvovirus B19 infection in a bone marrow transplant patient after platelet transfusion. Transfusion, v. 37, n. 9, p. 947-952, 1997.

COHEN, B. J.; BROWN, K. E. Laboratory infection with human parvovirus B19. J. Infect., v. 24, n. 1, p. 113-114, 1992.

COHEN, B. J.; BUCKLEY, M. M. The prevalence of antibody to human parvovirus B19 in England and Wales. J. Med. Microbiol., v. 25, n. 2, p. 151-153, 1988.

COHEN, B. J.; GANDHI, J.; CLEWLEY, J. P. Genetic variants of parvovirus B19 identified in the United Kingdom: implications for diagnostic testing. J. Clin. Virol., v. 36, n. 2, p. 152$155,2006$. 
COHEN, B. J.; MORTIMER, P. P.; PEREIRA, M. S. Diagnostic assay with monoclonal antibodies for the human serum parvovir us-like virus (SPLV). J. Hyg., London, v. 91, n. 1, p. 113-130, 1983.

CORCORAN, A.; CROWLEY, B.; DEWHURST, C.; PIZER, B. L.; DOYLE, S. Establishment of functional B cell memory against parvovirus B19 capsid proteins may be associated with resolution of persistent infection. J. Med. Virol., v. 78, n. 1, p. 125-128, 2006.

CORMAN, L. C.; DOLSON, D. J. Polyarteritis nodosa and parvovirus B19 infection. Lancet, v. 339, n. 8791, p. 491, 1992.

COSSART, Y. E.; CANT, B.; FIELD, A. M.; WIDDOWS, D. Parvovirus-like particles in human serum. Lancet, v. 1, n. 7898, p. 72-73, 1975.

COTMORE, S. F.; McKIE, V. C.; ANDERSON, L. J.; ASTELL, C. R.; TATTERSALL, P. Identification of the major structural and nonstructural proteins encoded by human parvovirus B19 and mapping of their gene by prokaryotic expression of isolated genomic fragments. $\mathbf{J}$. Virol., v. 60, n. 2, p. 548-557, 1986.

COUROUCE, A. M.; FERCHAL, F.; MORINET, F.; MULlER, A.; DROUET, J.; SOULIER, J. P.; PEROL, Y. Human parvovirus infections in France. Lancet, v. 1, n. 8369, p. 160, 1984.

CRUZ, A. S.; SERPA, M. J. A.; BARTH, O. M.; NASCIMENTO, J. P. Detection of the human parvovirus B19 in a blood donor plasma in Rio de Janeiro. Mem. Inst. Oswaldo Cruz, v. 84, n. 2, p. 279-280, 1989.

CUBEL, R. C. N.; VAlADAO, M. C.; PEREIRA, W. V.; MAGAlHÃES, M. C.; NASCIMENTO, J. P. Aplastic crisis due to human parvovirus B19 infection in hereditary hemolytic anaemia. Rev. inst. Med. Trop. São Paulo, v. 34, n. 5, p. 479-482, 1992.

CUBEL, R. C.; ALFERES, A. C.; COHEN, B. J.; NASCIMENTO, J. P. Application to immunoglobulin $\mathrm{M}$ capture hemadherence assay of hemaglutination of monkey erytrocytes by inative and recombinant human parvovirus B19 antigen. J. Clin. Microbiol., v. 32, n. 8, p. 1997-1999, 1994.

CUBEL, R. C.; GARCIA, A. G.; PEGADO, C. S.; RAMOS, H. I.; FONSECA, M. E.; CLEWLEY, J. P.; COHEN, B. J.; NASCIMENTO, J. P. Human parvovirus B19 infection and hydrops fetalis in Rio de Janeiro, Brazil. Mem. Inst. Oswaldo Cruz, v. 91, n. 2, p. 147-151, 1996.

CUBEL, R. C.; SERQUEIRA, M. M.; SANTOS, E. O.; PIRES, M. F.; CRUZ, C. M.; NASCIMENTO, J. P. Human parvovirus B19 infection among exantematic diseases notifield as measles. Rev. Soc. Bras. Med. Trop., v. 30, n. 1, p. 15-20, 1996.

DEISS, V.; TRATSCHIN, J. D.; WEITZ, M.; SIEGL, G. Cloning of the human parvovirus B19 genome and structural analysis of its palindromic termini. Virology, v. 175, n. 1, p. 247254, 1990. 
DENNING, D. W.; AMOS, A.; RUDGE, P.; COHEN, B. J. Neuralgic amyotrophy due to parvovirus infection. J. Neurol. Neurosurg. Ps ychiatr., v. 50, n. 2, p. 641-642, 1987.

DIAZ, F.; COLLAZOS, J. Glomerulonephritis and Henoch-Schoenlein purpura associated with acute parvovirusB19 infection. Clin. Nephrol., v. 53, n. 3, p. 237-238, 2000.

DIAZ, F.; COLlAZOS, J.; MENDONZA, F.; DE LA VIUDA, J. M.; CAZALLAS, J.; URKIJO, J. C.; FLORES, M. Systemic lupus erythematosus associated with acute parvovirus B19 infaction. Clin. Microbiol. Infect., v. 8, n. 2, 115-117. 2002.

DOBEC, M.; JUCHLER, A.; FLAVIANO, A.; KAEPPELI, F. Prolonged parvovirus B19 viremia in spite of neutralizing antibodies after erythema infectiosum in pregnancy. Ginecol. Obstet. Invest., v. 63, n. 1, p. 53-54, 2007.

DOWELL, S. F.; TÖRÖK, T. J.; THORP, J. A.; HEDRICK, J.; ERDMAN, D. D.; ZAKI, S. R.; HINKLE, C. J.; BAYER, W. L.; ANDERSON, L. J. Parvovirus B19 infection in hospital workers: community or hospital acquisition? J. Infect. Dis., v. 172, n. 4, p. 1076-1079, 1995.

DOYLE, S.; KERR, S.; O’ KEEFER, G.; O’CARROLL, D.; DALY, P.; KITY,C. Detection of parvovirus B19 IgM by antibody capture enzyme immunoassay: receiver operating characteristic analysis. J. Virol. Methods, v. 90, n. 2, p. 143-152, 2000.

DRUMOND, A. J.; RAMBAUT, A. 2003. BEAST. Version 4.3 [computer program]. Disponível em: <http://evolve.zoo.ox.ac.uk/beast>. Acesso em: 20 ago. 2007.

DURIGON, E. L.; ERDMAN, D. D.; ANDERSON, B. C.; HOLLOWAY, B. P.; ANDERSON, L. J. Immunochemiluminescent Southern blot assay for polymerase chain reaction detection of human parvovirus B19 DNA. Mol. Cell. Probes, v. 8, n. 3, p. 199-203, 1994.

DURIGON, E. L.; ERDMAN, D. D.; GARY, G. W.; PALLANSCH, M. A.; TOROK, T. J.; ANDERSON, L. J. Multiple primer pairs for polymerase chain reaction (PCR) amplification of human parvovirus B19 DNA. J. Virol. Methods, v. 44, n. 2/3, p. 155-165, 1993.

ERDMAN, D. D.; DURIGON E. L.; HOLLOWAY, B. P. Detection of human parvovirus B19 DNA PCR products by RNA probe hybridization enzyme immunoassay. J. Clin. Microbiol., v. 32, n. 9, p. 2295-2298, 1994.

ERDMAN, D. D.; DURIGON E. L.; WANG, Q. Y.; ANDERSON L. J. Genetic diversity of human parvovirus B19: sequence analysis of the VP1/VP2 gene from multiple isolates. $\mathbf{J}$. Gen. Virol., v. 77, Pt. 11, p. 2767-2774, 1996.

ERDMAN, D. D.; USHER, M. J.; TSOU, C.; CAUL, E. O.; GARY, G. W.; KAJIGAYA, S.; YOUNG, N. S.; ANDERSON, L. J. Human parvovirus B19 specific IgG, IgA, and IgM antibodies and DNA in serum specimens from persons with erythema infectiosum. $\mathbf{J}$. Med.Virol., v. 35, n. 2, p. 110-115, 1991.

ERGAZ, Z.; ORNOY, A. parvovirus B19 in pregnancy. Reprod. Toxicol., v. 21, n. 4, p. 421435, 2006. 
EVANS, J. P.; ROSSITER, M. A.; KUMARAN, T. O.; MARSH, G. W.; MORTIMER, P. P. Human parvovirus aplasia: case due to cross infection in a ward. Br. Med. J., v. 288, n. 6418, p. 681, 1984.

FADEN, H.; GARY, G. W. Jr; KORMAN, M. Numbness and tinglind of fingers associated with parvovirus B19 infection. J. Infect. Dis., v. 161, n. 2, p. 354-355, 1990.

FARR, G. A.; TATTERSALL, P. A conserved leucine that constricts the pore through the capsids fivefold cylinder plays a central role in parvoviral infections. Virology, v. 323, n. 2, p. 243-256, 2004.

FIELD, A. M.; COHEN, B. J.; BROWN, K. E.; MORI, J.; CLEWLEY, J. P.; NASCIMENTO, J. P.; HALLAM, N. F. Detection of B19 parvovirus in human fetal tis sues by electron microscopy. J. Med. Virol., v.35, n. 2, p. 85-95, 1991.

FINKEL, T. H.; TÖROK, T. J.; FERGUSON, P. J.; DURIGON, E. L.; ZAKI, S. R.; LEUNG, D. Y.; HARBECK, R. J.; GELFAND, E. W.; SAULSBURY, F. T.; HOLLISTER, J. R. Chronic parvovirus B19 infection and systemic necrotising vasculitis: opportunistic infection or aetiological agent? Lancet, v. 344, n. 8908, p. 1255-1258, 1994.

FLUNKER, G.; PETERS, A.; WIERSBITZKY, S.; MODROW, S.; SEIDEL, W. Persistent parvovirus B19 infections in immunocompromised children. Med. Microbiol. Immunol., v. 186, n. 4, p. 189-194, 1998.

FOTO, F.; SAAG, K. G.; SCHAROSCH, L. L.; HOWARD, E. J.; NAIDES, S. J. Parvovirus B19-specific DNA in bone marrow from B19 arthropathy patients: evidence for B19 virus persistence. J. Infect. Dis., v. 167, n. 3, p. 744-748, 1993.

FREITAS, R. B.; DURIGON, E. L.; OLIVEIRA, D. S.; ROMANO, C. M.; DE FREITAS, M. R.; LINHARES, A. C.; MELO, F. L.; WALSHKELLER, L.; BARBOSA, M. L.; HUATUCO, E. M.; HOLMES, E. C.; ZANOTTO, P. M. The "pressure pan" evolution of human erythrovirus B19 in the Amazon, Brazil. Virology, v. 369, n. 2, p. 281-287, 2007

FREITAS, R. B.; GUSMÃO, S. R. B.; DURIGON, E. L.; LINHARES, A. C. Survey of parvovirus B19 infection in a cohort of pregnant women in Belém, Brazil. Braz J. Infect. Dis., v. 3, n. 1, p. 6-14, 1999.

FREITAS, R. B.; LINHARES, A. C.; MIRANDA, M. F. R.; GABBAY, Y. B. Novo agente de doença exantemática na Amazônia: O Parvovirus "B19". Bol. Epidemiol., Rio de Janeiro, v. 20, n. 1, p. 1-4, 1988.

FREITAS, R. B.; MIRANDA, M. F. R.; SHIRLEY, J.; TUDOR, R.; DESSELBERGER, U.; LINHARES, A. C. Parvovirus B19 antibodies in sera of patients with unexplained exanthema from Belém, Pará, Brazil. Mem. Inst. Oswaldo Cruz, v. 88, n. 3, p. 497-499, 1993.

FREITAS, R. B.; MONTEIRO, T. A. F.; SILVA FILHO, M. G.; LINHARES, A. C. Association between human parvovirus B19 and arthropathy in Belém, Pará, North Brazil. Rev. Inst. Med. Trop. São Paulo, v. 44, n. 1, p. 17-22, 2002. 
FREITAS, R. B.; WONG, D.; BOSWEL, F.; MIRANDA, M. F. R.; LINHARES, A. C.;SHIRLEY, J.; DESSELBERGER, U. Prevalence of Human Parvovirus (B19) and rubellavirus infections in urban and remote rural areas in Northern Brazil. J. Med. Virol., v. 32, n. 4, p. 203-208, 1990.

FRICKHOFEN, N.; ABKOWITZ, J. L.; SAFFORD, M; BERRY, J. M.; ANTUNEZ DE MAYOLO, J.; ASTROW, A.; COHEN, R.; HALPERIN, J.; KING, L.; MINTZER, D. Persistent B19 parvovirus infection in patients infected with human immunodeficiency virus type 1 (HIV -1): a treatable cause of anaemia in AIDS. Ann. Intern. Med., v. 113, n. 12, p. 926-933, 1990.

FRICKHOFEN, N.; ARNOLD, R.; HERTENSTEIN, B.; WIESNETH, M.; YOUNG, N. S. Parvovirus B19 infection and bone marrow transplantation. Ann. Hematol., v. 64, p. A121A124, 1992. Supplement A.

FRIDELL, E.; COHEN, B. J.; WAHREN, B. Evolution of a synthetic-peptide enzyme-linked immunosorbent assay for immunoglobulin $\mathrm{M}$ to human parvovirus B19. J. Clin. Microbiol., v. 29, n. 7, p. 1376-1381, 1991.

FRYER, J. F,.; KAPOOR, A.; MINOR, P. D.; DELWART, E.; BAYLIS, S. A. Novel parvovirus and related variant in human plasma. Emerg. Infec. Dis., v. 12, n. 1, p. 151-154, 2006.

GALLINELLA, G.; ANDERSON, S. M.; YOUNG, N.S.; BROWN, K.E. Human parvovirus B19 can infect cynomolgus monkey marrow cells in tissue culture. J. Virol., v. 69, n6, p. 3897-3899, 1995.

GALLINELlA, G.; VENTUROLI, S.; GENTILOMI, G.; MUSIANI, M.; ZERBINI, M. Extent of sequence variability in a genomic region coding for capsid proteins of B19 parvovirus. Arch. Virol., v. 140, n. 6, p. 1119-1125, 1995.

GALLINELLA, G.; VENTUROLI, S.; MANAREZE, E.; MUSIANI, M.; ZERBINI, N. B19 virus genome diversity: epidemiological and clinical correlations. J. Clin. Virol., v. 28, n. 1, p. 1-13, 2003.

GAREUS, R.; GINGLER，A.; HEMAUER，A.; LERUEZ-VILLE，M.; MORINET, F.; WOLF, H.; MODROW, S. Caracterizacion of cis-acting and NSI protein-responsive elements in the p6 promoter of parvovirus B19. J. Virol., v. 72, n. 1, p. 609-616, 1998.

GAY, N, J.; HESKETH, L. M.; COHEN, B. J.; RUSH, M.; BATES, C.; MORGANCAPNER, P.; MILLER, E. Age specific antibody prevalence to parvovirus B19: How many women are infected in pregnancy? Commun. Dis. Rep. CDR Rev., v. 4, n. 9, p. 104-107, 1994.

GILLESPIE, S. M.; CARTTER, M. L.; ASCH, S.; ROKOS, J. B.; GARY, G. W.; TSOU, C.; HALL, D. B.; ANDERSON, L. J.; HURWITZ, E. S. Occupational risk of human parvovirus B19 infection for school and day care personnel during an outbreak of arythema infectiosum. JAMA, v. 263, n. 15, p. 2061-2065, 1990. 
GRAEVE, J. L.; DE ALARCON, P. A.; NAIDES. S. J. Parvovirus B19 infection in patients receiving cancer chemotherapy: the expanding spectrum of disease. Am. J. Pediatr. Hematol. Oncol., v. 11, n. 4, p. 441-444, 1989.

GRUBER, F.; FALKNER, F. G.; DORNER, F.; HAMMERLE, T. Quantitation of viral DNA by realtime PCR applying duplex amplification, internal standardization and two-color fluorescence detection. Appl. Environ. Microbiol., v. 67, n. 6, p. 2837-2839, 2001.

HALL, T. A.: BioEdit: biological sequence alignment editor for Windows. North Carolina State University, NC, 1999. Disponível em:

<http://www.mbio.ncsu.edu/BioEdit/bioedit.html>. Acesso em: 20 ago. 2007.

HASLE, H.; HEEGAARD, E.; KERNDRUP, G.; JENSEN, I. M.; PETERSLUND, N. A.; HORNSLETH, A. Parvovirus B19 infection infrequently involved in children and adults with myelodysplastic syndrome. Leuk. Res., v. 20, n. 1, p. 81-83, 1996.

HAYAKAWA, F.; IMADA, K.; TOWATARI, M.; SAITO, H. Life-threatening human parvovirus B19 infection transmitted by intravenous immune globulin. Br. J. Haematol., v. 118, n. 4, p. 1187-1189, 2002.

HEEGAARD, E. D.; PANUM JANSEN, I.; CHRISTESEN, J. Novel PCR assay for differential detection and screening of erythrovirus B19 and erythrovirus V9. J. Med. Virol., v. 65 , n. 2, p. 362-367, 2001.

HEEGAARD, E. D.; EISKJAER, H.; BAANDRUP, U.; HORNSLETH, A. Parvovirus B19 infection associated with myocarditis following adult cardiac transplantation. Scand. J. Infect. Dis., v. 30, n. 6, p. 607-610, 1998.

HEEGAARD, E. D.; HORNSLETH, A. Parvovirus: the expanding spectrum of disease. Acta Paediatr. v. 84, n. 2, p. 109-117, 1995.

HEEGAARD, E. D.; PETERSEN, B. L.; HEILMANN, C. J.; HOMSLETH, A. Prevalence of parvovirus B19 and parvovirus V9 DNA and antibodies in paired bone marrow and serum from healthy individuals. J. Clin. Microbiol., v. 40, n. 3, p. 933-936, 2002.

HEEGAARD, E. D.; PETERSLUND, N. A.; HORNSLETH, A. Parvovirus B19 infection associated with encephalitis in a patient suffering from malignant lymphoma. Scand. J. Infect. Dis., v. 27, n. 6, p. 631-633, 1995.

HEMAUER, A.; Von POBLOTZKI, A.; GIGLER, A.; CASSINOTTI, P.; SIEGL, G.; WOLF, H.; MODROW, S. Sequence variability among different parvovirus B19 isolates. J. Gen.Virol., v. 77, Pt 8, p. 1781-1785, 1996.

HOEBE, C. J.; CLAAS, E. S.; VAN STEENBERGEN, J. E.; KROES, A. C. M. Confirmation of an outbreak of parvovirus B19 in a primary school using IgM ELISA and PCR on thumb prick blood samples. J. Clin. Virol., v. 25, n. 3, p. 303-307, 2002. 
HOKYNAR, K.; BRUNSTEIN, J.; SÖDERLUND-VENERMO, M.; KIVILUOTO, O.; PARTIO, E. K.; KONTTINEN, Y.; HEDMAN, K. Integrity and full coding sequence of B19 virus DNA persisting in human synovial tissue. J. Gen. Virol., v. 81, Pt 4, p. 1017-1025, 2000 .

HOKYNAR, K.; SÖDERLUND-VENERMO, M.; PESONEN, M.; RANKI, A.; KIVILUOTO, O.; PARTIO, E. K.; HEDMAN, K. A new parvovirus genotype persistent in human skin. Virology, v. 302, n. 2, 224-228, 2002.

HOLM, J.N.; HANSEN, L.K.; OXHOJ, H. Kawasaki disease associted with parvovirus B19 infection. Eur. J. Pediatr., v. 154, n. 8, p.633-634, 1995.

HSU, T. C.; TSAY, G. J. Human parvovirus B19 infection in patients with systems lúpus erythematosus. Rheumatology, Oxford, v. 40, n. 2, p. 152-157, 2001.

INOUE, S.; KINRA, N. K.; MUKKAMALA, S. R.; GORDON, R. Parvovirus B-19 infection: aplastic crisis, erythema infectiosum and idiopathic thrombocytopenic purpura. Pediatr. Infect. Dis. J., v.10, n. 3, p. 251-253, 1991.

ISA, A.; KASPROWICZ, V.; NORBECK, O.; LOUGHRX, A.; JEFFERY, K.; BROLIDEN, K.; KLENERMAN, P.; TOLIVENSTAM, T.; BOWNESS, P. Prolonged activation of virusespecific CD8+T cells after acute B19 infection. PloS Med., v. 2, n. 12, p. e343, 2005.

ISA, A.; NORBECK, O.; HIRBOD, T.; LUNDQVIST, A.; KASPROWICZ, V.; BOWNESS, P.; KLENERMAN, P.; BROLIDEN, K.; TOLFVENSTAM, T. Aberrant cellular immune response in humans infected persistently with parvovirus B19. J. Med. Virol., v. 78, n. 1, p. 129-133, 2006.

JANNER, D.; BORK, J.; BAUM, M.; CHINNOCK, R. Severe pneumonia after heart transplantation as a result of human parvovirus B19. J. Heart Lung Transplant., v.13, n. 2, p. 336-338, 1994.

JOSEPH, P. R. Fifth disease: the frequency of joint involvement in adults. N. Y. State J. Med., v. 86, n. 11, p. 560-563, 1986.

KAJIGAYA, S.; FUJII, H.; FIELD, A.; ANDERSON, S.; ROSENFELD, S.; ANDERSON, L. J.; SHIMADA, T.; YOUNG, N. S. Self-assembled B19 parvovirus capsids, produced in a baculovirus system, are antigenically and immunogelically similar to native virions. Proc. Natl. Acad. Sci., USA, v. 88, n. 11, p. 4646-4650, 1991.

KAJIGAYA, S.; SHIMADA, T.; FUJITA, S.; YOUNG, N. S. A genetically angineered cell line that produces empty capsids of B19 (human) parvovirus. Proc. Natl. Acad. Sci. USA, v. 86, n. 19, p. 7601-7605, 1989.

KAPLAN, C.; MORINET, F.; CARTRON, J. Virus-induced autoimmune thrombocytopenia and neutropenia. Semin. Hematol., v. 29, n. 1, p. 34-44, 1992.

KELLEHER, J. F.; LUBAN, N. L.; MORTIMER, P. P.; KAMIMURA, T. Human serum parvovirus: a specific cause of aplastic crisis in children with hereditary spherocytosis. $\mathbf{J}$. Pediat., v. 102, n. 5, p. 720-722, 1983. 
KELLERMAYER, R.; FADEN, H.; GROSSI, M. Clinical presentation of parvovirus B19 infection in children with aplastic crisis. Pediatr. Infect. Dis. J., v. 22, n.12, p. 1100-1101, 2003.

KERR, J. R.; COYLE, P. V.; DE LEYS, R. J.; PATTERSON, C. C. Follow-up study of clinical and immunological findings in patients presenting with acute parvovirus B19 infection. J. Med. Virol., v. 48, n. 1, p. 68-75, 1996.

KERR, J. R.; CURRAN, M. D.; MOORE, J. E.; MURPHY, P. G. Parvovirus B19 infectionpersistence and genetic variation. Scand. J. Infect. Dis., v. 27, n. 6, p. 551-557, 1995.

KNOTT, P. D.; WELPLY, G. A. C.; ANDERSON, M. J. Serologically proved intrauterine infection with parvovirus. Br. Med. J., v. 289, n. 6459, p. 1660, 1984.

KOCH, W. C.; ADLER, S. P.; HARGER, J. Intrauterine parvovirus B19 infection may cause an asymptomatic or recurrent postnatal infection. Pediat. Infect. Dis. J., v. 12, n. 9, p. 747$750,1993$.

KOCH, W. C.; MASSEY, G.; RUSSEL. C. E.; ADLER. S. P. Manifestations and treatment of human parvovirus B19 infection in immunocompromised patients. J. Pediatr., v. 116, n. 3 p. 355-359, 1990.

KODURI, P. R. Novel cytomorphology of the giant proerythroblasts of parvovirus B19 infection. Am. J. Hematol., v. 58, n. 2, p. 95-99, 1998.

KODURI, P. R. Parvovirus B19-related anemia in HIV-infected patients. AIDS Patients Care STDS, v. 14, n.1, p. 7-11, 2000.

KOJIMA, S.; MATSUYAMA, K.; ISHII,E. High serum iron in human parvovirus induced aplastic crisis in iron deficiency anemia. Acta Haematol., v. 80, n. 3, p. 171-172, 1988.

KUMAR, S.; TAMURA, A.; NEI, M. MEGA 3: integrated software for molecular evolutionary genetic analysis and sequence alignment. Brief. Bioinform., v. 5, p. 150-160, 2004.

KURTZMAN, G. J.; COHEN, B. J.; FIELD, A. M..; OSEAS, R.; BLAESE, R. M.; YOUNG, N. S. Immune response to B19 parvovirus and an antibody defect in persistent viral infection. J. Clin. Invest., v. 84, n. 4, p. 1114-23, 1989b.

KURTZMAN, G. J.; COHEN, B.; MEYERS, P.; AMUNULlAH, A.; YOUNG, N. S. Persistent B19 parvovirus infection as a cause of severe chronic anaemia in children with acute lymphocytic leukaemia. Lancet, v. 2, n. 8621, p. 1159-1162, 1988.

KURTZMAN, G. J.; FRICKHOFEN, N.; KIMBALL, J.; JENKINS, D. W.; NIENHUIS, A. W,. YOUNG, N, S. Pure red-cell aplasia of 10 years' duration due to persistent parvovirus B19 infection and its cure with immunoglobulin therapy. N. Eng. J. Med., v. 321, n. 8, p. 519-23, 1989a. 
KURTZMAN, G. J.; OZAWA, K.; COHEN, B.; HANSON, G.; OSEAS, R.; YOUNG, N. S. Chronic bone marrow failure due to persistent B19 parvovirus infection. N. Engl. J. Med., v. 317, n. 5, p. 287-294, 1987.

LEE, P. C.; HUNG, C. J.; LIN, Y. J.; WANG, J. R.; JAN, M. S.; LEI, H. Y. A role for chronic parvovirus B19 infection in live dysfunction in renal transplants? Transplantation, v. 73, n. 10, p. 1635-1639, 2002.

LENNERZ, C.; MADRY, H.; EHLHARDT, S.; VENZKE, T.; ZANG, K. D.; MEHRAEIN, Y. Parvovirus B19-related chronic monoarthritis: immunohistochemical detection of viruspositive lymphocytes within the synovial tissue compartment: two reported cases. Clin. Rheumatol., v. 23, n. 1, p. 59-62, 2003.

LI, W. H.; WU C. I.; LUO, C. C. A new method for estimating synonymous and nonsynonymous rates of nucleotide substitution considering the relative likelihood of nucleotide and codon changes. Mol. Biol. Evol., v. 2, p. 150-174, 1985.

LINHARES, A. C.; MIRANDA, M. F. R.; FREITAS, R. B. Parvovirus B19, eritema infeccioso e outras manifestações clínicas. An. Bras. Dermatol., v. 66, n. 6, p. 281-287, 1991.

LISBOA, C. P. Detecção do parvovirus B19 em doadores de sangue utilizando a técnica da reação da polimerase em cadeia (PCR). 109f. Tese (Mestrado em Microbiologia) Instituto de Ciências Biomédicas, Universidade de São Paulo, São Paulo, 1997.

LUO, W.; ASTELL, C. R. A novel protein encoded by small RNAs of parvovirus B19. Virology, v. 195, n. 2, p. 448-55, 1993.

LUZZI, G. A.; KURTZ, J. B.; CHAPEL, H. Humam parvovirus arthropathy and rheumatoid factor. Lancet, v. 1, n. 8439, p. 1218, 1985.

MADDISON, D. R.; MADDISON, W. P. McCLADE 4: analysis of phylogeny and character evolution. Version 4.08. Surdeland, USA: Sinauer Associates, 2001.

MAGRO, C. M.; ALLEN, J.; POPE-HARMAN, A.; WALDMAN, W. J.; MOH, P.; ROTHRAUFF, S.; ROSS, P. Jr. The role of microvascular injury in the evolution of idiopathic pulmonary fibrosis. Am. J. Clin. Pathol., v. 119, n. 4, p. 556-567, 2003.

MAGRO, C. M.; DAWOOD, M. R.; CROWSON, A. N. The cutaneous manifestations of human parvovirus B19 infection. Hum. Pathol., v. 31, n. 4, p. 488-497, 2000.

MARCHAND, S.; TCHERNIA, G.; HIESSE, C.; TERTIAN, G.; CARTRON, J.; KRIAA, F.; BOUBENIDER, S.; GOUPY, C, LECOINTE, D.; CHAPENTIER, B. Human parvovirus B19 infection in organ transplant recipients. Clin. Transplant., v. 13, Pt 1, p. 17-24, 1999.

MARTINEZ-MARTINEZ, P.; MARANON, A. Infection by human parvovirus B19: "Gloves and socks" popular purpuric syndrome. Diagn. Microbiol. Infect. Dis., v. 36, n.3, p. 209-310, 2000 . 
McOMISH, F.; YAP, P. L; JORDAN, A.; HART, H.; COHEN, B. J.; SIMMONDS, P. Detection of parvovirus B19 in donated blood: a model system for screening by polymerase chair reaction. J. Clin. Microbiol., v. 31, n. 2, p. 323-28, 1993.

MIRANDA, M. F. R.; LINHARES, A. C.; SHIRLEY, J. A. Fifth disease in children living in Belém, Brasil. Rev. Inst. Med. Trop., S. Paulo, v. 31, n. 5, p. 359-362, 1989.

MIYAGAWA, E.; YOSHIDA, T.; TAKAHASHI, H.; YAMAGUCHI, K.; NAGANO, T.; KIRIYAMA, Y.; OKOCHI, K.; SATO, H. Infection of the erythroid cell line, KU812Ep6 with human parvovirus B19 and its application to titration of B19 infectivity. J. Virol. Methods, v. 83, n. 1-2, p. 45-54, 1999.

MOFFATT, S.; YAEGASHI, N.; TADA, K.; TANAKA, N.; SUGAMURA, K. Human parvovirus B19 nonstructural (NS1) protein induces apoptosis in erythroid lineage cell. $\mathbf{J}$. Virol., v. 72, n. 4, p. 3018-3028, 1998.

MOREY, A. L.; FERGUSON, D. J.; LESLE, K. O.; TAATJES, D. J.; FLEMING, K. A. Intracellular localization of parvovirus B19 nucleic acid at the ultrastructural level by in situ hybridization with digoxigenin-labelled probes. Histochem. J., v. 25, n. 6, p. 421-429, 1993.

MOREY, A. L.; KEELING, J. W.; PORTER, H. J.; FlEMING, K. A. Clinical and histopatological features of parvovirus B19 infection in the human fetus. Br. J. Obstet. Gynaecol., v. 99, n. 7, p. 566-574, 1992.

MOREY, A. L.; NICOLINI, U.; WELCH, C. R; ECONOMIDES, D.; CHAMBERLAIN, P. F.; COHEN, B. J. Parvovirus B19 infection and transient fetal hydrops. Lancet, v. 337, p. 496, n. 8739, 1991.

MORI, J.; BEATTIE, P.; MELTON, D.W.; COHEN, B. J.; CLEWLEY, J. P. Struc ture and mapping of the DNA of human parvovirus B19. J. Gen. Virol., v. 68, Pt 11, p. 2797-2806, 1987.

MORINET, F.; COUROUCE, A. M.; GALIBERT, F.; PEROL, Y. The use of labeled fusion protein for detection of B19 parvovirus IgM antibodies by an immunocapture test. J. Virol. Methods, v. 32, n. 1, p. 21-30, 1991.

MORTIMER, P. P.; COHEN, B. J.; BUCKLEY, M. M.; CRADOCK-WATSON, J. E.; RIDEHALGH, M. K.; BURKHARDT, F.; SCHILT, U. Human parvovirus and the fetuses. Lancet, v. 2, n. 8462, p. 1012, 1985.

MORTIMER, P. P.; HUMPHRIES, R. K.; MOORE, J.G.; PURCELL, R. H.; YOUNG, N. S. A human parvovirus-like virus inhibits hematopoietic colony formation in vitro. Nature, $v$. 302, n. 5907, p. 426-429, 1983.

MUNAKATA, Y.; KATO, I.; SAITO, T.; KODERA, T.; ISHII, K. K.; SAZAKI, T. Human parvovirus B19 infection of monocytic cell line U937 and antibody-dependent enhancement. Virology, v. 345, n. 1, p. 251-257, 2006. 
MUNRO, K.; CROXSON, M. C.; THOMAS, S.; WILSON, N. J. Three cases of myocarditis in childhood associated with human parvovirus (B19 virus). Pedatr. Cardiol., v. 24, n. 5, p. 473-475, 2003.

MUNSHI, N. C.; ZHOU, S.; WOODY, M. J.; MORGAN, D.A.; SRIVASTAVA, A. Successful replication of parvovirus B19 in the human megakaryocytic leukemia cell line MB O2. J. Virol., v. 67, n. 1, p. 562-566, 1993.

MURRAY, J. C.; KELlEY. P. K.; HOGREFE, W. R.; McClAIN, K. L. Childhood idiopathic thrombocytopenic purpura: association with human parvovirus B19 infection. Am. J. Pediatr. Hematol. Oncol., v. 16, n. 4, p. 314-319, 1994.

NAIDES, S. J. Infection with parvovirus B19. Curr. Infect. Dis. Rep., v. 1, n. 3, p. 273-278, 1999.

NAKAZAWA, T.; TOMOSUGI, N.; SAKAMOTO, K.; ASAKA, M.; YURI, T.; ISHIKAWA, I.; KITAGWA, S. Acute glomerulonephritis after human parvovirus B19 infection. Am. J. Kidney Dis., v. 35, n. 6, p. E31, 2000.

NASCIMENTO, J. P.; BUCKLEY, M.; BROWN, K.; COHEN, B. J. The prevalence of antibody to human parvovirus B19 in Rio de Janeiro, Brazil. Rev. Inst. Med. Trop. São Paulo, v. 32, n.1, p. 41-45, 1990.

NASCIMENTO, J. P.; HALLAM, N. F.; MORI, J.; FIELD, A. M.; CLEWLEY, J. P.; BROWN, K. E.; COHEN, B. J. Detection of B19 parvovirus in human fetal tissues by in situ hybridization. J. Med. Virol., v. 33, n. 2, p. 77-82, 1991.

NASCIMENTO, J. P.; MISTCHENKO, A.; COHEN, B. J. Laboratory diagnosis of acute human parvovirus B19 infection by specific IgM detection. Rev. Inst. Med. Trop. São Paulo, v. 40, n. 4, p. 265-266, 1998.

NGUYEN, Q. T.; SIFER, C.; SCHNEIDER, V.; ALLAUME, X.; SERVANT, A.; BERNALDIN, F.; AUGUSTE, V.; GARBARG-CHENON, A. Novel human erythrovirus associated with transient aplastic anemia. J. Clin, Microbiol., v. 37, n. 8, p. 2483-2487, 1999.

NGUYEN, Q. T.; WONG, S.; HEEGAARD, E. D.; BROWN, K. E. Identification and characterization of a second novel human erythrovirus variant, A6. Virology, v. 301, n. 2, p. 374-380, 2002.

NIGRO, G.; D'EUFEMIA, P.; ZERBINI, M.; KRZYSZTOFIAK, A.; FINOCCHIARO, R.; GIARDINI, O. Parvovirus B19 infection in a hypogammaglobolinemin infant with neurologic disorders and anemia: successful immunoglobulin therapy. Pediatr. Infect. Dis. J., v. 13, n. 11, p. 1019-1021, 1994.

NIITSU, H.; TKATSU, H.; MIURA, I.; CHUBACHI, A.; ITO, T.; HIROKAWA, M.; ENDO, Y.; MIURA, A.; FUKUDA, M.; SASAKI, T. Pure red cell aplasia induced by B19 parvovirus during allogeneic bone marrow transplantation. Rinsho ketsueki, v. 31, n. 9, p. 1566-1571, 1990. 
NIKKARI, S.; LAPPALAINEN, H.; SAARIO, R.; LAMMINTAUSTA, K.; KOTILAINEN, P. Detection of parvovirus b19 in sky biopsy, serum, and bone marrow of a patient with fever, rash, and polyarthritis followed by pneumonia, pericardial effusion, and hepatitis. Eur. J. Clin. Microbiol. Infect. Dis., v. 15, n. 12, p. 954-957, 1996.

NOCTON, J. J.; MILLER, L. C.; TUCKER, L. B.; SCHALLER, J. G. Human parvovirus B19-associated arthritis in children. J. Pediatr., v. 122, n. 2, p. 186-190, 1993.

NOLAN, R. C.; CHIDLOW, G.; FRENCH, M. A. Parvovirus B19 encephalitis presenting as immune restoration disease after highly active antiretroviral therapy for human immunodeficiency virus infection. Clin. Infect. Dis., v. 36, n. 9, p. 1191-1194, 2003.

NONOUE, T.; OKOCHI, K.; MORTIMER, P. P.; COHEN, B. J. Human parvovirus (B19) and erythema infectiosum. J. Pediatr., v. 107, n. 1, p. 38-40, 1985.

NYMAN, M.; TOLFVENSTAM, T.; PETERSSON, K.; KRASSNY, C.; SKJÖLDEBRANDSPARRE, L.; BROLIDEN, K. Detection of human parvovirus B19 infection in first-trimester fetal loss. Obstet. Gynecol., v. 99, n. 5, Pt. 1, p. 795-798, 2002.

O'MALLEY, A.; BARRY-KINSELLA, C, HUGHES, C.; KELEHAN, P.; DEVANEY, D.; MOONEY, E.; GILLAN, J. Parvovirus infects cardiac myocytes in hidrops fetalis. Pediatr. Dev. Pathol., v. 6, n. 5, p. 414-420, 2003.

OKUMURA, A.; ICHIKAWA, T. Aseptic meningitis caused by human parvovirus B19. Arch. Dis. Child., v. 68, n. 6, p. 784-785, 1993.

OLIVEIRA, A. S.; CAMACHO, L. A.; BETTINI, L. R.; FERNANDES, D. G.; GOUVEA, N. A.; BARROS, R. A.; SETUBAL, S.; SIQUEIRA, M. M. The joint manifestations of exanthematous viroses. Rev. Soc. Bras. Med. Trop., v. 32, n. 2, p. 125-130, 1999.

OLIVEIRA, A. S.; BRANDÃO, A. B.; FERNAMDES, D. G.; BETTINI, L. R.; CARVALHO, A. B.; PEREIRA, A. C.; AZEVEDO K. M.; NASCIMENTO, J. P. Human parvovirus B19 infection: clinical andepidemiological study of 24 cases. Rev. Int. Med. Trop. São Paulo., v. 38, n.5, p. 323-327, 1996.

OZAWA, K.; AYUB, J.; HAO, Y. S.; KURTZMAN, G.; SHIMADA, T.; YOUNG, N. Novel transcription map for the B19 (human) pathogenic parvovirus. J. Virol., v. 61, n. 8, p. 23952406, 1987.

OZAWA, K.; AYUB, J.; KAJIGAYA, S.; SHIMADA, T.; YOUNG, N. The gene encoding the nonstructural protein of B19 (human) parvovirus may be lethal in transfected cells. J. Virol., v. 62, n. 8, p. 2884-2889, 1988.

OZAWA, K.; KURTZMAN, G.; YOUNG, N. Replication of the B19 parvovirusin human bone morrow cell cultures. Science, v. 233, n. 4766, p. 883-886, 1986.

ÖZÇAY, F.; BIKMAZ, Y. E.; CANAN, O.; ÖZBEK, N. Hepatitis A and parvovirus B19 infections in an infant with fulminant hepatic failure. Turk. J. Gastroenterol., v. 17, n. 2, p. 148-150, 2006. 
PARSYAN, A.; SZMARAGD, C.; ALLAIN, J. P.; CANDOTTI, D. Identification and genetic diversity of two human parvovirus B19 genotype 3 subtypes. J. Gen. Virol., v. 88, Pt 2, p. 428-431, 2007.

PASSONI, L. F.; RIBEIRO, S. R.; GIORDANI, M. L.; MENEZES, J. A.; NASCIMENTO, J. P. Papular-purpuric "gloves and socks" syndrome due to parvovirus B19: report of a case with unusual features. Rev. Inst. Med. Trop. São Paulo, v. 43, n. 3, p. 167-170, 2001.

PATTISON, J. R.; JONES, S. E.; HODGSON, J.; DAVIS, L. R.; WHITE, J. M.; STROUD, C. E.; MURTAZA, L. Parvovirus infections and hypoplastic crisis sickle-cell anaemia. Lancet, v. 1, n. 8221, p. 664-665, 1981.

PEREIRA, A. C.; BARROS, R. A.; NASCIMENTO, J. P.; OLIVEIRA, S. A. Two family members with a syndrome of headache and rash caused by human parvovirus b19. Braz. J. Infect. Dis., v. 5, n.1, p. 37-39, 2001.

PILAVDZIC, D.; LINES, L. D.; PETRIC, M.; SILVER, M. M. Immunoelectron microscope identification of human parvovirus B19. Ultrastruct. Pathol., v. 18. n. 4, p. 417-422, 1994.

PILlAY, D.; PATOU, G.; HURT, S.; KIBBLER, C. C.; GRIFFITHS, P. D. Parvovirus B19 outbreak in a children's ward. Lancet, v. 339, n. 8785, p. 107-109, 1992.

PINHO, J. R.; ALVES, V. A.; VIEIRA, A. F.; MORALEZ, M. O.; FONSECA, L. E.; GUS, B.; WAKAMATSU, A.; CANÇADO, E. L.; CARRILHO, F. J.; DA SILVA, L. C.; BERNARDINI, A. P.; DURIGON, E. L. Detection of human parvovirus B19 in a patient with hepatitis. Braz. J. Med. Biol. Res., v. 34, n. 9, p. 1131-8, 2001.

POND, S. L.; FROST, S. D.; MUSE, S. V. Hyphy: hypothesis testing using phylogenies. Bioinformatics, v. 21, n. 5, p. 676-679, 2005.

POOLE, B. D.; KARETNYI, Y. V.; NAIDES, S. J. Parvovirus B19-induced apoptosis of hepatocytes. J. Virol., v. 78, n. 14, p. 7775-7783, 2004.

POSADA, D.; CRANDALL, K. A. MODELTEST: Testing the model of DNA substitution. Bioinformatics, v. 14, n. 9, p. 817-818, 1998.

PRINGLE, C. R. Virus taxonomy update. The International Committee on Taxonomy of Viruses. Arch. Virol., v. 133, n. 3-4, p. 491-495, 1993.

RAMAGE, J. K.; HALE, A.; GANE, E.; COHEN, B.; BOYLE, M.; MUFTI, G.; WILLIAMS, R. Parvovirus B19- induced red cell aplasia treated with plasmapheresis and immunoglobulin. Lancet, v. 343, n. 8898, p. 667-668, 1994.

RAMBAUT, A. Se-A1: Sequence aligment editor. 1996. Disponível em: <http://evolve.zoo.ox.ac. uk/>. Acesso em: 24 abr. 2007.

RAY, N. B.; NIEVA, D. R.; SEFTOR, E. A.; KHALKHALI-ELLIS, Z.; NAIDES, S. J. Induction of an invasive phenotype by human parvovirus B19 in normal human synovial fibroblasts. Arthritis Rheum., v. 44, n. 7, p. 1582-1586, 2001. 
REDDY, U. M.; BASCHAT, A. A.; ZLATNIK, M. G.; TOWBIN, J. A.; HARMAN, C. R.; WEINER, C. P. Detection of viral deoxyribonucleic acid in a amniotic fluid: association with fetal malformation and pregnancy abnormalities. Fetal Diagn. Ther., v. 20, n. 3, p. 203-207, 2005.

REID, D. M.; REID, T. M.; BROWN, T.; RENNIE, J. A.; EASTMOND, C. J. Human parvovirus associated arthritis: a clinical and laboratory description. Lancet, v. 1, n. 8426, p. 422-425, 1985.

RODERIC, D. M. 2000. TreeView. Version 3.1 (computer program). Disponível em: http://taxonomy.zoology.gla.ac.uk/rod/rod.html. Acesso em: 20 ago 2007.

ROSENFELD, S. J.; YOSHIMOTO, K.; KAJIGAYA, S.; ANDERSON, S.; YOUNG, N. S.; FIELD, A.; WARRENER, P.; BANSAL, G.; COLLETT, M. S. Unique region of the minor capsid protein of human parvovirus B19 is exposed on the virion surface. J. Clin. Invest., v. 89, n. 6, p. 2023-2029, 1992.

ROSENFELD, S. J.; YOUNG, N. S.; ALlinG, D.; AYUB, J.; SAXINGER, C. Subunit interaction in B19 parvovirus empty capsids. Arch. Virol., v. 136, n. 1/2, p. 9-18, 1994.

SAMBROOK, J.; FRITSCH, E.F.; MANIATIS, T. Molecular cloning : a laboratory manual. 2. ed. New York: CSHL Press, 1989.

SANABANI, S.; NETO, W. K.;. PEREIRA, J.; SABINO, E. C. Sequence Variability of Human Erythroviruses Present in Bone Marrow of Brazilian Patients with Various Parvovirus B19-Related Hematological Symptoms. J. Clin. Microbiol., v. 44, n. 2, p. 604-606, 2006.

SANT'ANNA, A. L.; GARCIA, R. C.; MARZOCHE, M.; DA ROCHA, H. H..; PAULA, M. T.; LOBO. C. C.; NASCIMENTO, J. P. Study of chronic hemolytic anaemia patients in Rio de Janeiro: prevalence of anti-human parvovirus B19 IgG antibodies and the development aplastic crises. Rev. Inst. Med. Trop. São Paulo, v. 44, n. 4, p. 187-190, 2002.

SCHEURLEN, W.; RAMASUBBU, K.; WACHOWSKI, O.; HEMAUER, A.; MODROW, S. Chronic autoimmune thrombopenia/neutropenia in a boy with persistent parvovirus B19 infection. J. Clin. Virol., v. 20, n. 3, p. 173-178, 2001.

SCHILD, R. L.; BALD, R.; PLATH, H.; EIS-HUBINGER, A. M.; ENDRS, G.; HANSMANN, M. Intrauterine management of fetal parvovirus B19 infection. Ultrasound. Obstet. Gynecol., v. 13, n. 3, p. 161-166, 1999.

SCHLEUNING, M.; JAGER, G.; HOLLER, E.; HILL, W.; THONSSEN, C.; DENZLINGER, C.; LORENZ, T.; LEDDEROSE, G.; WILMANNS, W.; KOLB, H. J. "Human Parvovirus B19-Associated Disease in Bone Marrow Transplantation". Infection, v. 27, n. 2, p. 114-117, 1999.

SCHMIDT, I.; BLÜMEL, J.; SEITZ, H.; WILLKOMMEN, H.; LÖWER, J. Parvovirus B19 DNA in plasma pools and plasma derivatives. Vox Sang., v. 81, n. 4, p. 228-235, 2001. 
SCHNEIDER, B.; HÖNE, A.; TOLBA, R. H.; FISCHER, H. P.; BLÜMEL, J.; EISHÜBINGER, A M. Simultaneous persistence of multiple genome variants of human parvovirus B19. J. Gen. Virol., v. 89, pt. 1, p. 164-176, 2008.

SERJEANT, G. R.; MASON, K.; TOPLEY, J. M.; SERJEANT, B. E.; PATTISON, J. L.; JONES, S.E.; MOHAMED, R. Outbreak of aplastic crises in sickle cell anaemiaassociated with parvovirus-like agent. Lancet, v. 2, n. 8247, p. 595-597, 1981.

SERKE, S.; SCHWARZ, T. F.; BAURMANN, H.; KIRSCH, A.; HOTTENTRÄGER, B.; VON BRUNN, A.; ROGGENDORF, M.; HUHN, D.; DEINHARDT, F. Productive infection of in vitro generated haemopoietic progenitor cell from normal human adults peripheral blood with parvovirus B19: studies by morphology, immunocytochemistry, flow cytometry and DNA-hibridization. Br. J. Haematol., v. 79, n. 1, p. 6-13, 1991.

SERVANT, A.; LAPERCHE, S.; LALLEMAND, F.; MARINHO, V.; DE SANT MAUR, G.; MERITET, J. F.; GARBARG-CHENON, A. Genetic diversity within human erythroviruses: identification of three genotypes. J. Virol., v. 76, n. 18, p. 9124-9134, 2002.

SETUBAL, S.; CARDIAS, C. A.; DE OLIVEIRA, S. A.; DO NASCIMENTO J. P. Viremic blood donor found by a rapid screening method in a season of high human parvovirus B19 activity in Niteroi, Rio de Janeiro, Brazil. Mem. Inst. Osvaldo Cruz, v. 99, n. 1, p. 95-99, 2004.

SETUBAL, S.; GABRIEL, A. H.; NASCIMENTO, J. P.; OLIVEIRA, S. A. Aplastic crisis caused By parvovirus B19 in an adult patient with sickle-cell disease. Rev. Soc. Bras. Med. Trop., v. 33, n. 5, p. 477-481, 2000.

SETUBAL, S.; JOEGE-PEREIRA, M. C.; DE SANT'ANNA, A. L. M.; DE OLIVEIRA, S. A.; BAZIN, A. R.; DO NASCIMENTO, J.P. Clinical presentation of parvovirus B19 infection in HIV-infected patients with and without AIDS. Rev. Soc. Bras. Med. Trop., v. 36, n. 2, p. 299-302, 2003.

SHACKLETON, L. A.; HOLMES, E C. Phylogenetic evidence for the rapid evolution of human B19 erythrovirus. J. Virol., v. 80, n.7, p. 3666-3669, 2006.

SHADE, R. O.; BLUNDELL, M. C.; COTMORE, S. F.; TATTERSAL, P.; ASTELL, C. R. Nucleotide sequence and genome organization of human parvovirus B19 isolated from the serum of a child during aplastic crisis. J. Virol., v. 58, n. 3, p. 921- 936, 1986.

SHIMOMURA, S.; KOMATSU, N.; FRICKHOFEN, N.; ANDERSON, S.; KAJIGAYA, S.; YOUNG, N. S. First continuous propagation of B19 parvovirus in a cell line. Blood, v. 79, n. 1, p. 18-24, 1992.

SHNEERSON, J. M.; MORTIMER, P. P.; VENDERVELDE, E. M.. Febrile illness due to a parvovirus. Br. Med. J., v. 280, n. 6231, p. 1580, 1980.

SIEGL, G.; BATES, R. B.; BERNS, K. I.; CARTER, B. J.; KELLY, D. C.; KURSTAK, E.; TATTERSALL, P. Characteristics and taxonomy of Parvoviridae. Intervirology, v. 23, n. 2, p. 61-73, 1985. 
SINHA, N. D.; BIERNAT, J.; McMANUS, J.; KÖSTER, H. Polymer support oligonucleotide synthesis XVIII: use of beta-cyanoethyl-N, N-dialkylamino-/ N-morpholino phosphoramidite of deoxynucleosides for the synthesis of DNA fragments simplifying deprotection and isolation of the final product. Nucl. Acid. Res., v. 12, n. 11, p. 4539-57, 1984.

SMITH, M. A.; SHAH, N. R.; LOBEL, J. S.; CERA, P. J.; GARI, G. W.; ANDERSON, L. J. Severe anaemia caused by human parvovirus in a leukemia patient on maintenance chemotherapy. Clin. Pediatr., Phila, v. 27, n. 8, p. 383-386, 1988.

SOKAL, E. M.; MELCHIOR, M.; CORNU, C.; VANDENBROUCKE, A. T.; BUTS, J. P.; COHEN, B. J.; BURTONBOY, G. Acute parvovirus B19 infection associated with fulminant hepatitis of favorable prognosis in young children. Lancet, v. 352, n. 9142, p. 1739-1741, 1998.

SRIVASTAVA, A.; BRUNO, E.; BRIDDELL, R.; COOPER, R.; SRIVASTAVA, C.; VAN BESIEN, K.; HOFFMAN, R. Parvovirus B19-induced perturbation of human megakaryocytopoiesis in vitro. Blood, v. 76, n. 10, p. 1997-2004, 1990.

SRIVASTAVA, C. H.; ZHOU, S.; MUNSHI, N. C.; SRIVASTAVA, A. Parvovirus B19 replication in human umbilical Cord blood cells. Virology, v. 189, n. 2, p. 456-461, 1992.

ST AMAND, J.; ASTELL, C. R. Identification and characterization of a family of $11 \mathrm{kDa}$ proteins encoded by the human parvovirus B19. Virology, v. 192, n. 1, p. 121-131, 1993.

SWOFFORD, D. L. PAUP*: Phylogenetic analysis using parsimony (and other methods). Version 4. Sunderland, USA: Sinauer Associates, 2003.

TAJIMA, F. Statistical method for testing the neutral mutation hypothesis by DNA polymorphism. Genetics, v. 123, n. 3, p. 585-595, 1989.

TAKAHASHI, T.; OZAWA, K.; TAKAHASHI, K.; OKUNO, Y.; MUTO, Y.; TAKAKU, F.; ASANO, S. DNA replication of parvovirus B19 in a human erythroid leukemia cell line (JK1) in vitro. Arch. Virol., v. 131, n. 1/2, p. 201-208, 1993.

TAKAHASHI, Y.; MURAI, C.; SHIBATA, S.; MUNAKATA, Y.; ISHII, T.; ISHII, K.; SAITOH, T.; SAWAI, T.; SUGAMURA, K.; SASAKI, T. Human parvovirus B19 as a causative agent for rheumatoid arthritis. Proc. Natl. Acad. Sci. USA, v. 95, n. 14, p. 82278232, 1998.

THOMPSON, J. D.; HIGGINS, D. G.; GIBSON, T. J. Clustal W: improving the sensitivity of progressive multiple sequences alignment through sequence weighting, position-specific gap penalties and weight matrix choice. Nucleic Acids Res., v. 22, n. 22, p. 4673-4680, 1994.

TOAN, N. L.; DUECHTING, A.; KRENSNER, P. J.; SONGLE, H.; EDINGER, N.; ADERLE, S.; BING, V. Q.; DUY, D. N.; TORRESI, J.; KANDOLF, R.; BOCK, C. T. Phylogenetic analysis of human parvovirus B19, indicating two subgroups of genotypes 1 in Vietnamise patients. J. Gen. Virol., v. 87, Pt 10, p. 2941-2949, 2006a.

TOAN, N. L.; SONG LE, H.; KREMSNER, P. G.; DUY, D. N.; BINH, V. Q.; DUECHTING, A.; KAISER, H.; TORRESI, J.; KONDOLF, R.; BOCK, C.T. Co-infection of human 
parvovirus B19 in Vietnamese patients with hepatitis B virus infection. J. Hepatol., v 45, n. 3, p. 361-369, 2006b.

TSUJIMURA, M.; MATSUSHITA, K.; SHIRAKI, H.; SATO, H.; OKOCHI,K.; MAEDA, Y. Human parvovirus B19 infection in blood donors. Vox Sang., v. 69, n. 3, p. 206-212, 1995. UENO, Y.; UMADOMES, H.; SHIMODERA, M.; KISHIMOTO, I.; IKEGAYA, K.; YAMAUCHI, T. Human parvovirus B19 and arthritis. Lancet, v. 341, n. 8855, p. 1280, 1993.

UMENE, K.; NUNOUE, T. The genome type of human parvovirus B19 strains isolated in Japan during 1981 differs from types detected in 1986 to 1987: a correlation between genome type and prevalence. J. Gen. Virol., v. 71, Pt 4, p. 938-986, 1990.

VIEIRA, F. A. Avaliação da carga viral do parvovirus B19 em casos clínicos de eritema infeccioso provenientes de diferentes regiões do Brasil. 68f. Tese (Mestrado em Microbiologia) - Instituto de Ciências Biomédicas da Universidade de São Paulo, São Paulo, 2001.

VUORINEN, T.; LAMMINTAUSTA, K.; KOTILAINEN, P.; NIKKARI, S. Presence of parvovirus B19 DNA in chronic urticaric and healthy human skin. J. Clin. Virol., v. 25, n. 2, p. 217-221, 2002.

WALTERS, R. W.; AGBANDJE-MCKENNA, M.; BOWMAN, V. D.; MONINGER, T.O.; OLSON, N.H.; SEILER, M.; CHIORINI, J.A.; BEKER, T.S.; ZABNER, J. Structure of adeno-associated virus serotype 5. J. Virol., v. 78, n. 7, p. 3361-3371, 2004.

WANG, X.; ZHANG, G.; HAN, M.; CHAO, Q.; XU, D. Investigation of parvovirus B19 in cardiac tissue from patients with congenital heart disease. Chin. Med. J., v. 112, n. 11, p. 995-997, 1999.

WATANABE, T.; SATOH, M.; ODA, Y. Human parvovirus B19 encephalopathy. Arch. Dis. Child., v. 70, n. 1, p. 71, 1994.

WEIGEL-KELLY, K. A.; YODER, M. C.; SRIVASTAVA, A. Recombinant human parvovirus B19 vectors erythrocyte $\mathrm{P}$ antigen is necessary but not sufficient for successful transduction of human hematopoietic cells. J. Virol., v. 75, n. 9, p. 4110-4116, 2001.

WEILAND, H. T.; SALIMANS, M. M.; FIBBE, W. E.; KLUIN, P. M.; COHEN, B. J. Prolonged parvovirus B19 infection with severe anaemia in a bone marrow transplant patient. Br. J. Haematol., v. 71, n. 2, p. 300, 1989.

WHITE, D. G.; WOOLF, A. D.; MORTIMER, P. P.; COHEN, B. J.; BLAKE, D. R.; BACON, P. A. Human parvovirus arthropathy. Lancet, v. 1, n. 8426, p. 419-421, 1985.

WONG, S. F.; CHAN, F. Y.; CINCOTTA, R. B.; TILSE, M. Human parvovirus B19 infection in pregnancy: should screening be offered to low-risk population? Aust. N. Z. J. Obstet. Gynaecol , v. 42, n. 4, p. 347-351, 2002.

WOOLF, A. D. Human parvovirus B19 and arthritis. Behring Inst. Mitt., v. 85, p. 64-68, 1990. 
WOOLF, A. D.; CAMPION, G. V.; CHISHICK, A.; WISE, S.; COHEN, B. J.; KLOUDA. P. T.; CAUL, O.; DIEPPE, P. A. Clinical manifestations of human parvovirus B19 in adults. Arch. Intern. Med., v. 149, n. 5, p. 1153-1156, 1989.

XU, J.; RAFF, T. C.; MUALLEM, N. S.; NEUBERT, A. G. Hidrops fetalis secondary to parvovirus B19 infections. J. Am. Board Fam. Pract., v. 16, n. 1, p. 63-68, 2003.

YAEGASHI, N. Pathogenesis of nonimmune hydrops fetalis caused by intrauterine B19 infection. Tohoku J. Exp. Med., v. 190, n. 2, p. 65-82, 2000.

YAEGASHI, N.; SHIRAISHI, H.; TAKESHITA, T.; NAKAMURA, M.; YAJIMA, A.; SUGAMURA, K. Propagation of human parvovirus B19 in the primary culture of erythroid lineage cells derived from fetal liver. J. Virol., v. 63, n. 6, p. 2422-2426, 1989.

YANG, Z. PAML: a program package for phylogenetic analysis by maximum likelyhood. Comput. Appl. Biosci., v. 13, n. 5, p. 555-556, 1997.

YOTO, Y.; KUDOH, T.; HASEYAMA, K.; SUZUKI, N.; ODA, T.; KATOH, T.; TAKAHASHI, T.; SEKIGUCHI, S.; CHIBA, S. Incidence of human parvovirus B19 DNA detection in blood donors. Br. J. Haematol., v. 91, n. 4, p. 1017-1018, 1995.

YOTO, Y.; KUDON, T.; SUZUKI, N.; KATOH, S.; MATSUNAGA, Y.; CHIBA, S. Thrombocytopenia induced by human parvovirus B19 infections. Eur. J. Haematol., v. 50, n. 5, p. 255-257, 1993.

YOUNG, N. S. Parvovirus B19 infection and its treatment. Clin. Exp. Immunol., v. 104, p. 26-30, 1996. Supplement 1.

YOUNG, N. S. Parvoviruses. In: FIELDS, B. N.; KNIPE, D. M.; HOWLEY, P. N (Ed.). Fields Virology. 3. ed. Philadelphia: Lippincott-Raven Publishers, 1996. p. 2199-2220.

YOUNG, N. S.; MORTIMER, P. P.; MOORE, J. G.; HUMPHRIES, R. K. Characterization of a virus that causes transient aplastic crisis. J. Clin. Invest., v. 73, n. 1, p. 224-30, 1984.

ZAKRZEWSKA, K.; AZZI, A.; DE BIASI, E.; RADOSSI, P.; DE SANTIS, R.; DAVOLI, P. G.; TAGARIELLO, G. Persistence of parvovirus B19 DNA in synovium of patients with haemophilic arthritis. J. Med. Virol., v. 65, n. 2, p. 402-407, 2001.

ZERBINI, M.; CRICCA, M.; GENTILOMI, G.; VENTUROLI, S.; GALLINELLA, G.; MUSIANI, M. Tyramide signal amplification of biotinylated probe in dot-blot hybridization assay for detection of parvovirus B19 DNA in serum samples. Clin. Chim. Acta., v. 302, n. $1 / 2$, p. 79-87, 2000.

ZERBINI，M.; GALLINELLA，G.; MANARESI，E.; MUSIANI，M.; GENTILOMI，G.; VETUROLI, S. Standarzation of a PCR-ELISA in serum samples: diagnosis of active parvovirus B19 infection. J. Med. Virol., v. 59, n. 2, p. 2239-44, 1999.

ZERBINI, M.; GENTILOMI, G.; CRICCA, M.; MANARESI, E.; BONVICINI, F.; MUSIANI, M. A system to enhance the sensitivity of digoxigenin-labelled probe: detection of B19 DNA in serum sample. J. Virol. Methods, v. 93, n. 1/2, p. 137-144, 2001. 
ZERBINI, M.; MUSIANI, M.; VENTUROLI, S.; GALLINELLA, G.; GIBELLINI, D.; GENTILOMI, G. Different syndromes associated with B19 parvo virus viraemia in paediatric patiens: report of four cases. Eur. J. Pediatr., v. 151, n. 11, p. 815-817, 1992. 


\section{ANEXOS}


ANEXO 1 - Distribuição demográfica e resultados laboratoriais: ELISA, PCR e sequenciamento realizados em espécimes sorológicos de pacientes com sintomas sugestivos de infecção pelos eritrovírus de acordo idade e sexo, período de 1995-2005.

\begin{tabular}{|c|c|c|c|c|c|c|c|c|c|c|c|c|c|c|}
\hline & Registro & Sexo & Idade & $\begin{array}{l}\text { Tempo } \\
\text { doença }\end{array}$ & Quadro clínico & Espécime & Coleta & Local & & $\lg M$ & & $\lg G$ & PCR & Seq. \\
\hline 1 & 54.234 & $M$ & $23 a$ & $6 d$ & artropatia aguda & soro & 17.01 .95 & Belém & - & 0.116 & + & 1.578 & - & \\
\hline 2 & 54.286 & M & $4 a$ & $2 d$ & eritema infeccioso & soro & 19.01 .96 & Belém & - & 0.027 & - & 0.041 & - & \\
\hline 3 & 54.306 & M & $3 m$ & $6 d$ & febre, anemia falciforme & soro & 20.01 .95 & Belém & + & 1.108 & + & 0.310 & + & B19 \\
\hline 4 & 54.307 & $\mathrm{~F}$ & $3 a$ & $10 d$ & anemia falciforme. & soro & 20.01 .95 & Capanema & - & 0.090 & + & 0.146 & - & \\
\hline 5 & 54.363 & M & $8 m$ & $3 d$ & eritema infeccioso & soro & 26.01 .96 & Belém & - & 0.160 & - & 0.042 & + & B19 \\
\hline 6 & 54.525 & $\mathrm{~F}$ & $23 a$ & $2 d$ & artropatia aguda & soro & 13.02.95 & Belém & - & 0.231 & - & 0.059 & - & \\
\hline 7 & 54.581 & $\mathrm{~F}$ & $24 a$ & $2 d$ & artropatia aguda & soro & 16.02 .95 & Belém & - & 0.036 & - & 0.059 & - & \\
\hline 8 & 54.582 & M & $5 a$ & $4 d$ & eritema infeccioso & soro & 16.02 .95 & Icoaraci & - & 0.034 & - & 0.091 & - & \\
\hline 9 & 54.588 & $\mathrm{~F}$ & $4 \mathrm{~m}$ & $3 d$ & eritema infeccioso & soro & 16.02 .95 & Belém & - & 0.013 & - & 0.078 & - & \\
\hline 10 & 54.610 & $M$ & $3 m$ & $5 d$ & eritema infeccioso & soro & 20.02 .95 & Belém & - & 0.033 & - & 0.049 & - & \\
\hline 11 & 54.637 & $M$ & $8 m$ & $7 d$ & eritema infeccioso & soro & 22.02 .95 & Belém & + & 0.404 & - & 0.050 & + & B19 \\
\hline 12 & 54.638 & M & $9 a$ & $8 d$ & eritema infeccioso & soro & 22.02 .95 & Belém & - & 0.029 & + & 0.294 & - & \\
\hline 13 & 54.639 & $M$ & $8 a$ & $7 d$ & eritema infeccioso & soro & 22.02 .95 & Ananindeua & - & 0.102 & + & 0.476 & - & \\
\hline 14 & 54.716 & $\mathrm{~F}$ & $28 a$ & $2 d$ & eritema infeccioso & soro & 06.03 .95 & Belém & - & 0.024 & - & 0.179 & - & \\
\hline 15 & 54.781 & $\mathrm{~F}$ & $10 \mathrm{~m}$ & $4 d$ & eritema infeccioso & soro & 13.03 .95 & Icoaraci & - & 0.206 & - & 0.085 & - & \\
\hline 16 & 54.852 & $\mathrm{~F}$ & $6 a$ & $2 d$ & eritema infeccioso & soro & 20.03 .95 & Belém & - & 0.079 & - & 0.145 & - & \\
\hline 17 & 54.866 & $M$ & $8 a$ & $3 d$ & eritema infeccioso & plasma & 21.03 .95 & Belém & - & 0.018 & - & 0.119 & - & \\
\hline 18 & 54.923 & $\mathrm{~F}$ & $6 a$ & $4 d$ & eritema infeccioso & soro & 28.03 .95 & Belém & - & 0.020 & - & 0.082 & - & \\
\hline 19 & 54.926 & M & $3 a$ & $3 d$ & eritema infeccioso & soro & 28.03 .95 & Belém & - & 0.025 & - & 0.169 & - & \\
\hline 20 & 54.954 & $\mathrm{~F}$ & $26 a$ & $5 d$ & eritema infeccioso & soro & 30.03 .95 & Belém & - & 0.040 & - & 0.829 & - & \\
\hline 21 & 55.147 & M & $1 \mathrm{a}$ & $4 d$ & eritema infeccioso & soro & 11.04 .95 & Belém & - & 0.105 & - & 0.079 & - & \\
\hline 22 & 55.424 & $\mathrm{~F}$ & $13 a$ & $7 d$ & artropatia aguda & soro & 08.05 .96 & Belém & - & 0.056 & + & 2.522 & - & \\
\hline 23 & 55.436 & $M$ & $7 a$ & $3 d$ & eritema infeccioso & soro & 09.05 .95 & Belém & - & 0.130 & - & 0.042 & - & \\
\hline
\end{tabular}




\begin{tabular}{|c|c|c|c|c|c|c|c|c|c|c|c|c|c|c|}
\hline & Registro & Sexo & Idade & \begin{tabular}{|l|} 
Tempo \\
doença
\end{tabular} & Quadro clínico & Espécime & Coleta & Local & & $\lg M$ & & $\lg G$ & PCR & Seq. \\
\hline 24 & 55.537 & $\mathrm{~F}$ & $38 a$ & $7 d$ & eritema infeccioso & soro & \begin{tabular}{|l|}
18.05 .95 \\
\end{tabular} & Belém & - & 0.089 & - & 0.087 & - & \\
\hline 25 & 55.555 & $M$ & $12 \mathrm{a}$ & $8 d$ & eritema infeccioso & soro & 18.05.95 & Belém & + & 0.557 & + & 1.646 & + & $\mathrm{B} 19$ \\
\hline 26 & 55.625 & $\mathrm{~F}$ & $1 \mathrm{a}$ & $4 d$ & eritema infeccioso & soro & 25.05 .95 & Belém & - & 0.103 & - & 0.100 & - & \\
\hline 27 & 55.581 & M & $2 a$ & $4 d$ & eritema infeccioso & soro & 22.05 .95 & Belém & - & 0.112 & - & 0.084 & - & \\
\hline 28 & 55.583 & $M$ & $2 a$ & $5 d$ & eritema infeccioso & soro & 23.05.95 & Belém & - & 0.040 & + & 0.295 & - & \\
\hline 29 & 55.588 & $M$ & $4 a$ & $5 d$ & eritema infeccioso & soro & 24.05 .95 & Belém & - & 0.014 & - & 0.096 & - & \\
\hline 30 & 55.720 & M & $8 m$ & $5 d$ & eritema infeccioso & soro & 01.06 .95 & Ananindeua & - & 0.203 & - & 0.060 & + & $\mathrm{B} 19$ \\
\hline 31 & 55.757 & $\mathrm{~F}$ & $10 a$ & $8 d$ & eritema infeccioso & soro & 06.06.95 & Belém & - & 0.030 & + & 0.309 & - & \\
\hline 32 & 55.758 & $\mathrm{M}$ & $5 a$ & $2 d$ & eritema infeccioso & soro & 06.06.95 & Belém & - & 0.041 & - & 0.059 & - & \\
\hline 33 & 55.799 & $M$ & $22 a$ & $7 d$ & eritema infeccioso & plasma & 07.06.95 & Ananindeua & - & 0.008 & + & 0.360 & - & \\
\hline 34 & 55.853 & $\mathrm{~F}$ & $9 m$ & $5 d$ & eritema infeccioso & soro & 12.06.95 & Belém & - & 0.191 & - & 0.143 & + & B19 \\
\hline 35 & 55.866 & $\mathrm{~F}$ & $10 a$ & $7 d$ & eritema infeccioso & soro & 13.06.95 & Belém & + & 0.347 & - & 0.016 & + & B19 \\
\hline 36 & 55.980 & M & $8 m$ & $3 d$ & eritema infeccioso & soro & 22.06 .95 & Ananindeua & - & 0.096 & - & 0.103 & - & \\
\hline 37 & 56.006 & $\mathrm{~F}$ & $8 a$ & $6 d$ & eritema infeccioso & soro & 26.06 .95 & Ananindeua & - & 0.121 & - & 0.067 & - & \\
\hline 38 & 56.043 & $\mathrm{~F}$ & $8 a$ & $2 d$ & eritema infeccioso & soro & 28.06 .95 & Belém & - & 0.119 & + & 3.037 & - & \\
\hline 39 & 56.148 & $\mathrm{~F}$ & $20 a$ & $3 d$ & artropatia aguda & soro & 30.07 .95 & Belém & - & 0.111 & + & 1.186 & - & \\
\hline 40 & 56.302 & $\mathrm{M}$ & $12 a$ & $5 d$ & eritema infeccioso & soro & 20.07 .95 & Belém & - & 0.202 & - & 0.082 & - & \\
\hline 41 & 56.329 & $\mathrm{~F}$ & $26 a$ & $8 d$ & eritema infeccioso & soro & 25.07 .95 & Belém & + & 2.871 & + & 0.761 & - & \\
\hline 42 & 56.532 & $M$ & $11 \mathrm{a}$ & $7 d$ & eritema infeccioso & soro & 11.08.95 & Belém & - & 0.143 & + & 1.084 & - & \\
\hline 43 & 56.568 & $\mathrm{M}$ & $9 m$ & $5 d$ & eritema infeccioso & soro & 16.08.95 & Barcarena & + & 0.560 & - & 0.060 & - & \\
\hline 44 & 56.734 & $M$ & $6 m$ & $7 d$ & eritema infeccioso & soro & 30.08 .95 & Belém & - & 0.154 & - & 0.076 & - & \\
\hline 45 & 56.854 & $M$ & $8 m$ & $6 d$ & eritema infeccioso & soro & 13.09.95 & Belém & - & 0.062 & + & 0.360 & - & \\
\hline 46 & 56.998 & $\mathrm{M}$ & $8 m$ & $2 d$ & eritema infeccioso & soro & 27.09 .95 & Belém & - & 0.102 & - & 0.049 & - & \\
\hline 47 & 57.024 & $\mathrm{M}$ & $11 \mathrm{~m}$ & $5 d$ & eritema infeccioso & soro & 02.10 .95 & Belém & - & 0.192 & - & 0.114 & + & B19 \\
\hline 48 & 57.210 & $\mathrm{~F}$ & $9 m$ & $5 d$ & eritema infeccioso & soro & 20.10 .95 & Belém & + & 1.210 & - & 0.059 & - & \\
\hline 49 & 57.340 & $f$ & $4 a$ & $6 \mathrm{~d}$ & eritema infeccioso & soro & 06.11.95 & Belém & + & 0.286 & - & 0.055 & - & \\
\hline
\end{tabular}




\begin{tabular}{|c|c|c|c|c|c|c|c|c|c|c|c|c|c|c|}
\hline & Registro & Sexo & Idade & $\begin{array}{l}\text { Tempo } \\
\text { doença }\end{array}$ & Quadro clínico & Espécime & Coleta & Local & & $\lg M$ & & IgG & $\begin{array}{l}\text { (cont } \\
\text { PCR }\end{array}$ & Seq. \\
\hline 50 & 57.412 & $f$ & $19 a$ & $15 d$ & febre, anemia & soro & 13.11 .95 & Belém & - & 0.094 & - & 0.105 & - & \\
\hline 51 & 57.634 & $\mathrm{~F}$ & $11 \mathrm{~m}$ & $7 d$ & eritema infeccioso & soro & 05.12 .95 & Belém & + & 0.309 & - & 0.128 & + & $\mathrm{B} 19$ \\
\hline 52 & 57.656 & $\mathrm{~F}$ & $15 a$ & $15 d$ & febre, anemia aplástica & soro & 07.12 .95 & Belém & - & 0.028 & + & 0.463 & - & \\
\hline 53 & 57.741 & $\mathrm{M}$ & $9 m$ & $9 d$ & febre, anemia falciforme & soro & 19.12.95 & Belém & + & 0.565 & + & 2.956 & + & B19 \\
\hline 54 & 58.038 & $\mathrm{~F}$ & $25 a$ & $7 d$ & eritema infeccioso & soro & 31.01 .96 & Belém & + & 0.280 & + & 0.179 & - & \\
\hline 55 & 58.222 & $\mathrm{~F}$ & $28 a$ & $10 d$ & artropatia aguda & soro & 26.02 .96 & Belém & - & 0.053 & - & 0.059 & - & \\
\hline 56 & 58.243 & $\mathrm{~F}$ & $5 a$ & $15 d$ & febre, anemia falciforme & soro & 28.02 .96 & Abaetetuba & - & 0.118 & - & 0.100 & - & \\
\hline 57 & 58.277 & $\mathrm{M}$ & $33 a$ & $10 d$ & febre, anemia & soro & 01.03 .96 & Belém & - & 0.219 & + & 0.536 & - & \\
\hline 58 & 58.462 & $\mathrm{~F}$ & $16 a$ & $9 d$ & febre, anemia hemolítica crônica & soro & 21.03 .96 & Marituba & + & 0.354 & + & 0.535 & - & \\
\hline 59 & 58.476 & $\mathrm{~F}$ & $2 a$ & $10 d$ & eritema infeccioso & soro & 25.03 .96 & Belém & - & 0.066 & - & 0.045 & - & \\
\hline 60 & 58.602 & $\mathrm{~F}$ & $53 a$ & $7 d$ & artropatia aguda & soro & 09.04 .96 & Belém & - & 0.072 & + & 1.079 & - & \\
\hline 61 & 58.638 & $\mathrm{M}$ & $42 a$ & $8 d$ & eritema infeccioso & plasma & 11.04 .96 & Ananindeua & - & 0.097 & - & 0.049 & - & \\
\hline 62 & 58.796 & $\mathrm{~F}$ & $4 a$ & $6 d$ & eritema infeccioso & soro & 24.04 .96 & Belém & - & 0.070 & - & 0.059 & - & \\
\hline 63 & 58.799 & $\mathrm{M}$ & $9 a$ & $7 d$ & eritema infeccioso & soro & 24.04 .96 & Belém & - & 0.190 & - & 0.103 & - & \\
\hline 64 & 59.289 & $\mathrm{M}$ & $2 a$ & $10 d$ & febre, anemia falciforme & soro & 06.06 .96 & Ananindeua & - & 0.349 & - & 0.101 & - & \\
\hline 65 & 59.297 & $\mathrm{~F}$ & $30 a$ & $9 d$ & artropatia aguda & soro & 07.06 .96 & Belém & + & 3.009 & + & 0.821 & + & B19 \\
\hline 66 & 59.336 & $\mathrm{~F}$ & $4 a$ & $5 d$ & eritema infeccioso & soro & 12.06 .96 & Belém & - & 0.138 & - & 0.045 & - & \\
\hline 67 & 59.706 & $\mathrm{~F}$ & $7 \mathrm{~m}$ & $7 d$ & eritema infeccioso & soro & 22.07 .96 & Belém & + & 0.450 & - & 0.051 & + & $\mathrm{B} 19$ \\
\hline 68 & 59.853 & $\mathrm{~F}$ & $9 a$ & $8 d$ & eritema infeccioso & soro & 07.08 .96 & Belém & - & 0.177 & + & 1.073 & - & \\
\hline 69 & 60.292 & $\mathrm{~F}$ & $7 a$ & $7 d$ & febre, púrpura trombocitopênica & soro & 27.09 .96 & Belém & + & 0.398 & - & 0.125 & + & B19 \\
\hline 70 & 60.506 & M & $11 \mathrm{~m}$ & $6 d$ & eritema infeccioso & soro & 22.10 .96 & Belém & - & 0.163 & - & 0.097 & - & \\
\hline 71 & 60.640 & $\mathrm{M}$ & $11 \mathrm{~m}$ & $7 d$ & eritema infeccioso & soro & 04.11 .96 & Belém & + & 0.360 & - & 0.105 & + & B19 \\
\hline 72 & 60.763 & $\mathrm{~F}$ & $25 a$ & $9 d$ & eritema infeccioso & soro & 13.11.96 & Belém & + & 1.895 & + & 1.110 & + & B19 \\
\hline 73 & 60.832 & $\mathrm{M}$ & $2 a$ & $10 \mathrm{~d}$ & anemia & soro & 22.11 .96 & Belém & + & 0.352 & + & 0.291 & - & \\
\hline 74 & 61.362 & $\mathrm{M}$ & $6 a$ & $7 d$ & eritema infeccioso & soro & 24.01 .97 & Belém & + & 0.755 & - & 0.115 & + & B19 \\
\hline 75 & 61.471 & $\mathrm{~F}$ & $26 a$ & $8 d$ & eritema infeccioso & soro & |07.02.97| & Belém & + & 0.430 & + & 0.964 & + & B19 \\
\hline
\end{tabular}




\begin{tabular}{|c|c|c|c|c|c|c|c|c|c|c|c|c|c|c|}
\hline & Registro & Sexo & Idade & $\begin{array}{l}\text { Tempo } \\
\text { doença }\end{array}$ & Quadro clínico & Espécime & Coleta & Local & & $\lg M$ & & $\lg G$ & PCR & Seq. \\
\hline 76 & 61.532 & $\mathrm{~F}$ & $3 m$ & $8 d$ & eritema infeccioso & soro & 19.02 .97 & Belém & + & 0.375 & + & 0.480 & + & B19 \\
\hline 77 & 61.995 & $\mathrm{~F}$ & $51 \mathrm{a}$ & $7 d$ & eritema infeccioso & soro & 04.04 .97 & Belém & - & 0.104 & + & 0.963 & - & \\
\hline 78 & 62.068 & M & 4 & $8 d$ & eritema infeccioso & soro & 11.04 .97 & Belém & + & 2.786 & + & 1.855 & + & D-91 \\
\hline 79 & 62.180 & $\mathrm{~F}$ & 7 & $7 d$ & eritema infeccioso & soro & 23.04 .97 & Belém & + & 0.688 & + & 1.281 & - & \\
\hline 80 & 62.218 & $M$ & $20 a$ & $8 d$ & artropatia aguda & soro & 28.04 .97 & Belém & - & 0.210 & - & 0.103 & - & \\
\hline 81 & 62.342 & M & $2 a$ & $8 d$ & anemia falciforme & soro & 09.05 .97 & Belém & - & 0.160 & + & 1.480 & + & $\mathrm{B} 19$ \\
\hline 82 & 62.344 & M & $14 a$ & $8 d$ & eritema infeccioso & soro & 09.05 .97 & Belém & - & 0.157 & + & 1.806 & + & B19 \\
\hline 83 & 62.441 & $\mathrm{~F}$ & $10 a$ & $7 d$ & artropatia aguda & soro & 19.05 .97 & Belém & - & 0.067 & + & 0.326 & - & \\
\hline 84 & 62.457 & $\mathrm{~F}$ & $1 \mathrm{a}$ & $7 d$ & eritema infeccioso & soro & 20.05 .97 & Belém & + & 0.440 & + & 1.136 & + & B19 \\
\hline 85 & 62.587 & $M$ & $4 a$ & $4 d$ & eritema infeccioso & soro & 02.06.97 & Belém & - & 0.138 & - & 0.053 & - & \\
\hline 86 & 62.782 & $M$ & $8 a$ & $8 d$ & eritema infeccioso & soro & 17.06.97 & Belém & + & 1.655 & + & 0.796 & + & $\mathrm{B} 19$ \\
\hline 87 & 62.826 & $\mathrm{~F}$ & $2 a$ & $5 d$ & eritema infeccioso & soro & 23.06 .97 & Belém & - & 0.089 & + & 0.332 & - & \\
\hline 88 & 62.850 & $M$ & $7 a$ & $9 d$ & esferocitose congênita & soro & 24.06 .97 & Belém & - & 0.157 & + & 0.386 & + & B19 \\
\hline 89 & 62.967 & M & $9 a$ & $7 d$ & eritema infeccioso & soro & 04.07.97 & Belém & + & 0.481 & + & 1.027 & + & $\mathrm{B} 19$ \\
\hline 90 & 62.982 & $\mathrm{~F}$ & $16 a$ & $4 d$ & eritema infeccioso & soro & 08.07.97 & Marituba & - & 0.232 & - & 0.051 & + & $\mathrm{B} 19$ \\
\hline 91 & 62.993 & $\mathrm{~F}$ & $22 a$ & $16 d$ & artropatia aguda & soro & 09.07 .97 & Belém & - & 0.109 & + & 1.966 & - & \\
\hline 92 & 63.003 & M & $27 a$ & $10 d$ & artropatia aguda & soro & 10.07.97 & Ananindeua & + & 0.910 & + & 2.624 & - & \\
\hline 93 & 63.031 & $\mathrm{~F}$ & $26 a$ & $16 d$ & febre, anemia hemolitica crônica & plasma & 14.07.97 & Belém & - & 0.086 & + & 0.170 & - & \\
\hline 94 & 63.118 & M & $4 a$ & $6 d$ & eritema infeccioso & soro & 22.07 .97 & Belém & + & 0.668 & + & 0.927 & - & \\
\hline 95 & 63.204 & $\mathrm{~F}$ & $3 a$ & $7 d$ & eritema infeccioso & soro & 01.08 .97 & Santa Isabel & + & 0.585 & + & 0.682 & - & \\
\hline 96 & 63.232 & $\mathrm{~F}$ & $45 a$ & $8 d$ & artropatia aguda & soro & 05.07 .97 & Belém & + & 0.366 & + & 0.226 & - & \\
\hline 97 & 63.311 & $\mathrm{~F}$ & $23 a$ & $15 d$ & anemia crônica & soro & 12.08 .97 & Belém & - & 0.069 & + & 1.133 & - & \\
\hline 98 & 63.313 & $\mathrm{M}$ & $4 a$ & $7 d$ & eritema infeccioso & soro & 13.08.97 & Marituba & + & 0.503 & - & 0.071 & + & B19 \\
\hline 99 & 63.335 & $\mathrm{M}$ & $8 a$ & $7 d$ & eritema infeccioso & soro & 14.08.97 & Belém & + & 0.354 & - & 0.078 & - & \\
\hline 100 & 63.416 & $M$ & $6 a$ & $8 d$ & eritema infeccioso & soro & 21.08 .97 & Ananindeua & + & 0.479 & + & 1.215 & + & D-91 \\
\hline
\end{tabular}




\begin{tabular}{|c|c|c|c|c|c|c|c|c|c|c|c|c|c|c|}
\hline & Registro & Sexo & Idade & $\begin{array}{l}\text { Tempo } \\
\text { doença }\end{array}$ & Quadro clínico & Espécime & Coleta & Local & & $\lg M$ & & $\lg G$ & PCR & Seq. \\
\hline 101 & 63.478 & $\mathrm{~F}$ & $40 a$ & $8 d$ & artropatia aguda & soro & 26.08 .97 & Abaetetuba & - & 0.045 & + & 2.735 & - & \\
\hline 102 & 63.527 & $\mathrm{~F}$ & $59 a$ & $10 d$ & encefalite, crises convulsivas & soro & 29.08 .97 & Belém & - & 0.018 & - & 0.130 & - & \\
\hline 103 & 63.555 & $\mathrm{M}$ & $1 \mathrm{a}$ & $7 d$ & eritema infeccioso & soro & 02.09.97 & Belém & - & 0.186 & - & 0.049 & - & \\
\hline 104 & 63.560 & $M$ & $1 \mathrm{a}$ & $7 d$ & eritema infeccioso & soro & 02.09.97 & Belém & - & 0.220 & - & 0.054 & - & \\
\hline 105 & 63.586 & $\mathrm{M}$ & $27 a$ & $8 d$ & artropatia aguda & soro & 04.09.97 & Ananindeua & - & 0.141 & + & 1.667 & - & \\
\hline 106 & 63.619 & $\mathrm{~F}$ & $12 a$ & $6 d$ & artropatia aguda & soro & 08.09.97 & Belém & - & 0.118 & + & 2.377 & - & \\
\hline 107 & 63.660 & $\mathrm{~F}$ & $2 a$ & $20 d$ & febre,anemia,aplasia medular & soro & 10.09.97 & Belém & - & 0.075 & - & 0.082 & - & \\
\hline 108 & 63.865 & $\mathrm{~F}$ & $37 a$ & $8 d$ & febre, anemia & soro & 23.09.97 & Belém & + & 1.691 & + & 1.003 & + & $\mathrm{B} 19$ \\
\hline 109 & 63.988 & $\mathrm{~F}$ & $7 a$ & $6 d$ & eritema infeccioso & soro & \begin{tabular}{|l|}
30.09 .97 \\
\end{tabular} & Belém & - & 0.125 & - & 0.055 & - & \\
\hline 110 & 64.065 & $M$ & $6 a$ & $5 d$ & eritema infeccioso & soro & 06.10.97 & Belém & - & 0.103 & + & 0.132 & - & \\
\hline 111 & 64.068 & $\mathrm{~F}$ & $6 a$ & $8 d$ & eritema infeccioso & soro & 06.10 .97 & Belém & - & 0.052 & - & 0.048 & - & \\
\hline 112 & 64.467 & $\mathrm{M}$ & $9 a$ & $6 d$ & eritema infeccioso & soro & 06.11.97 & Marituba & - & 0.141 & + & 1.688 & - & \\
\hline 113 & 64.520 & $\mathrm{~F}$ & $25 a$ & $9 d$ & eritema infeccioso & soro & 11.11.97 & Ananindeua & + & 0.540 & + & 1.082 & - & \\
\hline 114 & 64.777 & $\mathrm{~F}$ & $2 a$ & $5 d$ & eritema infeccioso & soro & 25.11.97 & Ananindeua & - & 0.178 & - & 0.092 & - & \\
\hline 115 & 64.972 & $\mathrm{M}$ & $4 a$ & $7 d$ & eritema infeccioso & soro & 05.12.97 & Belém & - & 0.060 & - & 0.076 & - & \\
\hline 116 & 65.033 & $\mathrm{~F}$ & $27 a$ & $15 d$ & febre,lupus eritematoso sistêmico & soro & 11.12.97 & Ananindeua & - & 0.014 & + & 0.175 & - & \\
\hline 117 & 65.110 & $\mathrm{~F}$ & $27 \mathrm{a}$ & $12 d$ & anemia falciforme & plasma & 16.12.97 & Belém & - & 0.082 & + & 1.536 & - & \\
\hline 118 & 65.112 & $\mathrm{~F}$ & $13 a$ & $9 d$ & eritema infeccioso & soro & 16.12.97 & Belém & - & 0.090 & + & 1.033 & - & \\
\hline 119 & 65.115 & $\mathrm{~F}$ & $9 a$ & $8 d$ & eritema infeccioso & soro & 16.12.97 & Belém & + & 0.630 & + & 0.784 & + & B19 \\
\hline 120 & 65.132 & $\mathrm{~F}$ & $44 a$ & $11 d$ & artropatia aguda & soro & 16.12.97 & Belém & - & 0.087 & + & 1.626 & - & \\
\hline 121 & 65.199 & $\mathrm{~F}$ & $45 a$ & $7 d$ & artropatia aguda & soro & 22.12.97 & Belém & + & 2.701 & + & 0.347 & + & $\mathrm{B} 19$ \\
\hline 122 & 65.201 & $\mathrm{~F}$ & $9 a$ & $8 d$ & eritema infeccioso & soro & 22.12.97 & Belém & + & 0.321 & - & 0.079 & - & \\
\hline 123 & 65.294 & $M$ & $8 a$ & $7 d$ & eritema infeccioso & soro & 05.01.98 & Belém & + & 0.466 & - & 0.172 & - & \\
\hline 124 & 65.295 & $\mathrm{M}$ & $5 a$ & $10 d$ & eritema infeccioso & soro & 05.01.98 & Belém & + & 0.359 & + & 1.457 & - & \\
\hline 125 & 65.300 & $\mathrm{~F}$ & $19 a$ & $6 d$ & eritema infeccioso & soro & 05.01.98 & Belém & + & 0.381 & - & 0.104 & - & \\
\hline 126 & 65.417 & $\mathrm{~F}$ & $6 a$ & $5 d$ & eritema infeccioso & soro & 12.01.98 & Belém & + & 0.439 & - & 0.121 & - & \\
\hline
\end{tabular}




\begin{tabular}{|c|c|c|c|c|c|c|c|c|c|c|c|c|c|c|}
\hline & Registro & Sexo & Idade & $\begin{array}{l}\text { Tempo } \\
\text { doença }\end{array}$ & Quadro clínico & Espécime & Coleta & Local & & $\lg M$ & & $\lg G$ & $\begin{array}{l}\text { (cont } \\
\text { PCR }\end{array}$ & $\begin{array}{l}\text { nuaçã } \\
\text { Seq. }\end{array}$ \\
\hline 127 & 65.610 & $\mathrm{~F}$ & $15 a$ & $8 d$ & eritema infeccioso & soro & 22.01 .98 & Belém & + & 1.453 & + & 0.883 & - & \\
\hline 128 & 65.626 & $\mathrm{~F}$ & $29 a$ & $14 d$ & anemia crônica & soro & 23.01 .98 & Baião & - & 0.060 & + & 0.410 & - & \\
\hline 129 & 65.819 & $\mathrm{M}$ & $10 a$ & $7 d$ & eritema infeccioso & soro & 10.02 .98 & Belém & + & 0.919 & + & 2.032 & - & \\
\hline 130 & 65.826 & $\mathrm{~F}$ & $1 \mathrm{a}$ & $10 \mathrm{~d}$ & anemia & soro & 10.02 .98 & Belém & - & 0.039 & - & 0.077 & - & \\
\hline 131 & 65.889 & $\mathrm{~F}$ & $1 \mathrm{~m}$ & $8 d$ & anemia & soro & 13.02 .98 & Ananindeua & - & 0.171 & - & 0.004 & - & \\
\hline 132 & 66.016 & $\mathrm{~F}$ & $22 a$ & $7 d$ & artropatia aguda & soro & 03.03 .98 & Belém & - & 0.104 & + & 1.380 & - & \\
\hline 133 & 66.147 & $\mathrm{~F}$ & $8 a$ & $10 d$ & febre,anemia falciforme & soro & 17.03 .98 & Belém & + & 2.179 & + & 1.374 & + & $\mathrm{B} 19$ \\
\hline 134 & 66.216 & $\mathrm{~F}$ & $5 a$ & $6 \mathrm{~d}$ & febre,anemia falciforme & soro & 20.03 .98 & Belém & + & 0.350 & - & 0.049 & - & \\
\hline 135 & 66.354 & $\mathrm{M}$ & $5 a$ & $8 d$ & eritema infeccioso & soro & 08.04 .98 & Belém & + & 1.147 & + & 0.684 & + & $\mathrm{B} 19$ \\
\hline 136 & 66.462 & $\mathrm{~F}$ & $45 a$ & $11 d$ & artropatia aguda & soro & 24.04 .98 & Bragança & - & 0.012 & + & 1.020 & - & \\
\hline 137 & 66.525 & $\mathrm{M}$ & $11 \mathrm{a}$ & $8 d$ & eritema infeccioso & soro & 04.05 .98 & Belém & + & 0.693 & + & 1.176 & + & $\mathrm{B} 19$ \\
\hline 138 & 66.594 & $\mathrm{~F}$ & $4 a$ & $6 \mathrm{~d}$ & eritema infeccioso & soro & 12.05 .98 & Belém & + & 0.341 & + & 1.570 & - & \\
\hline 139 & 66.600 & $\mathrm{~F}$ & $10 \mathrm{a}$ & $7 d$ & eritema infeccioso & soro & 12.05 .98 & Belém & + & 0.448 & + & 1.120 & + & $\mathrm{B} 19$ \\
\hline 140 & 66.712 & $\mathrm{~F}$ & $6 a$ & $15 d$ & púrpura trombocitopênica & soro & 22.05 .98 & Belém & - & 0.113 & + & 0.381 & - & \\
\hline 141 & 66.967 & $\mathrm{~F}$ & $29 a$ & $9 d$ & artropatia aguda & soro & 18.06 .98 & Belém & + & 2.162 & + & 1.804 & + & $\mathrm{B} 19$ \\
\hline 142 & 67.042 & $\mathrm{~F}$ & $11 \mathrm{a}$ & $8 d$ & eritema infeccioso & soro & 23.06 .98 & Belém & + & 0.507 & + & 0.034 & - & \\
\hline 143 & 67.046 & $\mathrm{M}$ & $6 a$ & $6 d$ & eritema infeccioso & soro & 23.06 .98 & Ananindeua & + & 0.473 & + & 0.020 & - & \\
\hline 144 & 67.370 & $\mathrm{~F}$ & $9 a$ & $8 d$ & eritema infeccioso & soro & 16.07.98 & Marituba & + & 0.522 & + & 0.045 & - & \\
\hline 145 & 67.401 & $\mathrm{~F}$ & $8 a$ & $6 d$ & artropatia aguda & soro & 20.07 .98 & Belém & + & 0.461 & + & 0.257 & - & \\
\hline 146 & 67.432 & $\mathrm{~F}$ & $12 a$ & $8 d$ & artropatia aguda & soro & 23.10 .98 & Belém & + & 0.504 & + & 0.073 & - & \\
\hline 147 & 67.530 & $\mathrm{M}$ & $4 a$ & $7 d$ & eritema infeccioso & soro & 03.08.98 & Belém & + & 0.888 & + & 0.041 & - & \\
\hline 148 & 67.670 & $\mathrm{~F}$ & $5 \mathrm{~m}$ & $6 d$ & eritema infeccioso & soro & 14.08 .98 & Belém & + & 0.356 & + & 0.353 & - & \\
\hline 149 & 67.831 & $\mathrm{~F}$ & $1 \mathrm{a}$ & $18 d$ & anemia falciforme & soro & 31.08 .98 & Belém & + & 0.279 & - & 0.129 & - & \\
\hline 150 & 68.033 & $\mathrm{M}$ & $2 a$ & $4 d$ & eritema infeccioso & plasma & 21.09 .98 & Belém & - & 0.207 & - & 0.030 & - & \\
\hline 151 & 68.109 & $\mathrm{~F}$ & $58 a$ & $9 d$ & eritema infeccioso & soro & 28.09 .98 & Belém & + & 0.440 & + & 0.085 & - & \\
\hline 152 & 68.112 & $\mathrm{M}$ & $23 a$ & $7 d$ & eritema infeccioso & soro & 28.09 .98 & Belém & + & 0.785 & + & 0.736 & - & \\
\hline
\end{tabular}




\begin{tabular}{|c|c|c|c|c|c|c|c|c|c|c|c|c|c|c|}
\hline & Registro & Sexo & Idade & $\begin{array}{l}\text { Tempo } \\
\text { doença }\end{array}$ & Quadro clínico & Espécime & Coleta & Local & & $\lg M$ & & $\lg G$ & $\begin{array}{l}\text { (cont } \\
\text { PCR }\end{array}$ & $\begin{array}{l}\text { nuaçã } \\
\text { Seq. }\end{array}$ \\
\hline 153 & 68.255 & $M$ & $2 m$ & $15 d$ & trombocitopenia & soro & 09.10 .98 & Belém & - & 0.070 & + & 0.399 & - & \\
\hline 154 & 68.293 & $\mathrm{~F}$ & $20 a$ & $10 d$ & artropatia aguda & soro & 18.12.97 & Belém & - & 0.027 & + & 1.283 & - & \\
\hline 155 & 68.499 & $\mathrm{M}$ & $10 \mathrm{~m}$ & $10 d$ & anemia & soro & 30.10 .98 & Santarém & - & 0.020 & - & 0.158 & - & \\
\hline 156 & 68.514 & $\mathrm{~F}$ & $5 a$ & $8 d$ & artropatia aguda & soro & 03.11 .98 & Ananindeua & + & 3.158 & + & 0.821 & + & D-91 \\
\hline 157 & 68.633 & $\mathrm{M}$ & $22 a$ & $9 d$ & artropatia aguda & soro & 13.11.98 & Ananindeua & + & 0.450 & + & 0.664 & + & B19 \\
\hline 158 & 68.668 & $\mathrm{~F}$ & $29 a$ & $5 d$ & eritema infeccioso & soro & 16.11.98 & Belém & - & 0.093 & + & 1.315 & - & \\
\hline 159 & 68.888 & $\mathrm{~F}$ & $4 a$ & $7 d$ & eritema infeccioso & soro & 03.12 .98 & Belém & + & 0.744 & - & 0.011 & - & \\
\hline 160 & 68.905 & $M$ & $11 \mathrm{a}$ & $7 d$ & eritema infeccioso & soro & 04.12 .98 & Belém & + & 0.367 & - & 0.032 & - & \\
\hline 161 & 68.916 & M & $7 a$ & $8 d$ & eritema infeccioso & soro & 07.12.98 & Belém & + & 0.335 & - & 0.018 & - & \\
\hline 162 & 69.078 & $\mathrm{~F}$ & $21 \mathrm{a}$ & $10 d$ & artropatia aguda & soro & 21.12 .98 & Benevides & + & 2.868 & + & 1.165 & + & $\mathrm{B} 19$ \\
\hline 163 & 69.214 & M & $11 \mathrm{a}$ & $6 d$ & eritema infeccioso & soro & 07.01.99 & Belém & + & 0.464 & + & 0.332 & - & \\
\hline 164 & 69.246 & M & $7 a$ & $9 d$ & eritema infeccioso & soro & 11.01.99 & Belém & + & 0.341 & - & 0.022 & - & \\
\hline 165 & 69.290 & $\mathrm{M}$ & $26 a$ & $8 d$ & eritema infeccioso & soro & 14.01 .99 & Belém & + & 0.499 & - & 0.041 & - & \\
\hline 166 & 69.369 & $M$ & $7 a$ & $6 d$ & eritema infeccioso & soro & 21.01 .99 & Belém & + & 0.494 & + & 0.340 & - & \\
\hline 167 & 69.419 & M & $3 a$ & $11 d$ & anemia & soro & 26.01 .99 & Ananindeua & + & 0.452 & - & 0.132 & - & \\
\hline 168 & 69.510 & $\mathrm{~F}$ & $26 \mathrm{a}$ & $5 d$ & eritema infeccioso & soro & 01.02 .99 & Belém & + & 0.340 & - & 0.016 & - & \\
\hline 169 & 69.707 & M & $1 \mathrm{a}$ & $6 d$ & eritema infeccioso & soro & 21.02 .99 & Belém & + & 0.590 & - & 0.026 & - & \\
\hline 170 & 69.804 & M & $17 \mathrm{a}$ & $10 d$ & eritema infeccioso & soro & 01.03.99 & Belém & + & 0.340 & + & 0.889 & - & \\
\hline 171 & 69.807 & $\mathrm{~F}$ & $11 \mathrm{a}$ & $6 d$ & eritema infeccioso & soro & 02.03.99 & Belém & + & 0.404 & - & 0.105 & - & \\
\hline 172 & 69.881 & $\mathrm{~F}$ & $1 \mathrm{a}$ & $10 d$ & púrpura trombocotopênica & soro & 04.03 .99 & Barcarena & + & 0.822 & + & 0.363 & + & $\mathrm{B} 19$ \\
\hline 173 & 70.024 & $\mathrm{~F}$ & $11 \mathrm{a}$ & $7 d$ & artropatia aguda & soro & 15.03 .99 & Belém & + & 0.365 & - & 0.019 & - & \\
\hline 174 & 70.183 & $\mathrm{~F}$ & $1 \mathrm{a}$ & $10 d$ & anemia hemolítica crônica & soro & 26.03 .99 & Belém & + & 0.857 & - & 0.092 & - & \\
\hline 175 & 70.200 & $\mathrm{~F}$ & $4 a$ & $6 d$ & eritema infeccioso & soro & 29.03 .99 & Mosqueiro & + & 0.327 & - & 0.015 & - & \\
\hline 176 & 70.320 & $\mathrm{~F}$ & $9 a$ & $7 d$ & eritema infeccioso & soro & 09.04.99 & Belém & + & 2.883 & - & 0.089 & + & B19 \\
\hline 177 & 70.326 & M & $6 a$ & $7 d$ & eritema infeccioso & soro & \begin{tabular}{|l|}
09.04 .99 \\
\end{tabular} & Belém & + & 1.878 & + & 0.270 & + & B19 \\
\hline
\end{tabular}




\begin{tabular}{|c|c|c|c|c|c|c|c|c|c|c|c|c|c|c|}
\hline & Registro & Sexo & Idade & $\begin{array}{l}\text { Tempo } \\
\text { doença }\end{array}$ & Quadro clínico & Espécime & Coleta & Local & & $\lg M$ & & $\lg G$ & PCR & Seq. \\
\hline 178 & 70.413 & $\mathrm{~F}$ & $11 \mathrm{a}$ & $7 d$ & eritema infeccioso & soro & 19.04 .99 & Belém & + & 0.987 & + & 1.400 & - & \\
\hline 179 & 70.416 & $\mathrm{~F}$ & $25 a$ & $6 d$ & artropatia aguda & soro & 19.04 .99 & Belém & + & 0.393 & - & 0.109 & - & \\
\hline 180 & 70.423 & $M$ & $3 a$ & $6 \mathrm{~d}$ & eritema infeccioso & soro & 19.04 .99 & Ananindeua & + & 0.370 & + & 1.611 & - & \\
\hline 181 & 70.430 & $\mathrm{M}$ & $5 a$ & $8 d$ & eritema infeccioso & soro & 20.04 .99 & Belém & + & 0.573 & - & 0.015 & - & \\
\hline 182 & 70.438 & $\mathrm{~F}$ & $11 \mathrm{a}$ & $7 d$ & eritema infeccioso & soro & 20.04 .99 & Belém & + & 0.505 & - & 0.021 & - & \\
\hline 183 & 70.606 & $\mathrm{~F}$ & $15 a$ & $8 d$ & eritema infeccioso & soro & 28.04 .99 & Ananindeua & + & 0.388 & + & 1.719 & - & \\
\hline 184 & 70.645 & $\mathrm{~F}$ & $31 \mathrm{a}$ & $6 d$ & artropatia aguda & soro & 30.04 .99 & Belém & - & 0.060 & + & 1.898 & - & \\
\hline 185 & 70.795 & $\mathrm{~F}$ & $8 a$ & $6 \mathrm{~d}$ & artropatia aguda & soro & 13.05.99 & Belém & + & 0.565 & + & 1.878 & - & \\
\hline 186 & 70.802 & $\mathrm{M}$ & $17 \mathrm{a}$ & $9 d$ & eritema infeccioso & soro & 13.05.99 & Belém & + & 0.395 & + & 1.920 & - & \\
\hline 187 & 70.834 & $\mathrm{~F}$ & $3 a$ & $6 d$ & eritema infeccioso & soro & 14.05 .99 & Ananindeua & - & 0.088 & - & 0.170 & - & \\
\hline 188 & 70.881 & $\mathrm{~F}$ & $22 \mathrm{a}$ & $7 d$ & artropatia aguda & soro & 20.05 .99 & Belém & + & 0.464 & - & 0.075 & - & \\
\hline 189 & 70.895 & $\mathrm{M}$ & $14 a$ & $8 d$ & eritema infeccioso & soro & 20.05 .99 & Belém & + & 0.750 & + & 0.375 & - & \\
\hline 190 & 70.953 & $\mathrm{M}$ & $24 a$ & $7 d$ & artropatia aguda & soro & 24.05 .99 & Belém & + & 0.536 & + & 1.582 & - & \\
\hline 191 & 70.956 & $\mathrm{M}$ & $14 a$ & $5 d$ & artropatia aguda & soro & 24.05 .99 & Belém & + & 0.704 & - & 0.089 & - & \\
\hline 192 & 70.964 & $\mathrm{~F}$ & $7 a$ & $9 d$ & eritema infeccioso & soro & 24.05 .99 & Belém & + & 1.430 & + & 1.021 & + & B19 \\
\hline 193 & 70.971 & $\mathrm{M}$ & $7 a$ & $7 d$ & eritema infeccioso & soro & 25.05 .99 & Belém & + & 0.320 & + & 0.362 & - & \\
\hline 194 & 70.995 & M & $8 a$ & $7 d$ & eritema infeccioso & soro & 25.05 .99 & Belém & + & 0.864 & + & 1.382 & + & $\mathrm{B} 19$ \\
\hline 195 & 70.998 & $\mathrm{~F}$ & $7 a$ & $6 \mathrm{~d}$ & eritema infeccioso & soro & 26.05 .99 & Belém & + & 0.366 & - & 0.128 & - & \\
\hline 196 & 71.009 & $\mathrm{~F}$ & $11 \mathrm{a}$ & $7 d$ & eritema infeccioso & soro & 27.05 .99 & Belém & + & 0.463 & - & 0.102 & - & \\
\hline 197 & 71.147 & $\mathrm{~F}$ & $6 a$ & $5 d$ & eritema infeccioso & soro & 07.06 .99 & Belém & - & 0.067 & - & 0.134 & - & \\
\hline 198 & 71.151 & $\mathrm{~F}$ & $14 a$ & $6 \mathrm{~d}$ & eritema infeccioso & soro & 07.06 .99 & Belém & + & 0.514 & - & 0.110 & - & \\
\hline 199 & 71.160 & $\mathrm{M}$ & $8 a$ & $6 \mathrm{~d}$ & eritema infeccioso & soro & 07.06 .99 & Belém & + & 0.321 & - & 0.074 & - & \\
\hline 200 & 71.175 & M & $8 a$ & $7 d$ & eritema infeccioso & soro & 08.06.99 & Belém & + & 0.754 & + & 1.537 & - & \\
\hline 201 & 71.247 & $\mathrm{M}$ & $10 \mathrm{a}$ & $8 d$ & artropatia aguda & soro & 11.06.99 & Belém & + & 1.198 & + & 2.023 & - & \\
\hline 202 & 71.296 & $\mathrm{~F}$ & $10 \mathrm{a}$ & $8 d$ & eritema infeccioso & soro & 16.06.99 & Belém & + & 0.933 & + & 1.657 & + & $\mathrm{B} 19$ \\
\hline 203 & 71.330 & $\mathrm{~F}$ & $22 \mathrm{a}$ & $5 d$ & artropatia aguda & soro & 17.06 .99 & Belém & + & 0.763 & - & 0.041 & - & \\
\hline
\end{tabular}




\begin{tabular}{|c|c|c|c|c|c|c|c|c|c|c|c|c|c|c|}
\hline & Registro & Sexo & Idade & $\begin{array}{l}\text { Tempo } \\
\text { doença }\end{array}$ & Quadro clínico & Espécime & Coleta & Local & & $\lg M$ & & $\lg G$ & PCR & $\begin{array}{c}\text { nuaçã } \\
\text { Seq. }\end{array}$ \\
\hline 204 & 71.334 & $\mathrm{~F}$ & $10 a$ & $7 d$ & eritema infeccioso & soro & 18.06.99 & Belém & + & 0.368 & + & 1.635 & + & B19 \\
\hline 205 & 71.350 & $M$ & $6 a$ & $5 d$ & eritema infeccioso & soro & 21.06 .99 & Belém & + & 1.267 & - & 0.095 & - & \\
\hline 206 & 71.359 & $\mathrm{M}$ & $8 a$ & $6 d$ & eritema infeccioso & soro & 21.06 .99 & Belém & + & 0.889 & - & 0.058 & - & \\
\hline 207 & 71.391 & $\mathrm{~F}$ & $1 a$ & $14 d$ & anemia & soro & 23.06 .99 & Ananindeua & - & 0.059 & - & 0.115 & - & \\
\hline 208 & 71.532 & $\mathrm{M}$ & $31 a$ & $6 \mathrm{~d}$ & eritema infeccioso & soro & 02.07 .99 & Belém & + & 0.330 & - & 0.098 & - & \\
\hline 209 & 71.685 & $\mathrm{~F}$ & $19 a$ & $20 d$ & púrpura trombocitopênica & plasma & 14.07 .99 & Ananindeua & + & 0.529 & + & 1.166 & - & \\
\hline 210 & 71.701 & $\mathrm{M}$ & $5 a$ & $7 d$ & eritema infeccioso & soro & 15.07 .99 & Belém & + & 0.351 & - & 0.112 & - & \\
\hline 211 & 71.716 & $\mathrm{M}$ & $4 a$ & $8 d$ & eritema infeccioso & soro & 16.07 .99 & Belém & + & 1.425 & + & 1.600 & - & \\
\hline 212 & 71.805 & $\mathrm{~F}$ & $29 a$ & $8 d$ & artropatia aguda & soro & 29.07 .99 & Belém & + & 1.064 & + & 1.469 & + & $\mathrm{B} 19$ \\
\hline 213 & 71.897 & $\mathrm{~F}$ & $24 a$ & $9 d$ & artropatia aguda & soro & 09.08 .99 & Benevides & + & 0.501 & + & 0.357 & - & \\
\hline 214 & 71.913 & $\mathrm{~F}$ & $3 a$ & $10 d$ & eritema infeccioso & soro & 10.08.99 & Benevides & + & 0.506 & + & 0.945 & - & \\
\hline 215 & 71.915 & $\mathrm{M}$ & $51 \mathrm{a}$ & $8 d$ & artropatia aguda & soro & 10.08.99 & Belém & + & 0.339 & + & 0.705 & - & \\
\hline 216 & 71.934 & $\mathrm{~F}$ & $1 \mathrm{a}$ & $7 d$ & eritema infeccioso & soro & 11.08 .99 & Ananindeua & + & 1.385 & + & 1.470 & + & B19 \\
\hline 217 & 71.981 & $\mathrm{~F}$ & $11 \mathrm{a}$ & $6 d$ & eritema infeccioso & soro & 16.08.99 & Outeiro & + & 0.732 & + & 1.647 & - & \\
\hline 218 & 71.988 & $\mathrm{~F}$ & $17 \mathrm{a}$ & $6 d$ & artropatia aguda & soro & 16.08 .99 & Belém & + & 0.603 & + & 1.562 & - & \\
\hline 219 & 72.037 & $\mathrm{M}$ & $18 a$ & $8 d$ & artropatia aguda & soro & 23.08 .99 & Belém & + & 0.536 & + & 1.437 & - & \\
\hline 220 & 72.129 & $\mathrm{M}$ & $3 a$ & $10 d$ & anemia crônica & soro & 31.08 .99 & Belém & + & 1.422 & - & 0.135 & - & \\
\hline 221 & 72.253 & $\mathrm{M}$ & $5 a$ & $5 d$ & eritema infeccioso & soro & 13.09 .99 & Belém & + & 0.324 & + & 1.328 & - & \\
\hline 222 & 72.258 & $\mathrm{M}$ & $36 a$ & $9 d$ & eritema infeccioso & soro & 13.09.99 & Ananindeua & + & 0.375 & + & 1.564 & - & \\
\hline 223 & 72.346 & $\mathrm{M}$ & $11 \mathrm{a}$ & $7 d$ & eritema infeccioso & soro & 21.09 .99 & Belém & + & 0.750 & - & 0.073 & + & $\mathrm{B} 19$ \\
\hline 224 & 72.683 & $\mathrm{~F}$ & $9 a$ & $8 d$ & Artropatia acuda & soro & 20.10 .99 & Belém & + & 2.586 & - & 0.128 & + & B19 \\
\hline 225 & 72.697 & $\mathrm{~F}$ & $1 \mathrm{a}$ & $7 d$ & febre, anemia & soro & 21.10 .99 & Belém & + & 0.364 & - & 0.115 & + & $\mathrm{B} 19$ \\
\hline 226 & 72.779 & $\mathrm{~F}$ & $5 a$ & $7 d$ & eritema infeccioso & soro & 28.10 .99 & Ananindeua & + & 0.340 & + & 1.498 & - & \\
\hline 227 & 72.824 & $\mathrm{M}$ & $7 a$ & $7 d$ & eritema infeccioso & soro & 04.11 .99 & Belém & + & 2.459 & + & 1.270 & + & $\mathrm{B} 19$ \\
\hline 228 & 72.882 & $\mathrm{~F}$ & $14 a$ & $6 d$ & febre, lupus eritematoso sistêmico & soro & 09.11 .99 & SantaBárbara & + & 0.404 & - & 0.056 & + & $\mathrm{D}-91$ \\
\hline 229 & 73.208 & $\mathrm{M}$ & $5 a$ & $8 d$ & eritema infeccioso & soro & 02.12 .99 & Belém & + & 1.479 & + & 1.655 & + & $\mathrm{B} 19$ \\
\hline
\end{tabular}




\begin{tabular}{|c|c|c|c|c|c|c|c|c|c|c|c|c|c|c|}
\hline & Registro & Sexo & Idade & $\begin{array}{l}\text { Tempo } \\
\text { doença }\end{array}$ & Quadro clínico & Espécime & Coleta & Local & & $\lg M$ & & $\lg G$ & PCR & Seq. \\
\hline 230 & 73.209 & $\mathrm{~F}$ & $17 \mathrm{a}$ & $15 d$ & artropatia aguda & soro & 31.11 .99 & Belém & - & 0.094 & + & 1.369 & - & \\
\hline 231 & 73.324 & $\mathrm{~F}$ & $49 a$ & $6 d$ & febre,lupus eritematoso sistêmico & plasma & 13.12 .99 & Belém & - & 0.131 & + & 0.430 & - & \\
\hline 232 & 73.447 & $\mathrm{~F}$ & $47 a$ & $8 d$ & artropatia aguda & soro & 28.10 .99 & Marituba & - & 0.113 & + & 1.482 & - & \\
\hline 233 & 73.449 & M & $7 a$ & $6 \mathrm{~d}$ & eritema infeccioso & soro & 28.12 .99 & Belém & + & 0.770 & - & 0.074 & - & \\
\hline 234 & 73.549 & $M$ & $3 m$ & $9 d$ & anemia & soro & 07.01 .00 & Belém & - & 0.079 & - & 0.123 & - & \\
\hline 235 & 73.656 & $M$ & $60 a$ & $8 d$ & eritema infeccioso & soro & 18.01 .00 & Ananindeua & + & 0.581 & - & 0.130 & - & \\
\hline 236 & 73.666 & $\mathrm{~F}$ & $28 \mathrm{a}$ & $8 d$ & artropatia aguda & soro & 19.01 .00 & Belém & - & 0.072 & + & 2.139 & - & \\
\hline 237 & 73.714 & $\mathrm{M}$ & $16 a$ & $10 d$ & artropatia aguda & soro & 24.01 .00 & Belém & - & 0.063 & + & 1.422 & - & \\
\hline 238 & 73.718 & $\mathrm{~F}$ & $6 a$ & $8 d$ & artropatia aguda & soro & 24.01 .00 & Belém & - & 0.070 & + & 1.074 & - & \\
\hline 239 & 73.815 & $\mathrm{M}$ & $5 a$ & $8 d$ & eritema infeccioso & soro & 01.02 .00 & Belém & - & 0.141 & + & 1.761 & - & \\
\hline 240 & 73.878 & $\mathrm{~F}$ & $11 \mathrm{a}$ & $15 d$ & púrpura trombocitopênica & soro & 08.02 .00 & Belém & - & 0.122 & + & 0.424 & - & \\
\hline 241 & 73.889 & $\mathrm{~F}$ & $10 a$ & $6 \mathrm{~d}$ & eritema infeccioso & soro & 09.02 .00 & Belém & + & 1.098 & + & 1.523 & - & \\
\hline 242 & 73.928 & $\mathrm{~F}$ & $7 a$ & $7 d$ & eritema infeccioso & soro & 14.02 .00 & Ananindeua & + & 0.445 & + & 1.364 & - & \\
\hline 243 & 74.008 & $\mathrm{~F}$ & $28 a$ & $10 d$ & artropatia aguda & soro & 22.02 .00 & Belém & - & 0.078 & + & 3.404 & - & \\
\hline 244 & 74.069 & $\mathrm{~F}$ & $14 a$ & $18 d$ & febre, lupus eritematoso sistêmico & soro & 28.02 .00 & Belém & - & 0.123 & + & 1.615 & - & \\
\hline 245 & 74.092 & $\mathrm{~F}$ & $28 a$ & $12 d$ & artropatia aguda & soro & 01.03 .00 & Belém & - & 0.126 & + & 3.506 & - & \\
\hline 246 & 74.220 & $\mathrm{~F}$ & $41 \mathrm{a}$ & $16 d$ & púrpura trombocitopênica & soro & 16.03 .00 & Ananindeua & - & 0.144 & + & 0.746 & - & \\
\hline 247 & 74.489 & $\mathrm{~F}$ & $11 \mathrm{a}$ & $10 d$ & anemia crônica & soro & 13.04 .00 & Belém & - & 0.151 & - & 0.129 & - & \\
\hline 248 & 74.633 & $\mathrm{~F}$ & $38 \mathrm{a}$ & $7 d$ & eritema infeccioso & soro & 04.05 .00 & Belém & + & 2.388 & - & 0.081 & + & B19 \\
\hline 249 & 74.675 & $\mathrm{~F}$ & $9 a$ & $7 d$ & eritema infeccioso & soro & 11.05 .00 & Belém & + & 1.501 & + & 1.503 & + & D-91 \\
\hline 250 & 74.712 & $\mathrm{~F}$ & $8 a$ & $10 d$ & anemia hemolitica crônica & soro & 18.05 .00 & Belém & - & 0.097 & + & 1.358 & - & \\
\hline 251 & 74.870 & M & $13 a$ & $8 d$ & eritema infeccioso & soro & 07.06 .00 & Belém & + & 1.952 & + & 1.158 & + & D-91 \\
\hline 252 & 74.919 & $\mathrm{~F}$ & $8 a$ & $6 \mathrm{~d}$ & eritema infeccioso & soro & 14.06 .00 & Belém & + & 0.828 & + & 1.469 & + & B19 \\
\hline 253 & 74.972 & $\mathrm{~F}$ & $27 a$ & $8 d$ & artropatia aguda & soro & 21.06 .00 & Belém & - & 0.084 & + & 1.577 & - & \\
\hline 254 & 74.999 & $\mathrm{M}$ & $1 \mathrm{a}$ & $7 d$ & eritema infeccioso & soro & 26.06 .00 & Belém & + & 1.249 & + & 0.506 & + & B19 \\
\hline 255 & 75.057 & $\mathrm{~F}$ & $10 \mathrm{~m}$ & $10 d$ & eritema infeccioso & soro & 30.06 .00 & Belém & + & 2.189 & + & 1.334 & + & B19 \\
\hline
\end{tabular}




\begin{tabular}{|c|c|c|c|c|c|c|c|c|c|c|c|c|c|c|}
\hline & Registro & Sexo & Idade & $\begin{array}{l}\text { Tempo } \\
\text { doença }\end{array}$ & Quadro clínico & Espécime & Coleta & Local & & $\lg M$ & & $\lg G$ & $\begin{array}{l}\text { (cont } \\
\text { PCR }\end{array}$ & $\begin{array}{l}\text { nuaçã } \\
\text { Seq. }\end{array}$ \\
\hline 256 & 75.060 & $\mathrm{~F}$ & $3 a$ & $7 d$ & eritema infeccioso & soro & 03.07 .00 & Belém & + & 2.631 & + & 0.980 & + & B19 \\
\hline 257 & 75.229 & $\mathrm{~F}$ & $13 a$ & $8 d$ & artropatia aguda & soro & 31.07 .00 & Belém & + & 0.653 & + & 1.427 & + & $\mathrm{D}-91$ \\
\hline 258 & 75.230 & $\mathrm{~F}$ & $7 a$ & $7 d$ & eritema infeccioso & soro & 31.07 .00 & Belém & + & 0.705 & + & 1.342 & + & $\mathrm{D}-91$ \\
\hline 259 & 75.310 & $\mathrm{~F}$ & $8 a$ & $10 d$ & púrpura trombocitopênica & soro & 11.08 .00 & Belém & - & 0.149 & - & 0.051 & - & \\
\hline 260 & 75.374 & $\mathrm{~F}$ & $5 a$ & $8 d$ & artropatia aguda & soro & 23.08 .00 & Ananindeua & - & 0.061 & + & 3.353 & - & \\
\hline 261 & 75.559 & $\mathrm{M}$ & $7 a$ & $7 d$ & eritema infeccioso & soro & 15.09 .00 & Belém & + & 0.565 & + & 1.522 & + & D-91 \\
\hline 262 & 75.695 & $\mathrm{~F}$ & $19 a$ & $5 d$ & artropatia aguda & soro & 29.09 .00 & Ananindeua & - & 0.129 & + & 3.993 & - & \\
\hline 263 & 75.757 & $\mathrm{~F}$ & $8 a$ & $12 d$ & púrpura trombocitopênica & plasma & 05.10 .00 & Belém & - & 0.164 & + & 0.700 & - & \\
\hline 264 & 75.770 & $\mathrm{M}$ & $2 a$ & $8 d$ & febre, anemia & soro & 06.10 .00 & Belém & + & 0.336 & - & 0.071 & - & \\
\hline 265 & 75.773 & $\mathrm{~F}$ & $10 a$ & $8 d$ & eritema infeccioso & soro & 06.10 .00 & Belém & + & 0.656 & + & 1.706 & + & $\mathrm{B} 19$ \\
\hline 266 & 75.775 & $\mathrm{M}$ & $1 a$ & $6 d$ & eritema infeccios o & soro & 06.10 .00 & Belém & + & 1.111 & + & 0.765 & + & $\mathrm{B} 19$ \\
\hline 267 & 75.844 & $\mathrm{M}$ & $2 a$ & $7 d$ & eritema infeccioso & soro & 10.10.00 & Belém & + & 0.384 & + & 1.390 & + & B19 \\
\hline 268 & 75.856 & $\mathrm{~F}$ & $7 a$ & $7 d$ & eritema infeccioso & soro & 11.10 .00 & Belém & + & 0.567 & + & 1.158 & - & \\
\hline 269 & 75.857 & $\mathrm{~F}$ & $25 a$ & $6 \mathrm{~d}$ & eritema infeccioso & soro & 11.10 .00 & Belém & + & 0.489 & + & 1.110 & - & \\
\hline 270 & 75.883 & $\mathrm{~F}$ & $26 a$ & $9 d$ & eritema infeccioso & soro & 17.10 .00 & Ananindeua & + & 1.651 & + & 1.548 & + & B19 \\
\hline 271 & 75.894 & $\mathrm{M}$ & $15 a$ & $8 d$ & eritema infeccioso & soro & 18.10 .00 & Belém & + & 0.896 & + & 1.421 & - & \\
\hline 272 & 75.914 & $\mathrm{M}$ & $10 \mathrm{a}$ & $8 d$ & eritema infeccioso & soro & 19.10.00 & Santa Isabel & + & 0.563 & + & 1.321 & + & B19 \\
\hline 273 & 76.056 & $\mathrm{~F}$ & $3 a$ & $6 d$ & eritema infeccioso & soro & 13.11 .00 & Belém & + & 0.502 & + & 1.184 & + & B19 \\
\hline 274 & 76.071 & $\mathrm{M}$ & $7 a$ & $7 d$ & eritema infeccioso & soro & 14.11 .00 & Belém & + & 0.450 & + & 1.724 & + & $\mathrm{B} 19$ \\
\hline 275 & 76.218 & $\mathrm{~F}$ & $9 a$ & $8 d$ & eritema infeccioso & soro & 23.11 .00 & Belém & + & 0.565 & + & 1.386 & + & B19 \\
\hline 276 & 76.352 & $\mathrm{~F}$ & $36 a$ & $10 d$ & artropatia aguda & soro & 04.12 .00 & Ananindeua & - & 0.102 & + & 3.597 & - & \\
\hline 277 & 76.360 & $\mathrm{~F}$ & $12 \mathrm{a}$ & $10 d$ & artropatia aguda & soro & 04.12 .00 & Belém & - & 0.118 & + & 1.447 & - & \\
\hline 278 & 76.452 & $\mathrm{M}$ & $33 a$ & $7 d$ & artropatia aguda & soro & 11.12 .00 & Belém & - & 0.070 & + & 3.349 & - & \\
\hline 279 & 76.525 & $\mathrm{~F}$ & $7 a$ & $6 d$ & eritema infeccioso & soro & 15.12 .00 & Ananindeua & + & 0.635 & + & 1.387 & + & B19 \\
\hline 280 & 76.566 & $\mathrm{~F}$ & $18 a$ & $15 d$ & artropatia aguda & soro & 20.12 .00 & Belém & - & 0.105 & + & 3.670 & - & \\
\hline 281 & 76.598 & $\mathrm{~F}$ & $44 a$ & $10 d$ & eritema infeccioso & soro & 26.12 .00 & Ananindeua & - & 0.151 & + & 3.592 & - & \\
\hline
\end{tabular}




\begin{tabular}{|c|c|c|c|c|c|c|c|c|c|c|c|c|c|c|}
\hline & Registro & Sexo & Idade & $\begin{array}{l}\text { Tempo } \\
\text { doença }\end{array}$ & Quadro clínico & Espécime & Coleta & Local & & $\lg M$ & & $\lg G$ & $\begin{array}{l}\text { (cont } \\
\text { PCR }\end{array}$ & $\begin{array}{l}\text { nuaçã } \\
\text { Seq. }\end{array}$ \\
\hline 282 & 76.599 & $\mathrm{~F}$ & $28 a$ & $8 d$ & artropatia aguda & soro & 26.12 .00 & Marituba & - & 0.147 & + & 3.458 & - & \\
\hline 283 & 76.622 & $\mathrm{M}$ & $10 a$ & $7 d$ & eritema infeccioso & soro & 29.12.00 & Belém & + & 0.543 & + & 0.896 & + & B19 \\
\hline 284 & 76.820 & $\mathrm{~F}$ & $11 \mathrm{~m}$ & $6 \mathrm{~d}$ & eritema infeccioso & soro & 15.01 .01 & Belém & + & 0.412 & - & 0.133 & - & \\
\hline 285 & 76.845 & $\mathrm{M}$ & $9 a$ & $6 d$ & eritema infeccioso & soro & 18.01 .01 & Belém & + & 1.051 & + & 1.779 & - & \\
\hline 286 & 77.007 & $\mathrm{M}$ & $5 a$ & $7 d$ & eritema infeccioso & soro & 12.02 .01 & Belém & + & 0.473 & + & 1.621 & + & $\mathrm{B} 19$ \\
\hline 287 & 77.052 & $\mathrm{M}$ & $12 a$ & $9 d$ & plaquetopenia & soro & 16.02 .01 & Ananindeua & + & 0.340 & + & 1.762 & - & \\
\hline 288 & 77.522 & $\mathrm{~F}$ & $17 a$ & $6 d$ & eritema infeccioso & soro & 14.03 .01 & Belém & + & 1.304 & + & 1.743 & + & $\mathrm{B} 19$ \\
\hline 289 & 77.740 & $\mathrm{~F}$ & $10 a$ & $8 d$ & eritema infeccioso & soro & 06.04 .01 & Ananindeua & + & 2.138 & + & 1.318 & + & $\mathrm{B} 19$ \\
\hline 290 & 77.750 & $\mathrm{~F}$ & $11 \mathrm{a}$ & $10 \mathrm{~d}$ & febre, anemia falciforme & soro & 28.03 .01 & Belém & + & 1.791 & + & 0.750 & + & $\mathrm{B} 19$ \\
\hline 291 & 77.923 & $\mathrm{M}$ & $23 a$ & $7 d$ & eritema infeccioso & soro & 02.05 .01 & Belém & + & 1.752 & + & 1.844 & + & $\mathrm{B} 19$ \\
\hline 292 & 78.050 & $\mathrm{~F}$ & $5 a$ & $10 \mathrm{~d}$ & eritema infeccioso & soro & 17.05 .01 & Ananindeua & + & 2.156 & + & 1.165 & + & B19 \\
\hline 293 & 78.126 & $\mathrm{~F}$ & $5 a$ & $5 d$ & eritema infeccioso & soro & 25.05 .01 & Belém & - & 0.118 & + & 0.942 & - & \\
\hline 294 & 78.171 & $\mathrm{~F}$ & $1 \mathrm{a}$ & $8 d$ & eritema infeccioso & soro & 30.05 .01 & Belém & + & 3.324 & + & 0.886 & + & $\mathrm{B} 19$ \\
\hline 295 & 78.321 & $\mathrm{~F}$ & $5 a$ & $5 d$ & eritema infeccioso & soro & 18.06.01 & Belém & + & 1.706 & + & 1.360 & + & B19 \\
\hline 296 & 78.422 & $\mathrm{~F}$ & 18 & $8 d$ & plaquetopenia & plasma & 27.06 .01 & Belém & + & 1.316 & + & 1.272 & + & $\mathrm{B} 19$ \\
\hline 297 & 78.472 & $\mathrm{~F}$ & $10 \mathrm{a}$ & $8 d$ & eritema infeccioso & soro & 02.07.01 & Belém & + & 3.140 & - & 0.198 & + & $\mathrm{B} 19$ \\
\hline 298 & 78.688 & $\mathrm{~F}$ & $2 a$ & $14 d$ & púrpura trombocitopênica & soro & 02.08 .01 & Belém & + & 0.429 & + & 0.875 & - & \\
\hline 299 & 78.808 & $\mathrm{M}$ & $7 \mathrm{~m}$ & $7 d$ & eritema infeccioso & soro & 20.08 .01 & Belém & + & 0.349 & + & 0.421 & - & \\
\hline 300 & 78.815 & $\mathrm{~F}$ & $30 a$ & $8 d$ & eritema infeccioso & soro & 17.08 .01 & Belém & + & 3.289 & + & 1.582 & + & $\mathrm{B} 19$ \\
\hline 301 & 78.837 & $\mathrm{~F}$ & $3 m$ & $10 d$ & anemia hemolitica crônica & soro & 21.08 .01 & Belém & + & 0.788 & + & 1.476 & - & \\
\hline 302 & 79.055 & $\mathrm{~F}$ & $37 a$ & $7 d$ & artropatia aguda & soro & 17.09 .01 & Belém & + & 1.800 & + & 0.534 & + & $\mathrm{B} 19$ \\
\hline 303 & 79.057 & $\mathrm{~F}$ & $1 a$ & $14 d$ & púrpura trombocitopênica & soro & 10.09 .01 & Belém & - & 0.076 & - & 0.047 & - & \\
\hline 304 & 79.066 & $\mathrm{~F}$ & $10 \mathrm{a}$ & $10 d$ & púrpura trombocitopênica & soro & 14.09 .01 & Belém & - & 0.217 & - & 0.002 & - & \\
\hline 305 & 79.097 & $\mathrm{M}$ & $4 a$ & $5 d$ & febre,anemia & soro & 26.09 .01 & Belém & + & 0.491 & - & 0.112 & - & \\
\hline 306 & 79.163 & $\mathrm{~F}$ & $28 \mathrm{a}$ & $7 d$ & artropatia aguda & soro & 04.10 .01 & Belém & + & 2.352 & + & 0.439 & + & $\mathrm{B} 19$ \\
\hline 307 & 79.238 & $\mathrm{M}$ & $2 a$ & $10 d$ & febre, hepatite & soro & 16.10.01 & Marituba & + & 0.528 & - & 0.067 & - & \\
\hline
\end{tabular}




\begin{tabular}{|c|c|c|c|c|c|c|c|c|c|c|c|c|c|c|}
\hline & Registro & Sexo & Idade & $\begin{array}{l}\text { Tempo } \\
\text { doença }\end{array}$ & Quadro clínico & Espécime & Coleta & Local & & $\lg M$ & & $\lg G$ & $\begin{array}{l}\text { (cont } \\
\text { PCR }\end{array}$ & Seq. \\
\hline 308 & 79.390 & M & $1 a$ & $10 d$ & anemia & soro & 06.11 .01 & Belém & - & 0.038 & - & 0.080 & - & \\
\hline 309 & 79.476 & $\mathrm{M}$ & $2 a$ & $12 d$ & anemia crônica & soro & 19.11.01 & Belém & - & 0.090 & - & 0.086 & - & \\
\hline 310 & 79.486 & $\mathrm{M}$ & $1 \mathrm{a}$ & $9 d$ & anemia & soro & 21.11 .01 & Abaetetuba & - & 0.029 & - & 0.069 & - & \\
\hline 311 & 79.521 & $\mathrm{M}$ & $2 a$ & $10 d$ & anemia hemolitica crônica & soro & 28.11 .01 & Belém & + & 0.322 & - & 0.116 & - & \\
\hline 312 & 79.572 & $\mathrm{~F}$ & $2 a$ & $11 d$ & febre, plaquetopenia & soro & 05.12 .01 & Belém & - & 0.137 & - & 0.060 & - & \\
\hline 313 & 79.634 & $\mathrm{M}$ & $2 a$ & $12 d$ & anemia crônica & soro & 14.12.01 & Belém & + & 0.383 & + & 0.883 & - & \\
\hline 314 & 79.662 & $\mathrm{M}$ & $6 a$ & $7 d$ & artropatia aguda & soro & 19.12.01 & Belém & + & 0.806 & + & 0.125 & - & \\
\hline 315 & 79.665 & $\mathrm{M}$ & $8 a$ & $15 d$ & anemia & soro & 19.12.01 & Belém & + & 1.031 & + & 1.443 & - & \\
\hline 316 & 79.761 & $\mathrm{M}$ & $2 a$ & $15 d$ & febre, anemia crônica & soro & 07.01 .02 & Belém & - & 0.026 & - & 0.033 & - & \\
\hline 317 & 79.859 & $\mathrm{M}$ & $4 m$ & $14 d$ & febre, hepatite & soro & 14.01 .02 & Ananindeua & + & 0.847 & - & 0.081 & - & \\
\hline 318 & 79.873 & $\mathrm{~F}$ & $3 a$ & $10 d$ & anemia & soro & 16.01 .02 & Marituba & - & 0.137 & - & 0.090 & - & \\
\hline 319 & 79.930 & $\mathrm{M}$ & $2 a$ & $12 d$ & anemia crônica & soro & 16.01 .02 & Belém & - & 0.062 & + & 0.819 & - & \\
\hline 320 & 79.962 & $\mathrm{M}$ & $60 a$ & $20 d$ & hepatite & soro & 23.01 .02 & Belém & - & 0.090 & - & 0.186 & - & \\
\hline 321 & 79.969 & $\mathrm{~F}$ & $5 a$ & $7 d$ & eritema infeccioso & soro & 25.01 .02 & Belém & + & 0.405 & - & 0.023 & - & \\
\hline 322 & 80.215 & $\mathrm{~F}$ & $8 a$ & $10 d$ & plaquetopenia & soro & 26.02 .02 & Belém & - & 0.142 & - & 0.046 & - & \\
\hline 323 & 80.549 & $\mathrm{M}$ & $11 \mathrm{a}$ & $10 d$ & miocardite & soro & 29.03.02 & Belém & - & 0.092 & - & 0.110 & - & \\
\hline 324 & 80.809 & $\mathrm{M}$ & $12 \mathrm{a}$ & $10 \mathrm{~d}$ & febre, púrpura trombocitopênica & soro & 24.04 .02 & Belém & + & 0.372 & + & 0.536 & - & \\
\hline 325 & 80.910 & $\mathrm{M}$ & $3 m$ & $15 d$ & miocardiopatia & soro & 06.05 .02 & Belém & - & 0.069 & - & 0.075 & - & \\
\hline 326 & 81.193 & $\mathrm{~F}$ & $72 a$ & $12 d$ & anemia crônica & soro & 06.06 .02 & Belém & + & 2.689 & + & 0.064 & - & \\
\hline 327 & 81.337 & $\mathrm{~F}$ & $5 a$ & $14 \mathrm{~d}$ & febre, hepatite & soro & 12.06 .02 & Macapá & + & 0.563 & - & 0.145 & - & \\
\hline 328 & 81.686 & $\mathrm{M}$ & $23 a$ & $15 d$ & hipoplasia medular & soro & 22.08 .02 & Belém & - & 0.113 & - & 0.150 & - & \\
\hline 329 & 81.766 & $\mathrm{M}$ & $55 a$ & $10 d$ & hipoplasia medular & soro & 02.09 .02 & Belém & - & 0.147 & - & 0.159 & - & \\
\hline 330 & 82.046 & $\mathrm{~F}$ & $56 a$ & $8 d$ & febre, anemia hemolitica crônica & soro & 15.10 .02 & Belém & + & 1.153 & + & 0.876 & + & D-91 \\
\hline 331 & 82.051 & $\mathrm{~F}$ & $62 a$ & $9 d$ & artropatia aguda & soro & 15.10 .03 & Belém & - & 0.153 & - & 0.095 & - & \\
\hline 332 & 82.315 & $\mathrm{~F}$ & $22 a$ & $10 d$ & anemia & soro & 31.10 .02 & Belém & + & 0.422 & + & 0.631 & - & \\
\hline 333 & 82.441 & $\mathrm{~F}$ & $33 a$ & $8 d$ & eritema infeccioso & soro & 06.11 .02 & Belém & + & 1.070 & + & 1.380 & - & \\
\hline
\end{tabular}




\begin{tabular}{|c|c|c|c|c|c|c|c|c|c|c|c|c|c|c|}
\hline & Registro & Sexo & Idade & $\begin{array}{l}\text { Tempo } \\
\text { doença }\end{array}$ & Quadro clínico & Espécime & Coleta & Local & & $\lg M$ & & $\lg G$ & PCR & Seq. \\
\hline 334 & 82.447 & M & $15 a$ & $8 d$ & febre, hipoplasia medular & soro & 07.11 .02 & Primavera & + & 1.199 & + & 0.340 & + & B19 \\
\hline 335 & 82.664 & $\mathrm{~F}$ & $29 a$ & $20 d$ & miocardite & soro & 10.12 .03 & Belém & - & 0.079 & + & 1.355 & - & \\
\hline 336 & 82.690 & M & $47 a$ & $14 d$ & púrpura trombocitopênica & plasma & 12.12 .02 & Belém & - & 0.140 & - & 0.053 & - & \\
\hline 337 & 82.855 & $\mathrm{~F}$ & $54 a$ & $10 d$ & anemia & soro & 16.01 .03 & Belém & - & 0.012 & + & 1.187 & - & \\
\hline 338 & 83.027 & M & $72 a$ & $20 d$ & plaquetopenia & soro & 09.01 .03 & Belém & - & 0.027 & + & 3.215 & - & \\
\hline 339 & 83.066 & $\mathrm{M}$ & $50 a$ & $15 d$ & plaquetopenia & soro & 30.01 .03 & Santarém & - & 0.039 & + & 1.323 & - & \\
\hline 340 & 83.426 & $\mathrm{~F}$ & $6 a$ & $21 d$ & púrpura trombocitopênica & soro & 28.02 .03 & Tucurui & - & 0.005 & + & 3.638 & - & \\
\hline 341 & 83.444 & M & $8 a$ & $20 d$ & febre,anemia & soro & 10.03 .03 & Belém & - & 0.012 & + & 3.762 & - & \\
\hline 342 & 83.553 & $\mathrm{~F}$ & $6 a$ & $18 d$ & aplasia medular & soro & 24.03 .03 & Belém & - & 0.019 & + & 3.469 & - & \\
\hline 343 & 83.715 & $\mathrm{~F}$ & $44 a$ & $21 d$ & anemia & soro & 08.04 .03 & Belém & - & 0.020 & + & 3.048 & - & \\
\hline 344 & 83.780 & M & $1 \mathrm{a}$ & $5 d$ & febre, anemia & soro & 15.04 .03 & Belém & - & 0.156 & - & 0.072 & + & D-91 \\
\hline 345 & 84.006 & $\mathrm{M}$ & 10 & $12 d$ & anemia falciforme & soro & 06.05 .03 & Belém & - & 0.003 & + & 3.526 & - & \\
\hline 346 & 84.119 & M & 16 & $18 d$ & anemia & soro & 21.05 .03 & Belém & - & 0.019 & + & 3.258 & - & \\
\hline 347 & 84.166 & M & $2 \mathrm{~m}$ & $20 d$ & anemia falciforme & soro & 23.05 .03 & Belém & + & 0.467 & + & 1.165 & - & \\
\hline 348 & 84.188 & $\mathrm{M}$ & $1 \mathrm{a}$ & $20 d$ & anemia,hepatoesplenomegalia. & soro & 25.05 .03 & Almerim & - & 0.092 & - & 0.120 & - & \\
\hline 349 & 84.311 & $\mathrm{~F}$ & $19 a$ & $7 d$ & eritema infeccioso & soro & 02.06 .03 & Belém & + & 0.376 & + & 2.039 & + & B19 \\
\hline 350 & 84.361 & $\mathrm{~F}$ & $23 a$ & $15 d$ & anemia hemolítica crônica & soro & 17.06 .03 & Belém & - & 0.209 & + & 3.462 & - & \\
\hline 351 & 84.364 & M & $17 a$ & $20 d$ & anemia,hipoplasia medular & soro & 17.06 .03 & Belém & - & 0.052 & + & 2.133 & - & \\
\hline 352 & 84.382 & M & $44 a$ & $15 d$ & pancitopenia,mielodisplasia & soro & 18.06.03 & Belém & - & 0.039 & + & 3.894 & - & \\
\hline 353 & 84.411 & $\mathrm{~F}$ & $65 a$ & $10 \mathrm{~d}$ & hipoplasia medular & soro & 22.06 .03 & Belém & + & 0.326 & + & 4.036 & + & $\mathrm{B} 19$ \\
\hline 354 & 84.459 & $\mathrm{~F}$ & $55 a$ & $12 d$ & febre, lupus eritematoso sistêmico & soro & 27.06 .03 & Belém & - & 0.131 & - & 0.128 & - & \\
\hline 355 & 84.558 & $\mathrm{~F}$ & $47 a$ & $9 d$ & febre, anemia & soro & 11.07 .03 & Belém & + & 0.557 & + & 2.245 & + & B19 \\
\hline 356 & 84.620 & M & $26 \mathrm{a}$ & $12 d$ & aplasia medular & soro & 22.07 .03 & Belém & - & 0.017 & + & 2.939 & - & \\
\hline 357 & 84.766 & $\mathrm{~F}$ & $24 a$ & $10 \mathrm{~d}$ & plaquetopenia & soro & 24.07 .03 & Belém & - & 0.025 & + & 3.658 & - & \\
\hline 358 & 84.890 & $\mathrm{~F}$ & $9 m$ & $12 d$ & anemia & soro & 13.08 .03 & Belém & - & 0.004 & - & 0.071 & - & \\
\hline 359 & 85.105 & $\mathrm{~F}$ & $3 a$ & $5 d$ & eritema infeccioso & soro & 11.09 .03 & Belém & - & 0.215 & + & 0.325 & - & \\
\hline
\end{tabular}




\begin{tabular}{|c|c|c|c|c|c|c|c|c|c|c|c|c|c|c|}
\hline & Registro & Sexo & Idade & $\begin{array}{l}\text { Tempo } \\
\text { doença }\end{array}$ & Quadro clínico & Espécime & Coleta & Local & & $\lg M$ & & $\lg G$ & PCR & Seq. \\
\hline 360 & 85.130 & $\mathrm{~F}$ & $5 \mathrm{~m}$ & $9 d$ & eritema infeccioso & soro & 11.09 .03 & Belém & + & 1.018 & + & 0.760 & - & \\
\hline 361 & 85.147 & M & $79 a$ & $9 d$ & febre,anemia & soro & 16.09.03 & Benevides & - & 0.019 & + & 2.755 & - & \\
\hline 362 & 85.205 & $\mathrm{M}$ & $14 a$ & $12 d$ & hipoplasia medular & soro & 24.09 .03 & Belém & - & 0.015 & - & 0.025 & - & \\
\hline 363 & 85.272 & $\mathrm{~F}$ & $80 a$ & $13 d$ & anemia & soro & 03.10 .03 & Belém & - & 0.010 & + & 2.799 & - & \\
\hline 364 & 85.278 & $\mathrm{~F}$ & $44 a$ & $10 d$ & anemia & soro & 03.10 .03 & Ananindeua & - & 0.010 & + & 3.576 & - & \\
\hline 365 & 85.323 & $\mathrm{M}$ & $34 a$ & $14 d$ & febre, hepatite & soro & 10.10.03 & Belém & - & 0.086 & - & 0.168 & - & \\
\hline 366 & 85.340 & M & $57 a$ & $15 d$ & hipoplasia medular & soro & 13.10 .03 & Belém & - & 0.040 & + & 3.880 & - & \\
\hline 367 & 85.382 & M & $16 a$ & $14 d$ & hipoplasia medular & soro & 17.10 .03 & Belém & - & 0.003 & + & 3.594 & - & \\
\hline 368 & 85.409 & $\mathrm{~F}$ & $2 \mathrm{~m}$ & $13 d$ & hipoplasia medular & soro & 21.10 .03 & Igarapé-Miri & - & 0.007 & + & 3.612 & - & \\
\hline 369 & 85.487 & M & $3 a$ & $12 d$ & anemia aplástica,pancitopenia & soro & 03.11 .03 & Belém & - & 0.013 & + & 3.246 & - & \\
\hline 370 & 85.555 & $\mathrm{~F}$ & $48 a$ & $10 \mathrm{~d}$ & anemia & soro & 11.11 .03 & Belém & - & 0.009 & + & 4.013 & - & \\
\hline 371 & 85.592 & M & 7 & $11 d$ & hipoplasia medular & soro & 13.11 .03 & Capanema & + & 0.452 & + & 0.385 & - & \\
\hline 372 & 85.622 & $\mathrm{~F}$ & $17 a$ & $10 d$ & anemia & soro & 17.11 .03 & Belém & - & 0.007 & + & 3.216 & - & \\
\hline 373 & 85.632 & $\mathrm{~F}$ & $26 a$ & $12 d$ & púrpura trombocitopênica & soro & 19.11 .03 & Mosqueiro & - & 0.024 & + & 3.270 & - & \\
\hline 374 & 85.884 & $\mathrm{~F}$ & $58 a$ & $15 d$ & hipoplasia medular & soro & 12.12 .03 & Belém & - & 0.007 & + & 3.102 & - & \\
\hline 375 & 85.914 & M & $27 a$ & $12 d$ & anemia & soro & 18.12.03 & Ananindeua & + & 0.443 & + & 3.280 & - & \\
\hline 376 & 86.011 & $\mathrm{~F}$ & $26 a$ & $10 \mathrm{~d}$ & púrpura trombocitopênica & soro & 07.01 .04 & Capanema & - & 0.024 & + & 3.468 & - & \\
\hline 377 & 86.040 & $\mathrm{~F}$ & $38 a$ & $15 d$ & sindrome mielodisplasica & soro & 09.01 .04 & Belém & - & 0.005 & + & 3.466 & - & \\
\hline 378 & 86.076 & $\mathrm{~F}$ & $8 m$ & $12 d$ & febre, hepatite & soro & 15.01 .04 & Belém & - & 0.151 & - & 0.060 & - & \\
\hline 379 & 86.080 & M & $1 \mathrm{a}$ & $12 d$ & febre, hepatite & soro & 15.01 .04 & Acará & - & 0.093 & - & 0.057 & - & \\
\hline 380 & 86.122 & $\mathrm{~F}$ & $66 a$ & $14 d$ & anemia, esferocitose congênita & soro & 21.01 .04 & Marituba & - & 0.122 & + & 2.136 & - & \\
\hline 381 & 86.127 & $\mathrm{~F}$ & $24 a$ & $14 d$ & aplasia medular & soro & 21.01 .04 & Belém & - & 0.007 & + & 3.668 & - & \\
\hline 382 & 86.213 & $\mathrm{~F}$ & $38 a$ & $9 d$ & eritema infeccioso & soro & 29.01 .04 & Belém & + & 0.372 & + & 0.699 & - & \\
\hline 383 & 86.277 & M & $4 \mathrm{~m}$ & $15 d$ & anemia & soro & 03.02 .04 & Belém & + & 0.554 & + & 0.481 & - & \\
\hline 384 & 86.286 & $\mathrm{~F}$ & $16 a$ & $12 d$ & anemia & soro & 04.02 .04 & Belém & - & 0.021 & + & 3.009 & - & \\
\hline 385 & 86.408 & $\mathrm{~F}$ & $40 a$ & $10 d$ & anemia & soro & 19.02.04 & Belém & - & 0.016 & + & 2.305 & - & \\
\hline
\end{tabular}




\begin{tabular}{|c|c|c|c|c|c|c|c|c|c|c|c|c|c|c|}
\hline & Registro & Sexo & Idade & $\begin{array}{l}\text { Tempo } \\
\text { doença }\end{array}$ & Quadro clínico & Espécime & Coleta & Local & & $\lg M$ & & $\lg G$ & $\begin{array}{l}\text { (cont } \\
\text { PCR }\end{array}$ & $\begin{array}{l}\text { nuaçá } \\
\text { Seq. }\end{array}$ \\
\hline 386 & 86.455 & $M$ & $7 a$ & $13 d$ & anemia falciforme & soro & 01.03 .04 & Belém & - & 0.035 & + & 3.584 & - & \\
\hline 387 & 86.467 & $\mathrm{M}$ & $43 a$ & $15 d$ & aplasia medular & soro & 03.03 .04 & Belém & - & 0.007 & + & 3.222 & - & \\
\hline 388 & 86.486 & $\mathrm{~F}$ & $32 a$ & $10 d$ & anemia & soro & 04.03 .04 & Belém & - & 0.039 & + & 3.526 & - & \\
\hline 389 & 86.649 & $\mathrm{M}$ & $5 a$ & $12 d$ & púrpura trombocitopênica & soro & 19.03 .04 & Marituba & - & 0.055 & + & 3.672 & - & \\
\hline 390 & 86.737 & $\mathrm{~F}$ & $36 a$ & $15 d$ & púrpura trombocitopênica & soro & 24.03 .04 & Ananindeua & - & 0.021 & + & 3.765 & - & \\
\hline 391 & 87.134 & $\mathrm{~F}$ & $46 a$ & $12 d$ & anemia crônica & soro & 26.04 .04 & Belém & - & 0.030 & + & 3.996 & - & \\
\hline 392 & 87.148 & $\mathrm{M}$ & $12 a$ & $11 d$ & anemia crônica & soro & 28.04 .04 & Belém & - & 0.041 & + & 2.821 & - & \\
\hline 393 & 87.188 & $\mathrm{M}$ & $10 a$ & $8 d$ & eritema infeccioso & soro & 05.05 .04 & Belém & + & 0.573 & + & 1.690 & - & \\
\hline 394 & 87.397 & M & $2 a$ & $12 d$ & anemia crônica & soro & 27.05 .04 & Ananindeua & - & 0.081 & - & 0.124 & - & \\
\hline 395 & 87.512 & $\mathrm{M}$ & $62 a$ & $15 d$ & hepatite & soro & 09.06 .04 & Paragominas & - & 0.113 & + & 2.681 & - & \\
\hline 396 & 87.769 & $\mathrm{~F}$ & $8 a$ & $16 d$ & púrpura trombocitopênica & soro & 29.06 .04 & Breves & - & 0.153 & - & 0.569 & - & \\
\hline 397 & 87.770 & $\mathrm{~F}$ & $6 a$ & $12 d$ & purpura trombocitopenica & soro & 29.06 .04 & Breves & + & 0.625 & + & 1.595 & - & \\
\hline 398 & 87.912 & $\mathrm{~F}$ & $11 \mathrm{a}$ & $10 \mathrm{~d}$ & púrpura trombocitopênica & soro & 14.07 .04 & Urianópolis & - & 0.144 & - & 0.135 & - & \\
\hline 399 & 87.958 & $\mathrm{M}$ & $2 a$ & $14 d$ & anemia crônica, plaquetopenia & soro & 22.07 .04 & Belém & - & 0.157 & - & 0.002 & - & \\
\hline 400 & 88.044 & $\mathrm{~F}$ & $10 a$ & $12 d$ & plaquetopenia & soro & 04.08 .04 & Belém & - & 0.049 & - & 0.049 & - & \\
\hline 401 & 88.137 & $\mathrm{~F}$ & $47 a$ & $7 d$ & artropatia aguda & soro & 18.08 .04 & Manaus & - & 0.142 & + & 3.347 & - & \\
\hline 402 & 88.169 & $\mathrm{~F}$ & $56 a$ & $10 \mathrm{~d}$ & aplasia medular,leucopenia & soro & 25.08 .04 & Castanhal & - & 0.150 & - & 0.124 & - & \\
\hline 403 & 88.263 & $\mathrm{~F}$ & $17 \mathrm{a}$ & $12 d$ & lupus eritematoso sistêmico & soro & 10.09 .04 & Belém & - & 0.068 & + & 2.374 & - & \\
\hline 404 & 88.577 & $\mathrm{~F}$ & $34 a$ & $15 d$ & aplasia medular & soro & 20.10 .04 & Macapá & + & 0.393 & - & 0.115 & - & \\
\hline 405 & 88.578 & $\mathrm{M}$ & $19 a$ & $13 d$ & púrpura trombocitopênica & soro & 20.10 .04 & Barcarena & - & 0.079 & - & 0.038 & - & \\
\hline 406 & 88.614 & M & $6 \mathrm{~m}$ & $15 d$ & anemia hemolitica crônica & soro & 22.10 .04 & Santa Isabel & - & 0.073 & - & 0.022 & - & \\
\hline 407 & 88.707. & $\mathrm{~F}$ & $51 a$ & $16 d$ & púrpura trombocitopênica & soro & 29.10 .04 & Belém & - & 0.148 & - & 0.017 & - & \\
\hline 408 & 88.735 & $\mathrm{~F}$ & $79 a$ & $10 \mathrm{~d}$ & hipoplasia medular & soro & 29.10 .04 & Ananindeua & - & 0.093 & - & 0.018 & - & \\
\hline 409 & 88.774 & $\mathrm{~F}$ & $8 a$ & $12 d$ & plaquetopenia & soro & 05.11 .04 & Paragominas & - & 0.153 & - & 0.029 & - & \\
\hline 410 & 88.804 & $\mathrm{M}$ & $40 \mathrm{a}$ & $10 \mathrm{~d}$ & púrpura trombocitopênica & soro & 11.11 .04 & Belém & - & 0.102 & - & 0.069 & - & \\
\hline 411 & 88.990 & $\mathrm{~F}$ & $49 a$ & $14 d$ & púrpura trombocitopênica & soro & 17.11 .04 & Belém & - & 0.120 & - & 0.123 & - & \\
\hline
\end{tabular}




\begin{tabular}{|c|c|c|c|c|c|c|c|c|c|c|c|c|c|c|}
\hline & Registro & Sexo & Idade & $\begin{array}{l}\text { Tempo } \\
\text { doença }\end{array}$ & Quadro clínico & Espécime & Coleta & Local & & $\lg M$ & & $\lg G$ & PCR & Seq. \\
\hline 412 & 89.021 & $\mathrm{~F}$ & $64 a$ & $15 d$ & leucopenia,plaquetopenia & soro & 24.11 .04 & Ananindeua & + & 0.326 & + & 1.694 & - & \\
\hline 413 & 89.077 & $\mathrm{~F}$ & $1 \mathrm{a}$ & $10 d$ & anemia & soro & 01.12 .04 & Ananindeua & - & 0.152 & - & 0.095 & - & \\
\hline 414 & 89.088 & $\mathrm{~F}$ & $31 \mathrm{a}$ & $12 d$ & anemia crônica & soro & 03.12 .04 & Marituba & - & 0.157 & - & 0.187 & - & \\
\hline 415 & 89.311 & $\mathrm{~F}$ & $2 a$ & $10 d$ & púrpura trombocitopênica & soro & 20.12 .04 & Marabá & - & 0.151 & - & 0.035 & - & \\
\hline 416 & 89.322 & $\mathrm{~F}$ & $60 a$ & $9 d$ & febre, plaquetopenia & soro & 21.12 .04 & Belém & + & 0.306 & + & 1.086 & + & B19 \\
\hline 417 & 89.367 & $\mathrm{~F}$ & $26 a$ & $10 d$ & anemia & soro & 30.12 .04 & Belém & + & 0.345 & + & 0.336 & + & $\mathrm{B} 19$ \\
\hline 418 & 89.386 & $\mathrm{~F}$ & $2 m$ & $10 d$ & anemia & soro & 06.01 .05 & Santa Isabel & + & 0.667 & + & 0.446 & - & \\
\hline 419 & 89.399 & M & $4 a$ & $9 d$ & púrpura trombocitopênica & soro & 10.01 .05 & Ananindeua & - & 0.051 & - & 0.010 & - & \\
\hline 420 & 89.465 & $\mathrm{M}$ & $12 \mathrm{a}$ & $11 d$ & púrpura trombocitopênica & soro & 27.01 .05 & Ananindeua & - & 0.057 & - & 0.112 & - & \\
\hline 421 & 89.487 & $\mathrm{~F}$ & $51 \mathrm{a}$ & $10 d$ & hepatite, esplenomegalia & soro & 26.01 .05 & Monte Alegre & - & 0.063 & + & 1.818 & - & \\
\hline 422 & 89.545 & $\mathrm{~F}$ & $52 a$ & $15 d$ & plaquetopenia & soro & 16.02 .05 & Óbidos & - & 0.100 & - & 0.038 & - & \\
\hline 423 & 89.551 & $\mathrm{M}$ & $6 a$ & $15 d$ & púpura trombocitopênica & soro & 16.02 .05 & Marituba & - & 0.063 & - & 0.024 & - & \\
\hline 424 & 89.568 & $\mathrm{~F}$ & $64 a$ & $13 d$ & anemia hemolítica crônica & soro & 18.02 .05 & Ananindeua & - & 0.057 & - & 0.031 & - & \\
\hline 425 & 89.594 & $\mathrm{~F}$ & $37 a$ & $8 d$ & febre, pancitopenia & soro & 23.02 .05 & Amapá & + & 0.299 & - & 0.162 & + & $\mathrm{B} 19$ \\
\hline 426 & 89.602 & $\mathrm{~F}$ & $10 a$ & $5 d$ & eritema infeccioso & soro & 23.02 .05 & Nova Timboteua & - & 0.028 & - & 0.027 & - & \\
\hline 427 & 89.611 & $\mathrm{M}$ & $21 a$ & $10 d$ & febre, aplasia medular & soro & 24.02 .05 & Belém & - & 0.120 & - & 0.009 & - & \\
\hline 428 & 89.623 & $\mathrm{~F}$ & $5 a$ & $13 d$ & anemia hemolitica crônica & soro & 25.02 .05 & Castanhal & - & 0.080 & - & 0.003 & - & \\
\hline 429 & 89.672 & $\mathrm{M}$ & $2 a$ & $10 d$ & púrpura trombocitopênica & soro & 02.03 .05 & Marabá & - & 0.042 & - & 0.026 & - & \\
\hline 430 & 89.675 & $\mathrm{~F}$ & $27 a$ & $12 d$ & púrpura trombocipênica & soro & 02.03 .05 & Nova Ipixuna & - & 0.149 & - & 0.029 & - & \\
\hline 431 & 89.680 & M & $5 a$ & $11 d$ & púrpura trombocipênica & soro & 25.02 .05 & Belém & + & 0.305 & - & 0.059 & - & \\
\hline 432 & 89.711 & $\mathrm{~F}$ & $50 a$ & $10 d$ & anemia crônica, leucopenia & soro & 02.03 .05 & Castanhal & + & 0.160 & + & 1.862 & + & B19 \\
\hline 433 & 89.725 & $\mathrm{M}$ & $6 a$ & $10 d$ & febre, miocardite & soro & 07.03 .05 & Bragança & + & 1.039 & + & 0.254 & + & B19 \\
\hline 434 & 89.735 & $\mathrm{~F}$ & $5 a$ & $9 d$ & febre, anemia & soro & 10.03.05 & Belém & + & 0.649 & - & 0.031 & + & B19 \\
\hline 435 & 89.769 & $\mathrm{~F}$ & $28 a$ & $6 d$ & febre, hipoplasia medular & soro & 11.03 .05 & Ananindeua & + & 1.895 & - & 0.019 & + & B19 \\
\hline 436 & 89.792 & M & $5 \mathrm{~m}$ & $7 d$ & febre, plaquetopenia, leucopenia & soro & 16.03 .05 & Ananindeua & + & 0.878 & - & 0.033 & + & B19 \\
\hline 437 & 89.811 & $\mathrm{~F}$ & $36 a$ & $10 d$ & anemia hemolitica crônica & soro & 16.03 .05 & Ananindeua & + & 0.374 & + & 0.800 & + & $\mathrm{B} 19$ \\
\hline
\end{tabular}




\begin{tabular}{|c|c|c|c|c|c|c|c|c|c|c|c|c|c|c|}
\hline & Registro & Sexo & Idade & $\begin{array}{l}\text { Tempo } \\
\text { doença }\end{array}$ & Quadro clínico & Espécime & Coleta & Local & & $\lg M$ & & $\lg G$ & $\begin{array}{l}\text { (cont } \\
\text { PCR }\end{array}$ & Seq. \\
\hline 438 & 89.813 & $\mathrm{~F}$ & $35 a$ & $14 d$ & anemia, hepatoesplenomegalia & soro & 16.03 .05 & Marapanin & - & 0.046 & + & 0.774 & - & \\
\hline 439 & 89.963 & $\mathrm{M}$ & $31 a$ & $15 d$ & miocardite & soro & 04.04 .05 & Belém & + & 0.427 & - & 0.112 & - & \\
\hline 440 & 89.968 & $\mathrm{~F}$ & $37 a$ & $10 d$ & anemia, leucopenia & soro & 16.03 .05 & Belém & - & 0.105 & - & 0.162 & - & \\
\hline 441 & 90.006 & $\mathrm{M}$ & $3 a$ & $14 d$ & púrpura trombocitopênica & soro & 06.04 .05 & Belém & + & 0.564 & + & 0.893 & - & \\
\hline 442 & 90.112 & $\mathrm{~F}$ & $25 a$ & $10 \mathrm{~d}$ & anemia & plasma & 18.04 .05 & Belém & - & 0.046 & - & 0.153 & - & \\
\hline 443 & 90.135 & $\mathrm{M}$ & $6 a$ & $13 d$ & anemia crônica & soro & 20.04 .05 & Belém & - & 0.096 & - & 0.071 & - & \\
\hline 444 & 90.142 & $\mathrm{~F}$ & $73 a$ & $14 d$ & anemia crônica & soro & 20.04 .05 & Belém & - & 0.111 & - & 0.165 & - & \\
\hline 445 & 90.149 & $\mathrm{~F}$ & $36 a$ & $15 d$ & lupus eritematoso sistêmico & soro & 25.04 .05 & Belém & - & 0.086 & + & 1.361 & - & \\
\hline 446 & 90.261 & $\mathrm{~F}$ & $5 a$ & $14 d$ & miocardite & soro & 10.05 .05 & Belém & - & 0.108 & - & 0.101 & - & \\
\hline 447 & 90.328 & $\mathrm{~F}$ & $42 \mathrm{a}$ & $9 d$ & artropatia aguda & soro & 16.05 .05 & Belém & + & 0.376 & + & 0.635 & - & \\
\hline 448 & 90.492 & $\mathrm{~F}$ & $3 a$ & $8 d$ & febre, aplasia medular & soro & 08.06 .05 & Belém & + & 1.068 & + & 0.868 & + & B19 \\
\hline 449 & 90.493 & $\mathrm{M}$ & $16 a$ & $10 \mathrm{~d}$ & púrpura trombocitopênica & soro & 08.06 .05 & Belém & - & 0.141 & - & 0.086 & - & \\
\hline 450 & 90.519 & $\mathrm{~F}$ & $50 a$ & $10 d$ & pancitopenia aguda & soro & 10.06 .05 & Belém & + & 0.319 & + & 0.510 & - & \\
\hline 451 & 90.602 & $\mathrm{~F}$ & $56 a$ & $7 d$ & aplasia medular & soro & 21.06 .05 & Cametá & - & 0.210 & + & 0.328 & - & \\
\hline 452 & 90.622 & $\mathrm{M}$ & $24 a$ & $10 \mathrm{~d}$ & aplasia medular & soro & 21.06 .05 & Belém & + & 0.660 & + & 0.821 & - & \\
\hline 453 & 90.650 & M & $19 a$ & $15 d$ & hepatite, esplenomegalia & soro & 28.06 .05 & Santa Isabel & - & 0.028 & + & 0.918 & - & \\
\hline 454 & 90.713 & $\mathrm{~F}$ & $1 \mathrm{a}$ & $8 d$ & febre, púrpura trombocitopênica & soro & 06.07 .05 & Ananindeua & + & 0.349 & + & 0.292 & + & B19 \\
\hline 455 & 90.773 & $\mathrm{M}$ & $11 \mathrm{~m}$ & $10 d$ & pancitopenia & soro & 14.07 .05 & Belém & + & 0.947 & + & 1.057 & - & \\
\hline 456 & 90.790 & $\mathrm{~F}$ & $9 m$ & $9 d$ & eritema infeccioso & soro & 20.07 .05 & Belém & + & 0.839 & + & 0.290 & - & \\
\hline 457 & 90.802 & $\mathrm{~F}$ & $27 a$ & $6 d$ & púrpura trombocitopênica & soro & 26.07 .05 & Belém & - & 0.212 & + & 0.303 & - & \\
\hline 458 & 90.809 & $\mathrm{~F}$ & $39 a$ & $10 d$ & anemia, plaquetopenia & soro & 25.07 .05 & Belém & + & 0.545 & + & 1.311 & - & \\
\hline 459 & 90.812 & $\mathrm{~F}$ & $37 a$ & $10 d$ & aplasia medular & soro & 28.07 .05 & Alenquer & - & 0.249 & - & 0.152 & - & \\
\hline 460 & 90.821 & $\mathrm{~F}$ & $13 a$ & $8 d$ & artropatia aguda & soro & 28.07 .05 & Belém & + & 1.064 & + & 1.056 & + & B19 \\
\hline 461 & 91.018 & $\mathrm{M}$ & $51 \mathrm{a}$ & $10 d$ & febre, hipoplasia medular & soro & 24.08 .05 & Breves & + & 0.575 & + & 2.408 & + & $\mathrm{B} 19$ \\
\hline 462 & 91.023 & M & $49 a$ & $8 d$ & febre, anemia hemolitica crônica & soro & 24.08 .05 & Belém & + & 0.400 & + & 0.505 & + & $\mathrm{B} 19$ \\
\hline 463 & 91.031 & $\mathrm{~F}$ & $54 a$ & $10 d$ & anemia hemolitica crônica & soro & 24.08 .05 & Belém & + & 2.049 & - & 0.161 & - & \\
\hline
\end{tabular}




\begin{tabular}{|c|c|c|c|c|c|c|c|c|c|c|c|c|c|c|}
\hline & Registro & Sexo & Idade & $\begin{array}{l}\text { Tempo } \\
\text { doença }\end{array}$ & Quadro clínico & Espécime & Coleta & Local & & $\lg M$ & & IgG & PCR & Seq. \\
\hline 464 & 91.065 & $\mathrm{~F}$ & $7 a$ & $15 \mathrm{~d}$ & febre, anemia falciforme & soro & 30.08 .05 & Abaetetuba & + & 0.508 & + & 1.611 & - & \\
\hline 465 & 91.079 & $\mathrm{~F}$ & $48 a$ & $7 \mathrm{~d}$ & anemia, leucopenia & soro & 01.09 .05 & Belém & + & 0.451 & + & 0.492 & + & B19 \\
\hline 466 & 91.086 & $\mathrm{~F}$ & $52 a$ & $12 d$ & aplasia medular & soro & 01.09 .05 & Tomé-Açu & - & 0.160 & + & 0.980 & - & \\
\hline 467 & 91.154 & $\mathrm{~F}$ & $56 a$ & $14 d$ & hipoplasia medular & soro & 31.08 .05 & Acará & + & 0.549 & + & 0.694 & - & \\
\hline 468 & 91.164 & $\mathrm{~F}$ & $37 a$ & $8 d$ & febre, anemia & soro & 06.09 .05 & Belém & + & 0.385 & + & 1.146 & + & B19 \\
\hline 469 & 91.167 & $\mathrm{~F}$ & $48 a$ & $5 d$ & febre, anemia & soro & 06.09 .05 & Marabá & - & 0.170 & - & 0.074 & + & B19 \\
\hline 470 & 91.170 & $\mathrm{~F}$ & $19 a$ & $14 d$ & púrpura trombocitopênica & soro & 06.09 .05 & Capanema & + & 1.117 & + & 0.595 & - & \\
\hline 471 & 91.186 & $\mathrm{~F}$ & $1 \mathrm{a}$ & $8 d$ & eritema infeccioso & soro & 13.09 .05 & Belém & + & 0.455 & + & 0.349 & + & $\mathrm{B} 19$ \\
\hline 472 & 91.191 & $\mathrm{~F}$ & $3 a$ & $14 d$ & púrpura trombocitopênica & soro & 13.09 .05 & Bragança & - & 0.145 & + & 0.334 & - & \\
\hline 473 & 91.220 & $\mathrm{~F}$ & $3 a$ & $10 d$ & febre, anemia & soro & 14.09 .05 & Belém & + & 0.463 & - & 0.084 & - & \\
\hline 474 & 91.228 & $\mathrm{~F}$ & $18 a$ & $9 \mathrm{~d}$ & eritema infeccioso & soro & 14.09 .05 & Ananindeua & + & 1.387 & + & 2.093 & + & $\mathrm{B} 19$ \\
\hline 475 & 91.261 & $\mathrm{~F}$ & $13 a$ & $7 d$ & eritema infeccioso & soro & 11.09 .05 & Belém & + & 0.510 & - & 0.147 & - & \\
\hline 476 & 91.267 & $\mathrm{M}$ & $1 \mathrm{a}$ & $12 \mathrm{~d}$ & trombocitopenia & soro & 11.09 .05 & Belém & - & 0.156 & - & 0.057 & - & \\
\hline 477 & 91.277 & $\mathrm{M}$ & $20 a$ & $9 d$ & artropatia aguda & soro & 23.09 .05 & Belém & + & 0.417 & + & 2.162 & + & B19 \\
\hline 478 & 91.283 & $\mathrm{~F}$ & $1 \mathrm{a}$ & $14 d$ & púrpura trombocitopênica & soro & 21.09 .05 & Chaves & + & 0.421 & + & 0.383 & - & \\
\hline 479 & 91.305 & $\mathrm{~F}$ & $7 a$ & $9 \mathrm{~d}$ & pancitopenia & soro & 28.09 .05 & Ananindeua & + & 0.360 & + & 0.578 & + & B19 \\
\hline 480 & 91.364 & $\mathrm{~F}$ & $26 a$ & $10 \mathrm{~d}$ & hipoplasia medular & soro & 05.10 .05 & Parauapebas & + & 0.343 & + & 1.509 & + & B19 \\
\hline 481 & 91.366 & M & $8 a$ & $7 d$ & eritema infeccioso & soro & 05.10 .05 & Belém & - & 0.079 & - & 0.106 & - & \\
\hline 482 & 91.373 & $\mathrm{M}$ & $14 a$ & $8 d$ & eritema infeccioso & soro & 07.10 .05 & Belém & + & 0.433 & + & 1.563 & - & \\
\hline 483 & 91.389 & $\mathrm{~F}$ & $7 \mathrm{~m}$ & $7 d$ & eritema infeccioso & soro & 07.10 .05 & Ananindeua & + & 0.390 & - & 0.095 & + & B19 \\
\hline 484 & 91.618 & $\mathrm{~F}$ & $8 a$ & $14 d$ & miocardite & soro & 18.11 .05 & Belém & - & 0.009 & + & 0.345 & - & \\
\hline 485 & 91.783 & $\mathrm{~F}$ & $21 \mathrm{a}$ & $15 d$ & anemia hemolitica crônica & soro & 29.12 .05 & Belém & - & 0.080 & + & 0.224 & - & \\
\hline 486 & 91.849 & $\mathrm{~F}$ & $46 a$ & $10 d$ & anemia & soro & 27.12 .05 & Belém & - & 0.097 & + & 0.836 & - & \\
\hline 487 & 91.855 & $\mathrm{~F}$ & $36 a$ & $5 d$ & artropatia aguda & soro & 12.12 .05 & Manaus & + & 3.288 & - & 0.104 & + & B19 \\
\hline
\end{tabular}




\section{ANEXO 2:}

FREITAS, R. B.; DURIGON, E. L.; OLIVEIRA, D. S.; ROMANO, C. M.; FREITAS, M. R. C.; LINHARES, A. C.; MELO, F. L.; WALSHKELLER, L.; BARBOSA, M. L.; HUATUCO, E. M. M.; HOLMES, E. C.; ZANOTTO, P. M. A. The "pressure pan" evolution of human erythrovirus B19 in the Amazon, Brazil. Virology, v. 369, n. 2, p. 281-287, 2007. 


\title{
The "pressure pan" evolution of human erythrovirus B19 in the Amazon, Brazil
}

Ronaldo Barros de Freitas a , Edison Luiz Durigon ${ }^{\mathrm{b}}$, Darleise de Souza Oliveira ${ }^{\mathrm{a}}$, Camila Malta Romano ${ }^{c}$, Maria Rute Castro de Freitas ${ }^{\mathrm{a}}$, Alexandre da Costa Linhares ${ }^{\mathrm{a}}$, Fernando Lucas Melo $^{c}$, Lílian Walshkeller ${ }^{b}$, Maria Luisa Barbosa ${ }^{\mathrm{d}}$, Egma M. Mayta Huatuco ${ }^{\mathrm{e}}$, Edward C. Holmes ${ }^{\text {f }}$, Paolo Marinho de A. Zanotto ${ }^{\text {c,* }}$

a Seção de Virologia, Instituto Evandro Chagas, Secretaria de Vigilância em Saúde, Ministério da Saúde, Belém, Brazil

${ }^{\mathrm{b}}$ Laboratorio de Virologia Clinica, Departamento de Micobiologia, Instituto de Ciências Biomédicas - ICB II, Universidade de São Paulo USP, São Paulo - SP, Brazil

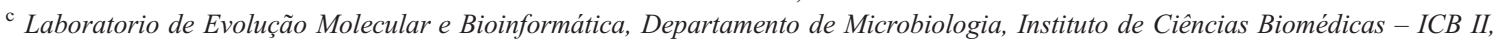
Universidade de São Paulo USP, São Paulo - SP, Brazil

${ }^{\mathrm{d}}$ Instituto Adolfo Lutz - São Paulo, Brazil

e University of San Marcos, Lima, Peru

${ }^{\mathrm{f}}$ Center for Infectious Disease Dynamics, Department of Biology, The Pennsylvania State University, Mueller Laboratory, University Park, PA 16802, USA

Received 23 March 2007; returned to author for revision 2 May 2007; accepted 3 July 2007

Available online 15 August 2007

\begin{abstract}
To understand the evolutionary dynamics of human parvovirus B19, we analyzed VP1 and VP2 gene sequences of B19 sampled from Belém (Amazon), the city of São Paulo, Brazil and globally. Our analysis revealed a strikingly different pattern of evolutionary change for those viral lineages introduced into Belém, which exhibited a higher rate of nonsynonymous substitutions compared to those viruses sampled from other locations. We propose that difference this is due to the high prevalence of B19 in Belém (up to 85\%) compared to other locations (prevalences of approximately 50\%), which imposes a more intense selection pressure. Hence, those B19 lineages introduced into Belém experienced an elevated rate of amino acid change, driven by positive selection, in order to generate serial re-infections in a small web of transmission, which can be thought of as an evolutionary "pressure pan".

(C) 2007 Elsevier Inc. All rights reserved.
\end{abstract}

Keywords: Erythrovirus evolution; Natural selection; B19 phylogeny

\section{Introduction}

A complex interplay of factors influences the emergence and re-emergence of viral diseases, including virus genetic variation (itself generated by mutation, recombination and reassortment) and environmental factors (ecological, social and behavioral influences). Most emerging diseases are caused by RNA viruses (Cleaveland et al., 2001), which can often quickly adapt to varying ecological conditions, including new host species, due

\footnotetext{
* Corresponding author.

E-mail address: pzanotto@usp.br (P.M.A. Zanotto).
}

to the high error rate of the virus RNA polymerase and their immense population sizes. In contrast, DNA viruses, which replicate by means of DNA polymerase, are less prone to mutational error, generally experience lower long-term rates of nucleotide substitution and, as a consequence, are less often associated with cross-species transmission.

However, not all DNA viruses evolve slowly. Most notably, canine parvovirus (CPV), a single-strand DNA virus, was recently found to possess an evolutionary rate of approximately $10^{-4}$ substitutions/site/year, broadly similar to that observed in RNA viruses, and to experience strong positive selection following its emergence from feline panleukopenia parvovirus (FPLV) or a closely related virus (Shackelton et al., 
2005). The erythrovirus B19, a human-associated member of the family Parvoviridae, evolves at a similar rate, suggesting that parvoviruses, and perhaps all single-stranded DNA viruses, experience an elevated mutation burden (Shackelton and Holmes, 2006). Parvovirus B19 is the only known human pathogenic erythrovirus and has been detected globally in human populations. The virus causes a wide spectrum of clinical conditions, mainly erythema infectious in children and arthropathy/arthralgia in adults. In immunocompetent individuals a self-limited infection is most common, while in immunocompromised patients a persistent infection may occur (Pattison, 1990; Brown et al., 1994). However, despite the clinical importance of B19 and the observation that it evolves at an elevated rate, little is known about the selection pressures acting on this virus and how they may differ among localities with differing epidemiological profiles. To this end, we conducted an intensive analysis of the evolutionary dynamics of genotype 1 of B19 in two populations in Brazil, i.e., Belém in the Amazon region and the metropolis of São Paulo.

\section{Results and discussion}

\section{Phylogenetic relationships of B19 virus}

In total, we obtained 46 individual sequences from 46 patients in Belém, sampled from 1995 to 2005, and 48 individual sequences from 48 patients from São Paulo, sampled from 1990 to 2003. These sequences were analyzed together with the reference sequences in a codon-based alignment of 139 taxa and covering $476 \mathrm{bp}$. The maximum a posteriori (MAP) tree for B19 with branch lengths corrected by time of isolation is shown in Fig. 1 (with the outgroup sequence removed to increase resolution). A similar topology was obtained using the ML method (data not shown). Although sequences from Belém (shown in magenta in Fig. 1) fall throughout the tree, most cluster into three

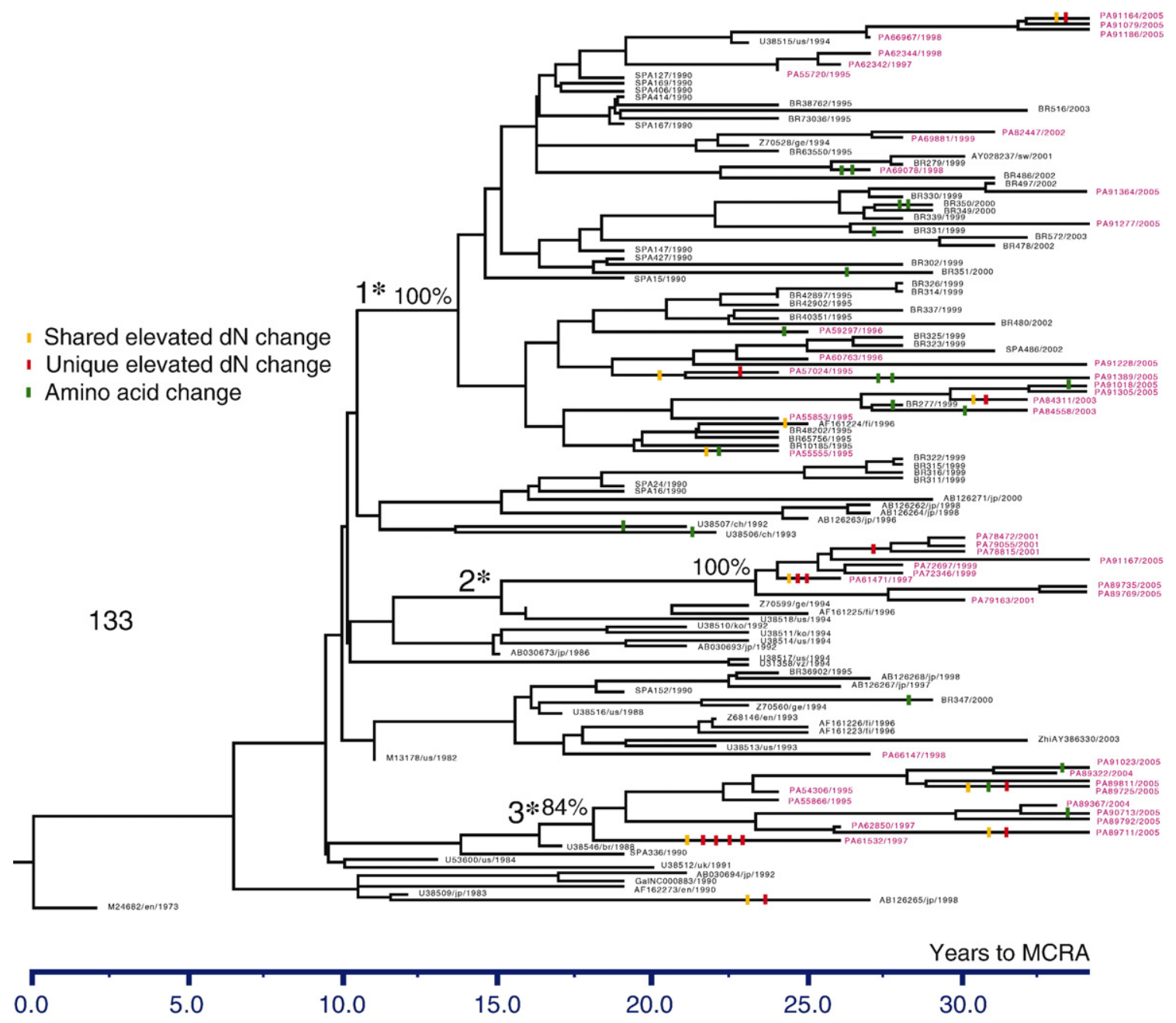

Fig. 1. Maximum a posteriori (MAP) tree for 133 sequences of the common region of VP1 and VP2 gene (477 bp) for human parvovirus B19. The tree has branch lengths set by date of sampling and a time-scale to a hypothetical Most Recent Common Ancestor (MRCA) before 1973. Three clusters of lineages including samples collected in Belém (Amazon) are shown by asterisks. Shared sites with elevated $d_{\mathrm{N}} / d_{\mathrm{S}}$ (yellow cross dashes), unique elevated $d_{\mathrm{N}} / d_{\mathrm{S}}$ ratios (red cross dashes) and amino acid changes taking place under purifying selection (green cross dashes), are shown along branches of the tree (i.e., lineages). 
main lineages (shown by numbers followed by the * symbol). Cluster $1^{*}$ was largely comprised of sequences from isolates from Brazil (including Belém) and suggested a significant exchange of viruses within Brazil, although it also contained 4 sequences sampled from elsewhere: a single US isolate from 1994 (U38515/US), a 2001 isolate from Sweden (AY028237/ sw), a 1994 isolate from Germany (Z70528/ge) and a 1996 isolate from Finland (AF161224/fi). In contrast, Clusters $2 *$ and $3^{*}$ are dominated by lineages from Belém and therefore appear to indicate independent introductions of lineages from the Northern hemisphere into Belém (although because of the relative small sampled size, we cannot exclude that the initial introduction was from southern Brazil). Nevertheless, both instances suggest the independent introduction of lineages of B19 genotype 1 into the Amazon region. To test for independent entries more formally, we compared the best tree for these data ( $\log$ likelihood $=-2721.907)$, to that obtained under a topological constraint that forces samples from Belém to become monophyletic (log likelihood $=-2758.270)$, which would imply a single introduction event. The difference in likelihood of 36.363 was significant with a one-tailed Shimoidara-Hasegawa test $(p=0.045)$, supporting the hypothesis of multiple and in- dependent introductions of genotype 1 lineages into the Amazon region.

\section{Patterns of evolutionary change}

Since the phylogenetic analysis suggested independent introductions of B19 virus into the Amazon, we divided the sequences into 2 groups - Belém and 'Cosmopolitan' (i.e., all sequences from elsewhere, including São Paulo) - to determine whether they differ in evolutionary dynamics. First, to obtain a graphical overview of the data, we explored patterns of genetic divergence at different codon positions. This revealed far higher genetic distances at the $1 \mathrm{st}$ and 2 nd codon positions of B19 isolates in Belém compared to the Cosmopolitan population, as indicated by the slopes of regressions in Fig. 2. In marked contrast, the 3rd codon positions of B19 isolates in Belém had lower levels of genetic divergence than that of the Cosmopolitan sequences (Fig. 2). This highly distinctive pattern indicates that B19 in Belém is characterized by a higher rate of nonsynonymous substitution than those viral isolates sampled from other locations, but that levels of genetic diversity at synonymous sites are consistently reduced.

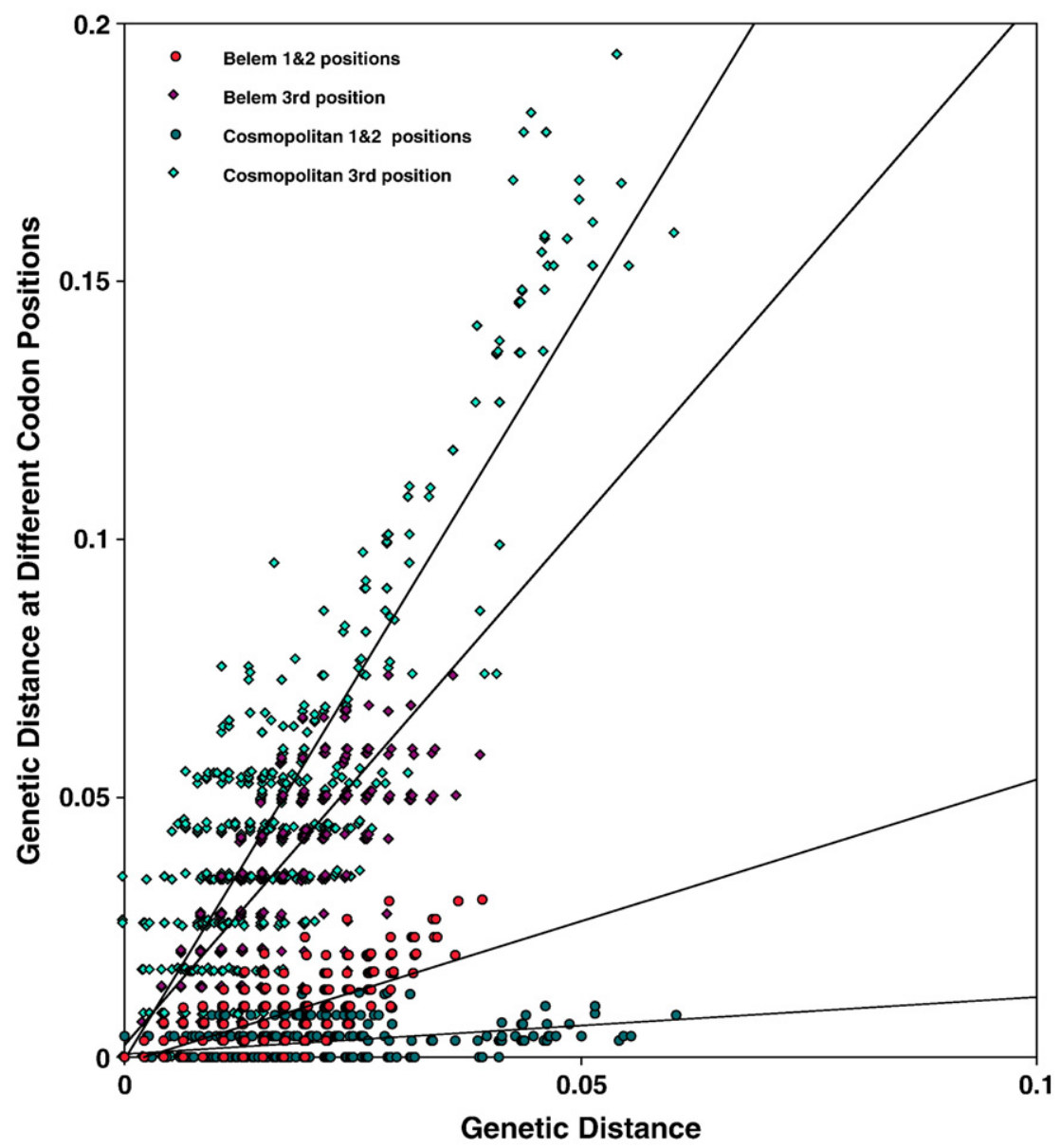

Fig. 2. Plot comparing genetic distances at 1 st and 2 nd with 3 rd codon positions versus total distance among common regions of VP1 and VP2 gene of human parvovirus B19. Regression slopes indicated that sequences from Belém had a higher rate of change at 1st and 2nd codon positions compared to the cosmopolitan sequences (i.e., all other sequences not from Belém) but a lower rate of change at 3rd codon position. 


\section{Selection pressures on $B 19$}

To further explore the evolutionary processes acting on B19 in Belém, we estimated values of Tajima's $D$ statistics that tests the null hypothesis of a mutation-drift equilibrium (i.e., of neutral evolution). Negative values of Tajima's $D$ suggest that positive selection may be acting on a population. Again, a strikingly different pattern was observed between Belém and the Cosmopolitan populations: (i) Cosmopolitan isolates, including sequences from Erdman et al. (1996) and those from the University Hospital of São Paulo City, $D=-0.8776$, S.E. $=$ -0.0455 ( 87 sequences, 10 segregating amino acid sites); and (ii) Belém isolates, $D=-4.1684$, S.E. $=-1.6532$ (47 sequences, 24 segregating amino acid sites). The strongly negative $D$ value obtained for the Belém sequences further supports the idea that the increase in genetic diversity at 1 st and 2 nd codon positions is due to a departure from neutral evolution. Similar results were obtained through an analysis of the relative rates of synonymous $\left(d_{\mathrm{S}}\right)$ and nonsynonymous $\left(d_{\mathrm{N}}\right)$ substitution per site. In this case, $d_{\mathrm{N}}$ was 3.9 times greater in Belém $\left(d_{\mathrm{N}}=0.0043 \pm 0.0011\right)$ compared with sequences from elsewhere $\left(d_{\mathrm{N}}=0.0011 \pm\right.$ $0.003)$. However, there was no significant difference in $d_{\mathrm{S}}$ among populations; Cosmopolitan, $d_{\mathrm{S}}=0.0548 \pm 0.0105$ and Belém, $d_{\mathrm{S}}=0.0490 \pm 0.0139$.

We next investigated whether selection pressures acting on different codon sites could be responsible for the difference among the Belém and Cosmopolitan populations. Using the CODEML method, we found no evidence for positive selection at any individual codon in either the Belém or Cosmopolitan data sets (in that neutral models of codon evolution could not be rejected by those more complex models that support positive selection). However, this analysis also indicated that 15 codons in the B19 isolates from Belém had an elevated $d_{\mathrm{N}} / d_{\mathrm{S}}$ ratio, with a mean ratio of 1.50 . Further, six of these sites were detected as being subject to weak positive selection in HyPhy (Bayes factor values $<20$ ) with a mean $d_{\mathrm{N}} / d_{\mathrm{S}}$ ratio of 1.70 . In contrast,
CODEML detected 4 sites in the Cosmopolitan group with an elevated mean $d_{\mathrm{N}} / d_{\mathrm{S}}$ ratio of 2.25 , three of which were also observed in HyPhy, but with a lower mean $d_{\mathrm{N}} / d_{\mathrm{S}}$ ratio of 1.10 . Considered together, the data revealed an elevation in nonsynonymous rates among the B19 lineages sampled from Belém, several of which could possibly be under positive selection, although this latter conclusion will need to be confirmed with a larger sample of sequences. Moreover, it remains to be determined if similar results of higher nonsynonymous rates among samples from Belém are also to be found in the entire VP1 and VP2 genes, where immune-dominant epitopes are known to be present.

Fig. 1 depicts the most parsimonious reconstructions (MPRs) on the MAP tree, showing the excess of nonsynonymous changes along the independent radiation of lineages in Belém. Sites 4, 27, 72 and 105 changed independently within the Belém clusters, while site 155 was shared by a group of 3 sequences, suggestive of possible propagation among the human population. A single site coding a lysine at codon 19 (shown in yellow in Fig. 1) was shared by both Belém (once) and Cosmopolitan (twice) sequences. Other than codon 19, no other sites in the Cosmopolitan sequences appeared more than once.

\section{Population dynamics of B19}

To investigate other aspects of the population dynamics of B19 in the Belém and Cosmopolitan populations, we estimated several population parameters using the Bayesian coalescent method available in the BEAST package. This analysis revealed that B19 appears to experience equivalent evolutionary rates in all populations, growing according to a logistic model, with similar growth rates and doubling times $(\lambda)$ (Table 1$)$. For all groups, rates of nucleotide substitution exhibited overlapping HPD values, with an average rate of $2.572 \times 10^{-4}$ nucleotide substitutions per site, per year (subs/site/year) for the Belém lineages, of $1.9 \times 10^{-4}$ subs/site/year for the Cosmopolitan

Table 1

Bayesian estimates of population dynamic and evolutionary parameters for B19 in samples from around the world (Cosmopolitan), Belém (Amazon) and the city of São Paulo

\begin{tabular}{|c|c|c|c|}
\hline & Cosmopolitan & Belém & São Paulo \\
\hline Sample size & 39 & 46 & 48 \\
\hline Date range & $1973-2003$ & $1995-2005$ & 1990-2003 \\
\hline Best-fit demographic model & Logistic & Logistic & Logistic \\
\hline Mean $k^{\mathrm{a}}$ & $2.884 \mathrm{e}-4$ & $2.572 \mathrm{e}-4$ & $8.809 \mathrm{e}-5$ \\
\hline \multirow[t]{2}{*}{$95 \% \mathrm{HPD}^{\mathrm{b}} \mathrm{k}$} & Lower $=2.224 \mathrm{e}-5$ & Lower $=7.467 \mathrm{e}-5$ & Lower $=2.683 e-5$ \\
\hline & Upper $=5.641 \mathrm{e}-4$ & Upper $=4.507 \mathrm{e}-4$ & Upper $=1.681 \mathrm{e}-5$ \\
\hline $95 \%$ mean age (years) & 66.5 & 45.104 & 73.223 \\
\hline \multirow[t]{2}{*}{ 95\% HPD age (years) } & Lower $=30$ & Lower $=17.756$ & Lower $=23.918$ \\
\hline & Upper $=166.093$ & Upper $=89.528$ & Upper $=143.451$ \\
\hline Mean growth rate ${ }^{\mathrm{c}}$ & 0.353 & 0.186 & $7.168 \mathrm{e}-2$ \\
\hline \multirow[t]{2}{*}{$95 \%$ HPD growth rate } & Lower $=4.749 \mathrm{e}-3$ & Lower $=3.021 \mathrm{e}-4$ & Lower $=1.053 \mathrm{e}-5$ \\
\hline & Upper $=0.887$ & Upper $=0.405$ & Upper $=0.193$ \\
\hline Mean epidemic doubling time $(l)$ in years & 1.9636 & 3.7266 & 9.6700 \\
\hline \multirow[t]{2}{*}{$95 \%$ HPD doubling time $(l)$ in years } & Lower $=145.95$ & Lower $=2294.43$ & Lower $=65,825$ \\
\hline & Upper $=0.7814$ & Upper $=1.7115$ & Upper $=3.59$ \\
\hline
\end{tabular}

\footnotetext{
${ }^{\text {a }}$ Rate of nucleotide substitution per site, per year.

b $\mathrm{HPD}=$ high probability density.

c Number of new infections per individual, per year.
} 
isolates, and of $8.809 \times 10^{-5}$ subs/site/year for the São Paulo viruses. These results are similar to those estimated previously for B19 (Shackelton and Holmes, 2006).

The most striking result of this analysis is that those B19 lineages independently introduced into Belém have all experienced an elevated rate of nonsynonymous evolution. Since we did not find any features of viral epidemiological dynamics (i.e., population growth rates) consistent with this pattern, we argue that unique differences in the host population, particularly in terms of selection pressure, represent the most likely explanation.

The prevalence of B19 in South America may be around 50\% (Abarca et al., 2002; Anderson et al., 1986; Cohen and Buckley, 1988; Gay et al., 1994; Nunoue et al., 1985), which are close to those obtained globally. B19 is endemic in the Amazon region and may undergo fluctuations in incidence in intervals ranging from 3 to 5 years (Freitas et al., 1993). More notably, there was an increase in prevalence from $43 \%$ in 1990 to $85 \%$ in 2002 in Belém (Freitas et al., 2002). Consequently, the current prevalence in Belém is roughly $70 \%$ higher than in other regions. The clinical resolution of acute B19 infection is associated with the emergence of persistent antiviral $\mathrm{IgG}$, mainly directed to both B19 structural proteins, VP1 and VP2 (Azzi et al., 2004; Rosenfeld et al., 1994). In addition, B19 infection induces a persistent activated $\mathrm{CD}^{+} \mathrm{T}$ cell response (Isa et al., 2005). Both the presence of previous IgG and a strong CTL may play a significant role upon reinfection in immunecompetent individuals (Nikkari et al., 1996; Zakrzewska et al., 2001), and B19 has been shown to reinfect and persist in immune-compromised patients (Flunker et al., 1998). Therefore, a plausible evolutionary scenario for B19 in the Amazon would entail the reintroduction of viral lineages, which must then negotiate, by way of adaptive evolution, higher levels of herd immunity; in other words there is an increased necessity to infect, and reinfect, a small susceptible population. Under this type of selective pressure, B19 lineages present in Belém would show an increase in the number of nonsynonymous changes through adaptive evolution to facilitate serial re-infections. Further, since the host population in the Amazon is smaller than that of other regions providing it with new B19 lineages, a relatively small web of transmission would prevent genetic diversity from accumulating at synonymous positions following repeated selective sweeps (and reflected in measures of genetic diversity at 1 st and 2 nd codon positions). Hence, we propose that Belém acts as an evolutionary "pressure pan" for $\mathrm{B} 19$. It is clearly important to determine whether B19 is under similar pressures in other regions of the world possessing epidemiological conditions similar to those of Belém, or if other endemic pathogens in the Amazon exhibit similar evolutionary patterns.

\section{Materials and methods}

\section{Clinical samples}

The clinical samples used in this study were collected by the Department of Virology, Evandro Chagas Institute, Belém
( $n=46)$ between 1995 and 2005, and at the University of São Paulo Hospital and several other hospitals in the city $(n=48)$ between 1990 and 2003. Blood samples were collected during acute phase of disease by antecubital venepuncture. We included patients diagnosed with: (i) exanthematous diseases, (ii) acute arthropathy, (iii) hematological disorders, (iv) encephalitis, (v) myocarditis and, (vi) systemic lupus erythematosus. All sera were frozen at $-20{ }^{\circ} \mathrm{C}$ until processed anonymously upon the approval by an ethics committee at both, Evandro Chagas Institute and University of São Paulo (Resolução No. 196, 1996).

\section{DNA extraction, PCR and semi-nested PCR}

Viral DNA was extracted from sera samples by the phenolchloroform method (Umene and Nunoue, 1993). The PCR and semi-nested PCR was performed according to Durigon et al. (1993). The expected molecular size was 563 and $476 \mathrm{bp}$ for the first and semi-nested PCR, respectively.

\section{Sequencing}

The nucleotide sequences of the amplified fragment were determined by the dideoxy chain termination method using the sequencing ABI PRISM Dye Terminator kit (Applied Biosystems, Foster City, CA) and resolved in an ABI 3100 DNA sequencer. Both complementary strands were directly sequenced using the same primers used in semi-nested PCR.

\section{Sequences used in this study}

As well as the sequences newly generated here (with GenBank accession numbers in parenthesis) (EF089178, EF089179, EF089180, EF089181, EF089182, EF089183, EF089184, EF089185, EF089186, EF089187, EF089188, EF089189, EF089190, EF089191, EF089192, EF089193, EF089194, EF089195, EF089196, EF089198, EF089199, EF089200, EF089201, EF089202, EF089203, EF089204, EF089205, EF089206, EF089207, EF089208, EF089209, EF089210, EF089211, EF089212, EF089213, EF089214, EF089215, EF089216, EF089217, EF089218, EF089219, EF089220, EF089221, EF089222, EF089223, EF089224, EF154284, EF154285, EF154286, EF154287, EF154288, EF154289, EF154290, EF154291, EF154292, EF154293, EF154294, EF154295, EF154296, EF154297, EF154298, EF154299, EF154300, EF154301, EF154302, EF154303, EF154304, EF154306, EF154308, EF154309, EF154310, EF154311, EF154312, EF154313, EF154314, EF154315, EF154316, EF154317, EF154318, EF154319, EF154320, EF154321, EF154322, EF154324, EF154325, EF154326, EF154327, EF154328, EF154329, EF154330, EF154331, EF154332, EF154333, EF491000), we collected a number of reference sequences from GenBank to expand the scope of our study. These latter sequences had following accession numbers: U31358, U38506, U38507, U38509, U38510, U38511, U38512, U38513, U38514, U38515, U38516, U38517, U38518, U38546, U53600, AB030673, AB030693, 
AB030694, AB126262, AB126263, AB126264, AB126265, AB126267, AB126268, AB126271, AF162273, AF161223, AF161224, AF161225, AF161226, AY386330, AY028237, M24682, M13178, Z68146, Z70560, Z70528, Z70599, NC000883. A number of outgroup sequences were also utilized; genotype 2 (AY044266, AY064475), genotype 3 (AY083234, NC004295) and the Simian parvovirus (U26342). This represented a total of 44 sequences additional sequences. Therefore, a total of 138 sequences were compiled for analysis.

\section{Evolutionary analysis}

To compare B19 from different regions we inferred maximum likelihood (ML) phylogenetic trees using PAUP* (Swofford, 2003), using the best-fit evolutionary model as determined by Modeltest 3.7 (Posada and Crandall, 1998) which was found to be HKY $+\Gamma$ (with a transition/transversion ratio of 3.213 and a shape parameter, $\alpha$, of 0.493 ). Using this model, pairwise genetic distances were estimated for $1 \mathrm{st}$ and 2 nd codon positions taken together (mostly nonsynonymous changes) and for the 3rd codon position separately (mostly synonymous changes), and plotted against total nucleotide distance.

We used a number of methods to determine the selective pressures acting on B19 virus. First, we obtained pairwise estimates of the value of the Tajima's $D$ statistic, and rates of nonsynonymous $\left(d_{\mathrm{N}}\right)$ and synonymous $\left(d_{\mathrm{S}}\right)$ substitutions per site (ratio $d_{\mathrm{N}} / d_{\mathrm{S}}$ ) using the MEGA v3.1 package (Kumar et al., 2004). For the analysis of $d_{\mathrm{N}} / d_{\mathrm{S}}$ we used the codon-based method of $\mathrm{Li}-\mathrm{Wu}-\mathrm{Luo}$, with standard errors estimated after 1000 bootstrap replicates. We also inferred site-specific $d_{\mathrm{N}}$ and $d_{\mathrm{S}}$ using both the CODEML (Yang, 1997) and HyPhy (Pond et al., 2005) programs. In CODEML we employed models 0 (invariant), 1 (neutral), 2 (negative selection), 3 (positive selection), 7 (ten categories of rates for codon sites) and 8 (eleven categories of rates for codon sites) and with HyPhy we used the "MG94xHKY85x3_4x2_Rates" allowing for rate heterogeneity in the model parameters and 4 categories per rate parameter.

To estimate rates of evolutionary change of B19 in both Brazilian populations we employed the Bayesian-Markov Chain-Monte Carlo (MCMC) method available in the BEAST v1.3 package (Drummond and Rambaut, 2003). Sequences were dated according to the year of sampling and run with a chain length of 40 million under the HKY $+\Gamma$ substitution model, under the assumption of a relaxed molecular clock and a variety of different models of demographic history; constant population size, exponential population growth, logistic growth, expansion growth, and a Bayesian skyline plot which gives a piece-wise graphical picture of demographic history. Only the parameters for the best model (i.e., the one showing the maximum a posteriori probability) are shown here. Confidence intervals were given by the $95 \%$ highest probability density (HPD). The BEAST analysis was also used to infer the maximum a posteriori (MAP) tree, which branch-lengths scaled in time. Finally, the most parsimonious reconstructions (MPR) of amino acid changes along lineages of the B19 phylongey were estimated using the MacClade v. 4.07 program (Maddison and Maddison,
2003) using both the ML and MAP trees. MPRs of sites with elevated $d_{\mathrm{N}} / d_{\mathrm{S}}$ were then mapped to specific lineages.

\section{Acknowledgments}

This study was supported by CNPq, MCT and FAPESP projects 00/04205-06 and 00/11511-06-VGDN program. ELD and PMAZ hold a PQ-CNPq scholarship. CMR and FLM hold a CAPES scholarship.

\section{References}

Abarca, K., Cohen, B.J., Vial, P.A., 2002. Seroprevalence of parvovirus B19 in urban Chilean children and young adults, 1990 and 1996. Epidemiol. Infect. $128,59-62$.

Anderson, L.J., Tsou, C., Parker, R.A., Chorba, T.L., Wulf, H., Tattersall, P., Mortimer, P.P., 1986. Detection of antibodies and antigens of human parvovirus B19 by enzyme-linked immunosorbent assay. J. Clin. Microbiol. 24, 522-526.

Azzi, A., Manaresi, E., Zakrzewska, K., DeSantis, R., Musiani, M., Zerbini, M., 2004. Antibody response to B19 parvovirus VP1 and VP2 linear epitopes in patients with haemophilic arthritis. J. Med. Virol. 72, 679-682.

Brown, K.E., Young, N.S., Liu, J.M., 1994. Molecular, cellular and clinical aspects of parvovirus B19 infection. Crit. Rev. Oncol. Hematol. 16 (1), $1-31$.

Cleaveland, S., Laurenson, M.K., Taylor, L.H., 2001. Diseases of humans and their domestic mammals: pathogen characteristics, host range and the risk of emergence. Philos. Trans. R. Soc. Lond., B 356, 991-999.

Cohen, B.J., Buckley, M.M., 1988. The prevalence of antibody to human parvovirus B19 in England and Wales. J. Med. Microbiol. 25, 151-153.

Drummond, A.J., Rambaut, A., 2003. BEAST v1.0, Available from http:// evolve.zoo.ox.ac.uk/beast/.

Durigon, E.L., Erdman, D.D., Gary, G.W., Pallansch, M.A., Torok, T.J., Anderson, L.J., 1993. Multiple primer pairs for polymerase chain reaction (PCR) amplification of human parvovirus B19 DNA. J. Virol. Methods 44, $155-165$.

Erdman, D.D., Durigon, E.L., Wang, Q.Y., Anderson, L.J., 1996. Genetic diversity of human parvovirus B19: sequence analysis of the $V P 1 / V P 2$ gene from multiple isolates. J. Gen. Virol. 77, 2767-2774.

Flunker, G., Peters, A., Wiersbitzky, S., Modrow, S., Seidel, W., 1998. Persistent parvovirus B19 infections in immunocompromised children. Med. Microbiol. Immunol. 186, 189-194.

Freitas, R.B., Miranda, M.F., Shirley, J., Tudor, R., Desselberger, U., Linhares, A.C., 1993. Parvovirus B19 antibodies in sera of patients with unexplained exanthemata from Belem, Para, Brazil. Mem. Inst. Oswaldo Cruz 88, 497-499.

Freitas, R.B., Monteiro, T.A., Silva Filho, M.G., Linhares, A.C., 2002. Association between human parvovirus B19 and arthropathy in Belem, Para, North Brazil. Rev. Inst. Med. Trop. Sao Paulo 44, 17-22.

Gay, N.J., Hesketh, L.M., Cohen, B.J., Rush, M., Bates, C., Morgan-Capner, P., Miller, E., 1994. Age specific antibody prevalence to parvovirus B19: how many women are infected in pregnancy? Commun. Dis. Rep. CDR Rev. 4 (9), R104-R107.

Isa, A., Kasprowicz, V., Norbeck, O., Loughry, A., Jeffery, K., Broliden, K., Klenerman, P., Tolfvenstam, T., Bowness, P., 2005. Prolonged activation of virus-specific $\mathrm{CD}^{+} \mathrm{T}$ cells after acute B19 infection. PLoS Med. 2, e343.

Kumar, S., Tamura, A., Nei, M., 2004. MEGA 3: integrated software for molecular evolutionary genetic analysis and sequence alignment. Brief Bioinform. 5, 150-160.

Maddison, D.R., Maddison, W.P., 2003. MacClade 4: Analysis of Parsimony and Character Evolution, 4.06th edition. Sunderland, Sinauer Associates.

Nikkari, S., Lappalainen, H., Saario, R., Lammintausta, K., Kotilainen, P., 1996. Detection of parvovirus B19 in skin biopsy, serum, and bone marrow of a patient with fever, rash, and polyarthritis followed by pneumonia, pericardial effusion, and hepatitis. Eur. J. Clin. Microbiol. Infect. Dis. 15, 954-957. 
Nunoue, T., Okochi, K., Mortimer, P.P., Cohen, B.J., 1985. Human parvovirus (B19) and erythema infectiosum. J. Pediatr. 107, 38-40.

Pattison, J.R., 1990. The pathogenesis of diseases associated with B19 virus. Behring-Inst.-Mitt. 85, 55-59.

Pond, S.L., Frost, S.D., Muse, S.V., 2005. HyPhy: hypothesis testing using phylogenies. Bioinformatics 21 (5), 676-679.

Posada, D., Crandall, K.A., 1998. Modeltest: testing the model of DNA substitution. Bioinformatics 14, 817-818.

Rosenfeld, S.J., Young, N.S., Alling, D., Ayub, J., Saxinger, C., 1994. Subunit interaction in B19 parvovirus empty capsids. Arch. Virol. 136, 9-18.

Shackelton, L.A., Holmes, E.C., 2006. Phylogenetic evidence for the rapid evolution of human B19 erythrovirus. J. Virol. 80, 3666-3669.

Shackelton, L.A., Parrish, C.R., Truyen, U., Holmes, E.C., 2005. High rate of viral evolution associated with the emergence of carnivore parvovirus. Proc. Natl. Acad. Sci. U.S.A. 102, 379-384.

Swofford, D.L., 2003. PAUP*. Phylogenetic Analysis Using Parsimony (*and Other Methods) Version 4. Sinauer Associates, Sunderland, Massachusetts.

Umene, K., Nunoue, T., 1993. Partial nucleotide sequencing and characterization of human parvovirus B19 genome DNAs from damaged human fetuses and from patients with leukemia. J. Med. Virol. 39, 333-339.

Yang, Z., 1997. PAML: a program package for phylogenetic analysis by maximum likelihood. Comput. Appl. Biosci. 13, 555-556.

Zakrzewska, K., Azzi, A., De Biasi, E., Radossi, P., De Santis, R., Davoli, P.G., Tagariello, G., 2001. Persistence of parvovirus B19 DNA in synovium of patients with haemophilic arthritis. J. Med. Virol. 65, 402-407. 


\section{ANEXO 3:}

FREITAS, R. B.; MELO, F. L.; OLIVEIRA, D. S.; ROMANO, C. M.; FREITAS, M. R. C.; MACÊDO, O.; LINHARES, A. C.; ZANOTTO, P. M. A.; DURIGON, E. L. Molecular characterization of human erythrovirus B19 strains obtained from a variety of clinical conditions in the Amazon region of Brazil. J. Clin.Virol. Submetido, 2008. 


\section{Molecular characterization of human erythrovirus B19 strains obtained from a variety} of clinical conditions in the Amazon region of Brazil

Ronaldo B. Freitas ${ }^{1 *}$, Fernando L Melo², Darleise S. Oliveira ${ }^{1}$, Camila M. Romano ${ }^{2}$, Maria Rute C. Freitas ${ }^{1}$, Olinda Macêdo ${ }^{1}$, Alexandre C. Linhares ${ }^{1}$, Paolo M. de A. Zanotto $^{2}$, Edison Luiz Durigon ${ }^{3}$

${ }^{1}$ Seção de Virologia, Instituto Evandro Chagas, Secretaria de Vigilância em Saúde, Ministério da Saúde, Rodovia BR 316-Km 7, S/N, Levilândia, 67037-000, Ananindeua, Pará, Brazil.

${ }^{2}$ Laboratório de Evolução Molecular e Bioinformática - LEMB, Departamento de Microbiologia, Instituto de Ciências Biomédicas - ICB II, Av Professor Lineu Prestes, 1734, 05508-900, Universidade de São Paulo, São Paulo, Brasil

${ }^{3}$ Laboratório de Virologia Clínica, Departamento de Microbiologia, Instituto de Ciências Biomédicas - ICB II, Av. Professor Lineu Prestes, 1734, 05508-900, Universidade de São Paulo, São Paulo, Brasil.

Corresponding author: $*$ Phone: $+55-91-32142014$, fax: $+55-91-32142005$, e-mail: ronaldofreitas@iec.pa.gov.br 


\begin{abstract}
Background: The human erythrovirus B19 appears to be related to endemic viral activity and to a wide clinical spectrum since 1990 in the Amazon region.

Objectives: To assess the circulation and relative frequency of erythrovirus B19 genotypes in clinical samples from patients living in the Amazon region showing various clinical conditions.
\end{abstract}

Study Design: A total of 487 clinical samples obtained from patients with clinical symptoms suggestive of the erythrovirus infection were tested using specific $\operatorname{IgM}$ and $\operatorname{IgG}$ antibodies assays (ELISA) and PCR for viral DNA detection. Partial VP1 and VP2 regions were sequenced and genotyped by phylogenetic reconstructions.

Results: B19 DNA was detected in 117 (24\%) of 487 samples. Of these, 106 (91\%) isolates were sequenced and genotyped as genotype 1 and $11(9 \%)$ as genotype 3, but no genotype 2 was found. Genotype 1 had three clusters and all genotype 3 sequences were from subtype $3 b$. The remarkable finding was that all patients with hematological disorders within cluster B of genotype 1were infected by the same B19 lineage, suggesting that this lineage of B19 may be experiencing transmission within the blood treatment system.

Conclusion: We reported two genotypes, 1 and $3 \mathrm{~b}$, circulating in the Amazon region and three genotype 1 clusters co-circulating during the past 10 years.

Keywords: Erythrovirus B19; Genotypes 1 and 3; Clinical manifestations; Phylogenetic analysis. 


\section{Introduction}

Human parvovirus B19 has worldwide distribution and causes several clinical illnesses including erythema infectiosum (EI), transient aplastic crisis (TAC), arthritis, persistent anemia in immune compromised patients and hydrops fetalis (Chorba et al., 1986; Caul et al., 1988; Kurtzman et al., 1988; Anderson, 1990; Cubel et al., 1992; Foto et al., 1993; Ueno et al., 1993; Cassinotti et al., 1995; Kajigaya et al., 1997; Koduri et al., 2000; Chisaka et al., 2006). Human erythroviruses are grouped into three distinct genotypes: genotype 1 (B19 strains), genotype 2 (A6 strains) and genotype 3 (V9/D91.1 strains) (Servant et al., 2002). Furthermore, Parsyan et al. (2007) have proposed two distinct subtypes, 3a (V9 related) and 3b (D91.1 related), within the genotype 3. In Brazil, the association of B19 infection with EI was reported 20 years ago (Freitas et al., 1988; Miranda et al., 1989). Early studies in Rio de Janeiro detected B19 in the plasma of healthy blood donors (Cruz et al., 1989). Extensive serological surveys among both urban and remote Amazonian communities revealed a wide range of prevalence rates (Freitas et al., 1990, 1993, 1999, 2002). Herein we describe the circulation of erythrovirus genotypes from patients with distinct clinical conditions in the Amazon region.

\section{Material and Methods}

\subsection{Clinical samples}

Samples were obtained in the Brazilian Amazon, between January 1995 and December 2005. A total of 487 blood samples were collected from individuals suffering from: (i) exanthematous illnesses (group I [ $\mathrm{n}=207])$, (ii) hematological disorders (group II [ $\mathrm{n}=188]$ ), (iii) arthropathy (group III $[\mathrm{n}=67]$ ) and (iv) B19-associated novel clinical conditions including encephalitis, hepatitis, myocaditis and systemic lupus erythematosus (group IV [n = 25]). Of the 487 individuals, 197 were male. The age of patients ranged from one month to 
eighty years (median age, $18 \pm 11$ years). Blood samples were collected and stored according to Freitas et al. (2007), following procedures and the approval by the ethical review boards from IEC and the University of São Paulo (CEPSH-ICB-USP).

\subsection{Sorological assay}

Detection of IgM- and- IgG- specific antibodies to erythrovirus B19 were performed using a commercial enzyme immune-assay manufactured by Biotrin ${ }^{\mathrm{TM}}$, Dublin, Ireland, according to the manufacturer's instructions.

\subsection{PCR detection and Sequencing}

The partial VP1/VP2 region from B19 genome was amplified as reported by Durigon et al. (1993). The sequencing reactions were done using Big Dye Terminator Cycle Sequencing Ready Reaction Kit on an ABI 3100 automated DNA sequencer (Applied Biosystems, Inc., Foster City, CA).

\subsection{Phylogenetic analysis}

The sequences were aligned using the BioEdit Editor version 7.0.5.2 (Hall, 2004). Maximum likelihood (ML) phylogenetic tree was generated using PAUP* v4.0b10 (Swofford, 2003), by the tree bisection-reconnection (TBR), subtree pruning regrafting (SPR) and the nearestneighbor interchange (NNI) heuristic methods. The $\mathrm{HKY}+\Gamma$ was the substitution model used as the best fitted by Modeltest 3.7 (Posada and Crandall, 1998). The same model was also used to estimate maximum a posteriori (MAP) trees using a Bayesian Markov Chain Monte Carlo method (MCMC) available in the BEAST v1.6 package, with chain length of 40 million (Drummond and Rambaut, 2007). The MCMC method was also used to estimate the time of introduction of genotype 3 into the Amazon region, under the assumption of a relaxed molecular clock and a variety of different models of demographic history: constant population 
size, exponential population growth, logistic growth, expansion growth, and a Bayesian skyline plot. The sampling dates for the reference sequences were obtained from Parsyan et al. (2007).

We used a total of 117 sequence generated here (GenBank under accession numbers EF089178-EF089196, EF089198-EF089232 and EU142742-EU142804), including a previously published dataset with 46 sequences from genotype 1 from Belém (Freitas et al., 2007). The reference sequences had following accession numbers: Genotype 1 (U31358, U38507, U38509, U38510, U38515, U38546, U53600, AB030673, AB126271, AF161224, AF162273, AY386330, AY028237, M13178 and Z70528); Genotype 2 (AY044266, AY044268, AY064476 and AY064475); Genotype 3a (DQ234769, DQ234771, AY582125 and NC_O04295); Genotype 3b (AY083234, AY582124, AY647977, DQ234779 and DQ234778). Therefore, a total of 145 sequences were compiled for analysis

\section{Results}

Of the 487 samples examined by serological assay, PCR and genotyping, 363 (74.5\%) were B19-antibody-positive and 124 (25.5\%) were antibody-negative (Table 1). Erythrovirus DNA was identified and sequenced from $117(24 \%)$ of these samples. Of the 117 isolates genotyped, 107 (91\%) had IgM antibodies; 3 (2.6\%) had IgG antibodies only; and 7 (6\%) had neither IgM nor IgG antibodies. In the group I, $53(45.3 \%)^{\mathrm{a}}$ genotype 1 strains were collected from individuals $\leq 15$ years; $9(7.7 \%)^{\mathrm{b}}$ among those aged $>15$ years $(\mathrm{a} v s$ b, $\mathrm{p}<0.0001)$ and 6 (5\%) genotype 3 strains were found in individuals with $\leq 15$ years. In the group III, two $(1.7 \%)^{\mathrm{c}}$ genotype 1 samples were found in individuals aged $\leq 15$ years; $10(8.5 \%)^{\mathrm{d}}$ were from those aged $>15$ years $(\mathrm{c} v s \mathrm{~d}, \mathrm{p}<0.001)$ and $2(1.7 \%)$ genotype 3 strains were sampled from individuals $>15$ years. 
The maximum likelihood tree agreed with the maximum a posteriori (MAP) tree estimated with BEAST (Figure 1), where 106 (91\%) of 117 isolates clustered within genotype 1 and eleven (9\%) clustered into genotype 3. Genotype 1 sequences included three distinct clusters (A1, A2 and B). Cluster A1 included 37 cases of exanthematous illnesses (EI), 13 cases of hematological disorders (HD) and 7 cases of arthropathy (AP). In cluster A2 we had 19 EI, 6 HD and 3 AP cases. Cluster B included 7 EI, 11 HD and 2 AP cases and one case of myocarditis (MC). In addition, genotype 3 there was one case of systemic lupus erythematous (LE), $6 \mathrm{EI}, 1 \mathrm{HD}$ and $1 \mathrm{AP}$. In cluster B, 52\% (i.e., eleven of twenty one) of the patients had HD. Crucially, the HD in cluster B significantly higher $\chi^{2}=7.48, p<0.006$ ) compared with HD in clusters A1 and A2.

Both evolutionary rate and dates of divergence for genotype 3 were shown in Table 2 . The best-fit model indicted a logistic population growth and the mean rate of nucleotide substitution was $1.2 \times 10^{-3}$ (95\% HPD of $3.10 \times 10^{-4}$ to $2.32 \times 10^{-3}$ ). Given this rate, the most recent common ancestor (MRCA) (i.e., the time of the oldest node in the tree, indicating the age of the descendent lineage) for all sequences from genotype 3 was thirty-six years (95\% HPD of 14 to 52 years). The mean time of origin of both subtypes $3 \mathrm{a}$ and $3 \mathrm{~b}$ were 21 (95\% HPD of 10 to 41 years) and 28 (95\% HPD of 14 to 49 years), respectively. The MRCA for genotype $3 b$ in Belém was 19 years (95\% HPD of 9 to 38 years).

\section{Discussion}

Until now, a limited number of studies reported the presence of erythrovirus genotype 1 (B19type virus) and 3 (V9 and D91.1-related strains) in temperate and tropical countries (Heegaard et al., 2001; Servant et al., 2002; Sanabani et al., 2006; Toan et al., 2006). This is the first report on the presence of distinct genotypes in the Amazon region. The predominance of genotype 1 (B19) (91\%) and relative low frequency of genotype $3(9 \%)$ were similar to those 
previously found in Vietnam (Toan et al., 2006) and France (Servant et al., 2002). The high frequency of genotype 1 could be explained by the earlier introduction of B19-type virus lineages in the Amazon region, around 45 years ago (Freitas et al., 2007). Interestingly our data suggested a recent introduction of the D91.1 variant of genotype 3, in the Amazon (19 years ago) compared with its presence in the rest of the world with a MRCA at 36 years in the past.

Sequences from genotypes 1 and $3 \mathrm{~b}$ had average genetic diversities of $1.1 \%$ and $0.8 \%$ respectively, and diverged $12.8 \%$ between genotypes. These values are consistent with those previously described for these genotypes when analyzing the same region of VP1/VP2 gene (Servant et al., 2002; Toan et al., 2006; Parsyan, et al., 2007). The mean substitution rate of $1.2 \times 10^{-3}$ nucleotide substitution/site/year, found for genotype 3 strains was higher than those previously reported for genotypes 1 (Shackelton and Holmes, 2006; Freitas et al., 2007) and 3 (Parsyan et al., 2007). Using this rate, the MRCA for genotype 3 was dated at 36 years ago (95\% HPD of 14 to 52 years). Our results differ considerably (one order of magnitude) from estimates of MRCA at 525 years ago (Parsyan et al., 2007). However, the 95\% HPD values of this estimate were extremely large (95\% HPD of 43.5 to 1992 years) and overlapped with our estimate (95\% HPD of 14 to 52 years). Furthermore, it appears that the introduction of genotype $3 b$ into the Amazon region occurred recently (19 years ago, 95\% HPD of 9 to 38 years). The mean genetic divergence of $0.8 \%$ within the Amazon $3 b$ sequences was consistent with a single recent introduction and it is almost three times lower than that of subtype B19/3a in Ghana (2.72\%) (Parsyan et al., 2007).

We observed a higher frequency of genotype 1 associated with EI in children (45.3\%) than adults $(7.6 \%)(\mathrm{p}<0.0001)$, which was similar to Vietnam (Toan et al., 2006). However, in AP patients, genotype 1 was more frequent in adults (8.5\%), compared to children $(1.7 \%)$ $(\mathrm{p}<0.001)$. Similar age structuring was observed for HD patients (children, 13.7\% and adults, 
$12.8 \%$ ). On the other hand, genotype 3 was associated with both, a wider range of clinical manifestations and an uneven distribution within clinical groups, showing higher frequency among children with EI (5\%), similar to what has previously been observed by Servant et al. (2002). Noticeably, only one adult infected with genotype 3 had HD. In this case there was an apparent difference between our results and previous studies reporting a higher frequency of genotype 3 in adult patients with hematological symptoms (Nguyen et al., 1999; Servant et al., 2002; Sanabani et al. 2006). In genotype 1, we found three different clusters (A1, A2 and B) with elevated rates of non-synonymous substitutions after being independently introduced in the Amazon region (Freitas et al., 2007). Interestingly, genotype 1 was more frequently related with women in three of the four clinical groups (data not shown), corroborating previous findings from patients with AP in the Amazon (Freitas et al., 2002). Moreover, we observed a statistical significant proportion $\left(\chi^{2}=7.48, \mathrm{p}<0.006\right)$ of patients with HD within cluster B, which contrasted with clusters A1 and A2. Crucially, all samples from cluster B, involving HD patients, came from the local blood bank and the majority was collected between 2004 and 2005. Moreover, the basal lineage of cluster B was isolated from a patient under blood therapy in Rio de Janeiro in 1988, indicating that possibly Cluster B viruses have a long history of association with blood therapy. These worrisome findings beg investigating if HD patients might be experiencing infection from the same B19 lineage (cluster B). It needs to be pointed out that the Brazilian health system has no routine screening for B19 in blood banks and B19 can be transmitted by blood products (Beersma et al., 2005).

In sum, we found two genotypes, 1 and $3 b$, circulating in the Amazon region of Brazil and tree genotype 1 clusters co-circulating during the past 10 years. Further studies are needed to monitor the occurrence of erythrovirus genotypes in the Amazon region and the possible introduction of genotype 2. We believe that our data has to be taken as a 
warning by the Brazilian Health System towards the inclusion of B19 screening in blood banks. Other than the primary respiratory route of transmission, our findings lead to the hypothesis that B19 may be experiencing sustained transmission in time through the administration of blood products to susceptible patients. 


\section{References}

Anderson LJ. Human parvoviruses. J Infect Dis 1990;161:603-8.

Beersma MF, Claas EC, Sopaheluakan T, Kroes AC. Parvovirus B19 viral loads in relation to VP1 and VP2 antibody responses in diagnostic blood samples. J Clin Virol 2005;34:71-5.

Cassinotti P, Bas S, Siegl G, Vischer TL Association between human parvovirus B19 infection and arthritis. Ann Rheum Dis 1995;54:498-500.

Caul EO, Usher MJ, Burton PA. Intrauterine infection with human parvovirus B19: a light and electron microscopy study. J Med Virol 1988;24:55-66.

Chisaka H, Ito K, Niikura H, Sugawara J, Takano T, Murakami T, Terada Y, Okumura K, Shiroishi H, Sugamura K, Yaegashi N. Clinical manifestations and outcomes of parvovirus B19 infection during pregnancy in Japan Tohoku J Exp Med 2006; 209:27783.

Chorba T, Coccia P, Holman RC, Tattersall P, Anderson LJ, Sudman J, Young NS, Kurczynski E, Saarinen UM, Moir R . The role of parvovirus B19 in aplastic crisis and erythema infectiosum (fifth disease). J Infect Dis 1986;154:383-93.

Cruz AS, Serpa MJA, Barth OM, Nascimento JP. Detection of the human parvovirus B19 in blood donor plasma in Rio de Janeiro. Mem Inst Oswaldo Cruz 1989; 84:279-280.

Cubel RCN, Valadão MC, Pereira WV, Magalhães MC, Nascimento JP. Aplastic crisis due to human parvovirus B19 infection in hereditary hemolytic anaemia. Rev Inst Med Trop São Paulo 1992;34: 479-82.

Drummond AJ, Rambaut A. BEAST: Bayesian evolutionary analysis by sampling trees. BMC Evol Biol 2007: 7:214.

Durigon EL, Erdman DD, Gary WG, Pallansch MA, Torok TJ, Anderson LJ. Multiple primer pairs for polymerase chain reaction (PCR) amplification of human parvovirus B19 DNA. J Virol Methods 1993;44:155-65. 
Erdman DD, Durigon EL, Wang QY, Anderson LJ. Genetic diversity of human parvovirus B19: sequence analysis of the VP1VP2 gene from multiple isolates. J. Gen Virol 1996;77:2767-74.

Foto F, Saag KG, Scharosch LL, Howard EJ, Naides SJ. Parvovirus B19 - specific DNA in bone marrow from B19 arthropathy patients: evidence for B19 virus persistence. J Infect Dis 1993;167:744-8.

Freitas RB, de Miranda MF, Shirley J, Tudor R, Desselberger U, Linhares AC. Parvovirus B19 antibodies in sera of patients with unexplained exanthemata from Belém, Pará, Brazil. Mem Inst Oswaldo Cruz 1993;88:497-9.

Freitas RB, Durigon EL, Oliveira DS, Romano CM, de Freitas MR, Linhares AC, Melo FL, Walshkeller L, Borbosa ML, Huatuco EM, Holmes EC, Zanotto PM. The "pressure pan” evolution of human erythrovirus B19 in the Amazon, Brazil. Virology 2007 (in press).

Freitas RB, Gusmão SRB, Durigon EL, Linhares, AC. Survey of parvovirus B19 infection in a cohort of pregnant women in Belém, Brazil. Braz J Infect Dis 1999;3:6-14.

Freitas RB, Linhares AC, Miranda MFR, Gabbay YB. Novo agente de doença exantemática na Amazônia: O parvovirus “B19”. Bol Epidemiol 1988;20:1-4.

Freitas RB, Monteiro TA, Silva Filho MG, Linhares AC. Association between human parvovirus B19 and arthropathy in Belém, Pará, North Brazil. Rev Inst Med Trop São Paulo 2002;44:17-22.

Freitas RB, Wong D, Boswel F, Miranda MFR, Linhares AC, Shirley J, Desselberger U. Prevalence of Human Parvovirus (B19) and rubellavirus infections in urban and remote rural areas in Northern Brazil. J Med Virol 1990;32:203-8.

Hall T: BioEdit. Biological sequence alignment editor for Windows. [http://www. mbio.ncsu.edu/BioEdit/bioedit.html] North Carolina State University, NC, USA; 2004. 
Heegaard, ED, Panum Jensen I, Christensen J. Novel PCR Assay for Differential Detection and Screening of Erythrovirus B19 and Erythrovirus V9. J Med Virol 2001; 65:362-7.

Kajigaya S, Momoeda M. Immune response to B19 infection In: Anderson LJ, Young N. S, editors. Human parvovirus B19. 1st ed; vol. 20. Karger, New York, N. Y. 1997; 12136.

Koduri PR Parvovirus B19-related anemia in HIV-infected patients. AIDS Patient Care and STDS 2000;14:7-11.

Kumar S, Tamura A, Nei M. MEGA 3: Integrated software for molecular evolutionary genetic analysis and sequence alignment. Brief Bioinform 2004;5:150-60.

Kurtzman GJ, Cohen B, Meyers P, Amunullah A, Young NS. Persistent B19 parvovirus infection as a cause of severe chronic anaemia in children with acute lymphocytic leukaemia. Lancet 1988;2:159-62.

Miranda MFR, Linhares AC, Shirley JA Fifth disease in children living in Belém, Brasil. Rev Inst Med Trop S Paulo 1989;31:359-62.

Nguyen QT, Sifer C, Schneider V, Allaume X, Servant A, Bernandin F, Auguste V, GarbargChenon, A Novel human erythrovirus associated with transient aplastic anemia. J Clin Microbiol 1999;37:2483-7.

Nguyen QT, Wong S, Heegaard ED, Brown KE Identification and characterization of a second novel human erythrovirus variant, A6. Virology 2002;301:374-80.

Parsyan A, Szmaragd C, Allain JP, Candotti D. Identification and genetic diversity of two human parvovirus B19 genotype 3 subtypes. J Gen Virol 2007;88:428-31.

Posada D, Crandall KA. Modeltest: testing the model of DNA substitution Bioinformatics. $1998 ; 14: 817-818$. 
Sanabani S, Neto WK, Pereira J, Sabino EC. Sequence variability of human erythroviruses present in bone marrow of Brazilian patients with various parvovirus B19-related hematological symptoms. J Clin Microbiol 2006;44:604-6.

Shackleton LA, Holmes EC. Phylogenetic evidence for the rapid evolution of human B19 erythrovirus. J Virol 2006; 80:3666-69.

Shackleton LA, Parrish CR, Truyen U, Holmes EC. High rate of viral evolution associated with the emergence of carnivore parvovirus. Proc Natl Acad Sci USA 2005; 102:379-84.

Servant A, Laperche S, Lallemand F, Marinho V, De Saint Maur G, Meritet JF, GarbargChenon A. Genetic diversity within human erythrovirus: identification of three genotypes. J Virol 2002;76:9124-34.

Swofford DL: PAUP*. Phylogenetic Analysis Using Parsimony (*and other methods) Version 4. Sinauer Associates, Sunderland, Massachusetts; 2003.

Toan NL, Duechting A, Kremsner PG, Song le H, Ebinger M, Aberle S, Binh VQ, Duy DN, Torresi J, Kandolf R, Bock CT. Phylogenetic analysis of human parvovirus B19, indicating two subgroups of genotype 1 in Vietnamese patients. J Gen Virol 2006; $87: 2941-9$

Ueno Y, Umadome H, Shimodera M, Kishimoto I, Ikegaya K, Yamauchi T. Human parvovirus B19 and arthritis. Lancet 1993;341:1280. 
Table 1. Clinical features and laboratory results from patients infected with erythrovirus in the Amazon region, 1995 - 2005. 


\begin{tabular}{|c|c|c|c|c|c|c|c|c|c|c|c|c|c|}
\hline \multirow[b]{3}{*}{$\begin{array}{c}\text { Clinical } \\
\text { group }\end{array}$} & \multirow[b]{3}{*}{$\begin{array}{c}\text { Age } \\
\text { group }\end{array}$} & \multicolumn{9}{|c|}{ Serological status/DNA detection/Genotype } & \multirow{3}{*}{$\begin{array}{c}\begin{array}{c}\text { Total } \\
(\mathrm{N}=487)\end{array} \\
\text { DNA }^{+}\end{array}$} & \multirow{2}{*}{\multicolumn{2}{|c|}{$\begin{array}{c}\text { Total } \\
(\mathrm{N}=117)\end{array}$}} \\
\hline & & \multicolumn{3}{|c|}{$\operatorname{IgM}^{+}$} & \multicolumn{3}{|c|}{ IgG $^{+}$only } & \multicolumn{3}{|c|}{$\operatorname{IgM}^{-} / \mathbf{I g G}^{-}$} & & & \\
\hline & & DNA $^{+}$ & G1 & G3 & DNA $^{+}$ & G1 & G3 & DNA $^{+}$ & G1 & G3 & & G1 & G3 \\
\hline \multirow{2}{*}{ I } & $\leq 15$ & 54 & 48 & 6 & 1 & 1 & 0 & 4 & 4 & 0 & 59 & $53(45.3 \%)^{\mathrm{a}}$ & $6(5 \%)$ \\
\hline & $>15$ & 8 & 8 & 0 & 0 & 0 & 0 & 1 & 1 & 0 & 9 & $9(7.7 \%)^{b}$ & $0(0 \%)$ \\
\hline \multirow{2}{*}{ II } & $\leq 15$ & 13 & 13 & 0 & 2 & 2 & 0 & 2 & 1 & 1 & 17 & $16(13.7 \%)$ & $1(0.8 \%)$ \\
\hline & $>15$ & 16 & 15 & 1 & 0 & 0 & 0 & 0 & 0 & 0 & 16 & $15(12.8 \%)$ & $1(0.8 \%)$ \\
\hline \multirow{2}{*}{ III } & $\leq 15$ & 4 & 2 & 2 & 0 & 0 & 0 & 0 & 0 & 0 & 4 & $2(1.7 \%)^{\mathrm{c}}$ & $2(1.7 \%)$ \\
\hline & $>15$ & 10 & 10 & 0 & 0 & 0 & 0 & 0 & 0 & 0 & 10 & $10(8.5 \%)^{\mathrm{d}}$ & $0(0 \%)$ \\
\hline \multirow{2}{*}{ IV } & $\leq 15$ & 2 & 1 & 1 & 0 & 0 & 0 & 0 & 0 & 0 & 2 & $1(0.8 \%)$ & $1(0.8 \%)$ \\
\hline & $>15$ & 0 & 0 & 0 & 0 & 0 & 0 & 0 & 0 & 0 & 0 & $0(0 \%)$ & $0(0 \%)$ \\
\hline Total & & 107 & 97 & 10 & 3 & 3 & $\mathbf{0}$ & 7 & 6 & 1 & $117(24 \%)$ & $106(91 \%)$ & $11(9 \%)$ \\
\hline
\end{tabular}

I = exantemous illness; II = hematological disorders; III = arthropathy; IV = others clinical conditions; G1 = genotype 1; $\mathrm{G} 3=$ genotype 3; a $v s \mathrm{~b}=\mathrm{p}<0.0001 ; \mathrm{c} v s \mathrm{~d}=\mathrm{p}<0.001$. 
Table 2. Bayesian estimates of population dynamics and evolutionary parameters for the VP1/VP2 region of human erythrovirus D91.1 (genotype 3). 


\begin{tabular}{|c|c|c|c|c|}
\hline & \multicolumn{4}{|c|}{ Genotype } \\
\hline & All 3 & $\mathbf{3 a}$ & 3b all & 3b Belém \\
\hline $\mathrm{N}^{\mathrm{o}}$ of samples & 21 & 5 & 16 & 11 \\
\hline Range of sample collection & $1991-2005$ & $1995-2005$ & 1991-2004 & $1997-2003$ \\
\hline Molecular Clock type & Relaxed & NA & NA & NA \\
\hline Best-fit demographic model & Logistic growth & NA & NA & NA \\
\hline Substitution rate ${ }^{\mathrm{a}}\left(95 \% \mathrm{HPD}^{\mathrm{b}}\right)$ & $\begin{array}{l}1.2 \times 10^{-3}\left(3.1 \times 10^{-4} \text { to }\right. \\
\left.2.32 \times 10^{-3}\right)\end{array}$ & NA & NA & NA \\
\hline $\begin{array}{l}\text { Mean age (years) of } \mathrm{MRCA}^{\mathrm{c}}(95 \% \\
\text { HPD) }\end{array}$ & $36(14-52)$ & $21(10-41)$ & $28(14-49)$ & $19(9-38)$ \\
\hline $\begin{array}{l}\text { Mean rate of population growth }{ }^{\mathrm{d}} \\
\text { (95\% HPD) }\end{array}$ & $3.89\left(1.034 \times 10^{-4}\right.$ to 9.228$)$ & NA & NA & NA \\
\hline $\begin{array}{l}\text { Mean epidemic doubling time }(\lambda)^{\mathrm{e}} \\
\text { (years) }\end{array}$ & 5.44 & NA & NA & NA \\
\hline
\end{tabular}

${ }^{\mathrm{a}}$ Mean number of nucleotide substitutions per site, per year.

${ }^{b}$ High probability density.

${ }^{\mathrm{c}}$ MRCA, most recent common ancestor.

${ }^{\mathrm{d}}$ Mean number of new infections per host, per year.

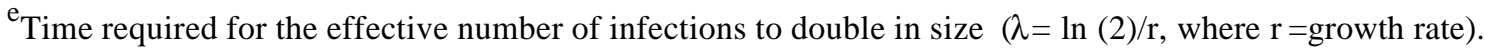
NA, Not applicable. 
Figure 1. Maximum a posteriori tree (MAP tree) of partial region (476bp) of B19 virus VP1/VP2 region, obtained of 117 patients from North region of Brazil, from January/1995 to October/2005. Prototypes of the three B19 genotypes were presented in the tree, together with strains from other places. Posterior values are specified on the nodes. Scale bar is proportional to the genetic distance. 


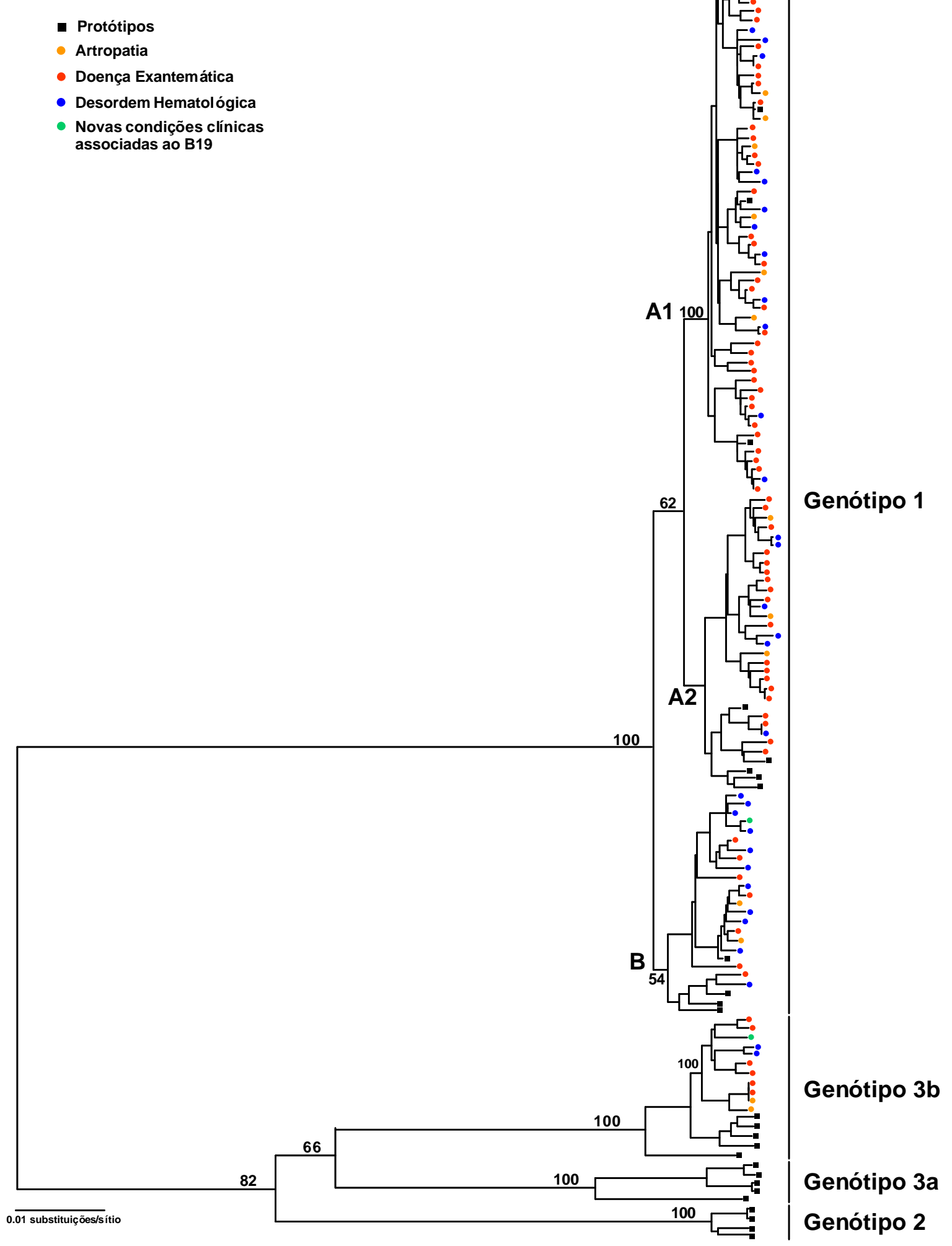

